Ana de Oliveira DiAs, Commentarium in Apocalypsin: o número e a forma geométrica na tradição simbólica das ilustrações do «Beato» de São Mamede de Lorvão

\title{
Commentarium in Apocalypsin: o número e a forma geométrica na tradição simbólica das ilustrações do «Beato» de São Mamede de Lorvão
}

\section{Commentarium in Apocalypsin: number and geometric form in the illustrations of the «Beatus» of Saint Mamas of Lorvão ${ }^{1}$}

\author{
Ana de Oliveira DIAS \\ Department of History, Durham University \\ Centre of History, School of Arts and Humanities of the University of Lisbon \\ a.p.c.dias@durham.ac.uk
}

Recibido: $10 / 03 / 2015$

Aceptado: 24/05/2015

Resumo: O número e a geometria foram durante séculos entendidos como elementos fundamentais da espiritualidade medieva e considerados pelos grandes Padres da Igreja grega e latina como a chave para o alcance da verdadeira compreensão da Criação e da Revelação divina. Tomando o único «Beato» ilustrado em contexto português -cópia da obra literária da Alta Idade Média hispânica Commentarium in Apocalypsin de Beato de Liébana, e replicado no scriptorium do Mosteiro de São Mamede de Lorvão- como objecto central de estudo, procuramos pautar o presente trabalho pela análise do imaginário e simbólica associados ao domínio do número e da forma geométrica expressos no programa iconográfico e iconológico deste manuscrito tardio na tradição dos «Beatos» e, nesta perspectiva, demonstrar o papel crucial que a «ciência numérica» desempenhou, não somente para a concepção e recepção da mensagem espiritual desta obra -com um carácter verdadeiramente conceptual e ascético-como no entendimento e reforço da antiguidade do cânone ilustrativo da cópia que ora analisamos.

Palavras-chaves: Commentarium in Apocalypsin, «Beatos», simbólica, imaginário, número, numerologia, forma geométrica.

Abstract: For centuries number and geometry were seen as the fundamental elements of

${ }^{1} \mathrm{O}$ presente trabalho constitui a versão integral da dissertação de mestrado apresentada à Faculdade de Letras da Universidade de Lisboa em Feveiro de 2012, e defendida em Julho do mesmo ano. Este estudo contou com a orientação dos Professores Pedro Gomes Barbosa e Hermenegildo Fernandes, da mesma faculdade, aos quais reforço o meu agradecimento pelo apoio e pelos valiosos conselhos durante este percurso. O texto que ora apresentamos foi inteiramente redigido no ano de 2011, e apesar de fiel à versão então apresentada, foi alvo de correcções menores. Pedimos, porém, desculpas ao leitor por eventuais lacunas que nos possam ter passado despercebidas mesmo após estes anos, e compreensão aquando da leitura de um texto produzido nos inícios do nosso percurso académico. Gostaríamos ainda de agradecer, uma vez mais, a todos os que fizeram parte desta jornada de três anos (2009-2012) e que tornaram possível a realização deste trabalho: aos meus pais, a Stuart Morle, ao amigo e colega Hugo Miguel Crespo pelos seus preciosos conselhos, Madalena da Costa Cabral de Herédia, André de Oliveira Leitão, Filipa Santos e Thiago Borges; um agradecimento especial também à Professora Maria João Branco, arguente destas provas de mestrado, e ao Arquivo Nacional da Torre do Tombo, em particular ao Dr. Paulo Tremoceiro, pela cedência de imagens para publicação neste artigo. Por último, agradecemos ao Professor Jose Maria Salvador Gonzalez pelo convite para a publicação deste trabalho na presente revista académica. 
Ana de Oliveira DiAs, Commentarium in Apocalypsin: o número e a forma geométrica na tradição simbólica das ilustrações do «Beato» de São Mamede de Lorvão

medieval spirituality, and were considered by early Greek and Latin theologians to be the key to achieving true enlightenment about creation and divine revelation. Taking as our central subject the only illustrated Portuguese copy of the early medieval work Commentarium in Apocalypsin of Beatus of Liébana, from the scriptorium of Saint Mamas of Lorvão, this study provides an analysis of symbolic imagery based on number and geometrical form expressed in the iconographic and iconological programme of this late manuscript from the Hispanic Beatus tradition. In this perspective, we attempt to describe the crucial role played by the «science of number», not only in the conception but also in the reception of this work and of its spiritual message, and how these features reinforce the antiquity of this pictorial model.

Keywords: Commentarium in Apocalypsin, «Beatus», symbology, imagination, number, numerology, geometrical form.

Sumario: 1. Introdução. 2. Commentarium in Apocalyspin e a cópia ilustrada do mosteiro de São Mamede de Lorvão: tradições e contextos de produção. 2.1. Commentarium in Apocalyspin: o autor e a obra. 2.2 O Comentário à luz de uma tradição textual. 2.3 O Comentário à luz de uma tradição pictórica. 2.4. Usos e funções: o entendimento ideológico da obra literária. 2.5. Similitudes e descontinuidades entre os séculos VIII e XII. 3. O «Beato» de São Mamede de Lorvão: o códice e os contextos de produção. 3.1. Mosteiro de São Mamede de Lorvão: apontamentos biográficos. 3.2 . O «Beato» laurbanense: apontamentos codicologicos. 3.3. O scriptorium - panorama de produção literária: relações e influências no século XII. 3.3.1. Circulação de modelos e manuscritos. 4. A simbólica do número e da forma geométrica no «Beato» de Lorvão: relevância aritmológica e mensagem espiritual . 4.1. A «Ciência numérica»: das correntes da Antiguidade à exegese medieval. 4.2. O número e a forma geométrica nas ilustrações do «Beato» de Lorvão. 4.2.1. O número: análise quantitativa. 4.2.2. O número nas ilustrações do «Beato» de Lorvão: análise qualitativa. 5. A forma geométrica: figuras e tendências geometrizantes nos manuscritos hispânicos. 5.1. A forma geométrica nas ilustrações do «Beato» de Lorvão: análise quantitativa. 5.2. A forma geométrica no «Beato» de Lorvão análise qualitativa. 6. Conclusão. 7. Anexo Iconográfico. Fontes e Bibliografia.

\section{Introdução}

Desde cedo, no nosso jovem e modesto percurso académico, foi manifesta a vontade e intenção de enveredarmos por um caminho que partilhasse e aliasse, de forma estreita, a arte — na sua qualidade documental - à História da cultura e das mentalidades, visando a compreensão da função e das motivações por detrás da concepção do objecto artístico, sendo este um veículo de sentidos e significados, e espelho desta dimensão complexa, porém omnipresente: o imaginário, um pilar profundo e estruturante de todas as sociedades históricas.

Neste sentido, procurámos pautar o nosso percurso até à data pelo estudo sistemático do imaginário, dos mirabilia, ${ }^{2}$ e do pensamento simbólico na arte, tendo enveredado por uma cronologia fértil nestas manifestações. Falamos pois da Idade Média e da interessante e complexa sociedade medieval.

Como referido, a obra de arte - paixão primordial que nos motivou e conduziu à formação base na área da História da Arte e Património- constituiu o primeiro pretexto para a exploração e penetração nestes domínios. Movidos,

\footnotetext{
2 Jacques LE GOFF, O Imaginário medieval, Lisboa, Estampa, 1994, p. 49.
} 
Ana de Oliveira DiAs, Commentarium in Apocalypsin: o número e a forma geométrica na tradição simbólica das ilustrações do «Beato» de São Mamede de Lorvão

então, não somente por essa paixão, mas conscientes da pertinência e importância do estudo do imaginário, procurámos levar a cabo uma investigação baseada na análise de códigos imagéticos e da sua função na obra medieval. Como referiu Michel Pastoureau «L'imaginaire fait toujours partie de la réalité, l'imaginaire est une réalité» ${ }^{3}$, evidenciando assim, de modo claro, a necessidade de estudos sérios e sistemáticos neste campo, como único meio para o conhecimento da «natureza profunda do Homem». ${ }^{4}$

Não obstante, pedregosos são os trilhos do historiador neste ofício e fáceis são os juízos incautos, tal como a falta de distanciamento necessária para a adequada interpretação de um modus faciendi tão distante dos esquemas mentais contemporâneos. Como apontámos num estudo anterior, «é, pois, necessário um constante exercício de desprendimento de si e do seu tempo, efectuar como que uma catábase na tentativa de nos aproximarmos da leitura que as diferentes sociedades, ao longo da História, fizeram do seu próprio imaginário» ${ }^{5}$, votados sempre a um rigor, prudência e honestidade científica, como únicos meios conducentes à aproximação dos frágeis vestígios que possuímos. Cremos, portanto, que devem ser reunidos esforços no sentido de integrar, de forma consciente e convicta, a análise das estruturas do imaginário no discurso historiográfico corrente, que por tanto tempo os negligenciou, firmando-se num exercício de interpretação meramente factual, sendo apenas ressalvado por um número reduzido de historiadores contemporâneos, como Jacques Le Goff, George Duby, Michel Pastoureau ou, no caso português, José Mattoso. Inspirados precisamente pela obra deste último historiador, e tomando o seu artigo $O$ imaginário na iluminura medieval ${ }^{6}$ como influxo, debruçámo-nos então sobre este media artístico, apesar de cientes da sua realidade irremediavelmente fragmentária.

Deste modo, o projecto que ora apresentamos visa compreender o manuscrito Commentarium in Apocalypsin produzido no mosteiro do Lorvão - cópia datada de 1189- à luz e no contexto da cultura hispânica letrada do século XII, através da avaliação dos seus códigos simbólicos, expressos através do número e da forma geométrica. Estrutura-se então a presente investigação em dois blocos principais: um primeiro dedicado à tradição e contextos de produção da obra original e da cópia laurbanense, visando compreender e analisar as contingências históricas, mentais e estéticas na base da concepção destes manuscritos, e um

\footnotetext{
${ }^{3}$ Michel PASTOUREAU, Une Histoire Symbolique du Moyen Âge Occidental, Paris, Seuil, 2004, p. 19.

${ }^{4}$ Jacques LE GOFF, p. 17.

5 Ana de Oliveira DIAS, "Os «mischwesen» nas Tentações de Santo Antão de Hieronymus Bosch - as estruturas do imaginário medieval nos alvores da Época Moderna", in Seminário Internacional Tarouca e Cister: O Imaginário e o património de Cister no Douro, Tarouca, Câmara Municipal de Tarouca (no prelo).

${ }^{6}$ José MATTOSO, "O imaginário da iluminura medieval", in A iluminura em Portugal. Identidade e Influências, catálogo de exposição bibliográfica, (comissariado científico e geral de Maria Adelaide MIRANDA), Lisboa, Ministério da Cultura - Biblioteca Nacional, 1999, pp. 25-37.
} 
segundo ponto, no qual nos debruçamos sobre a auscultação do programa numérico e geométrico nas ilustrações do códice de Lorvão, e na procura da interpretação e entendimento desses mesmos códigos numerológicos — da sua génese, natureza e qualidades simbólicas - à luz do modelo espiritual de Beato, tal como o seu impacto e significado na cultura monástica hispânica entre os séculos VIII e XIII. Pretendemos também apurar e compreender a existência de um programa iconológico no «Beato» de São Mamede de Lorvão assente no número e na forma geométrica, assim como entender a sua influência nas preocupações exegéticas e escatológicas desta comunidade, contribuindo deste modo para um entendimento mais amplo das dinâmicas e práticas espirituais dos monges laurbanenses nesta cronologia.

Assim, com base no estudo atento das fontes clássicas, dos textos litúrgicos da tradição hispânica, tal como na análise das restantes cópias remanescentes essencialmente do ramo codicológico em que figura cópia laurbanensepretendemos conceber a nossa investigação, confiando de que esta análise poderá conduzir à formulação de novas e fundamentais questões, assim como a um somatório pertinente de novas interpretações para o estudo da simbólica e do imaginário veiculado neste manuscrito ímpar no panorama dos «Beatos» hispânicos.

\section{Commentarium in Apocalyspin e a cópia ilustrada do mosteiro de são mamede de lorvão: tradições e contextos de produção}

\subsection{Commentarium in Apocalyspin: o autor e a obra}

$\mathrm{Na}$ historiografia actual o termo «Beatos» é-nos familiar por definir um grupo extremamente específico de manuscritos — cuja produção é compreendida entre os séculos VIII e XIII-, considerados pela sua unidade artístico-literária ímpar no panorama da Idade Média ocidental. Estes constituem uma cópia parcial, comentário e ilustração do grande Livro do Apocalipse de São João, obra incontornável e repertório extremamente fértil para um imaginário colectivo medieval. ${ }^{7} \mathrm{O}$ recurso a esta terminologia deve-se à atribuição da concepção do manuscrito-arquétipo ao monge asturiano, conhecido como Beato de Liébana, associado ao mosteiro de San Martin de Turieno (actualmente Santo Toríbio), na região cantábrica de Liébana. Beato foi, então, apontado como autor do primeiro códice, hoje desconhecido, que terá dado origem a toda uma longa tradição textual e pictórica, testemunhada por cerca de três dezenas de cópias que a sua obra mereceu. ${ }^{8}$

\footnotetext{
${ }^{7}$ Jacques LE GOFF, p.58. Obra incontornável para o estudo da simbólica e do imaginário medieval. Jacques Le Goff direcciona-se essencialmente para uma abordagem antropológica da História medieval, constituindo para nós uma importantíssima base e inspiração metodológica desde os inícios dos nossos estudos.

${ }^{8}$ Manuel DÍAZ Y DÍAZ, "Le texte de «Los Beatos»", in Los Beatos, catálogo de exposição bibliográfica (comissariado científico e geral de Peter COCKSHAW), Chapelle de Nassau, Biblioteca Real Alberto I, 1985, pp. 9-17, ref. p. 9. A exposição intitulada «Los Beatos», organizada pela Europália em 1985, numa colaboração com a Bibliothèque Royale Albert I ${ }^{\mathrm{er}}$,
} 
Ana de Oliveira DiAs, Commentarium in Apocalypsin: o número e a forma geométrica na tradição simbólica das ilustrações do «Beato» de São Mamede de Lorvão

Do ponto de vista biográfico, Beato de Liébana permanece aos olhos dos historiadores actuais como uma personagem enigmática. Escassos são os dados que possuímos, posicionando-se todos eles num campo insatisfatoriamente hipotético. Crê-se que o monge asturiano tenha de facto vivido na segunda metade do século VIII ${ }^{9}$, desconhecendo-se, porém, a sua origem concreta. Anne de Egry, na sua monagrafia sobre as ilustrações do manuscrito que nos ocupa, reflecte em torno desta questão, sugerindo uma origem norte africana. ${ }^{10}$ Contudo, John Williams defende raízes hispânicas, justificando, porém, a fixação deste clérigo a norte da Peninsula como estratégia de fuga ao avanço muçulmano. ${ }^{11}$ Desconhecemos, do mesmo modo, a sua real condição eclesiástica. Apontado como presbítero por Álvaro de Córdoba ${ }^{12}$, e como abade por Alcuíno ${ }^{13}$, permanece em campo especulativo o estatuto que o monge de Liébana terá de facto assumido no mosteiro asturiano. ${ }^{14}$ A data de 26 de Novembro de $785-\mathrm{em}$ que temos notícia que Beato terá assistido à tomada de véu de Adosinda, viúva do rei Silos ${ }^{15}$ - constitui o único apontamento concreto de que dispomos. A restante informação verosímil prende-se essencialmente com o conteúdo dos seus tratados e das cartas redigidas em torno da defesa da ortodoxia da Igreja, frente a Elipando, bispo de Toledo. Uma única biografia de Beato terá sido concebida por

reuniu, num único espaço, a totalidade de manuscritos -testemunhos da cultura hispânica dos séculos IX a XIII- comumente apelidados de «Beatos». Esta iniciativa constituiu o primeiro olhar de conjunto, na forma de exposição, dando origem a um importante catálogo e volume de estudos que conta com a colaboração de cinco grandes referências para estas áreas: Luis Vázquez de Parga, Manuel Díaz y Díaz (na sua qualidade de filólogo latino), John Williams (para o estudo da imagética do Comentário), Anscari Mundó (atentando nas questões paleográficas) e Manuel Sánchez Mariana, director da Secção de Manuscritos da Universidade de Madrid.

\footnotetext{
${ }^{9}$ John Williams sugere que se partirmos da premissa que o Comentário ao Apocalipse foi uma obra elaborada por Beato de Liébana em 776, e portanto nos inícios da sua maturidade, podemos então estimar que Beato terá nascido em meados do século VIII, provavelmente durante o reinado de Afonso I (739-757) - John WILLIAMS, "Beatus of Liébana", in John WILLIAMS, The illustrated Beatus. A corpus of the illustrations of the Commentary on the Apocalypse, vol. I, Londres, Harvey Miller Publishers, 1994, pp.13-17, ref. p. 14.

${ }^{10}$ Anne de EGRY, Um estudo de O Apocalipse do Lorvão e a sua relação com as ilustrações medievais do Apocalipse, Lisboa, Fundação Calouste Gulbenkian, 1972, p. 22. Estudo que se apresenta como a primeira grande abordagem sistemática em torno da cópia do Comentário ao Apocalipse do mosteiro de Lorvão. Podemos dividir esta obra em dois pontos essenciais: um primeiro momento, teórico, dedicado a questões históricas e estilísticas (produção, autoria, contexto, filiações), e um segundo momento dedicado à (preciosa) auscultação iconográfica, em que a autora procede à identificação das ilustrações nas suas relações com o texto.

${ }^{11}$ John WILLIAMS, "Beatus of Liébana" [...], p. 14.

${ }^{12}$ Juan GIL (ed.), Corpus Scriptorum Muzarabicorum, vol. I, Madrid, Instituto Antonio Nebrija, 1973, p. 179.

${ }^{13}$ PL 101, cols. 103.

${ }^{14}$ Jonh WILLIAMS, "Beatus of Liébana”[...], p. 14.

${ }^{15}$ Luis VÁZQUEZ DE PARGA, “Beatus de Liébana et «Los Beatos»”, in Los Beatos, [...], pp. 3-8, ref. p. 3.
} 
Juan Tamayo de Salazar, na sua obra Martyrologium Hispanum ${ }^{16}$, na qual procurou estabelecer o percurso do monge asturiano, tendo apontado 19 de Fevereiro de 798 como sua data de óbito. ${ }^{17}$ No entanto, não podemos confirmar a veracidade destas informações, dado o carácter pouco científico pelo qual se caracterizou este autor, famoso por forjar as vitae dos santos latinos. ${ }^{18}$

A primeira relação estabelecida, em termos de autoria, entre Beato e o Comentário terá sido apresentada no século XVI por Ambrósio de Morales ${ }^{19}$, bibliógrafo de Felipe II, baseando-se na análise da dedicatória inclusa no Comentário, direccionada a Eterius, bispo de Osma, o qual terá sido o partidário de Beato aquando da famosa querela adopcionista contra o supracitado bispo Toledo. ${ }^{20}$ Apesar de nenhum dos códices conhecidos apresentar qualquer referência quanto à autoria original, Morales reconheceu-o, por este motivo, como o possível autor da obra literária. ${ }^{21}$ John Williams corroborou então esta atribuição ao estabelecer paralelismos estilísticos entre o texto do Comentário e o de Adversus Elipandum, tratado posteriormente redigido por Beato contra a heterodoxia de Elipando. ${ }^{22}$ Contudo, partilhamos da observação de Manuel Díaz y Díaz que sublinha que, lato sensu, referimo-nos a este grupo de manuscritos como «Beatos», mas que ao definir uma autoria devemos sempre rigorosamente sublinhar: «atribuível a Beato de Liébana» ${ }^{23}$, uma vez que todos os manuscritos sobreviventes são objectivamente anónimos.

Enigmático permanece também o fenómeno de aparente desenvolvimento cultural nos remotos vales de Liébana. Apesar do espartilhamento do «enclave» asturiano - reduto da tradição hispano-visigótica- face à ofensiva muçulmana, crê-se que Beato terá tido acesso a uma importante, e relativamente vasta, biblioteca, beneficiando da influência dos grandes centros cosmopolitas situados a sul. ${ }^{24}$ Sugere-se que muitas destas obras terão sido trazidas por clérigos de

\footnotetext{
${ }^{16}$ PL 46, cols. 890-894.

${ }^{17}$ Luis VÁZQUEZ DE PARGA, p. 6.

${ }^{18}$ IDEM, ibidem, p. 6.

${ }^{19}$ Sobre o assunto veja-se Enrique FLÓREZ (ed.), Viage de Ambrosio de Morales por orden del rey D. Felipe II a los reinos de León y Galicia y principado de Asturias para reconocer las reliquias de santos, sepulcros reales y libros manuscritos de las catedrales y monasterios, Madrid, Antonio Martín, 1765.

${ }^{20}$ Sobre este assunto veja-se John WILLIAMS, "Beatus of Liébana" [...], pp. 13 e 14.

${ }^{21}$ Jorge da Silva ROCHA, L'Image dans le Beatus de Lorvão: Figuration, composition et visualité dans les enluminures du commentaire à l'Apocalypse attribué au scriptorium du monastère de São Mamede de Lorvão - 1189, vol. I (tese de doutoramento apresentada à Université Libre de Bruxelles, Faculté de Philosophie et Lettres), Bruxelles, 2007/2008, p. 36 (texto policopiado).

${ }^{22}$ John WILLIAMS, "Beatus of Liébana" [...], p. 13.

${ }^{23}$ Luis VÁZQUEZ DE PARGA, pp. 6-7 (sublinhado nosso).

${ }^{24}$ John WILLIAMS, "Beatus of Liébana” [...], p. 15.
} 
Ana de Oliveira DiAs, Commentarium in Apocalypsin: o número e a forma geométrica na tradição simbólica das ilustrações do «Beato» de São Mamede de Lorvão

Toledo ou Sevilha ${ }^{25}$, que rumaram a norte após a ocupação muçulmana, procurando guarida nestes vales eremíticos, e promovendo assim a circulação de códices e a transmissão de conhecimentos nesta região, então essencialmente rural. Assim, aquando da sua visita à região de Oviedo, Morales testemunhou que esta detinha um número consideravelmente superior de livros antigos por comparação com os restantes reinos de Espanha ${ }^{26}$, constituindo assim prova e exemplo da dimensão cultural do reino das Astúrias, no período altomedieval. Este fenómeno terá certamente contribuído para o desenvolvimento de diversos scriptoria monásticos, tornando-se então esta região num verdadeiro paradigma de resistência cultural e identitária no contexto de uma Peninsula sob o domínio muçulmano.

\subsection{O Comentário à luz de uma tradição textual}

Desde os inícios do século VIII que temos notícia de uma ansiosa espera do fim do tempos. De acordo com São Jerónimo ou Beda, o Venerável, este século era encarado como a segunda Parusia, indo ao encontro da teoria da predestinação da Sexta Idade, em que o primeiro ciclo da vida terrena culminaria ao fim de seis mil anos. ${ }^{27}$ Reflexo preciso desta tensão vivida foi a elaboração de um texto dedicado ao grande Livro do Apocalipse e a emergência de uma literatura-tipo que mergulhava profundamente nos temas milenaristas e nos «terrores» ${ }^{28}$ reinantes em meados do século oitavo. ${ }^{29}$ Temos também notícia que o quarto Concílio de Toledo, em 633, regulamentou como leitura obrigatória em Cânone XVII - o Apocalipse, desde a Páscoa até ao Pentecostes (tal como nos Sábados santos) $)^{30}$, recomendações essas que figuram como glosas em

\footnotetext{
${ }^{25}$ IDEM, ibidem, p. 15.

${ }^{26}$ IDEM, ibidem, p. 16.
}

${ }^{27}$ Sobre este assunto veja-se Juan GIL, "Los terrores del año 800”, in Actas del Simposio para el estudio de los códices del "Comentario al Apocalipsis" de Beato de Liébana, vol. I, Madrid, Joyas Bibliográficas, 1978, pp. 215-247, ref. p. 217.

${ }^{28}$ IDEM, ibidem, p. 215.

${ }^{29}$ Temos notícias que nas crónicas do século VIII, a passagem dos anos era cuidadosamente contabilizada para a estimativa da aproximação do milénio. Muitos autores, como Beato de Liébana, encararam a aritmética e o número como elementos profundamente simbólicos e determinantes nestas contagens, facto verificável através de muitas tábuas e exercícios de conjugações numéricas que observamos em diversos manuscritos deste período. Salientando, como exemplo, as tábuas com o número do Anticristo presente em algumas das cópias do Comentário do Apocalipse. Juan GIL, "Los terrores" [...], pp. 219 e 233.

${ }^{30}$ Apesar da grande importância e expressão que a temática apocalíptica assumiu nas diversas áreas da cultura medieval (particularmente nos domínios artísticos e literários), no âmbito litúrgico não se verificou o mesmo impacto. O Livro do Apocalipse raramente era utilizado nas celebrações eucarísticas ou mesmo no exercício do ofício divino, sendo-lhe atribuído um uso bastante específico, como por exemplo: nos ritos de dedicação de novas igrejas (numa comparação entre o templo terreno e o celeste, descrito na escritura), no dia de Todos-os-Santos, oração das Matinas e por vezes em salmos das Vésperas. Era, essencialmente, evocado a 28 de Dezembro aquando das celebrações do Massacre dos Inocentes. Sobre este assunto veja-se C. Clifford, FLANIGAN, "The Apocalypse and the medieval liturgy", in The Apocalypse in the 
Ana de Oliveira DiAs, Commentarium in Apocalypsin: o número e a forma geométrica na tradição simbólica das ilustrações do «Beato» de São Mamede de Lorvão

algumas das cópias destes manuscritos ${ }^{31}$, demonstrando como a doutrina efectivamente determinou as práticas quotidianas da comunidade.

No entanto, a leitura e comentário ao Apocalipse não constituiu apanágio hispânico. ${ }^{32}$ Temos notícia que o interesse por estes textos é considerável a partir do século II, e objecto de reflexões exegéticas primordialmente no Norte de África. Autores como Tertuliano, Ticónio ou Cipriano são exemplos de exegetas que se dedicaram à temática apocalíptica, influenciando profundamente na construção da obra de Beato. De acordo com Manuel Díaz y Díaz, Ticónio donatista africano do século IV - terá sido a maior referência do monge de Liébana. Também este havia redigido um Comentário da mesma natureza ${ }^{33}$, que provavelmente terá chegado até à Península dados os estreitos laços com o Norte de África desde a invasão muçulmana. ${ }^{34} \mathrm{~A}$ inspiração em autores como Isidoro de Sevilha (Etymologiae), Santo Agostinho (De Civitate Dei) ou Apríngio, bispo de Beja ${ }^{35}$ fizeram-se concomitantemente sentir, constituindo estes exemplos de comentadores e tradições exegéticas determinantes para a concepção do Comentário de Beato, que os nomeia e destaca no prólogo da sua obra.

Deste modo, do ponto de vista da estrutura interna, o texto de Beato organizase em cerca de sete pontos basilares: prólogo (em que introduz a obra, a

Middle Ages (dir. de Richard K. EMMERSON e Bernard MCGINN), Ithaca, Cornell University Press, 1992, pp. 333-351, ref. pp. 333-334.

${ }^{31}$ A cópia portuguesa do mosteiro de Lorvão demonstra que foram introduzidas notas nas margens do manuscrito para "ilustrar" os propósitos de utilização destas obras rituais. No caso do Comentário de Lorvão verificamos que a caligrafia destas glosas não é contemporânea do códice, indício do seu uso continuado nos ofícios litúrgicos a posteriori, Anne de EGRY, p. 30.

${ }^{32}$ Sobre os diferentes autores do Comentários ao Apocalipse veja-se E. Ann MATTER, "The Apocalypse in early medieval exegesis", in The Apocalypse in the Middle Ages [...], pp. 38-50, ref. p. 42.

${ }^{33}$ Temos notícia que Ticónio terá redigido o seu Comentário ao Apocalipse na decorrência da guerra e perseguição dentro da Igreja africana, entre as facções ortodoxa e donatista (da qual se assumia partidário). Para o exegeta, esta obra ganhava força e sentido num contexto de heresias e perseguições religiosas - John WILLIAMS, "Purpose and imagery in the Apocalypse Commentary of Beatus of Liébana", in The Apocalypse in the Middle Ages [...], pp. 217-233, ref. p. 220.

${ }^{34}$ Salientamos o caso do monge Donato que trouxe consigo do Norte de África uma vasta biblioteca pelo ano de 570. A fuga ao avanço vândalo nesta região levou-o a fixar-se na cidade de Valência, no levante da Península Ibérica - Aires Augusto do NASCIMENTO, "A iluminura hispânica primitiva fragmentos de um universo cultural", in A iluminura em Portugal. Identidade e Influências [...], pp.111-125, ref. p. 115. A clara influência norte-africana na obra de Beato conduziu John Williams a revogar as teorias anteriores, sugerindo uma filiação do estilo textual e artístico do Comentário com a produção norte africana, chegada a Espanha no período visigótico, John WILLIAMS, "The Illustrated Commentary" [...], pp. 31-101, ref. pp. 34-36.

${ }^{35}$ Apríngio de Beja, autor que no século VI elaborou uma versão do Comentário ao Apocalipse não ilustrada, inspirado pelo modelo da Igreja de Cartago. Jacques Fontaine refere que este autor não só conheceria o Comentário do donatista africano Ticónio como igualmente possuiria uma cópia deste na sua biblioteca - Jacques FONTAINE, Isidore de Séville. Genèse et originalité de la culture hispanique au temps des Wisigoths, Turnhout, Brepols, 2000, p. 58. 
Ana de Oliveira DiAs, Commentarium in Apocalypsin: o número e a forma geométrica na tradição simbólica das ilustrações do «Beato» de São Mamede de Lorvão

metodologia, fontes e autores utilizados, evocando-se as doutrinas de Santo Isidoro, Santo Agostinho, Gregório Magno, São Jerónimo e Apríngio) ${ }^{36}$, interpretatio (como que explicação condensada do Apocalipse repartida por doze livros, seguidas de passagens exegéticas interpretadas num sentido alegórico e anagógico), Comentário ao Apocalipse (comentário propriamente dito, por Beato de Liébana), Livro de Daniel (comentado por São Jerónimo), De adfinitatibus et gradibus (capítulo dedicado aos parentescos, inspirado nas Etymologiae de Santo Isidoro), Explicit do códice (explicação do códice, de influência isidoriana), e as Geneologias bíblicas. ${ }^{37}$ Assim, nos doze livros copiados e interpretados por Beato contemplamos a síntese dos dois grandes temas da literatura apocalíptica: a Igreja - substância principal (mensagem para as sete Igrejas da Ásia, a destruição da pérfida Babilónia e o início do eterno reino de Deus), e o Anticristo, a vinda deste agente para corromper a humanidade incauta, a perigosa palavra do falso profeta, retratadas nesta obra numa relação de eterna Psicomaquia, que visa denunciar os sinais e preparar a aguardada revelação do fim dos tempos.

Apesar das cerca de trinta cópias remanescentes não apresentarem todas a mesma estrutura textual (fruto dos diferentes protótipos ou de acidentes de transmissão textual) ${ }^{38}$, a constituição do Comentário revela o mérito de Beato no conhecimento, reveneração e perpetuação dos textos patrísticos, na sua ordenação e interpretação pessoal. ${ }^{39}$

Por conseguinte, o estudo dos «Beatos» constituiu um campo fértil de investigação, sendo diversos os autores que se dedicaram à cuidadosa e exaustiva auscultação dos seus conteúdos literários e da forma como as cerca de trinta cópias remanescentes se relacionam entre si: as suas semelhanças mas, principalmente, as suas intrigantes divergências formais. ${ }^{40}$ Díaz y Díaz apontou então como principais problemáticas para o estudo desta obra, a identificação dos textos (que acompanham o texto original), tal como a sua ordem lógica de

${ }^{36}$ É neste momento estrutural do Comentário que observamos, na grande maioria das cópias, a dedicatória da obra a Etério, bispo de Osma, Manuel DÍAZ Y DÍAZ, "Le texte de «Los Beatos»" [...], p. 10.

${ }^{37}$ De todos os textos referidos somente os pontos três e quatro apresentam ilustrações. Contudo as genealogias bíblicas, quando integradas na cópia, podem igualmente apresentar imagens à semelhança dos manuscritos bíblicos - Manuel DÍAZ Y DÍAZ, "Le texte de «Los Beatos»" [...], p. 9. Este autor assume-se como um dos autores de referência para o estudo da problemática textual e codicológica dos «Beatos». Os seus trabalhos abarcam as matérias relacionadas com a filologia latina, codicologia, paleografia e cultura livresca essencialmente da Alta Idade Média espanhola, constituindo, para nós, preciosos auxiliares para a compreensão das temáticas que ora exploramos. Devemos ainda sublinhar que nem todos os «Beatos» apresentam a mesma estrutura interna, sendo o exemplar de Lorvão um dos que se encontra truncado.

${ }^{38}$ Anne de EGRY, p. 23.

${ }^{39}$ IDEM, ibidem, p. 23.

${ }^{40}$ Sobre teoria da crítica textual e a formação de um stemma codicum veja-se Leighton REYNOLDS, Nigel WILSON, "Critica del texto", in Copisti e Filologi - la tradizione dei classici dall'antichita' ai tempi moderni, Padova, Editrice Antenore, 1987, pp. 219-244. 
inserção no todo, as suas origens, as fontes e a sua «mise-en-oeuvre». ${ }^{41}$ Dadas as evidentes heterogeneidades dentro do grupo de manuscritos, Wilhelm Neuss estabeleceu, nos anos trinta do século XX, a sua divisão em três grupos ou famílias $^{42}-\mathrm{I}$, IIa, IIb - de acordo com a tipologia destes «Beatos». Neuss terá então elaborado um stemma codicum atentando, em particular, na tradição textual, assumindo o Beato de Saint-Server (cópia da Bibliothèque nationale de Paris $[\mathbf{S}]$ ) como o exemplar mais próximo de um único arquétipo original.

Henry Sanders, na mesma época, defendeu que os comentários apresentam as suas variações com base em diferentes redacções elaboradas ainda no tempo de Beato ditando, desta forma, as diferenças observáveis nas três famílias determinadas por Neuss. Estimou Sanders que uma primeira edição terá sido elaborada em 776, seguindo-se uma segunda e terceira em 784 e $786^{43}$ e, assim, estabeleceu uma metodologia de estudo dos «Beatos» assente sobre as suas características textuais, na perspectiva do entendimento da sua génese e estilo.

Contudo, em 1976, Peter Klein ${ }^{44}$ propôs um novo olhar e metodologia e, num cruzamento de ideias entre Neuss e Sanders, estabeleceu um parâmetro de análise distinto, que advoga ser necessária a separação entre uma análise textual e pictórica para uma compreensão verdadeiramente ampla e rigorosa destes manuscritos emblemáticos.

\subsection{O Comentário à luz de uma tradição pictórica}

O Comentário ao Apocalipse terá sido, sem margem para dúvida, uma obra literária bastante divulgada na região peninsular, não somente pela importância do seu texto, como também pela sumptuosidade das suas imagens. Apesar de desconhecermos se o primeiro exemplar terá sido efectivamente ilustrado ${ }^{45}$, são

\footnotetext{
${ }^{41}$ Manuel DÍAZ Y DÍAZ, "Le texte de «Los Beatos»" [...], p. 9.

${ }^{42}$ Jorge da Silva ROCHA, pp. 28- 29.

${ }^{43}$ A terceira edição encontra-se representada tipologicamente pelo «Beato» de Morgan (M), elaborado pelo copista moçárabe Magius (ou Maius) de San Miguel de Escalada. Sobre este assunto veja-se Peter KLEIN, "La tradición pictórica de los Beatos" [...], pp. 83-106, ref. p. 86.

${ }^{44}$ Peter Klein dedicou uma parte substancial dos seus estudos à tradição pictórica dos «Beatos», dando início a uma nova linha de abordagem, com base na evolução histórica e estilística das ilustrações. É igualmente autor dos mais recentes estudos sobre a origem e filiação das cópias do Comentário ao Apocalipse, revogando sugestões anteriores dos especialistas Wilhelm Neuss e John Williams quanto à antiguidade de alguns manuscritos. Klein dedicou também a sua atenção à cópia laurbanense, num estudo individual, produzido aquando da edição do fac-simile desta cópia no ano de 2004 - Peter KLEIN, Beato de Liébana: la ilustración de los manuscritos de Beato y el Apocalipsis de Lorvão, trad. Beatriz Mariño, Valencia, Patrimonio Ediciones, 2004.
}

${ }^{45}$ Jorge da Silva ROCHA, p. 29. 
Ana de Oliveira DiAs, Commentarium in Apocalypsin: o número e a forma geométrica na tradição simbólica das ilustrações do «Beato» de São Mamede de Lorvão

precisamente estas «rubricas pictóricas» ${ }^{46}$ que tornaram estes manuscritos incontestáveis obras no panorama da arte medieval ocidental. ${ }^{47}$

Para Peter Klein, o estudo rigoroso da tradição dos «Beatos» exige o estabelecimento de uma divisão entre a tradição textual e a pictórica que, na sua óptica, seguem caminhos distintos. ${ }^{48}$ Para uma compreensão global destas cópias, tornam-se então necessários estudos complementares, assentes sobre uma análise estatística $^{49}$ e histórica ${ }^{50}$ dos elementos ilustrativos. ${ }^{51}$ Desta forma, o autor estabeleceu um novo paradigma, criando um stemma baseado na tradição pictórica, e num sistema de parentesco entre as iluminuras. Sugere assim Klein que a família I corresponde a uma versão ilustrativa mais antiga, concluindo que a primeira redacção pictural data do ano de 784, enquadrando-se estes códices numa segunda edição textual. ${ }^{52}$ Por outro lado, verificou que os manuscritos considerados seguidores da edição textual de 776 apresentam uma tradição pictórica mais tardia, indício de que, muito provavelmente, a primeira redacção de 776 terá constituído um exemplar sem ilustrações. ${ }^{53}$ Assim, de acordo com este autor, a origem destas miniaturas constitui uma das questões de maior complexidade de análise para os investigadores. Wilhelm Neuss defendeu que o arquétipo destas ilustrações corresponderia a um modelo clássico, ideia que foi refutada nos estudos mais recentes por John Williams e Peter Klein, que advogam uma influência visigótica ou norte-africana. ${ }^{54}$ Contudo, esta filiação é sempre delicada e imprecisa, uma vez que a inexistência de exemplares artísticos asturianos anteriores, e mesmo coetâneos, impossibilita a elaboração de sólidos estudos comparatistas.

${ }^{46}$ Expressão utilizada por John Williams para evidenciar o carácter recapitulativo das imagens das storiae, como mediadoras ou evocativas da memória - John WILLIAMS, "The uses of the Commentary and its Imagery" [...], pp. 103- 141, ref. pp. 120 e 129.

${ }^{47}$ John WILLIAMS, “The Illustrated Commentary" [...], p. 31.

${ }^{48}$ Peter KLEIN, "La tradicion pictórica [...], p. 88.

49 «Método estatístico ou de correlação»: visa compreender o grau de parentesco entre os «Beatos» das diferentes famílias de forma analítica, quantitativa e objectiva - Peter KLEIN, "La tradicion pictórica [...], p. 90.

${ }^{50}$ «Método histórico»: visa a compreensão das continuidades e descontinuidades entre tradições pictóricas dos «Beatos» - Peter KLEIN, "La tradicion pictórica [...], p. 90.

${ }^{51}$ IDEM, ibidem, p. 88.

${ }^{52}$ Peter KLEIN, "La tradicion pictórica [...], p. 95.

${ }^{53}$ IDEM, ibidem, p. 95.

${ }^{54}$ Verifica-se que o texto das storiae do Comentário de «Beato» é uma versão norte-africana pré-Vulgata, empregada por Ticónio. Esta questão aponta-nos pistas para a provável cópia das miniaturas da mesma fonte. Também o paralelismo com a mosaística da Antiguidade tardia norte-africana, permite-nos analisar a influência desta no estilo artístico do monge asturiano John WILLIAMS, "The Illustrated Commentary" [...], pp. 34 e 36. Ainda em torno desta questão, Peter Klein fortalece esta tese, rejeitando a filiação italiana ou da Europa central, dada a evidente discrepância entre os ciclos do Apocalipse aí conhecidos e o estilo das cópias dos «Beatos» - Peter KLEIN, "La tradicion pictórica [...], p. 104. 
Ana de Oliveira DiAs, Commentarium in Apocalypsin: o número e a forma geométrica na tradição simbólica das ilustrações do «Beato» de São Mamede de Lorvão

Efectivamente, as cerca de cento e oito imagens canónicas conhecidas dos «Beatos» continuam a constituir uma nascente de questões. Acreditamos, porém, que a cópia mais antiga e mais próxima do primeiro estágio da tradição de Beato - contrariando a teoria de Neuss - terá sido o fragmento de Silos, revelando através do seu carácter simples e esquemático ${ }^{55}$ a sua proximidade e filiação aos manuscritos da família I do stemma codicum de Klein. As famílias IIa e IIb, por seu lado, evidenciam uma maior complexificação no estilo das ilustrações, demonstrando uma maior (e mais clara) variedade de influências na sua concepção imagética. A partir do século IX começamos paulatinamente a assistir à introdução de flagrantes elementos decorativos da dita "escola moçárabe", ${ }^{56}$ importante difusora de influências estéticas e literárias na Península Ibérica, assim como grande cultora do Comentário ao Apocalipse. ${ }^{57}$ Não obstante, também a influência carolíngia se fez sentir estilisticamente em algumas das cópias mais tardias (em particular da família IIb), evidência da relação vivaz entre estes mosteiros e as casas religiosas hispânicas. ${ }^{58}$

Não devemos ainda ignorar a influência muçulmana em alguns exemplares destes Comentários, contudo, vislumbramos uma influência muito mais estilística (como elementos arquitectónicos ou da cultura material) do que propriamente empréstimos determinantes de carácter iconográfico, dada a própria natureza anicónica da arte islâmica. ${ }^{59}$ Permanece, portanto, em aberto, a discussão quanto à filiação do arquétipo deste corpus textual e iconográfico, na certeza, porém, que a tradição pictórica cumpre ser estudada individualmente, dados os particularismos e constante evolução que os paradigmas ilustrativos demonstraram sofrer ao longo dos tempos.

\subsection{Usos e funções: o entendimento ideológico da obra literária}

O Livro do Apocalipse - uma das primeiras grandes obras da literatura cristã, representando as visões do apóstolo João aquando do seu exílio em Patmos ${ }^{60}-$

${ }^{55}$ John WILLIAMS, "The Illustrated Commentary" [...], p. 39. O fragmento do mosteiro beneditino de São Domingos de Silos constitui o exemplar mais antigo que conhecemos da tradição dos «Beatos», remontando aos finais do século IX - veja-se Anexo iconográfico, Fig. 36.

${ }^{56}$ IDEM, ibidem, p. 62. Sobre o estilo e influência da arte moçárabe na pintura veja-se Jacques FONTAINE, L'art préroman hispanique 1, 1973-1977, Zodiaque, 1973-1977; Mireille MENTRÉ, La peinture mozarabe, Paris, Presses Universitaires de France, Sorbonne, 1984.

57 Sobre cultura e liturgia moçárabe veja-se Jacques FONTAINE, El mozárabe, Madrid, Encuentro, 1984; Jordi PINELL, Liturgia hispánica, Barcelona, Biblioteca Litúrgica, 1998.

${ }^{58}$ John WILLIAMS, “The Illustrated Commentary" [...], p. 94.

59 Sobre a influência islâmica nos «Beatos» veja-se John WILLIAMS, "The Illustrated Commentary" [...], p. 95.

${ }^{60}$ Diversos especialistas relacionam a redacção do Livro do Apocalipse com a época de intensa perseguição dos mártires cristãos no Império Romano, afirmando-se como um texto de apelo à persistência, esperança no fim dos tempos e no advento do eterno júbilo para os fiéis a Deus Bernard MCGINN, "Introduction: John's Apocalypse and the Apocalyptic mentality", in The Apocalypse in the Middle Ages [...], pp. 3-19, ref. p. 13. 
Ana de Oliveira DiAs, Commentarium in Apocalypsin: o número e a forma geométrica na tradição simbólica das ilustrações do «Beato» de São Mamede de Lorvão

constituiu um campo de extrema popularidade, fascínio e relevância no seio da cultura e mentalidade medieva. A sua linguagem profundamente simbólica e codificada $^{61}$ sempre funcionou como pólo atractivo, sugerindo para o homem mais do que um poderoso desígnio, uma experiência espiritual e sensorial total, dotada de imagem, cor, e som, afirmando-se como um desafio hermenêutico constante que, consequentemente, contribuiu para origem e criação de uma imagética e imaginário ímpares. ${ }^{62}$ As descrições do evangelista -agente visionário entre o plano terreno e o divino, homem mediador de Deus - abriram as mentes e despertaram os sentidos para os sinais que anunciariam o futuro eminente: o caminho para o fim dos tempos, para o qual os espíritos teriam que estar conscientemente atentos.

Contudo, no entendimento de autores como Yves Christe ${ }^{63}$, o Livro do Apocalipse, até aos inícios do século XII, não terá sido interpretado num sentido escatológico. Segundo este autor, a sua leitura prendia-se em princípio com uma tradição eclesiológica, uma parábola em torno da Igreja ${ }^{64}$, da sua integridade e da eterna batalha travada contra o mal, nas suas múltiplas formas. ${ }^{65}$ Porém, esta

${ }^{61}$ Sobre o sentido da mensagem apocalíptica veja-se Henri STIERLIN, Le livre de Feu. L'apocalypse et l'art mozarabe, Paris, Bibliothèque des Arts, 1978, p. 68.

${ }^{62}$ Como afloramos anteriormente, o imaginário medieval sofreu grande influência grande Livro do Apocalipse (o que Le Goff nomeou como «maravilhoso bíblico»- Jacques LE GOFF, $O$ imaginário [...], p. 58), não somente a nível visual como literário. Também nas canções de gesta é visível o seu valimento, como por exemplo na Quest del Saint Graal em que Bors, Galaad e Perceval recebem uma visão que assegura o sucesso das suas metas, sob a forma da aparição dos quatro evangelistas e do som da voz divina e do trovão - Richard K. EMMERSON, "The Apocalypse in Medieval Culture", in The Apocalypse in the Middle Ages [...], p. 325.

${ }^{63}$ Yves CHRISTE, "The Apocalypse in the monumental art of the eleventh through thirteen centuries" [...], pp. 234-258, ref. pp. 237-238. Permanece discutível qual o verdadeiro entendimento e função do Apocalipse desde a sua génese enquanto texto literário, na medida que autores como Peter Klein advogam uma dualidade de sentidos: um paralelo religioso e social da Igreja e da Cristandade, assim como a preparação para a chegada do fim dos tempos Peter KLEIN, "Introducion: The Apocalypse in Medieval Art", in The Apocalypse in the Middle Ages [...] pp. 83-106, ref. pp. 161 e 162.

${ }^{64} \mathrm{O}$ Livro do Apocalipse pode ser entendido como uma a grande Psicomaquia da Cristandade e nesse sentido sugere ao leitor um conjunto de dicotomias que espelham a acção da Igreja no seu eterno combate. Ao auscultarmos esta obra apreendemos, claramente, as relações entre os agentes da visão apocalíptica: Jerusalém vs. Babilónia, Mulher virtuosa vs. prostituta da Babilónia, duas testemunhas vs. besta do abismo, numa relação constante de pares que se opõem.

${ }^{65}$ Do ponto de vista da nossa interpretação, esta questão revela-se determinante para a compreensão dos intuitos de Beato de Liébana ao conceber o seu Comentário, dada a dualidade de conjunturas passíveis de entender no período da sua produção. Relembramos que, anteriormente no nosso estudo, referimos que desde os primórdios do século VIII (período correspondente à produção do texto de Beato), se vivia um clima de tensão assente sobre as ideia da chegada da Sexta Idade. Esta questão coloca-nos perante a interrogação sobre quais as motivações do monge de Liébana ao conceber a sua obra e a qual tradição podemos associar essas mesmas intenções: se uma tradição escatológica ou eclesiológica, ou mesmo se a uma natural fusão entre ambas. 
Ana de Oliveira DiAs, Commentarium in Apocalypsin: o número e a forma geométrica na tradição simbólica das ilustrações do «Beato» de São Mamede de Lorvão

questão permanece em debate, sendo apresentadas diferentes posições que fortalecem a ideia de que um sentido mais profundo fora atribuído a esta obra, mesmo em períodos recuados.

Sabemos que o Apocalipse — «flor da teologia» medieval ${ }^{66}$ - exerceu uma constante atracção sobre teólogos, exegetas, poetas e escritores, ou mesmo sobre o domínio da arte, que desde o século IV, e na sequência de um Cristianismo triunfante, apresentou os seus primeiros modelos iconográficos ${ }^{67}$, em particular na mosaística, na escultura monumental e em diferentes ciclos de livros iluminados. Um dos mais reconhecidos foi precisamente o dos «Beatos» hispânicos, que se transformou nesse corpus sui generis, dada a homogeneidade temática, singularidade ilustrativa e dada a sua extraordinária continuidade de reprodução por mais de cinco séculos.

\subsection{Similitudes e descontinuidades entre os séculos VIII e XII}

Como apontamos anteriormente, permanecem discutíveis as motivações que conduziram Beato à produção do seu Comentário ao Apocalipse, pois nem mesmo o texto de sua autoria veicula qualquer tipo de pista elucidativa em torno desta questão. Considerando, uma vez mais, o carácter compilativo da obra do monge de Liébana (que segue a exegese de autores anteriores) ${ }^{68}$, qualquer tentativa de interpretação e reconhecimento da função desta obra e das suas ilustrações terá que depender maioritariamente de um diligente esforço de entendimento histórico, mais do que de uma interpretação textual, como afirma John Williams. ${ }^{69}$ Foi em tempos apontada como possível motivação a citada querela adopcionista, afirmando que o Comentário de Beato constituiria um texto combativo face à heresia toledana ${ }^{70}$ (como que à semelhança de Ticónio, ou mesmo do apóstolo João, que usaram a palavra para revelar as tensões e

${ }^{66}$ Expressão utilizada por Richard K. Emmerson, no seu estudo em torno do papel do Apocalipse na cultura medieval - Richard K EMMERSON, "The Apocalypse in Medieval Culture", in The Apocalypse in the Middle Ages [...], pp. 293-332, ref. p. 293. Este autor apresenta-se como editor desta incontornável compilação de estudos, que constituiu um precioso suporte para a concepção do nosso trabalho, dada a visível e reconhecida a escassez de estudos especializados subordinados a esta temática em específico.

${ }^{67}$ Peter KLEIN, "Introduction: The Apocalypse in Medieval Art", in The Apocalypse in the Middle Ages [...], p. 161.

${ }^{68}$ Ao procurarmos entender um discurso simbólico de Beato devemos ter sempre em atenção que, no caso do Comentário ao Apocalipse, a grande maioria da informação veiculada pertence a autores anteriores e deste modo, devemos entender que esta linguagem procede dos antecessores de Beato e não tanto do próprio autor. Contudo, como afirma Leslie Freeman, esta selecção permite, porém, entender quais os interesses, preocupações e mesmo o mundo simbólico que «povoava» a cultura eclesiástica contemporânea ao monge de Liébana - Leslie G. FREEMAN, "Elementos simbólicos en la obra de Beato", in ECHEGARAY, Juan G., CAMPO, Alberto del, FREEMAN, Leslie, Beato de Liébana: Obras completas y complementarias, Madrid, Biblioteca de Autores Cristianos, 2004, pp. 33-56, ref. p. 34.

69 John WILLIAMS, " Purpose and imagery in the Apocalypse Commentary of Beatus of Liébana" in The Apocalypse in the Middle Ages [...], pp. 217-233, ref. pp. 219-220.

${ }^{70}$ IDEM, ibidem, p. 221. 
Ana de Oliveira DiAs, Commentarium in Apocalypsin: o número e a forma geométrica na tradição simbólica das ilustrações do «Beato» de São Mamede de Lorvão

perseguições vividas no seio da Igreja). Esta sugestão cai, porém, por terra, ao constatarmos que, aquando da possível redacção da obra, Elipando ainda não havia sido nomeado bispo de Toledo. ${ }^{71}$

Permanece igualmente como incógnita se a ofensiva pagã na Península Ibérica terá fomentado a ebulição do espírito apocalíptico, constituindo a obra de Beato um instrumento combativo - e metafórico- dessa mesma realidade. No entanto, nem o texto, nem mesmo a iconografia revelam qualquer compromisso directo anti-islâmico, como é passível de observar em textos posteriores. ${ }^{72}$

$\mathrm{O}$ propósito das ilustrações permanece assim em terreno incerto, visto não possuirmos qualquer referência efectiva quanto à sua função. Considerando a possível inexistência de iluminuras na primeira versão do Comentário, a consequente opção de ilustração poderá advir da procura de um entendimento mais imediato do conteúdo textual num exercício afim com o da lectio divina ${ }^{73}$, em que a memorização e a meditação nas storiae poderia ser conseguida através da observação da imagem. Esta ideia vai ao encontro da doutrina Gregoriana, segundo a qual a percepção visual constituiria um determinante instrumento didáctico para refrear o engano.

Contemplamos igualmente a imagem - essa nova experiência triunfante entre a Cristandade ocidental - como veículo mimético, mas devocional, da palavra e dos desígnios divinos, revelando-se estas iluminuras como uma construção de carácter ritual dedicadas à sublimação das verdades e dos valores espirituais, factor este que evidencia o poder efectivo da recriação imagética dos conteúdos textuais. Um exemplo flagrante da força e função destas figurações pode ser compreendido através da observação de alguns fólios do Comentário de Lorvão - como os casos dos fls. $186 \mathrm{v}$ e 201 - em que as faces dos agentes maléficos representados se encontram premeditadamente rasuradas, num gesto apotropaico, denotando não somente a vivência do manuscrito, mas também a importância

${ }^{71} \mathrm{O}$ texto do Comentário ao Apocalipse de Beato de Liébana não apresenta qualquer referência directa ao caso da controvérsia adopcionista para que possamos estipulá-la como «leitmotif» da sua redacção; questão que, no nosso entendimento, Beato não necessitaria de apresentar veladamente, visto que em textos como Adversus Elipandum não se coibir a críticas directas ao bispo toledano.

${ }^{72}$ Crê-se igualmente que no tempo de Beato (e na região asturiana e cantábrica) ainda não existisse um entendimento claro e pleno do Islão enquanto ameaça religiosa. Uma das primeiras obras deste carácter que temos notícia terá sido redigida por Paulo Álvaro em 854, autor que poderá ter conhecido e se inspirado no texto de Beato de Liébana para a sua redacção. Por conseguinte, consideramos que o desenvolvimento de um espírito apocalíptico face à irrupção muçulmana na Península, fará mais sentido a partir do século IX, aquando da intensificação da ocupação territorial, atenuando a premissa da relação entre este fenómeno e a redacção da obra original de Beato de Liébana - John Williams, "Purpose and imagery" [...], pp. 227 e 230.

73 Estima-se que a mensagem do Comentário fosse dirigida unicamente à comunidade monástica e aos pares de Beato, sendo assim visível a utilização de imagens e referências à vida monacal, familiares e apenas inteligíveis para estes leitores, oferecendo um conjunto de informação e «material» do texto bíblico, da literatura eclesiástica, dos Clássicos, que imperavam na experiência religiosa da Igreja ocidental deste período - Leslie G. FREEMAN, "Elementos simbolicos en la obra de Beato" [...], pp. 33 e 34; John WILLIAMS, "Purposes and imagery" [...], p. 227. 
Ana de Oliveira DiAs, Commentarium in Apocalypsin: o número e a forma geométrica na tradição simbólica das ilustrações do «Beato» de São Mamede de Lorvão

espiritual destas ilustrações e, consequentemente, da acção humana na criação ou destruição das mesmas.

Desta forma, permanecerão sempre num campo especulativo as verdadeiras intenções do autor ao conceber este texto literário, pois somente cerca de duzentos anos após a sua redacção original surgem subtis indícios do seu intuito, apresentadas por Maius — ilustrador da cópia de San Miguel de Escalada $[\mathbf{M}]$ referindo, no cólofon do códice, que havia «pintado uma série de imagens para as palavras maravilhosas das histórias, para que possam temer a chegada do julgamento do fim do mundo». ${ }^{74}$ Aqui coloca-se novamente a tónica sobre a questão da inexistência de um entendimento escatológico dos factos (defendida por Yves Christe), comprovando-se — por meio das próprias palavras deste copista- preocupações milenaristas ${ }^{75}$, mesmo em períodos em que, aparentemente, não se perspectivava o Escaton (como no século $X$, em que historicamente, não são conhecidas preocupações maiores deste carácter).

Procura-se, de igual modo, o fundamento para popularidade do Comentário nos séculos subsequentes, tal como para o continuado sentido da mensagem textual ou simbólica da obra. Temos notícia que a recepção literária, a partir do século X, ocorreu maioritariamente em contexto moçárabe - em mosteiros cristãos habitados certamente por monges que, por força dos eventos, se refugiaram a norte peninsular face à ameaça islâmica - sendo, assim, evidente a influência demarcada do Livro do Apocalipse no seio desta comunidade. Este facto manifestou-se, muito provavelmente, como reflexo da própria condição deste grupo, em constante sentido de alerta do ponto de vista cultural, religioso, anímico até, dada a constante eminência da deposição e abolição de um culto e rito que lhes era próprio. Toda esta questão suscitou um forte espírito de resistência, assente sobre as crenças salvíficas pela qual a comunidade moçárabe se caracterizou aos olhos da historiografia. O Apocalipse funcionaria assim como que um paralelo da sua condição social e espiritual, como que uma «válvula irradiadora das (suas) forças subconscientes». ${ }^{76} \mathrm{O}$ fím dos tempos, mesmo que não entendido no sentido quiliástico, preconizaria o término da vida terrena deste grupo - da sua visão religiosa, da sua Igreja - e, deste modo, desenvolveu-se a necessidade de um constante exercício de preparação para o advento do fim. De acordo com Henri Stierlin, a popularidade do Comentário ao Apocalipse no seio desta comunidade deveu-se à exaltação da ideia de resiliência e de combate, surgindo como uma das obras de maior inspiração para a Igreja Hispanica. ${ }^{77}$

A mensagem deste livro, e consequentemente do seu Comentário, constituiu assim uma importante força motriz para a comunidade cristã face às diversas

\footnotetext{
${ }^{74}$ John WILLIAMS, "Purposes and imagery “[...], pp. 222 e 226.

${ }^{75}$ Contudo, autores como Leslie. G. Freeman persistem na vinculação da obra de Beato com preocupações escatológicas, entendendo grande parte da simbologia presente na sua obra como mensagens deste teor - L. G. FREEMAN, "Elementos simbólicos en la obra de Beato" [...], p. 35.

${ }^{76}$ Expressão utilizada Henri Stierlin, p. 81.

${ }^{77}$ IDEM, ibidem, p. 81.
} 
Ana de Oliveira DiAs, Commentarium in Apocalypsin: o número e a forma geométrica na tradição simbólica das ilustrações do «Beato» de São Mamede de Lorvão

ofensivas, sejam internas, com a introdução de um rito reformista, ou externas, com o Islão, particularmente nas regiões de fronteira em período de Reconquista $^{78}$. Mesmo não apresentando reflexões directas sobre estas questões, a obra original de Beato viu a sua razão de ser nos seguintes cinco séculos, muito provavelmente, dado o espírito de instabilidade - geográfica, política, espiritual e de luta constante que se revelou a própria história da Península Ibérica até ao século XIII. Mais do que a ilustração dos «terrores do ano $800{ }^{79}$, do «ano mil» ${ }^{80}$, ou mesmo da predestinação da chegada da Sexta Idade (que se revelou distinta nos diversos cálculos numerológicos), o sentido do Comentário do Apocalipse expande-se para além do carácter escatológico ou eclesiológico, adquirindo, através das suas ilustrações, uma verdadeira dimensão anagógica, de interpretação das verdades divinas e de arrebatamento místico.

\section{O «Beato» de São Mamede de Lorvão: o códice e os contextos de produção}

O fenómeno de produção dos «Beatos» foi algo verificável e associado a uma geografia específica, sendo a Península Ibérica o berço e local de disseminação, por excelência, destes manuscritos, copiados e reinterpretados em diversos mosteiros locais, coincidindo, em muitas vezes, com fortes focos de resistência cristã face à ofensiva muçulmana. ${ }^{81}$ Em território portugalense temos prova e exemplo dessa mesma disseminação ${ }^{82}$, sob a forma de um único manuscrito ilustrado remanescente, produto dos finais do século XII, cópia do mosteiro de São Mamede de Lorvão. Reconhecido pelo carácter ímpar das suas iluminuras, este códice mereceu a atenção de diversos especialistas, já desde meados do século XIX, quando transladado por Alexandre Herculano para a Casa Forte do Arquivo Nacional da Torre do Tombo. ${ }^{83}$ Também Wilhelm Neuss, em discurso

${ }^{78}$ Em acordo com Henri Stierlin, a invasão muçulmana poderá ter fomentado um certo revivalismo em relação às perseguições sofridas pelos cristãos no Império romano, sendo evidente os paralelismos que podem ser traçados entre a primeira e a segunda realidade opressora. Como exemplos: Besta - Império Romano / Califado; Babilónia - Roma /Córdova, entre outros - Henri STIERLIN, p. 81.

${ }^{79}$ Título do artigo, anteriormente, citado Juan GIL, "Los terrores del año 800” [...].

${ }^{80}$ Sobre este assunto veja-se Georges DUBY, O Ano Mil, Lisboa, Edições 70, 2002.

${ }^{81}$ Jorge da Silva ROCHA, p. 65.

${ }^{82}$ Em território portugalense temos ainda notícia da existência de três cópias do Comentário ao Apocalipse. Para além do exemplar de Lorvão, conhecemos a versão não ilustrada de Alcobaça (Lisboa, ALC. 247) que seguiu o modelo laurbanense. Temos também notícia de um exemplar do século X, concedido ao mosteiro de Guimarães pela condessa Mumadona Dias, grande bibliófila que terá igualmente doado diversas obras para o armarium de Lorvão - Anne de EGRY, p. 30.

${ }^{83}$ Breve nota apensa ao códice, redigida pela mão de Alexandre Herculano aquando da transladação do manuscrito de Lorvão para o Arquivo Nacional: «Comentário ao Apocalipse, pelo monge Beato de Liébana, de quem existem várias cópias na Europa, feitas desde o IX até ao XIII. Esta é feita por um certo Egas em 1189 (era de 1227) como se lê na subscrição. O valor 
Ana de Oliveira DiAs, Commentarium in Apocalypsin: o número e a forma geométrica na tradição simbólica das ilustrações do «Beato» de São Mamede de Lorvão

na Universidade de Coimbra no final dos anos vinte, considerou o carácter destas iluminuras extremamente primitivo e infantil ${ }^{84}$, não as entendendo como provável cópia tardia de um exemplar primitivo ou de um modelo verdadeiramente antigo e quiçá mais próximo do arquétipo de Beato de Liébana.

Felizmente, novos olhares foram lançados sobre este manuscrito na tentativa de deslindar as múltiplas questões que este códice ainda encerra, de entre as quais, as reais circunstâncias -técnicas, estilistas, espirituais- que determinaram a produção de uma das obras que, unanimemente, reconhecemos como das mais importantes do património bibliográfico português.

\subsection{Mosteiro de São Mamede de Lorvão: apontamentos biográficos}

Reconstruir as origens do mosteiro de Lorvão ${ }^{85}$, da sua comunidade e, consequentemente, da sua produção livresca e artística constitui uma tarefa desafiante $^{86}$, porém delicada, uma vez que a ausência de documentação não nos permite reconstruir uma história precisa deste local e dos seus intervenientes no tempo, sendo com muita prudência que devemos procurar estabelecer os

deste códice está principalmente nas suas bárbaras iluminuras, onde se encontram muitos espécimes autênticos de trajos, alfaias, e arquitectura do século XII, raros em Portugal. Obtive-o das freiras do Lorvão em 1853, para o fazer depositar no Arquivo Nacional da Torre do Tombo, a quem fica pertencendo» - Anne de EGRY, p. 9.

84 «extremamente infantil (...) causa admiração encontrar no século XII e na Europa, um lugar onde se trabalha duma maneira tão primitiva.», foram as palavras que Wilhelm Neuss dedicou às iluminuras de Lorvão - Wilhelm NEUSS, O comentário ao Apocalipse de Lorvão e suas iluminuras, Coimbra, Faculdade de Letras da Universidade de Coimbra, 1929, p. 7. Autor que estabeleceu o primeiro stemma codicum dos «Beatos» (com base na tradição textual), visando assim compreender as diferentes filiações e relações entre os três ramos de cópias. Ao exemplar de Lorvão dedicou um pequeno estudo no qual se debruçou sobre as possíveis influências estilísticas deste manuscrito.

${ }^{85} \mathrm{Na}$ sua origem o mosteiro de Lorvão possuía dois oragos: São Mamede, pelo qual ficou conhecido, e São Pelayo (vulgarmente referido como São Paio), ambos santos mártires, c. 275 e 925, respectivamente. Aquando da passagem do mosteiro para domínio cisterciense, este foi dedicado à Virgem, redefinindo a sua nomeação, até aos dias de hoje, para mosteiro de Santa Maria de Lorvão.

${ }^{86}$ Deste modo, não é nossa pretensão uma reconstrução cronológica ou factual minuciosa da história do mosteiro de Lorvão, tão habilmente elaborada por autores como Aires Augusto do Nascimento, Maria João Branco, Nelson Correia Borges ou Mário de Gouveia. Visamos sim um subtil sublinhar de factos que consideramos chave para reconstruir um caminho imprescindível para a compreensão do nosso estudo. Sobre este assunto veja-se Aires Augusto do NASCIMENTO, "Mosteiro de Lorvão: A História possível dos seus tempos antigos", in Liber Testamentorum coenobii laurbanensis, (dir. de José FERNÁNDEZ CATÓN), vol. de estudos, Léon, Centro de Estudios e Investigación «San Isidoro» - Caja España de Inversiones - Archivo Histórico Diocesano, 2008, pp. 81- 156; Maria João BRANCO, "Reis, condes, mosteiros e poderes: o mosteiro de Lorvão no contexto político do reino de Leão (sécs. IX-XII)", in Liber Testamentorum coenobii laurbanensis [...], pp. 27-77; Nelson Correia BORGES, Arte monástica em Lorvão - sombra e realidade - das origens a 1737, vol I, Lisboa, Fundação Calouste Gulbenkian, 2002.; Mário de GOUVEIA, O limiar da tradição no moçarabismo conimbricense: os anais de Lorvão e a memória monástica do território de fronteira (sécs.XI e XII) (dissertação de mestrado apresentada à Faculdade de Ciências Sociais e Humanas da Universidade Nova de Lisboa), Lisboa, 2008 (texto policopiado). 
Ana de Oliveira DiAs, Commentarium in Apocalypsin: o número e a forma geométrica na tradição simbólica das ilustrações do «Beato» de São Mamede de Lorvão

parâmetros de análise e distinguir o que depende da «memória celebrativa», e o que de facto pertence à história e às verdadeiras raízes deste mosteiro. ${ }^{87}$

Situado nas proximidades de Coimbra - no actual concelho de Penacovaentre esta cidade e o "caminho de Viseu», encontrávamos o mosteiro de São Mamede de Lorvão ${ }^{88}$, comunidade fundada num vale eremítico — dita «Cova dos Loureiros $»{ }^{89}$ - junto a um dos cursos principais do rio Mondego. Este mosteiro sofreu, e beneficiou, das vicissitudes históricas desta região, que determinaram irremediavelmente o modus vivendi e operandi desta comunidade «comprimida» entre a frente de guerra contra a ofensiva islâmica e a grande cidade coimbrã: aceso foco irradiador de cultura moçárabe. ${ }^{90}$

Fundado, crê-se, em meados do século $\mathrm{IX}^{91}$, estimamos que os primórdios desta casa monástica tenham sido dedicados à instauração de um culto de edificação e prática de uma vida espiritual inspirada nos textos patrísticos, caracterizadores da tradição do monaquismo hispânico, apoiado numa pluralidade de regras: regula mixta. ${ }^{92}$ A primeira referência à regra de São Bento

${ }^{87}$ Sobre este assunto veja-se Aires Augusto do NASCIMENTO, "Mosteiro de Lorvão: A História possível dos seus tempos antigos [...], pp. 81-156.

${ }^{88}$ Nelson Correia BORGES, p. 37. Neste estudo é lançado um olhar atento e sistemático sobre a história do mosteiro de Lorvão, desde os seus primórdios à primeira metade do século XVIII. O autor revisita os factos históricos e a arte então produzida no seu seio, sendo, porém, ligeira a apreciação e incidência sobre o período beneditino, tal como sobre os códices literários então produzidos.

${ }^{89}$ IDEM, ibidem, p. 52. Apesar de não ser entendido como um topónimo consensual. Veja-se anexo iconográfico, Fig. 37.

${ }^{90}$ Sobre este assunto veja-se Mário de GOUVEIA, que neste estudo, com base nos anais do mosteiro de Lorvão (reflectores da preservação da memória monástica), visou perscrutar as relações e os reflexos entre a (irradiante) tradição moçárabe conimbricense e a realidade laurbanense nos séculos XI e XII. Esta constitui uma importante análise para um maior (e mais amplo) entendimento do modus operandi desta comunidade monástica e da sua experiência da religiosidade, considerando, porém, como refere o autor, os «múltiplos e controversos posicionamentos historiográficos» que ainda hoje devemos considerar (cautelosamente) quando procuramos o conhecimento da história monástica de Lorvão - IDEM, ibidem, p. 305.

${ }^{91}$ O documento mais antigo presente no Liber Testamentorum é um diploma do rei Ordonho I, dirigido ao abade Justo do mosteiro de Lorvão no ano de 877. Contudo, a análise do diploma revela um erro na transcrição para o cartulário, pois, de acordo com Rui de Azevedo, este só poderá ser um documento de Ordonho II que governou na Galiza desde 911, não constituindo, este documento, um indicador seguro da real ancianidade deste mosteiro. Sobre este assunto veja-se Ruy de AZEVEDO, O mosteiro de Lorvão na Reconquista cristã, Lisboa, 1933, pp. 20 e 21.

${ }^{92}$ Sobre este assunto veja-se José MATTOSO, "O Monaquismo Ibérico e Cluny", in Religião e cultura na da Idade Média portuguesa, Lisboa, Imprensa Nacional - Casa da Moeda, 1997, pp. 55-72. No mosteiro de Lorvão verificámos igualmente uma tradição de regra communis (contrariando a sugestão de Frei Bernardo de Brito ao procurar uma filiação beneditina desde os seus primórdios - Aire Augusto do NASCIMENTO, "Mosteiro de Lorvão: A História possível dos seus tempos antigos" [...], pp. 95-96 e 102) na qual se inspirou, profundamente, o monaquismo frutuosiano que influenciou, de forma determinante, a vida religiosa no condado e 
Ana de Oliveira DiAs, Commentarium in Apocalypsin: o número e a forma geométrica na tradição simbólica das ilustrações do «Beato» de São Mamede de Lorvão

em Lorvão surge apenas em $1101^{93}$, quando confiamos que se encontrava já em caminho da sua instituição. ${ }^{94}$ Contudo, temos indícios de que o novo costume monástico fora recebido com certa animosidade por parte desta comunidade, que pareceu demonstrar uma resistência cultural até ao fim, frente ao opositor estrangeiro, portador do rito romano. ${ }^{95}$ Evidência dessa constante resistência cultural e identitária por parte da comunidade de Lorvão foi precisamente a cópia de diversas obras (numa cronologia próxima), que sabemos comprometidas com a tradição hispânica, da qual estes monges se consideravam descendentes e cultores; referimo-nos pois ao exemplar do Passionarium Hispanicum, ou à obra que nos ocupa, o Commentarium in Apocalypsin de Beato de Liébana. ${ }^{96}$

Apesar da penumbra que paira sobre a biografia deste mosteiro temos, porém, notícias, mais ou menos dispersas, do progressivo crescimento em importância e influência, da discreta comunidade monástica ao longo dos tempos. O século XII, período marcado por tensões, conflitos e transformações decisivas (políticas e espirituais) ${ }^{97}$ revelou-se determinante para a sua História. Para além dos diversos benefícios que Lorvão progressivamente passara a auferir por parte da nobreza condal, particularmente da família dos condes de Coimbra ${ }^{98}$, assistimos a um

nas regiões da Galiza até, sensivelmente, o século XI - José MATTOSO, "Sobrevivências do monaquismo frutuosiano em Portugal durante a Reconquista" [...], pp. 11-27.

93 IDEM, ibidem, pp. 103-104. Em 1103 temos notícia que Maurício Burdino, bispo de Coimbra, outorga a igreja de Santa Justa, na mesma cidade, a Hugo de Cluny e aos seus monges. Esta questão (em relação com o documento de Lorvão que refere, em 1101, a presença do culto beneditino no seu seio) atesta a plausibilidade da sua instituição, sem que contudo signifique um enquadramento exclusivo ou de carácter cluniacense. Crê-se que a mudança de observância terá sido verificada no período de restauração do mosteiro sob a administração do abade Eusébio (1085-1109) - Jorge da Silva ROCHA, p. 72.

${ }^{94}$ Aires Augusto do NASCIMENTO, "Mosteiro de Lorvão: A História possível dos seus tempos antigos [...], p. 103.

${ }^{95}$ IDEM, ibidem, pp. 104 e 107. Aires Augusto do Nascimento afirma ainda que a extinção definitiva desta comunidade monástica, no século XIII, poderá ter tido origem no seu carácter rebelde face à aceitação de uma reforma regular, visível através das constantes tentativas de perpetuação das suas raízes tradicionais.

${ }^{96}$ IDEM, ibidem, pp. 107-108.

${ }^{97}$ Período marcado por tensões políticas relacionadas com o sentimento de independência do condado, não somente frente à ameaça externa muçulmana, como face às disputas de independência dos reinos cristãos do Norte. Também a nível espiritual caracterizou-se pelo processo de desaparecimento do monaquismo ibérico face à introdução da regra beneditina e do rito romano que, anteriormente, referimos, Jorge da Silva ROCHA, pp. 70,71.

${ }^{98} \mathrm{~A}$ título de exemplo, os diversos benefícios atribuídos por Afonso Henriques, primeiro rei portugalense, que em 1133 couta o mosteiro de Sperandei a favor de Lorvão, assim como as vilas de Sabugosa, Treixedo e Midões. Em 1174 doou Verba e Perrães; em 1176 também o Tabueiro e o canal de Abrantes, no rio Mondego, entre outros - Aires Augusto do NASCIMENTO, "Mosteiro de Lorvão: A História possível dos seus tempos antigos" [...], p. 149. Sobre este e outros benefícios outorgados ao mosteiro de Lorvão em períodos anteriores veja-se Ruy de AZEVEDO, pp. 23-36 e Mário de GOUVEIA, pp. 160-188. Sobre este assunto veja-se ainda Maria João BRANCO, pp. 27- 77. 
Ana de Oliveira DiAs, Commentarium in Apocalypsin: o número e a forma geométrica na tradição simbólica das ilustrações do «Beato» de São Mamede de Lorvão

período de consolidação e reestruturação, levadas então a cabo pelo abade Eusébio, face às depredações muçulmanas sobre a zona de Coimbra.

Em 1118, após a morte do mesmo abade, o mosteiro de Lorvão demostrou um forte crescimento económico. A cidade de Coimbra passa a constituir o coração do condado, marcada pela criação do mosteiro de Santa Cruz de Coimbra, assim como pela mudança da corte de Guimarães para esta cidade. Não obstante, o mosteiro de Lorvão continuou a demonstrar um progressivo desenvolvimento, sem grandes repercussões face ao crescimento exponencial do mosteiro crúzio. Entre 1162 e 1192, sob a regência do abade João, assistimos ao apogeu desta instituição, marcado por uma intensa produção artístico-literária, possibilitada certamente pelo estado de graça económica que então se verificava. ${ }^{99}$ A cópia do Comentário ao Apocalipse é precisamente um produto deste período tão notável na história do mosteiro de Lorvão; período esse em que parecer ter sido um dos scriptoria mais profícuos do território portugalense.

Contudo, aquando da viragem do século, e após um longo e vincado período de resistência, o grupo monástico foi, na perspectiva de Aires do Nascimento ${ }^{100}$, vencido nas suas convicções tradicionais e inexoravelmente extinto, dando início a um novo período na história deste mosteiro: a ocupação feminina, sob o voto cisterciense, que viu somente o seu término a 3 de Julho de 1887 , por morte da última religiosa D. Luísa Madalena de Sousa Tudela. Glorificamos, deste modo, os evidentes esforços que comunidade feminina exerceu, ao longo dos tempos, para a defesa e conservação das obras enaltecedoras das memórias e da antiguidade da história deste mosteiro. ${ }^{101}$

\subsection{O «Beato» laurbanense: apontamentos codicologicos}

O Comentário ao Apocalipse copiado no mosteiro de Lorvão é uma das cópias que, notavelmente, nos oferece informação, directa ou indirectamente, acerca da sua datação e origem. Ao contrário da grande maioria dos exemplares $\operatorname{conhecidos}^{102}$, este «Beato» apresenta no seu colofón tanto o ano de produção,

\footnotetext{
${ }^{99}$ Jorge da Silva ROCHA, p.74.

${ }^{100}$ Aires Augusto do NASCIMENTO, "Mosteiro de Lorvão: A História possível dos seus tempos antigos $[\ldots]$.

101 Actualmente ainda são visíveis e conhecidos os esforços exercidos pela comunidade feminina de Lorvão para a salvaguarda do seu património monástico face aos irremediáveis ditames da história e do tempo. Em comunicação pessoal com Inês Correia (conservadora de manuscritos do Arquivo Nacional da Torre do Tombo) pudemos observar uma das técnicas a que estas monjas recorreram para a conservação das iluminuras de alguns dos manuscritos medievais e modernos deste fundo. Por meio da aplicação de pequenos quadrados de tecido (cosidos no pergaminho) sobre as ilustrações (essencialmente iniciais ornadas), foi possivel a conservação dos pigmentos e da qualidade (quase) original destas iluminuras. Facto que demonstra os extremos cuidados que estes manuscritos mereceram às mãos das cistercienses de Lorvão que, a posteriori, confiaram o Comentário laurbanense a Alexandre Herculano, para que este permanecesse em segurança.

${ }^{102}$ De acordo com Anne de Egry, nenhuma outra cópia conhecida do século XII se encontra datada. Este facto pode evidenciar uma possível relação da cópia de Lorvão com um modelo
} 
Ana de Oliveira DiAs, Commentarium in Apocalypsin: o número e a forma geométrica na tradição simbólica das ilustrações do «Beato» de São Mamede de Lorvão

como o nome do copista, factores estes determinantes para o estudo e análise de todo o seu contexto de produção. No cólofon do manuscrito observamos, então, a seguinte referência: Iam liber est scriptus. qui scripsit sit benedictus ERA MCCXXVII. ego EGEAS qui hunc librum scripsi si aliquibus a recto tramite exiui. ${ }^{103}$ Filia-se, portanto, ao ano de 1189, tendo sido elaborado por Egeas ou Egas $^{104}$, possível monge copista do scriptorium de Lorvão, nome que não é de todo desconhecido no panorama ibérico, de acordo com Peter Klein. ${ }^{105}$ No entanto, esta subscrição não se revela informativa quanto ao centro de produção da obra. Apenas por meio de análises e paralelismos estilísticos, com cópias do mesmo fundo, como o caso de De avibus ${ }^{106}$, foi possível apurar com maior segurança a origem deste manuscrito. ${ }^{107}$

Materialmente, é constituído por um conjunto de duzentos e dezanove fólios em pergaminho, certamente em pele de cordeiro ${ }^{108}$ com cerca de $340 \times 247 \mathrm{~mm}$. Estes terão sido encurtados a posteriori, cremos que em $12 \mathrm{~mm}^{109}$, um aspecto que felizmente não inviabiliza o estudo das regras da «mise-en-page»" ${ }^{10}$

mais antigo da tradição dos «Beatos», no qual os elementos data/autor constituiriam certamente pontos referenciais no cólofon do manuscrito - Anne de EGRY, p. 36

${ }^{103}$ BEATO DE LIÉBANA, Commentarium in Apocalypsin; cópia ilustrada do Mosteiro de São Mamede do Lorvão. DGARQ/ANTT, Ordem de Cister, Mosteiro de São Mamede do Lorvão, Livro 44 (C.F. 160), fl. 219v. Sobre este assunto veja-se Jonh Wlliams, The Lorvão Beatus (L)", in John WILLIAMS, The illustrated Beatus. A corpus of the illustrations of the Commentary on the Apocalypse, vol. V (The 12th and 13th Centuries), London, Harvey Miller Publishers, 1994, p. 31.

${ }^{104}$ Sobre o nome do copista veja-se Anne de EGRY, p. 29.

${ }^{105}$ Peter KLEIN, Beato de Liébana: la ilustración de los manuscritos de Beato y el Apocalipsis de Lorvão (trad. Beatriz Mariño), Valencia, Patrimonio Ediciones, 2004, p. 23.

${ }^{106}$ IDEM, ibidem, p. 26.

${ }^{107}$ Contudo, alguns especialistas como Saul Gomes, em comunicação para o Seminário "MSML Percurso de um fundo monástico - do Mosteiro de Lorvão ao ciberespaço", no Arquivo da Universidade de Coimbra, a 31 de Março de 2011, reforçam as dúvidas quanto ao local de produção desta cópia, considerando que os paralelismos estilísticos podem revelar-se incipientes para uma atribuição inequívoca a este scriptorium.

${ }^{108} \mathrm{O}$ estado actual em que o códice se encontra revela um pergaminho de qualidade medíocre, denotando igualmente diversas marcas da recorrente utilização deste manuscrito ao longo dos tempos - Peter KLEIN, Beato de Liébana: la ilustración [...], p. 15.

${ }^{109}$ Foi possível apurar a medida do encurtamento por comparação com o fragmento do mappamundi do mesmo manuscrito, que corresponde ao tamanho original do códice - Anne de EGRY, p. 32 .

110 José RUÍZ ASENCIO, "Los copistas de Liber Testamentorum", in Liber Testamentorum coenobii laurbanensis [...], pp. 193-242, ref. p. 198. Ao citar o Comentário ao Apocalipse de Lorvão, o autor afirma que o encurtamento verificado nos fólios deste manuscrito constitui hoje um prejuízo para o conhecimento mais profundo das suas regras de «mise-en-page». Contudo, este fenómeno não se revela prejudicial para o entendimento desta técnica, no tocante à inserção da informação gráfica e textual num espaço, pois esses elementos não se encontram comprometidos após esta reformulação. A remoção de $12 \mathrm{~mm}$ (acção que adveio, muito 
Ana de Oliveira DiAs, Commentarium in Apocalypsin: o número e a forma geométrica na tradição simbólica das ilustrações do «Beato» de São Mamede de Lorvão

aplicadas no manuscrito. ${ }^{111}$ Contudo, a isto devido, a informação quanto ao número dos cadernos, tal como algumas glosas marginais conservam-se apenas parcialmente. Os fólios encontram-se tendencialmente organizados em grupos de quatro bifólios, obtidos por meio da dobragem da pele in-quarto. ${ }^{112}$

Do ponto de vista textual, este encontra-se redigido em latim, tendo sido o texto dividido em duas colunas de vinte e nove linhas, redigidas em escrita carolina de transição. A homogeneidade verificável na redacção sugere-nos também que esta obra tenha sido efectuada somente por uma única mão experiente na arte da cópia, que fez uso essencialmente dos pigmentos pretos e vermelhos (empregue em iniciais, epígrafes ou linhas de particular relevância) aquando da copia textual deste códice.

O carácter ritual deste manuscrito, tal como a sua constante utilização é igualmente visível através das referidas glosas (ou textos marginais) que sobreviveram à reencardenação deste códice no século XVI —algumas destas glosas encontram-se redigidas em latim, mas também em português do século XVI - revelando-se indicadores da continuada utilização do próprio manuscrito ${ }^{113}$ ao longo dos tempos. ${ }^{114}$

O número de ilustrações é, de igual modo, um aspecto variável entre os diferentes «Beatos». O caso de Lorvão constitui precisamente um exemplar parcial, tendo apenas sido copiado o Apocalipse de São João e algumas ilustrações do respectivo Comentário. É assim composto por setenta storiae, acompanhadas de setenta fólios ilustrados: dezoito ilustrações de página inteira, vinte de meia página e vinte e oito de dimensões inferiores. Contabilizamos ainda o desenho geométrico dos Sete selos (fólio 134) para efeitos do presente estudo. ${ }^{115}$

Em torno da autoria destas imagens, muitos historiadores levantam a hipótese de que Egeas terá sido copista e ilustrador do exemplar laurbanense ${ }^{116}$, contudo, de acordo com Klein, esta teoria não se confirma se partirmos do pressuposto que

provavelmente, de um restauro posterior) pode sim impossibilitar o conhecimento exacto da dimensão das margens de códice (também estas pré-definidas pelas regras da «mise-en-page»).

${ }^{111} \mathrm{O}$ «Beato» de Lorvão revela uma filiação à estrutura codicológica visigótica atestada pelas suas próprias dimensões. Tendencialmente mais imponentes, os códices visigóticos chegavam a alcançar os $300 \mathrm{~mm}$, aspecto que foi contrariado pelo universo de produção carolino, José RUIZ ASENCIO, p. 198.

${ }^{112}$ Relativamente à análise codicológica veja-se Horácio Augusto PEIXEIRO, Um olhar sobre a iluminura do Apocalipse do Lorvão, (Prova científica e técnica para Prof. Coordenador do Instituto Politécnico de Tomar), Tomar, 1998.

${ }^{113}$ Peter KLEIN, Beato de Liébana: la ilustración [...], p. 18.

${ }^{114}$ BEATO DE LIÉBANA, Commentarium in Apocalypsin; cópia ilustrada do Mosteiro de São Mamede do Lorvão. DGARQ/ANTT, Ordem de Cister, Mosteiro de São Mamede do Lorvão, Livro 44 (C.F. 160), fls. 12 e 17.

${ }^{115}$ Anne de EGRY, p.35.

116 Anne de Egry procura ao longo da sua análise sugerir um mesmo autor para ambos os ofícios. Advoga que o texto e a ilustração terão sido elaborados simultaneamente, dada a visível orgânica entre ambas as partes e a sua mútua acomodação, Anne de EGRY, pp, 32 e 33. 
Ana de Oliveira DiAs, Commentarium in Apocalypsin: o número e a forma geométrica na tradição simbólica das ilustrações do «Beato» de São Mamede de Lorvão

Egeas nunca se afirmou como tal, como foi prática corrente de outros miniaturistas como Maius - do mosteiro de San Miguel de Escalada- ou mesmo Obeco, ilustrador da cópia de Valladolid. ${ }^{117}$ Também o paralelismo estabelecido entre a letra do texto e a dos pequenos tituli das miniaturas demonstra que estas últimas procedem de uma mão com menos destreza e regularidade caligráfica. ${ }^{118}$ Peter Klein salienta ainda a plausibilidade das iluminuras não pertencerem a um único autor, dada a diferenciação técnica que é passível de ser reconhecida em diferentes momentos do códice. ${ }^{19}$

Do ponto de vista textual e pictórico, o «Beato» de Lorvão $[\mathbf{L}]$ integra-se, deste modo, na família I, de acordo com os stemmata codicum de Wilhelm Neuss e Peter Klein, encontrando-se assim ligado a uma tradição extremamente específica das quais fazem parte os exemplares considerados seguidores de uma tradição mais antiga, como os casos do Fragmento de Silos [Fc], do Ms. Vitr. 14$1\left[\mathbf{A}^{1}\right]$, Escorial $[\mathbf{E}]$, de San Millán de Cogolla $\left[\mathbf{A}^{2}\right]$, Burgos de Osma $[\mathbf{O}]$, Corsini $[\mathbf{C}]$, Fragmento de Léon [Fa] e Navarra $[\mathbf{N}]$.

\subsection{O scriptorium-panorama de produção literária: relaç̃̃es e influências no século XII}

Pouco conhecemos sobre produção de manuscritos no período românico e préromânico portugalense. A realidade a que temos acesso hoje em dia é radicalmente fragmentária, e este factor afasta-nos não apenas do conhecimento das produções literárias e artísticas, como também da história, das influências e do modus operandi dos scriptoria de então.

Actualmente, consideramos quatro mosteiros aos quais associamos os fundos sobreviventes: Santa Cruz de Coimbra, Santa Maria de Alcobaça, São Mamede de Lorvão e São Pedro de Arouca, não nos sendo permitido, porém, um estudo de conjunto profundo do panorama da iluminura românica portuguesa. Todavia,

117 São conhecidos casos em que por vezes os scriptoria monásticos recorriam a artistas externos à comunidade, como leigos, para a concepção das ilustrações dos códices (como figura num dos fólios do Manuscrito de Copenhaga, Kongelige Bibliotek, s. 4.2. ${ }^{\circ}$ ). Estes executavam a tarefa subordinados ao programa iconográfico e iconológico estabelecido pelos responsáveis do scriptorium, Aires Augusto do NASCIMENTO, "O "scriptorium" medieval, instituição matriz do livro", in A iluminura em Portugal. Identidade e Influências [...], pp. 53-108, ref. pp. 75 e 83.

${ }^{118}$ Peter KLEIN, Beato de Liébana: la ilustración [...], pp. 23-24.

${ }^{119}$ IDEM, ibidem, p. 24. O autor sugere uma diferenciação entre ambos os ilustradores com base na destreza técnica, considerando que um primeiro demonstra uma maior qualidade no desenho, particularmente no pormenor dos rostos. O segundo responsável por este ofício, autor da grande maioria das ilustrações, revela uma menor habilidade e incorre na deformação do conteúdo iconográfico. Peter Klein interpretou esta questão como falha do miniaturista, que terá feito uma associação visual incorrecta da história representada e assim, por tais erros, revoga a possibilidade do escriba e o iluminador constituírem a mesma pessoa. Por seu lado, John Williams assume uma posição distinta, afirmando que existem fortes indícios para considerar o texto e a iluminura produtos de um mesmo autor, John WILLIAMS, "The Lorvão Beatus (L)" [...], pp. 31-32. Colocamos, porém, a questão se estas incoerências iconográficas consistem, efectivamente, apanágio da cópia laurbanense ou se esta segue um modelo anterior que evidenciava já estas características, hipótese que necessariamente obrigaria a um novo olhar sobre a concepção deste códice. 
Ana de Oliveira DiAs, Commentarium in Apocalypsin: o número e a forma geométrica na tradição simbólica das ilustrações do «Beato» de São Mamede de Lorvão

visando contrariar esta realidade, novos olhares têm vindo a ser lançados sobre a história e os possíveis discursos operativos dos scriptoria medievais portugueses, procurando reconstruir não somente as eventuais dinâmicas de correspondência entre mosteiros, como a própria história material das suas oficinas: tipologias de códices, técnicas e análise de pigmentos. ${ }^{120}$ É precisamente neste período que vemos florescer aquele que foi considerado um dos scriptoria monásticos mais importantes neste contexto: ${ }^{121}$ São Mamede de Lorvão. As obras remanescentes deixam-nos, então, adivinhar uma profícua produção de manuscritos, que para além da lavra de carácter notarial e económico - como o importante cartulário do mosteiro Liber testamentorum coenobii laurbanensis - produziu também obras espirituais incomparáveis no nosso panorama. Hoje, o produto sobrevivente deste fundo encontra-se à guarda do Arquivo Nacional da Torre do Tombo, sendo, porém, considerado como que a «ponta de um grande iceberg»» ${ }^{122}$ do que terá constituído a produção deste scriptorium durante século XII. ${ }^{123}$ Do período em questão - época áurea da iluminura românica portuguesa - conhecemos cerca de cinco códices literários afectos a este centro, dos quais quatro espelham essa importante relação e filiação às tradições ibéricas. Destacamos então um saltério dos inícios do século XII, com cerca de cento e cinquenta e seis fólios, em letra carolina; um leccionário -incorrectamente designado Martirológio de Lorvão, códice de datação imprecisa (estima-se que entre 1176-1200) ${ }^{124}$, constituído por cerca de duzentos e dezoito fólios em letra carolina; o De avibus, datado de 1183, que apresenta cerca de noventa fólios em letra carolina, e que apesar de constituir cópia ilustrada de De bestiis et aliis rebus atribuído a Hugue de Fouilloy (redigido neste mesmo século e trazido, pouco tempo depois, para o ocidente peninsular ${ }^{125}$, congrega também a De creatione hominis de Isidoro de Sevilha.

${ }^{120}$ Ressalvamos os esforços que o Instituto de Estudos Medievais da Universidade Nova de Lisboa (em parceria com o núcleo de Conservação e Restauro da mesma universidade) tem vindo a desenvolver em torno dos principais scriptoria monásticos portugalenses, procurando encetar uma análise, essencialmente material, que nos atribua pistas sobre o modus operandi destas instituições. Estes resultados têm sido apresentados em diversos colóquios internacionais, relacionados com o estudo da cor e dos pigmentos na iluminura portuguesa. Também nesta mesma universidade salientamos o projecto de doutoramento de Inês Correia - intitulado Iconografia e Arqueologia dos códices medievais no fundo laurbanense - que cremos que irá constituir um importante contributo para o conhecimento mais profundo das práticas do scriptorium de Lorvão.

\footnotetext{
${ }^{121}$ Maria João BRANCO, p. 29.

122 José Manuel RUIZ ASENCIO, p. 195.

${ }^{123}$ Para além da incontornável voragem dos tempos face à qual perdemos diversos documentos históricos, em 1055 no Concílio de Coyanza, muitos dos livros litúrgicos foram banidos pela introdução do rito romano, sendo muitos destes votados à obliteração pelo fogo, como sugerem as crónicas - Aires Augusto do NASCIMENTO, “A Iluminura hispânica primitiva: fragmentos de um universo cultural" [...], p. 114.

${ }^{124}$ Datação proposta por Jorge da Silva ROCHA, p. 76.

${ }^{125}$ Esta questão comprova as estreitas ligações e relações entre os mosteiros portugalenses e os centros de cultura além-Pirenéus, Nelson Correia BORGES, pp. 95 e 96.
} 
Ana de Oliveira DiAs, Commentarium in Apocalypsin: o número e a forma geométrica na tradição simbólica das ilustrações do «Beato» de São Mamede de Lorvão

Ambos encontram-se datados e atribuídos, no respectivo colofón, ao scriptorium do mosteiro de Lorvão. Ressalvamos, ainda, em relação a este manuscrito que a primeira parte, referente a De Avibus, apresenta a marca de autoria, apresentando como copista o nome Magister. ${ }^{126}$ Sublinhamos ainda as importantes Enarrationes in Psalmos de Agostinho de Hipona, divididas em dois códices datados de 1184 . $^{127}$ Ultimando o presente grupo, destacamos o Comentário ao Apocalipse, de Beato de Liébana, datado de 1189 que, por meio de paralelismos estilísticos e técnicos (como anteriromente referida análise de pigmentos utilizados), permitiu intuir, com maior efeito, o centro de produção desta cópia.

Assistimos então à época áurea do scriptorium laurbanense, tendo notícia que no último quartel do século XII, este mosteiro terá seguramente experimentado um período próspero, de grande estabilidade económica, testemunhável por meio da volumosa actividade cultural que deixou transparecer ${ }^{128}$ até sensivelmente os anos de 1205-1206, assinalados pela expulsão dos monges negros desta abadia. ${ }^{129}$

\section{Circulação de modelos e manuscritos}

A natural proximidade geográfica entre os três grandes scriptoria portugalenses - Santa Cruz de Coimbra, Santa Maria de Alcobaça e São Mamede de Lorvão - afectou, inevitavelmente, o panorama das suas produções. A relação entre as semelhanças e as disparidades dos conteúdos artístico-literários são pontos auxiliares para a tentativa de uma reconstrução da identidade cultural e artística destes monges beneditinos, e do modo como este mosteiro se revelou tão sui generis na sua produção material. ${ }^{130}$

Ao contrário de Santa Cruz e de Alcobaça, com reconhecidos vínculos institucionais com França ${ }^{131}$, a casa de Lorvão, pela sua antiguidade e raízes

\footnotetext{
${ }^{126}$ Peter KLEIN, Beato de Liébana: la ilustración [...], pp. 25 e 26.

${ }^{127}$ Nelson Correia BORGES, pp. 94-97.

${ }^{128}$ A par dos tesouros monásticos reservados à eucaristia, como cálices e outros objectos rituais, o livro foi considerado dos bens mais preciosos e luxuosos de uma casa religiosa. A proficiência de um mosteiro poderia ser visível por meio da actividade do seu scriptorium e dos materiais e obras produzidos. A execução de um códice constituía um grande empreendimento financeiro dados os diversos materiais (por vezes exóticos) necessários à sua concepção, como a pele de animal para o pergaminho ou os pigmentos para a iluminura, sendo muitos destes elementos somente obtidos por meio de importação. Concomitantemente, os meios humanos, fossem estes religiosos ou leigos, exigiam gastos ou dispensas dos ofícios litúrgicos para o novo exercício espiritual. No caso de Lorvão a vaga de produção de códices litúrgicos constatada na segunda metade do século XII constitui prova cabal do estado de temporária plenitude económica neste mosteiro, Aires Augusto do NASCIMENTO, "O “scriptorium” medieval [...], pp. 66 e 75.
}

\footnotetext{
${ }^{129}$ Peter KLEIN, Beato de Liébana: la ilustración [...], p.28.

${ }^{130}$ Sobre este assunto veja-se Maria Adelaide MIRANDA, "A iluminura românica em Portugal" [...], pp. 127-142, ref. pp. 129 e 146; veja-se Jorge da Silva ROCHA, p. 80.

${ }^{131}$ Santa Cruz de Coimbra, sob regência dos cónegos regrantes, foi buscar influência aos modelos iniciais do sul de França (regiões da Aquitânia e Languedoc). Por seu lado, o mosteiro de Alcobaça filiou-se, essencialmente, a modelos setentrionais - influência de Claraval e dos mosteiros da Borgonha. Sobre este assunto veja-se Maria Adelaide MIRANDA, "A iluminura românica em Portugal" [...], p. 139.
} 
Ana de Oliveira DiAs, Commentarium in Apocalypsin: o número e a forma geométrica na tradição simbólica das ilustrações do «Beato» de São Mamede de Lorvão

incertas, não nos permite apurar vínculos monásticos concretos, para além da sua dependência eclesiástica da Sé de Coimbra em determinados momentos da sua história, aspecto esse que influenciou e condicionou determinantemente a vivência deste mosteiro. ${ }^{132}$

A relação entre estes três scriptoria constitui destarte um factor evidente, como de resto podemos compreender através das cópias do supracitado $D e$ avibus, uma obra transversal a estas comunidades monásticas, num período próximo. A sobrevivência destes manuscritos permitiu, assim, apurar a possível derivação de um modelo comum, hoje desconhecido, de origem francesa, aspecto este que reforça a ideia de um sistema de «passagem de testemunho», e de partilha de influências quanto a temas literários e iconográficos, somente divergente no tocante ao estilo e à técnica da ilustração. ${ }^{133}$ O sriptorium de Lorvão marca então a sua individualidade estilística pela simplicidade e estilização formal, pela ênfase da linha e da estrutura em detrimento de uma decoração profusa, em que a figura humana se demonstra reminiscente das figurações de um Cristianismo primitivo, na sensação de um arcaísmo deliberado $^{134}$. Também a cor é um elemento chave. No exemplo supracitado do De Avibus é observável uma menor área pintada em relação às restantes cópias, parecendo-nos ser esta uma tendência indelével deste scriptorium: uma marcada diferença na aplicação e uso da cor em relação aos seus contemporâneos hispânicos.

Deste modo, a antiguidade deste mosteiro, juntamente com o aparente desejo de preservação da tradição ibérica por parte desta comunidade, pode constituir um reflexo intencional da procura de modelos ilustrativos também mais antigos, visando um certo revivalismo, assim como a perpetuação dos textos e dos cânones estilísticos hispânicos, sendo estes monges, por certo, fortemente influenciados pela própria região em que o mosteiro se implantava: grande foco da cultura moçárabe, opositora resistente ao proselitismo do rito reformista e partidária persistente de um sistema cultural e mental assente na correlação entre o tempo histórico e a memória ${ }^{135}$, num constante exercício de retorno às formas literárias tradicionais. No entanto, como referiu Adelaide Miranda, a influência de Santa Cruz fez-se sentir de igual modo neste scriptorium com a abertura de portas a discretas, porém importantes, a influências francesas, caracterizadoras de um compromisso, por parte de Lorvão, entre as tradições ibéricas ${ }^{136}$ e o produto de uma segunda fase de influência cultural francesa. ${ }^{137}$

\footnotetext{
${ }^{132}$ Peter KLEIN, Beato de Liébana: la ilustración [...], p. 30.

${ }^{133}$ IDEM, ibidem, p. 30. Sobre as relações entre os scriptoria românicos portugalenses veja-se Maria Adelaide MIRANDA, “A iluminura românica em Portugal” [...], p. 137.

${ }^{134}$ Anexo iconográfico, Figs. 38 e 39.

${ }^{135}$ Mário de GOUVEIA, p. 92.

136 Adelaide Miranda sugere que, dada a situação geográfica de fronteira do mosteiro laurbanense (e dada a próprio modelo espiritual seguido em Lorvão), a cópia do Comentário ao Apocalipse terá constituído uma reprodução de um modelo moçárabe, tendo em conta, porém,
} 
Ana de Oliveira DiAs, Commentarium in Apocalypsin: o número e a forma geométrica na tradição simbólica das ilustrações do «Beato» de São Mamede de Lorvão

Constatamos também que já no século IX, com o crescimento em importância do mosteiro de Lorvão, contactos mais estreitos foram estabelecidos com o reino asturo-leonês, intensificados com o avanço da «Reconquista». Esta realidade terá ditado, certamente, uma cadência relacional entre os mosteiros beneditinos desta região, promovendo uma ligação e partilha espiritual mais estreita, pautada pelo empréstimo de obras de auctoritates bastante procuradas na tradição litúrgica. ${ }^{138}$ Desconhecemos, no entanto, uma conexão directa além-Pirenéus, mesmo após a reforma cluniacense ${ }^{139}$ que, de forma discreta, parece ter tocado neste mosteiro. Foi de facto nos finais do século XI, e inícios da centúria seguinte, que a influência francesa se fez sentir com maior intensidade por todo o reino de Leão $^{140}$, tornando-se um foco transmissor de influências até ao extremo ocidental da Península.

Posto isto, podemos conjecturar uma transmissão de influências francófonas (de modo indirecto) via Leão, ou mesmo via Santa Cruz de Coimbra, mosteiro que mantinha estreitos laços com o São Rufo de Avinhão. O scriptorium de Lorvão destaca-se então pela evidente procura de demarcação enquanto comunidade monástica depositária de uma longa tradição hispânica, e reflectora do diálogo desta mesma para com os elementos externos - muçulmano e centroeuropeu- que, por duas frentes distintas, colidiram com o «rochedo» laurbanense, que se revelou fiel a si mesmo, mas dialogante com as influências exógenas. ${ }^{141}$ Assim, esta realidade - associada a um período de efervescência cultural - terá certamente originado uma dinâmica de circulação (e empréstimo) de homens e manuscritos, quiçá um tanto à semelhança do que adivinhamos do próprio mosteiro de Liébana e de Beato ao conceber o Comentário arquetípico.

as exigências de um novo estilo - Maria Adelaide MIRANDA, "A iluminura românica em Portugal”, in A iluminura em Portugal. Identidade e Influências [...], p. 139.

${ }^{137}$ Por segunda fase de influência cultural francesa -proposta por José Mattoso entre 11301180 - entendemos, no caso da iluminura, uma adaptação regional ao ideal religioso dos cónegos regrantes, tal como foi vivido em São Rufo de Avinhão, sendo marcado por uma imitação deliberada das formas artístico-literárias francesas. Sobre este assunto veja-se Maria Adelaide MIRANDA, “A iluminura românica em Portugal” [...], pp. 134 e 138.

138 Aires Augusto do NASCIMENTO, "O "scriptorium" medieval instituição matriz do livro, [...], p. 89 .

${ }^{139}$ Sobre este assunto, presenciamos a comunicação oral ministrada por Saúl Gomes, no âmbito do seminário "MSML: Percurso de um fundo monástico - do mosteiro de Lorvão ao Ciberespaço", no Arquivo da Universidade de Coimbra, a 31 de Março de 2011, cujo assunto fulcral consistia na procura da aproximação de eventuais redes entre scriptoria e centros de irradiação livresca, por meio da análise de fragmentos de manuscritos medievais e modernos utilizados durante os processos de restauro dos fólios dos códices medievos do scriptorium de Lorvão, concluindo, porém, que nem mesmo esta análise se revela, suficientemente, coesa para sustentar eventuais atribuições.

${ }^{140}$ José Manuel RUIZ ASENCIO, pp. 198-199.

${ }^{141}$ Jorge da Silva Rocha referiu: «La Sainte-Croix de Coimbra et Sainte-Marie d Alcobaça représentent lamutation sous l'impulsion de l'exterieur tandis que Lorvão représente le dialogue et la cohabitation entre le monde latin, arab et l'Europe centrale.» - Jorge da Silva ROCHA, p. 81 . 
Ana de Oliveira DiAs, Commentarium in Apocalypsin: o número e a forma geométrica na tradição simbólica das ilustrações do «Beato» de São Mamede de Lorvão

Esta circulação promoveu, desta forma, a geração de uma troca de intensas influências, não somente do ponto de vista dos conteúdos literários e dos modelos iconográficos ${ }^{142}$, como também da criação ou transmissão do próprio imaginário característico destas regiões e comunidades, sendo a produção de carácter material o veículo transmissor, por excelência, destes aspectos culturais e espirituais.

Permanece ainda ignoto o modelo que terá constituído a base da cópia do «Beato» de Lorvão. A demorada e profunda análise levada a cabo por Peter Klein visou compreender as relações entre os modelos do stemma I (essencialmente os modelos $[\mathbf{C}],[\mathbf{E}]$ e $[\mathbf{O}]$ ), na busca de um hipotético protótipo para o «Beato» laurbanense. Klein concluíu, porém, que o exemplar de Lorvão será um dos manuscritos mais próximos da tradição original dadas as suas características pré-românicas, sendo provavelmente cópia de um Comentário de século $X$, hoje perdido, de meio moçárabe ${ }^{143}$, certamente mais próximo do original de Beato do que os supracitados exemplares do seu sub-ramo. Posto isto, resta-nos alinhar com as perspectivas e conclusões deste autor, e propor como hipotético modelo seguido o próprio «Beato» de Mumadona Dias, doado em 959 ao mosteiro de Guimarães, casa religiosa que correspondia ao mesmo orago e observância do mosteiro de Lorvão: São Mamede. ${ }^{144}$

Podemos ainda adivinhar, tanto pela geografia dos «Beatos» como pelas vicissitudes políticas deste contexto, que a Península terá possuído múltiplas cópias desta obra em circulação, tal como se verificou com outras obras relevantes nesta cronologia. ${ }^{145} \mathrm{E}^{\prime}$ igualmente notório que a literatura apocalíptica constituiu um género de culto sem precedentes nesta região, facto este possivelmente fundamentado por séculos de depredações muçulmanas, ou pela

\footnotetext{
${ }^{142}$ Sobre os «Beatos» e a circulação de influências, Aires Augusto do Nascimento referiu: «O testemunho mais antigo encontra-se no fragmento do Beato de Silos (Bib. Mon., frag 4), possivelmente ainda anterior ao século $\mathrm{X}$. Os outros testemunhos que vão do século $\mathrm{X}$ ao século XIII deixam entrever tanto a autonomia de uma região como as suas relações com outras regiões vizinhas.», Aires Augusto do NASCIMENTO, "A iluminura hispânica primitiva fragmentos de um universo cultural" [...], p. 115.

${ }^{143}$ A cópia de Burgos Osma, um dos exemplares mais antigos que conhecemos apresenta uma tipologia de emolduramentos semelhante às de Lorvão, constituindo este facto também um indício da antiguidade do modelo da cópia [L], John WILLIAMS, "The Illustrated Commentary" [...], p. 53.

${ }^{144}$ IDEM, ibidem, p. 42.

${ }^{145}$ Exemplo anterior do fenómeno de circulação de códices, visando as suas reproduções, foi o caso da famosa Crónica Moçárabe de 754, que viajou para Norte pela mão de moçárabes, sendo copiada na região da Galiza por volta de 800 e, seguidamente, em Oviedo, Rioja, Burgos, Saragoça e Pamplona. Também foi conhecida uma cópia na região de Évora-Beja - Aires Augusto do NASCIMENTO, "O «scriptorium» medieval, instituição matriz do livro [...], p. 89. Ainda sobre a circulação de códices na Península Ibérica veja-se Augusto do NASCIMENTO, "A iluminura hispânica primitiva [...], pp. 113 e 118; Manuel C. DÍAZ Y DÍAZ , Códices visigóticos en la monarquía leonesa, Léon, Centro de Estudios e Investigación «San Isidoro», 1983.
} 
instabilidade política e espiritual sentida - factores estes que poderão ter estado na base da actualidade desta obra, até ao século XIII.

Tal como referido anteriormente neste estudo, o temível avanço almóada em território portugalense foi um evento contemporâneo à produção deste códice laurbanense, podendo assim justificar acentuadas preocupações escatológicas; esta ofensiva poderá ter sido encarada como a verdadeira corporalização dos desígnios descritos na Revelação de João, e como um vaticínio do término da primeira Idade terrena, aos olhos desta comunidade. Assim, dado o desconhecimento das reais motivações para a concepção desta obra, mas considerando a sua data de elaboração e as contingências políticas, sociais e espirituais que temos notícia para a época, será mais plausível interpretar a sua replicação como uma resposta face à ameaça — tanto intrínseca como extrínseca - representada pela facção reformista e unificadora da Igreja, sentida através da Sé de Coimbra ${ }^{146}$, não ignorando porém, o peso das irrupções muçulmanas, mesmo num período de maior controlo e avanço na «Reconquista».

O Apocalipse poderá ter sido então encarado como uma parábola do fim dos tempos, e o seu Comentário como o "manual" para o exercício e para a vigília do fim dos tempos que, mais do que um cálculo numérico ou premonição, parecia apresentar-se como uma evidência real e crescente.

\section{A simbólica do número e da forma geométrica no «Beato» de Lorvão: relevância aritmológica e mensagem espiritual}

\subsection{A "Ciência numérica»: das correntes da Antiguidade à exegese medieval}

Objectos incessantes de estudo e devoção já desde a Antiguidade, o número e a forma geométrica foram alvos de profunda consideração, e de constante analogia simbólica, tendo sido cultivados não somente como elementos quantitativos, mas como agentes qualitativos, arquétipos ou conceitos auxiliares para a compreensão da realidade física e metafísica.

Diversos foram também os teólogos, ou Padres da Igreja grega e latina, que reconheceram a importância da análise e entendimento da «mística do número» ${ }^{147}$, tendo atentado sobre os múltiplos contextos — seja o cosmológico, o histórico, o cronológico, litúrgico ou escatológico ${ }^{148}$ - em que esta se manifesta nas Sagradas Escrituras. A passagem bíblica «Deus é medida, número e peso» ${ }^{149}$

\footnotetext{
146 Aires Augusto do NASCIMENTO, "Mosteiro de Lorvão: A História possível dos seus tempos antigos [...], Maria João BRANCO.

${ }^{147}$ Leslie FREEMAN, p. 45.

${ }^{148}$ IDEM, ibidem, p.45.

149 Formulação que podemos encontrar no Livro da Sabedoria: Sb 11.20. Também São Bernardo de Claraval nas suas meditações em torno da condição divina referiu, em $D e$ Consideratione, que Deus é «comprimento, largura, altura e profundidade», corroborando as considerações do Livro da Sabedoria, numa equação ainda mais precisa que evoca a base da estruturação e as qualidades inerentes a uma das principais corporalizações divinas: a catedral.
} 
Ana de Oliveira DiAs, Commentarium in Apocalypsin: o número e a forma geométrica na tradição simbólica das ilustrações do «Beato» de São Mamede de Lorvão

foi, deste modo, a primeira premissa que conduziu à valorização e interpretação do número, como conceito operativo, no seio da Cristandade. Deus foi tomado como a magna proporção, a medida e a harmonia por detrás de todas as coisas, e como demiurgo de toda a beleza corpórea.

Foi, no entando, a corrente Pitagórica ${ }^{150}$, e consequentemente as concepções platónicas $^{151}$ e neoplatónicas, que constituíram as filosofias precursoras e basilares para o desenvolvimento do pensamento numerológico medieval, que as assimilou essencialmente através da obra e das considerações de Agostinho de Hipona. ${ }^{152}$ Este foi inquestionavelmente um dos genitores da simbólica numérica na Igreja Latina ${ }^{153}$, ao encarar a necessidade de uma análise dos seus sentidos qualitativos nas Escrituras, na perspectiva do encontro da chave para a Revelação. ${ }^{154}$ Seguindo os princípios dos seus antecessores, reforçou, assim, a

${ }^{150}$ Por pitagóricos ou pitagorismo entendemos a escola ou grupo de seguidores do pensamento filosófico- matemático desenvolvido pelo filósofo grego Pitágoras de Samos no século V a.C. De acordo com a tradição, (da qual pouco conhecemos para além dos registos escritos dos seus seguidores, como Parménides, Filolau ou Platão) o pitagorismo desenvolveu-se em duas escolas distintas: uma primeira de base matemática que visava o aprofundamento dos estudos científicos-racionais e uma segunda vertente assente, essencialmente, sobre os aspectos mais espirituais e ritualísticos, sensíveis às virtudes do número na sua qualidade de organizador cósmico. O conhecimento era transmitido secretamente e por via exclusivamente oral, coexistindo ambas as escolas como espécie de «confraria», cujo juramento de fraternidade se fundava sobre os princípios da Tetráctris (que contempla a base de todo o conhecimento), enaltecendo a figura de Pitágoras como o transmissor desse princípio. Num sentido lato, os pitagóricos advogaram primordialmente a ideia da transmigração da alma e do modo como o domínio dos números constitui e determina a verdadeira natureza de toda a existência. Apesar de não podermos afirmar, cabalmente, qual a totalidade de ideias que estiveram no âmago do pensamento pitagórico (dado o carácter, verdadeiramente, disperso e insuficiente de informação de que dispomos), conhecemos grande parte da sua doutrina por meio de correntes que se desenvolveram a posteriori sobre estas bases, como o platonismo e o neoplatonismo. A obra Metafisica de Aristóteles constituiu, igualmente, uma das fontes que mais nos elucida em torno da filosofia e princípios pitagóricos. Sobre este assunto veja-se Matila GHYKA, Le nombre d'or: rites et rythmes pythagoriciens dans le développement de la civilisation occidentale, Paris, Gallimard, 2000.

${ }^{151}$ Platão, filósofo ateniense que, seguindo a tradição matemática pitagórica, foi considerado um dos precursores da simbólica numérica. Esta nomeação deve-se essencialmente ao Timeu, obra redigida em cerca de 360 a.C., na qual se debruça sobre a natureza do mundo físico e etéreo, sobre os propósitos e propriedades do universo, teorizando acerca do número, da proporção áurea, como elementos chave da Criação. Esta foi considerada uma obra de extrema importância no período medieval, constituindo a base do neoplatonismo, sendo alvo de estudos e comentários, particularmente, no século XII, por parte dos teólogos da Escola de Chartres, como Thierry de Chartres - Jean-Pierre BRACH, p. 16.

${ }^{152}$ Peter Brown, Augustin of Hippo - a biography, Berkeley, University of California Press, 2000 .

${ }^{153}$ Jean-Pierre BRACH, p. 46.

${ }^{154}$ Em De Libero Arbitrio, 1, XI, Santo Agostinho demonstrou esse carácter fundamental, omnipresente do número no universo: Intuere caelum et terram et mare et quaecumque in eis vel desuper fulgent, vel deorsum repunt vel volant vel natant; formas habent, quia numeros habent: adime illis haec, nihil erunt, AGOSTINHO DE HIPONA, Obras filosóficas, tomo III, 
Ana de Oliveira DiAs, Commentarium in Apocalypsin: o número e a forma geométrica na tradição simbólica das ilustrações do «Beato» de São Mamede de Lorvão

«ideia ternária» da geração divina, numa fórmula de maior apuro e rigor. Deus passou então a ser entendido como medida, cálculo e peso, ou seja, como o reflexo dos três passos da Criação: modus, species et ordo. Santo Agostinho restabeleceu, de igual modo, um sentido para os principais números bíblicos, atentando, com particular minúcia, sobre os dez primeiros. Sugeriu assim que entre a unidade («demiurgo numérico», do qual todos os restantes algarismos descendem) e a dezena estaria contido o simbolismo do conhecimento e ordenação do universo. Baseava-se assim no princípio pitagórico da Tetráctis ${ }^{155}$ (ou quaternário), cuja progressão aritmética $(1+2+3+4)$ tem como produto o número dez: essa totalidade universal. Devemos salientar que o bispo africano incidiu, do mesmo modo, sobre números que superam este valor (mas que com ele se relacionam) na sua demanda pela interpretação dos sentidos ocultos dos textos sagrados. ${ }^{156}$ É em obras como De Civitate Dei, De Libero Arbitrio ou De quantitate animae que nos são dadas a conhecer diversas das suas considerações aritmológicas sendo, porém, francamente dispersas as suas reflexões deste natureza.

Seguidor fiel da especulação numérica do bispo de Hipona (assim como de outros teólogos predecessores, como Cassiodoro ou Gregório Magno), Isidoro de Sevilha ${ }^{157}$ - personalidade fundamental no seio da tradição espiritual hispânica- dedicou igualmente os seus exercícios exegéticos a esta «ciência». Apesar de na realidade evidenciar um carácter mais compilativo do que interpretativo, o bispo hispalense primou por inaugurar um conjunto coerente e compacto de escritos subordinados a este tema. Referimo-nos pois a Liber Numerorum $^{158}$ (a este atribuído) e às Etymologiae III como fontes de maior

Madrid, Biblioteca de autores cristianos, 1947, p. 380. «Contempla o céu, a terra e o mar e todos quando nele existem e os astros que brilham no firmamento, os animais que caminham pela terra, as aves que voam pelo ar e os peixes que nadam no mar e verás que tudo tem a sua beleza, porque tem os seus números.» (tradução nossa).

${ }^{155}$ Por Tetráctis ou quaternário entendemos a série dos quatro primeiros números, cuja soma perfaz a dezena: $1+2+3+4=10$. De acordo com o entendimento simbólico pitagórico - que inaugurou este princípio- a Tetráctis reveste-se de um carácter sagrado, encerrando em si a chave do conhecimento universal (terrestre e divino) e a fonte da natureza eterna. Este princípio ganhou corpo, formando um triângulo cujos lados possuem quatro números, sendo o topo constituído pela unidade e a base pelo número quatro. Foi, igualmente, sobre esta fórmula que se fundou o juramento pitagórico, cujos discípulos prometiam honrar os ensinamentos de Pitágoras e a sua explicação da realidade por meio desta equação. Em termos musicais, significa o conjunto de notas perfeitas (acorde), a harmonia. Sobre este assunto veja-se Matila GHYKA.

${ }^{156}$ Não se deve pois, desprezar a teoria dos números de que as Sagradas Escrituras, em muitas passagens, desvendam o alto valor aos que as estudam com atenção, veja-se AGOSTINO DE HIPONA, A Cidade de Deus, vol. II, Lisboa, Fundação Calouste Gulbenkian, 1993, p. 1064.

${ }^{157}$ Sobre este teólogo veja-se Jacques FONTAINE, Isidore de Séville: genèse et originalité de la culture hispanique au temps des Wisigoths, Turnhoult, Brepols, 2000.

${ }^{158}$ Apesar da usual dificuldade de datação dos tratados de Isidoro de Sevilha, estima-se que o Liber Numerorum terá sido redigido entre os anos 612- 615. O tratado consiste numa análise dos sentidos simbólicos dos números bíblicos, analisados individualmente, desde a unidade ao número sessenta, visando explorar os princípios da estruturação cósmica por meio do algarismo. A sua originalidade reside, essencialmente, na sua forma (não tanto no conteúdo), primando, 
Ana de Oliveira DiAs, Commentarium in Apocalypsin: o número e a forma geométrica na tradição simbólica das ilustrações do «Beato» de São Mamede de Lorvão

relevância. A primeira obra, dedicada aos números nas Sagradas Escrituras, constitui uma das fontes de maior importância (apesar da sua discrição à luz da historiografia actual) para o estudo e entendimento da analogia numérica medieval, sendo o primeiro tratado verdadeiramente coerente e sistemático de numerologia cristã ${ }^{159}$, que possivelmente (apesar de desconhecermos o seu verdadeiro grau de difusão) terá influenciado todo o entendimento e experiência espiritual na Alta Idade Média hispânica. ${ }^{160}$ Por seu lado, as Etymologiae III constituem muito mais um compêndio matemático - a nível do cálculo, da geometria, da música e da astronomia - do que uma profunda análise hermenêutica. Contudo, no ponto intitulado Quid praestent numeri, Isidoro de Sevilha sintetiza a importância e finalidade - prática, moral e mística - do número na tradição cristã, referindo:

\begin{abstract}
Ratio numerorum contemnenda non est. In multis enim sanctarum scripturarum locis quantum mysterium habent elucet. (...) Omnia in mensura et numero et pondere fecisti. Senarius namque [numerus] qui partibus suis perfectus est, perfectionem mundi quadram numeri [sui] significatione declarat. Similiter et quadranginta dies, quibus Moyses et Helias et ipse Dominus ieiunaverunt, sine numerorum cognitione non intelleguntur. Sic et alii in scripturis sacris numeri existunt, quorum figuras nonnisi noti huius artis scientia solvere possunt. (...) Per numerum siquidem ne confundamur instruimur. Tolle numerorum in rebus omnibus, et omnia pereunt. Adime saeculo conptum, et cuncta ignorantia caeca conplectitur, nec differri potest a caeteris animalibus, qui calculi nesciunt rationem. ${ }^{161}$
\end{abstract}

contudo, pela coroação da longa tradição desta ciência - ISIDORO HISPALENSIS, Liber Numerorum, Paris, Les Belles Lettres, 2006, p. XXV. Afirmando-se como a maior compilação de noções aritmológicas da Alta Idade Média Liber Numerorum constituiu, assim, um precioso auxiliar para a compreensão desta ciência e para a sua acomodação à nossa metodologia de análise.

${ }^{159}$ ISIDORO HISPALENSIS, Liber Numerorum [...], p. XXIV.

${ }^{160}$ Saliente-se que, de acordo com o inventário dos testemunhos de códices visigóticos levado a cabo por Díaz y Díaz, entre os textos não litúrgicos são as obras de Isidoro de Sevilha que encontram maior expressão e se manifestam em maior número, José MATTOSO, "O imaginário da iluminura medieval" [...], p. 113.

${ }^{161}$ ISIDORO HISPALENSIS, Etimologías, vol. I, Madrid, Biblioteca de Autores Cristianos, 1993, pp. 424 e 426. «Não se deve menosprezar a ciência dos números. Em muitas passagens das Sagradas Escrituras é enfatizado o quão profundo é o mistério que os envolve. (...) Tudo foi criado com medida, número e peso. Assim, o número seis, que é perfeito nas suas partes, põe em evidência a perfeição do mundo. Do mesmo modo que, sem o conhecimento dos números não se pode compreender os quarenta dias que Moisés, Elias e Nosso Senhor jejuaram. Surgem também, nas Sagradas Escrituras, outros números cujo sentido não podem entender, se não os que conhecem a ciência desta arte. (...) Graças ao número aprendemos a não ser enganados. Suprime o número em todas as coisas e tudo se extingue. Retira ao tempo o seu cômputo e todo ficará envolto na cega ignorância: o homem não poderia diferenciar-se dos restantes animais, que ignoram a noção do cálculo.». 
Ana de Oliveira DiAs, Commentarium in Apocalypsin: o número e a forma geométrica na tradição simbólica das ilustrações do «Beato» de São Mamede de Lorvão

Torna-se, deste modo, evidente a real dimensão que o número assumiu nas estruturas mentais da alta Idade Média, tendo sido encarado como o principal diferenciador cognitivo entre o ser humano e às restantes espécies, tal como elemento capacitador que, por um lado desvia e previne o erro, e por outro instrui o homem nos «mistérios» eternos.

Subordinada e dependente desta «ciência», a geometria —est disciplina magnitudinis et formarum ${ }^{162}$ - abarca, segundo Santo Agostinho ${ }^{163}$, as mesmas exigências espirituais do número. ${ }^{164}$ Seguindo um princípio análogo, a «ciência das formas» ganha uma dimensão metafísica e surge como auxiliar e suporte para reflexão em torno das qualidades divinas e universais. ${ }^{165}$

As presentes considerações surgem assim como forte indício da relevância que ambos os elementos assumiram na visão e no imaginário medievo, que os encarou como elementos primordiais caracterizadores do mundo espiritual e do mundo revelado. Não nos surpreende, portanto, que Beato de Liébana tenha partilhado desta tradição aquando da elaboração do seu Comentário ${ }^{166}$. Através do estudo de Leslie G. Freeman ${ }^{167}$, foi assim possível compreender que o monge asturiano integrou efectivamente considerações numerologicas na estrutura interna e externa da sua obra ${ }^{168}$, tendo-se inspirado, decerto, nos símbolos que the foram legados pela tradição bíblica, pela Patrística, pela literatura eclesiástica e pelos autores clássicos que incorporavam as crenças e as práticas religiosas do seu tempo. ${ }^{169}$ Compreendemos então que a «ciência aritmética» foi para Beato

${ }^{162}$ ISIDORO HISPALENSIS, Etimologías [...], p. 422. «É a ciência da medida e das formas» (tradução nossa).

${ }^{163}$ Na sua obra De quantitate animae, Santo Agostinho dedica diversos capítulos à meditação em torno das formas geométricas e da sua perfeição e, numa estrutura de diálogo, reflecte em torno da sua formação, evidenciando discretas analogias e meditações ontológicas.

${ }^{164}$ Jean-Pierre BRACH, p. 50.

165 Jacques THOMAS, La Divine Proportion - mesure, nombre et poids - études de symbolique chrétienne, Paris, Archè edidit, 1993, p. 74.

${ }^{166}$ No Livro IV do Comentário ao Apocalipse, também Beato citou esta mesma passagem de Isidoro de Sevilha, autor que o monge de Liébana tomou como fonte e paradigma para a sua obra. A presente citação comprova, assim, a importância e destaque que o número assumiu para Beato e como este autor se revela herdeiro da tradição simbólica advogada pelo bispo sevilhano.

${ }^{167}$ Leslie FREEMAN, "Elementos simbólicos en la obra de Beato", in Beato de Liébana: Obras completas y complementarias (ed. de Juan ECHEGARAY, et. al), Madrid, Biblioteca de Autores Cristianos, 2004, pp. 33-56.

168 Como analisou Leslie Freeman, o Comentário ao Apocalipse de Beato encontra-se estruturado de um modo bastante específico, sendo este facto o elemento que considera ser o ponto máximo de originalidade do monge de Liébana ao conceber a sua obra. A estrutura interna do Comentário denota evidentes preocupações numerológicas e uma trama matemática premeditada. Salientamos o facto deste se organizar num conjunto de doze livros que apresentam ciclos de divisões de sete momentos: seis pontos para explicação dos temas e o sétimo para recapitulação, numa possível analogia $(6+1=7)$ aos seis dias da criação e ao sétimo término-transacional. Sobre este assunto veja-se Leslie FREEMAN, pp. 43-50.

${ }^{169}$ IDEM, ibidem, p.33. 
Ana de Oliveira DiAs, Commentarium in Apocalypsin: o número e a forma geométrica na tradição simbólica das ilustrações do «Beato» de São Mamede de Lorvão

um importante suporte para o treino da hermenêutica, e uma via para compreender o divino. ${ }^{170}$ Através desta revigorou a sua mensagem, dotando a sua obra de uma componente reflexiva e meditativa profunda, e inaugurando uma via interpretativa para os seus leitores despertos e iniciados nesta "arte». ${ }^{171}$ Segundo Freeman, o método de Beato consistiu na colocação de números em relação entre si nas suas obras, de forma a obter correspondências e equivalências harmoniosas e paradigmáticas, evocando o sentido das Escrituras. Perspectivou também, certamente, a apreensão mais profunda do texto, e através disso, a preparaçãoo para a vigília do fim dos tempos. Sabemos assim que, também este autor, à semelhança dos seus antecessores, considerou o número, o cálculo, e necessariamente a geometria, a chave para a compreensão de Deus ${ }^{172}$. Deste modo, a aproximação e a sublimação da harmonia e das verdades divinas foi diversas vezes explorada através da reprodução desses arquétipos num plano material. Apesar desta ser uma questão verdadeiramente complexa e de grande dificuldade, podemos compreender este conceito —e esta prática presente no imaginário medievo - através das palavras de Agostinho de Hipona, que descreve a analogia entre o divino e o humano, e a forma como este último também opera de acordo com esses números superiores e cria as suas obras materiais:

et omnium quidem formarum corporearum artifices homines in arte habent numeros, quibus coaptant opera sua: et tamdiu manus atque instrumenta in fabricando movent, donec illud quod formartur foris, ad eam quae intus est lucem numerorum relatum, quantum potest impetret absolutionem, placeatque per interpretem sensum interno iudici supernos numeros intuenti. Quaere deinde artificis ipsius membra quis moveat; numerus erit: nam moventur etiam illa numerose. $^{173}$

\footnotetext{
${ }^{170}$ Ressalvamos o exemplo mais flagrante da importância que Beato de Liébana (e os seus contemporâneos) atribuíam ao número: os fólios da Sabedoria ou Nomes do Anticristo, que no códice de Lorvão correspondem aos fólios 167 e 167v. Estes constituem um grupo de anagramas onde se calcula os números correspondentes ao nome do Anticristo, questão associada à descrição presente em Ap 23, 1-5. Sobre este assunto veja-se Jorge da Silva ROCHA, pp. 460-468.

${ }^{171}$ Expressão utilizada por Isidoro de Sevilha para caracterizar a capacidade de entendimento do fenómeno numérico: Sic et alii in scripturis sacris numeri existunt, quorum figuras nonnisi noti huius artis scientia solvere possunt - ISIDORO HISPALENSIS, Etimologías [...], p. 426 (sublinhado nosso).

${ }^{172}$ Leslie Freeman, p. 47.

173 AGOSTINHO DE HIPONA, Obras filosóficas, tomo III, Madrid, Biblioteca de Autores Cristianos, 1947, p. 130 (De Libero Arbitrio). «Até mesmo os artífices de belezas corpóreas [objectos tangíveis], nas suas obras, fazem uso dos seus números, conforme os quais executam as suas obras e não cessam nem no seu empenho, nem no manejo dos seus instrumentos, até que a obra ganhe forma exterior, chegue a alcançar, se é possível, a perfeição desse exemplar ideal e obtenha, por meio dos sentidos exteriores, a aprovação do juiz interno, que tem sempre em vista os números superiores. Se procuras depois saber qual é o motor [força anímica] dos seus braços
} 
Ana de Oliveira DiAs, Commentarium in Apocalypsin: o número e a forma geométrica na tradição simbólica das ilustrações do «Beato» de São Mamede de Lorvão

Este aspecto poderá então ter constituído uma das metas quer da estrutura externa textual, como das ilustrações do Comentário ao Apocalipse de Beato de Liébana e das suas múltiplas cópias. ${ }^{174}$

\subsection{O número e a forma geométrica nas ilustrações do «Beato» de Lorvão}

Distinguindo-se pelo carácter verdadeiramente sui generis das suas iluminuras, a originalidade do Comentário de Lorvão reside na singularidade estilística e nas características formais incomuns ${ }^{175}$ que podemos apreciar no seu corpus ilustrativo. Para além dos aspectos supracitados, apresenta ainda particularidades iconográficas destacáveis, que influem, necessariamente, na leitura do programa pictórico desta cópia.

Como herdeiro fiel do imaginário do Livro do Apocalipse, foi então possível verificar acentuadas preocupações numerológicas na imagética deste manuscrito. Visando, assim, analisar estes domínios simbólicos e as suas relações iconográficas e conceptuais, procurámos identificar e compreender a manifestação dos elementos predominantes nas visões descritas por São João, como sejam: astros, agentes divinos, agentes maléficos, homens, animais, elementos arquitectónicos, e, através da categorização destes elementos e de uma abordagem quantitativa (incidindo sobre cada ilustração, individualmente), reconhecer eventuais padrões de ocorrência numérica relacionáveis com estes mesmos elementos. Este método contabilístico, juntamente com a consequente interpretação qualitativa dos dados adquiridos, permitiu-nos constatar que tanto o número, como a forma geométrica, têm um papel fundamental na economia da

[mãos, membros], verás que é o número, pois se movem [braços, mãos...] com cálculo [de forma matemática, precisa, para a criação das obras]».

${ }^{174}$ A título exemplificativo do carácter ritualístico das imagens do Comentário ao Apocalipse de Lorvão, destacamos um aspecto que se revela verdadeiramente curioso nesta cópia. Do ponto de vista da «mise-en-page» (concretamente dos emolduramentos das ilustrações), é verificável uma tendência particular para a criação de estruturas imperfeitas, exclusivamente, aquando da presença de personagens associadas ao mal, tal como podemos observar nos fls. 43, 171, 181v., 186v., 191, 200, 201, 203v. Estas características não são verificáveis em nenhuma outra situação e desta forma cremos que evidencia (indo ao encontro do que, preliminarmente, Jorge da Silva ROCHA, p. 114 e 715 referiu) uma clara opção do ilustrador de associar estruturas imperfeitas a agentes maléficos, resguardando o domínio da perfeição e ordem geométrica para as representações de agentes do bem. Mais do que um claro carácter simbólico latente, este manuscrito denota uma intenção ritualística, cujo conteúdo espiritual precede a forma e o exercício da ilustração constitui, igualmente, um exercício de devoção: atribuindo a imperfeição ao plano do caos e a perfeição ao plano da ordem, numa dinâmica de oposição e dualismo característico da literatura apocalíptica. Em nenhuma outra cópia se verifica, tão vincadamente, esta tendência, levando-nos a questionar se o copista e ilustrador do códice de Lorvão teria presente um modelo que apresentaria, de antemão, estas características, ou se terá constituído apanágio da cópia laurbanense.

${ }^{175}$ Referimo-nos pois a determinadas características da «mise-en-page», como a relação entre os emolduramentos e natureza dos agentes figurados (características apenas verificada no «Beato» de Lorvão e de Tábara), ou mesmo a cor destas iluminuras, tão invulgar no panorama dos Comentários hispânicos, dada a sua paleta, verdadeiramente, reduzida. Para uma compreensão mais profunda dos contextos -materiais, sociais e até simbólicos- de produção deste manuscrito, também este aspecto cumpre ser rigorosamente estudado. 
Ana de Oliveira DiAs, Commentarium in Apocalypsin: o número e a forma geométrica na tradição simbólica das ilustrações do «Beato» de São Mamede de Lorvão

obra laurbanense, encontrando-se estes ao serviço da transmissão das mensagens das próprias storiae, desempenhando um importante papel enquanto vectores das mensagens espirituais.

Deste modo, ao compararmos as restantes ilustrações da família I, IIa e IIb com as suas congéneres no exemplar $[\mathbf{L}]$, foi possível apurar com exactidão o grau de especificidade compositiva deste modelo de Lorvão (modelo de Lorvão ou cânone ilustrativo particular: M.L.). Notamos que em $31 \%$ dos casos (correspondente a vinte e duas iluminuras) este apresenta soluções iconográficas divergentes ao paradigma seguido pelas restantes cópias sobreviventes (modelo dos «Beatos» ou cânone ilustrativo geral - M.B.), permitindo desde logo entender que, devido ao considerável grau de especificidade do manuscrito de Lorvão, também o seu discurso simbólico se preenche de singularidades.

\section{Modelos de representação no Beato de Lorvão}

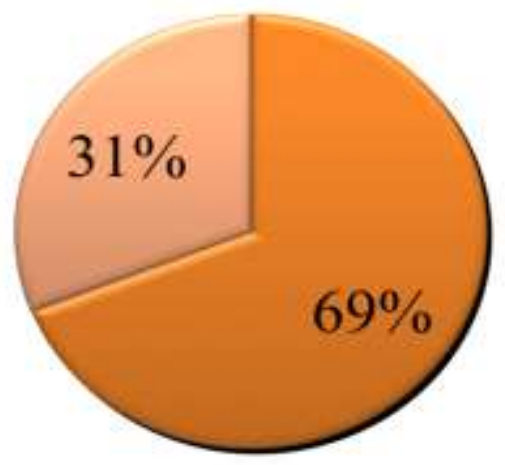

M.B

M.L

Fig.1. Gráfico circular referente aos paradigmas de ilustração seguidos no Comentário ao Apocalipse do Mosteiro de Lorvão.

O grau de originalidade desta cópia é algo que, no entanto, não podemos analisar de forma rigorosa, visto não possuirmos qualquer indício de qual terá constituído a sua fonte, ou qual o critério de reprodução adoptado neste mosteiro. Cremos, contudo, que estes particularismos se devem ao modelo seguido pelo ilustrador que decerto apresentaria a grande maioria das características hoje reconhecíveis na cópia laurbanense. A possibilidade de o arquétipo se tratar de um exemplar da primeira metade do século X transforma, então, este códice numa «janela» ou ponte para a estética e imaginário da Alta Idade Média hispânica, materializado neste ímpar exemplar tardio na tradição dos «Beatos».

\subsubsection{O número: análise quantitativa}

$\mathrm{O}$ estudo rigoroso das iluminuras em causa permitiu-nos compreender a dupla natureza da manifestação numérica no Comentário de Lorvão. Notamos assim que estas imagens vão para além da função de ilustração do conteúdo textual ou seja, da representação dos números já de si referidos no texto do Apocalipse ou no Comentário de Beato - demonstrando, em diversas ocasiões, autonomia e descomprometimento em tanto relação ao cânone ilustrativo geral, como às fontes textuais. São precisamente essas particularidades figurativas, específicas 
do manuscrito de Lorvão, que sublinham o peso e relevância que o número, como elemento simbólico, adquiriu na presente cópia. Estas características devem-se possivelmente ao conteúdo de um modelo anterior, que não chegou aos nossos dias, ou mesmo, quiçá, a directrizes superiores do scriptorium ${ }^{176}$, que poderão ter conduzindo o ilustrador na composição do programa iconológico deste códice.

Desta forma, e para um entendimento mais concreto desta questão, tivemos em consideração os padrões numéricos que se evidenciam, não somente nas ilustrações das storiae, como também na estruturação, planificação e emolduramentos destas ilustrações. Em suma, a manifestação do número foi analisada no seu sentido mais lato, visando perscrutar a carga e importância que este deteve na concepção do programa iconográfico, e no pensamento simbólico reflectido nesta cópia. Cumpre referir que, de um universo de setenta e uma imagens, baseámo-nos num total de cinquenta e seis para esta análise, como exemplos mais expressivos; salientamos ainda que a ilustração do mappa-mundi não foi contemplada no presente estudo dada a sua natureza fragmentária e, portanto, inconclusiva.

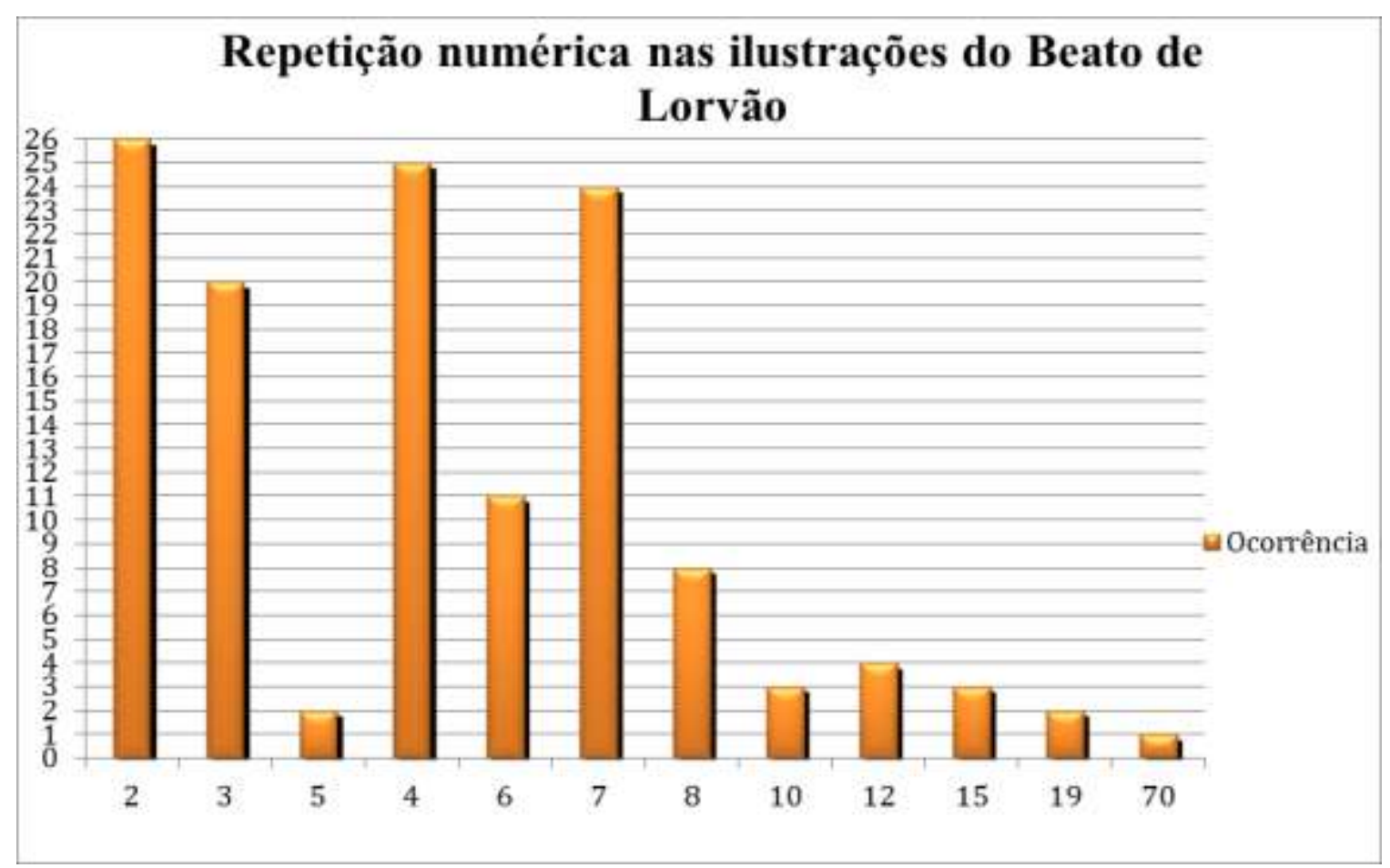

Fig. 2. Repetição numérica nas ilustrações do «Beato» de Lorvão

O presente gráfico, indicador da ocorrência numérica no códice laurbanense, revela a preponderância de um grupo de doze números no panorama geral, sendo

\footnotetext{
${ }^{176}$ No Concílio de Niceia, em 787, estabeleceu-se que a composição de imagens religiosas devia obedecer unicamente aos princípios da Igreja e tradição Patrística estabelecidos pela entidade encomendante, afastando qualquer rasgo de originalidade compositiva por parte do artífice executante - Jacques THOMAS, p.104.
} 
Ana de Oliveira DiAs, Commentarium in Apocalypsin: o número e a forma geométrica na tradição simbólica das ilustrações do «Beato» de São Mamede de Lorvão

estes: o número dois (26 ocorrências), o quatro (25), sete (24) e o três (20) como números predominantes; apresentando igualmente o seis (11), o oito (8), o doze (4), o dez e o quinze (3) um considerável grau de expressividade. Ressalvamos, porém, que números cinco, dezanove (2) e setenta (1), foram igualmente contabilizados e considerados neste estudo, dada a sua particular manifestação nesta cópia. Muito embora a unidade não se encontre representada graficamente na nossa sondagem (elemento que preferimos não incluir dado o seu carácter não numérico à luz dos estudos da Antiguidade), iremos brevemente aflorar o seu significado e as suas propriedades simbólicas gerais e particulares.

Consequentemente, comprova-se a hegemonia dos números até à dezena no presente estudo, fenómeno este por certo justificado pela importância simbólica a estes atribuída pela (e desde) filosofia pitagórica. Na perspectiva clássica, entre a unidade e a dezena -o elemento criador divino (1) e a potência universal (10) encontravam-se todos os restantes números gerados, sendo precisamente estes os que demonstram o mais elevado registo de ocorrências na totalidade neste manuscrito.

O diagrama que ora apresentamos demonstra em termos percentuais a mancha ocupada pelos números analisados no «Beato» português, transmitindo, de forma mais clara, a supremacia e frequência destes elementos.

\section{Percentagem de repetição numérica nas ilustrações do Beato de Lorvão}

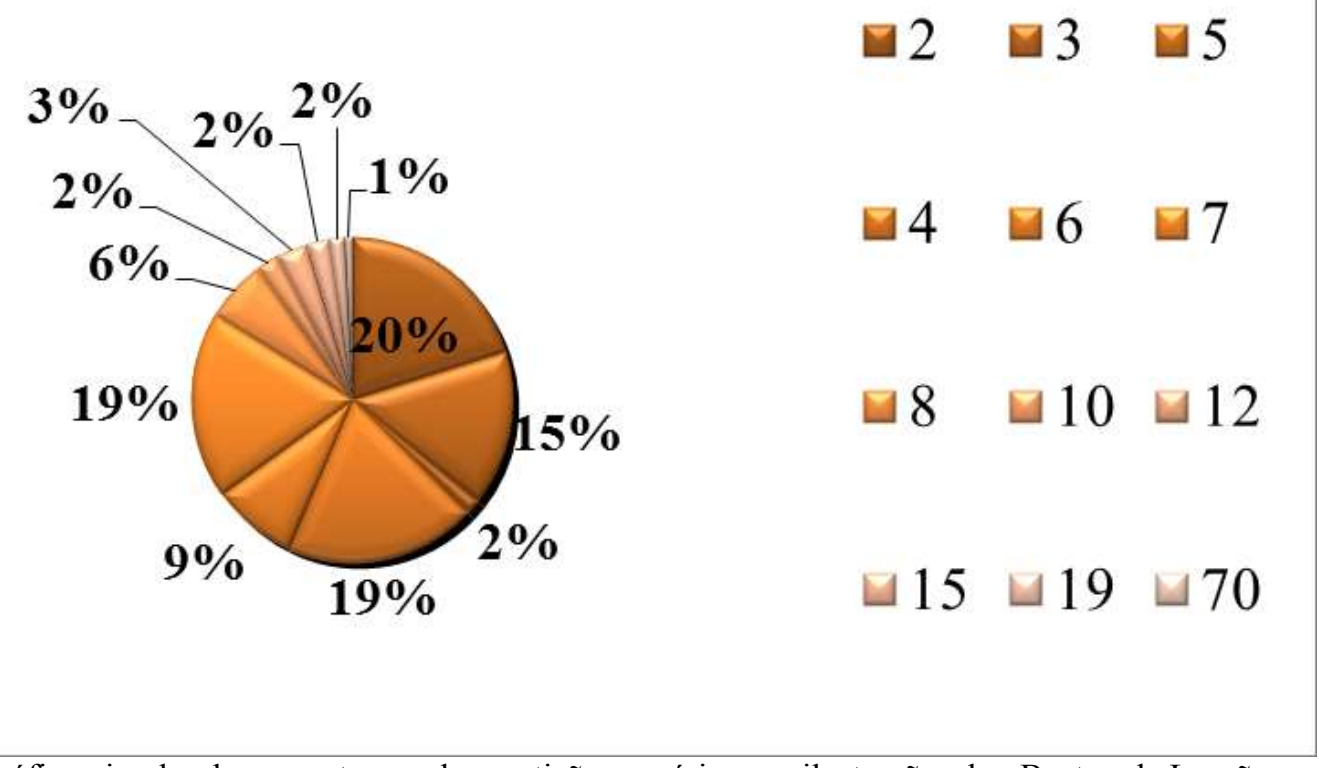

Fig. 3. Gráfico circular da percentagem de repetição numérica nas ilustrações do «Beato» de Lorvão

Deste modo, apoiados nas fontes e autores supracitados - dos quais Beato se considerou descendente e herdeiro - cumpre agora ser aflorada a natureza simbólica e a função destes números na obra. O significado peculiar de alguns deles (dos quais temos notícia desde a Antiguidade), permite-nos então 
Ana de Oliveira DiAs, Commentarium in Apocalypsin: o número e a forma geométrica na tradição simbólica das ilustrações do «Beato» de São Mamede de Lorvão

estabelecer analogias com as ilustrações deste Comentário, procurando assim um primeiro nível de interpretação destes elementos simbólicos no códice laurbanense.Todavia, como refere Leslie Freeman, os números constituem parte de um universo amplo e verdadeiramente complexo, detentor de diferentes graus de entendimento, muitos ainda indecifráveis aos olhos do historiador contemporâneo. Podem assim ser examinados sobre múltiplas perspectivas, tal como a sua relação com outros algarismos (como os números múltiplos e os primos), por decomposição nos seus factores, por condensação ${ }^{177}$, através da soma de todos os números desde a unidade ao número dado ${ }^{178}$, ou ainda por meio do cálculo e analogia com as formas geométricas. ${ }^{179}$ Sublinhamos que a nossa análise se prende, antes de mais, ao estudo dos números de maior relevância nesta cópia e ao modo como, nas suas primeiras instâncias, influem na concepção do programa iconográfico e iconológico do manuscrito [L]. Para isso, definimos como estratégia, a análise deste elemento no seu estado puro (número per se), por decomposição ${ }^{180}$ e na relação com as formas geométricas, visando desta forma entender a sua manifestação e expressividade nestas iluminuras.

\subsubsection{O número nas ilustrações do «Beato» de Lorvão: análise qualitativa}

\section{De Vnitate}

Muita embora não contemplada nos gráficos propostos, cabe à unidade a primeira de todas as considerações. Em termos filosófico-matemáticos nunca foi entendida como número no seu sentido quantitativo; foi antes tomada como o primeiro factor, originário de toda a realidade mensurável ${ }^{181}$, o princípio indivisível e indissolúvel, que como uma mónade compreende o início e o fim. Não nos é, portanto, estranho que mediante esta definição clássica, a metáfora entre a unidade e o ente divino tenha sido estabelecida em contexto cristão, tendo esta clara associação simbólica reclamado consequentemente o seu lugar na arte, visando reforçar iconograficamente essa comparação, e sublimar a unicidade de Deus.

\footnotetext{
${ }^{177}$ Por condensação entendemos a soma de todos os dígitos de um número de modo a obter um número da primeira dezena, exemplo: $572=5+7+2=14=1+4=5$.

178 À semelhança do princípio da Tetráctis: $4=1+2+3+4=10$, sendo quatro o número dado e dez o resultado da soma de todos os números anteriores a esse mesmo número pré-estabelecido.

${ }^{179}$ Leslie FREEMAN, p. 36.

180 A análise qualitativa por decomposição baseia-se na compreensão da formulação de determinados números por meio da soma, subtracção, divisão ou multiplicação dos seus constituintes. Com exemplo salientamos o número sete que surde da junção entre o número três e o quatro $(3+4=7)$, ou seja a ordem celeste (três) somada à terrestre (quatro) para originar a plenitude (sete).

${ }^{181}$ Numerus autem est multitude ex unitatibus constituta. Nam unum semen numeri esse, nom numerum. «O número é uma pluralidade constituída a partir de unidades, pois o uno não é um número, mas sim a origem do número.» (tradução nossa) - ISIDORO HISPALENSIS, Etimologías [...], p. 424.
} 
Ana de Oliveira DiAs, Commentarium in Apocalypsin: o número e a forma geométrica na tradição simbólica das ilustrações do «Beato» de São Mamede de Lorvão

Com efeito, não nos surpreende que nas iluminuras laurbanenses encontremos a unidade associada a representações de Deus, de Cristo ${ }^{182}$ e do Agnus Dei. Este facto ganha maior evidência nas composições pautadas por uma construção mais complexa ou variada, em que o destaque atribuído a estas entidades não se filia meramente nos seus atributos (como o nimbo com cruz inscrita, no caso de Cristo), mas no número que as define.
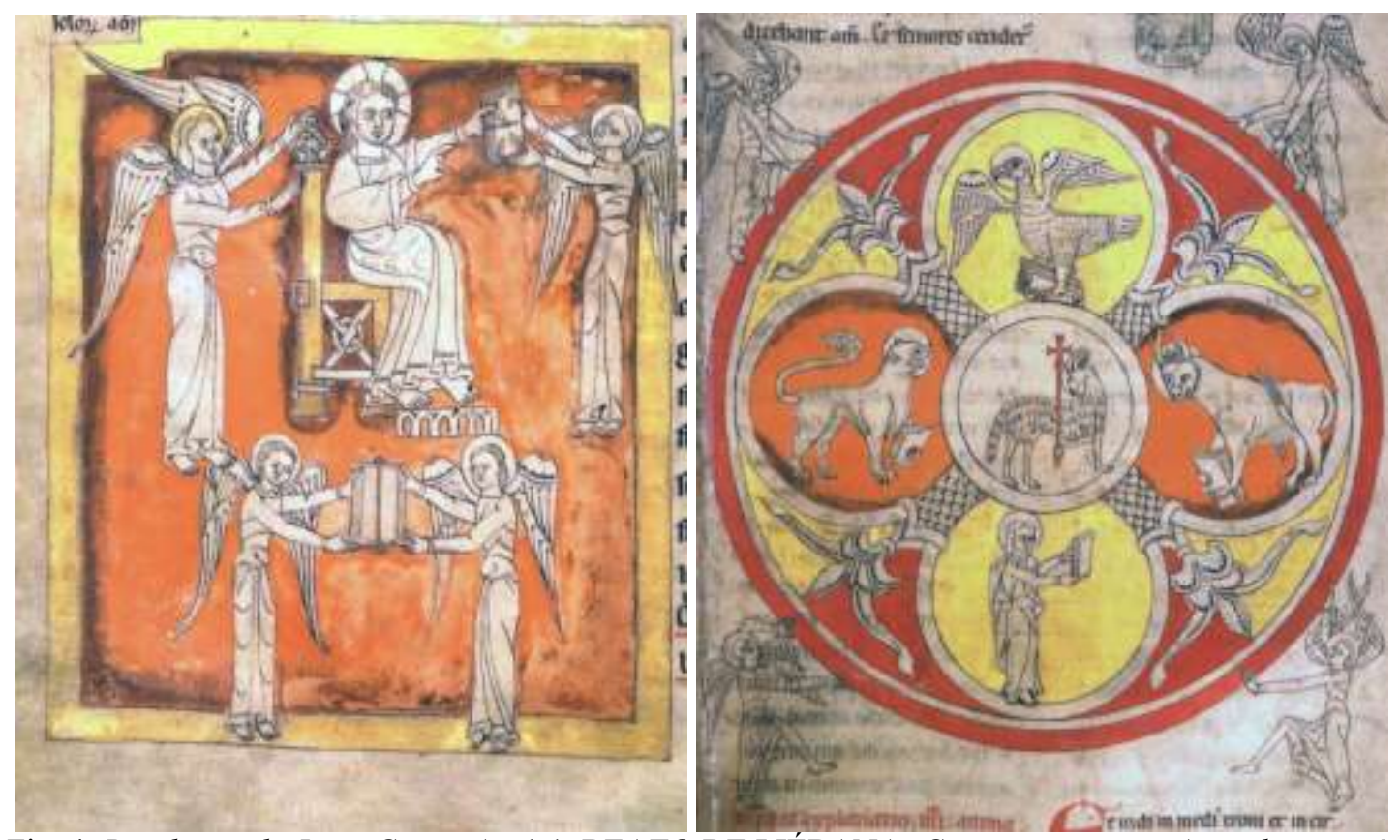

Fig. 4. Revelação de Jesus Cristo. Ap 1,1. BEATO DE LIÉBANA, Commentarium in Apocalypsin; cópia ilustrada do Mosteiro de S. Mamede de Lorvão. Imagem gentilmente cedida por DGLAB/ANTT, Ordem de Cister, Mosteiro de São Mamede de Lorvão, Livro 44 (C.F. 160), fl. 12v.

Fig. 5. visão do Cordeiro e dos quatro seres viventes. Ap. 5,6. BEATO DE LIÉBANA, Commentarium in Apocalypsin; cópia ilustrada do Mosteiro de São Mamede de Lorvão [...], fl. 90.

Ainda que bastante óbvia esta ideia, torna-se necessário referir que, ao contrário de outras personagens, como o próprio apóstolo João ${ }^{183}$, Deus ou Cristo não se encontram em vez alguma multiplicados, corroborando assim o seu carácter uno, perfeito e indivisível, que reforça um dos primeiros dogmas da Igreja. Os fólios $12 \mathrm{v}, 14 \mathrm{v}, 90,120,135,169,172 \mathrm{v}, 191,196 \mathrm{v}, 202 \mathrm{v}, 207,209 \mathrm{v}$, $210,217^{184}$, comprovam esta ideia, verificando-se uma constante procura da centralização e individualização destas personagens, colocadas em destaque pela sua figuração única, ímpar, desprovida de dualismos ou ambiguidades. Deus e

${ }^{182}$ Apesar de simbolicamente Cristo apresentar uma natureza dual - divina e humana - a sua figuração no Apocalipse de Lorvão pretende muito mais ressalvar as suas qualidades ímpares e posicioná-lo como força superior, única e verdadeira, por oposição aos agentes maléficos. Assim assume um estatuto uno, sendo caracterizado pelo número um, à semelhança do Pai.

${ }^{183}$ Exemplos de composições no Comentário de Lorvão que evidenciam o fenómeno de desdobramento de personagens - veja-se Anexo iconográfico, Fig. 41.

${ }^{184}$ Anexo iconográfico, Figs. 48, 49, 55, 56. 
Cristo determinam antes toda a multiplicidade, sendo perceptível a clara intenção de demarcar este importante pilar da fé na imagética do Comentário.
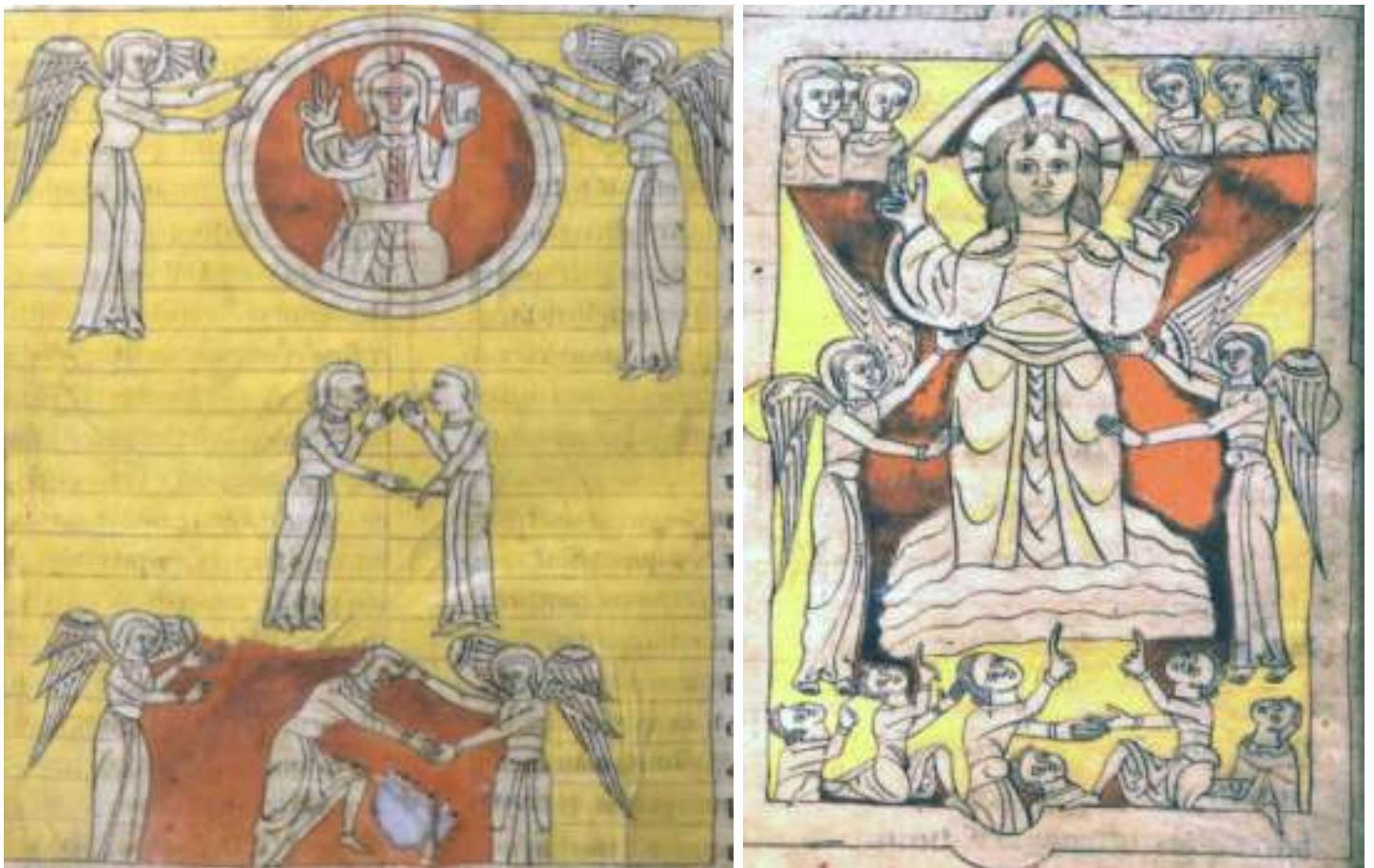

Fig. 6. A despedida de João. Ap. 22, 6-9. BEATO DE LIÉBANA, Commentarium in Apocalypsin; cópia ilustrada do Mosteiro de São Mamede de Lorvão [...], fl. 217.

Fig. 7. A segunda vinda de Jesus Cristo. Ap 1, 7-9. BEATO DE LIÉBANA, Commentarium in Apocalypsin; cópia ilustrada do Mosteiro de São Mamede de Lorvão [...], fl. 14v.

\section{De binario numero}

Liderando a sondagem das ocorrências no presente manuscrito, o número dois exalta o princípio do dualismo. Sendo divisível apenas por si próprio ou pela unidade, este foi considerado a primeira de todas as rupturas $\mathrm{e}$ desdobramentos. ${ }^{185}$ Foi, portanto, comum encontrar-se associado às principais questões dialécticas na arte medieva, como a formulação e figuração de opostos, antagonismos e polaridades características do domínio polimórfico dos símbolos. No entanto, ao verificarmos a expressão deste número no contexto das ilustrações do «Beato» laurbanense, compreendemos que este exalta (numa primeira instância) a natureza e as qualidades do par, prendendo-se maioritariamente à representação de seres celestes ou sacralizados - anjos e almas - como agentes das acções e desígnios divinos. ${ }^{186}$ Começamos por observar no fólio $14 \mathrm{v}-A$ segunda vinda de Jesus Cristo ${ }^{187}$ — dois anjos que

\footnotetext{
185 Jean CHEVALIER, Alain GHEERBRANT, "Dois", in Dicionário dos Símbolos - Mitos, sonhos, costumes, gestos, formas, figuras, cores, números, Lisboa, Teorema, 1982, pp. 270271, ref. p. 270.

${ }^{186}$ Sobre a qualificação dos pares veja-se ISIDORO HISPALENSIS, Liber Numerorum [...], p. 12.

${ }^{187}$ Cumpre sublinhar o precioso auxílio que a monografia de Anne de Egry (como exemplo da primeira obra dedicada exclusivamente a este «Beato»), constituiu para a identificação
} 
Ana de Oliveira DiAs, Commentarium in Apocalypsin: o número e a forma geométrica na tradição simbólica das ilustrações do «Beato» de São Mamede de Lorvão

acompanham e ladeiam Cristo, na sua aparição. Figurados num limbo entre o mundo celeste e terrestre, estes posicionam-se entre o Messias - apoiando-o e venerando-o em ambos os flancos - e, como dois fiéis da balança, sugerem um estado de equilíbrio. Também no fólio 135 - Os sete anjos trombeteiros ${ }^{188}$ observamos o mesmo tipo de representação: Cristo, sobre o altar, encontra-se ladeado por duas almas (ou anjos não alados) e, tal como na descrição do Livro da Revelação (Ap 8, 2-6), estas establecem figurativamente (e simbolicamente) esse mesmo equilíbrio dual. No fólio 143 - A sexta trombeta - a acção divina que comanda a libertação dos quatro anjos cativos é levada a cabo por um par de anjos: um exibe a trombeta, outro as Escrituras que predestinam o acontecimento, reforçando, uma vez mais, a ideia acima proposta em torno do par.

Vincadamente associadas a este princípio, as duas testemunhas - par eleito e sacrificado por Deus - substanciam igualmente o sentido simbólico deste número. Nos fólios 148v., 149 e 150v. surgem debuxadas nos diferentes momentos da sua acção - desde o massacre ao júbilo - demarcando o carácter que lhes é mais próprio: o número, como pluralização do acto criador.

Do mesmo modo, o fólio 150v. segue esta dinâmica. Sentados sobre dois tronos, observamos duas figuras nimbadas que ladeiam e suportam o busto de Cristo, tal como os anjos supracitados; seguindo a interpretação iconográfica de Jorge da Silva Rocha estes agentes antropomórficos (mas de género aparentemente masculino), personificam a Igreja $^{189}$, e o número que as caracteriza é precisamente o número dois, a formulação do par, o primeiro número gerado através da unidade. Por conseguinte, o mesmo tipo de representação é também verificado nos fólios 202v (As Almas dos mártires), $207^{190}$ (O Juizo Final), 210 ( A água e a árvore da vida), tal como no penúltimo fólio ilustrado deste códice (A despedida de João).

iconográfica das ilustrações discriminadas no presente estudo. Sublinhamos, porém, que terá sido na obra de Peter KLEIN, Beato de Liébana: la ilustración de los manuscritos de Beato y el Apocalipsis de Lorvão (trad. Beatriz MARIÑO), Valencia, Patrimonio Ediciones, 2004, na qual nos apoiámos mais firmemente para o efeito.

${ }^{188}$ Anexo iconográfico, Fig. 49.

${ }^{189}$ «Puis, plus avant, le commentateur mentionne: “Ils sont deux les édifices dans l’Église, l'un bâti sur un rocher qui est le Christ, l'autre sur le sable, qui est la confiance dans ce monde (Duo enim sunt aedificia, unum supra petram, quod est Christus, alterum supra arenam, quod est fiducia mundi huius). Les deux figures assises qui sont montés au ciel au moyen des deux Testaments sur les trônes représentent probablement ces deux édifices de l'Église ou ceux qui sont montés au ciel au moyen des deux Testaments. Ce sont là les seuls passages du commentaire qui peuvent être reliés à cette iconographie et l'expliquer".» - Jorge da Silva ROCHA, pp. 411 e 412.

${ }^{190}$ Anexo iconográfico, Fig. 56. 

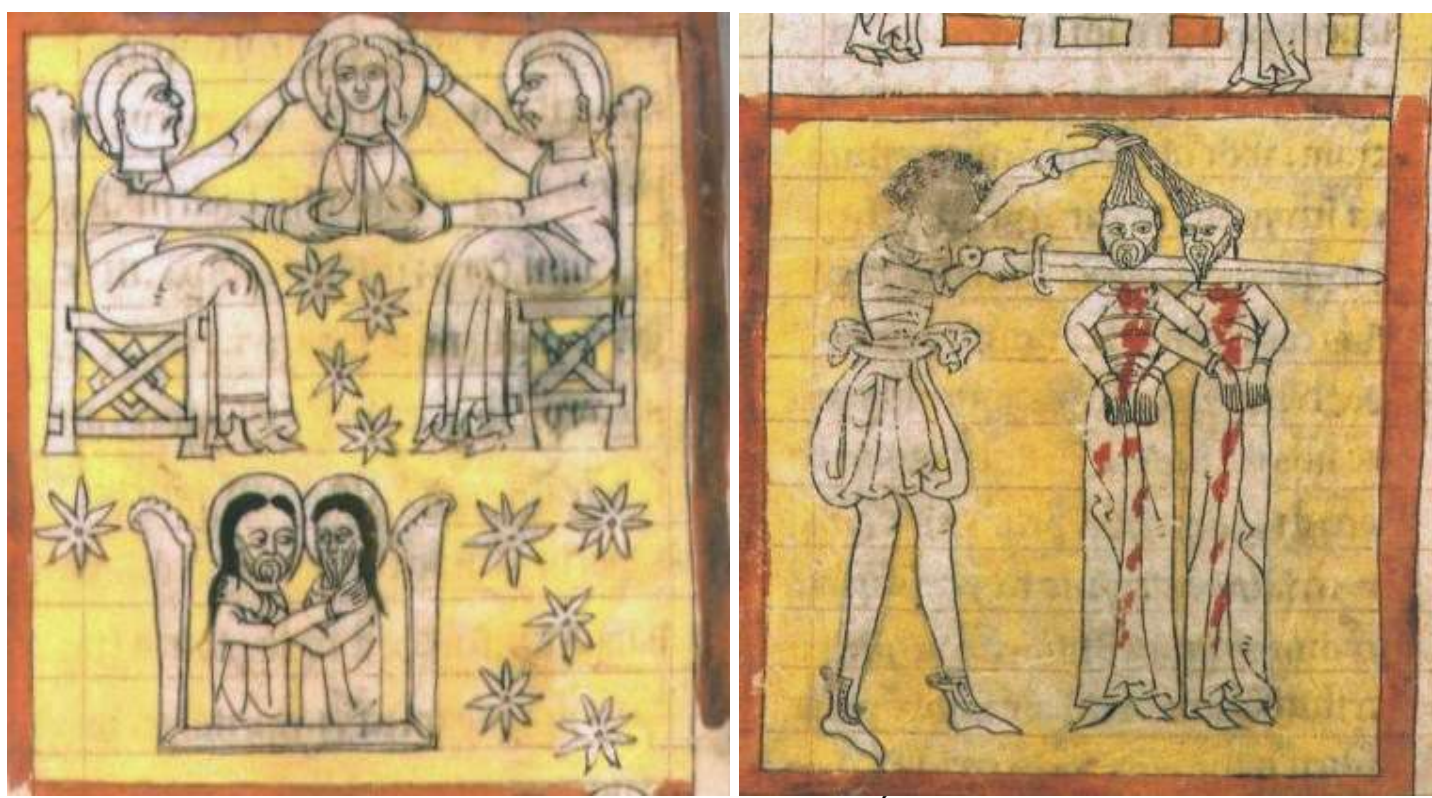

Fig. 8 e 9. As duas testemunhas (pormenor), BEATO DE LIÉBANA, Commentarium in Apocalypsin; cópia ilustrada do Mosteiro de São Mamede de Lorvão [...], fl. 149v.,150v.

Contudo, foi ainda possível identificar a expressão, um tanto mais tradicional, deste número: a oposição. Nestes casos, o par reforça uma dicotomia particular, reflectida nos fólios 49, 59, 64, 68v, 73 e 80, correspondentes às mensagens para as Igrejas de Éfeso, Pérgamo, Tiatira, Sardes, Filadélfia e Laodiceia, respectivamente. Nestas ilustrações, verdadeiramente contidas e simples (com excepção do fólio 64), apenas o par - anjo e apóstolo - prevalece da descrição apocalíptica, buscando assim representar, num estado mais puro, a passagem de testemunho entre um plano celeste e terrestre: o par que, sendo contrário na sua natureza (apesar da qualidade sacra de João), dá corpo à ligação entre ambos os mundos.

Concluímos também que o número dois se encontra associado a fenómenos e corpos celestes no manuscrito que nos ocupa. Falamos, pois, do binómio sol e lua, como símbolos perfeitos de dualismo. Caracterizam-se, portanto, pela sua natureza oposta, mas complementar, como uma síntese do universo criado que é luz e trevas, noite e dia, que é masculino e feminino. Corroborando estas ideias, nos fólios $115-O$ grande terramoto - e 139 (alusivo aos primeiros quatro toques da trombeta) observamos composições que reflectem a constância destes elementos nas visões apocalípticas. Frisamos ainda que no fólio $153 \mathrm{v}-A$ Mulher no sol e o dragão- os dois astros encontram-se sobre e sob a Mulher divina —os seus pés sobre a lua, símbolo e domínio feminino, e a sua cabeça sob o "sol derramante", associado ao divino masculino. ${ }^{191}$

Apesar destes serem conceitos ainda bastante gerais, cuja manifestação e significados reflectem essencialmente as descrições bíblicas, podemos compreender que este número demarca simbolicamente dinâmicas relacionais

191 Fernando RIGON, "Sole e luna, il binomio del cielo", in Arte dei Numeri - letture iconografiche, Milano, Skira, 2006, pp. 33-50. 
Ana de Oliveira DiAs, Commentarium in Apocalypsin: o número e a forma geométrica na tradição simbólica das ilustrações do «Beato» de São Mamede de Lorvão

diametralmente opostas (como a representação das relações entre o plano sagrado e o plano temporal nas imagens do anjo e do apóstolo); mas encontra-se também, bastantes vezes, associado a agentes divinos, criados em Deus, como seja a personificação da Igreja (representada por dois entes celestiais), os pares de anjos que respondem aos comandos divinos, ou mesmo a representação das duas testemunhas.

Apesar da sua vincada manifestação neste manuscrito, a interpretação deste número constitui o caso de maior dificuldade de análise neste estudo, não tanto pela sua ambiguidade, mas pela ausência de padrões evidentes, e específicos, como encontraremos no caso de outros números.

\section{De ternario numero}

Fundamental na visão aritmológica cristã, o número três detém um grande destaque na cópia [L]. Numa primeira instância, sugere o acto primordial da criação, a ligação à trindade e a multiplicação da natureza de Deus em pai, filho/homem e espírito. ${ }^{192}$ Santo Agostinho, como percursor desta analogia, revelou uma particular predilecção pelo sentido simbólico deste número, demonstrando-o pelo carácter tripartido pelo qual pautou toda a sua visão teológica e cosmológica. ${ }^{193}$

O primeiro de todos os ímpares constitui assim o produto da conjugação entre a unidade (1) e o par (2), estabelecendo-se como expressão da ordem sagrada, do domínio espiritual, do princípio, meio e fim. ${ }^{194}$ Deste modo, prende-se, neste manuscrito, essencialmente à representação de agentes e de elementos do plano divino e celestial, tal como à estruturação e definição de espaços nas ilustrações de página inteira.

Os fólios. $86,149 \mathrm{v}, 172 \mathrm{v}, 196 \mathrm{v}, 210^{195}$ reflectem esta última característica, em que uma clara tripartição das composições é verificável, na procura da demarcação dos diferentes planos cósmicos. $\mathrm{O}$ espaço intermédio que se formula entre o plano celeste e terreno, funciona como «via de comunicação», sendo um campo de acção reservado à teofania (fólio 210), à ascensão (fólio 149v), assim como à distinção e hierarquização das personagens presentes na ilustração (fólio 196v). Devemos ainda salientar que a divisão das iluminuras em bandas cromáticas segue a tendência tipológica dos manuscritos moçárabes, observandose este fenómeno num grande número de cópias do Comentário de Beato. ${ }^{196}$ Contudo, ressalvamos que esta tripartição não constitui uma regra, mas sim uma

\footnotetext{
192 AGOSTINHO DE HIPONA, De A Cidade de Deus [...], pp. 1011-1014.

${ }^{193}$ Sobre este assunto veja-se Jean-Pierre BRACH, p. 48. Três eram, igualmente, os sentidos da inteligência do Homem, essa que deveria ser pautada por um sentido e vertente histórica, moral e mística - ISIDORO HISPALENSIS, Liber Numerorum [...], p. 22.

${ }^{194}$ ISIDORO HISPALENSIS, Liber Numerorum [...], p. 18.

${ }^{195}$ Anexo iconográfico, Fig.42.

196 Sobre as características tipológicas dos manuscritos moçárabes destacamos o importantíssimo estudo de Mireille MENTRÉ, que constituiu um incontornável e precioso auxiliar para a análise que ora apresentamos.
} 
Ana de Oliveira DiAs, Commentarium in Apocalypsin: o número e a forma geométrica na tradição simbólica das ilustrações do «Beato» de São Mamede de Lorvão

opção estruturante e hierarquizante que demonstra ser frequente no modelo laurbanense.

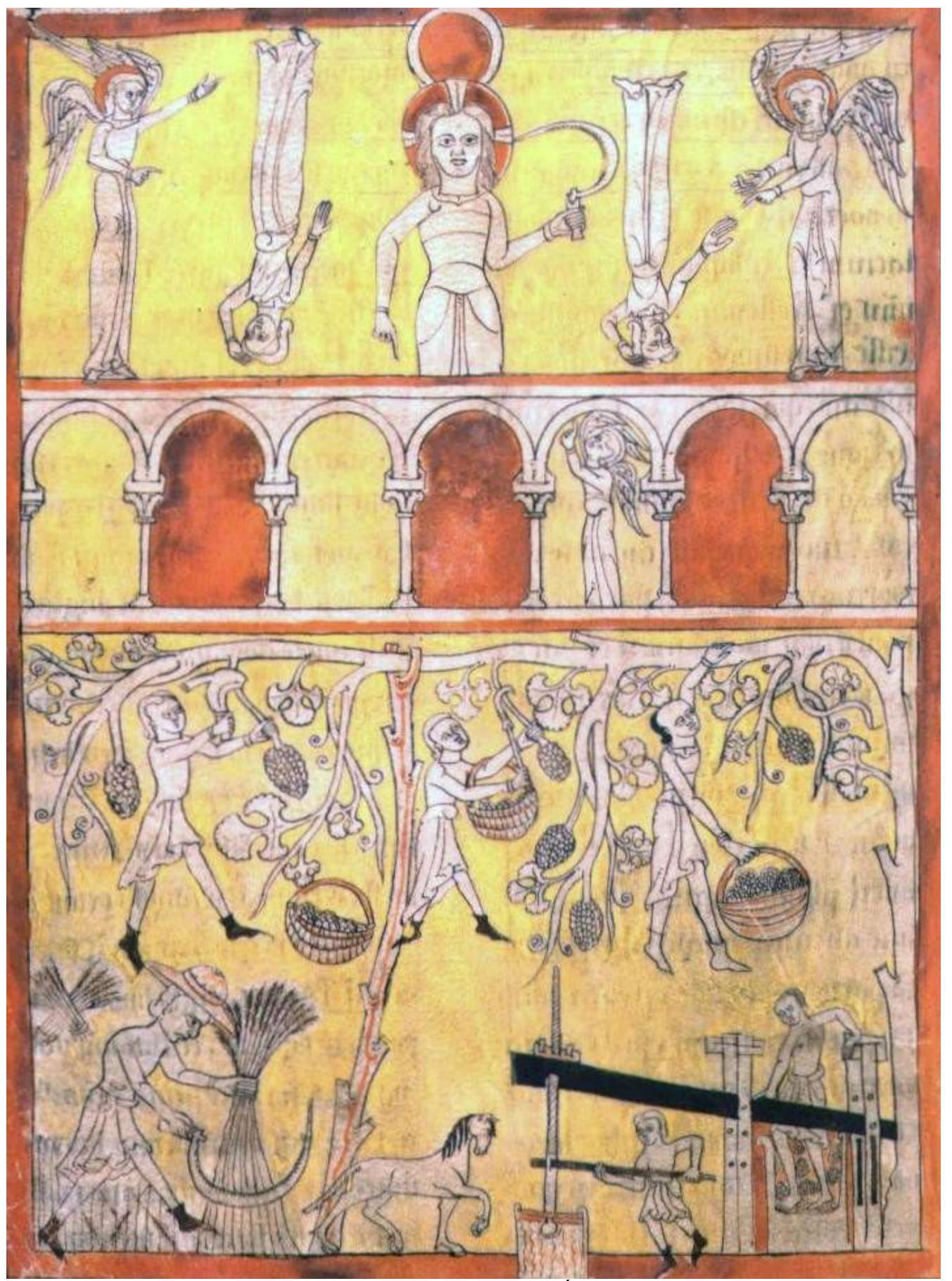

Fig. 10. Colheita e Vindima. Ap. 14, 14-20. BEATO DE LIÉBANA, Commentarium in Apocalypsin; cópia ilustrada do Mosteiro de São Mamede de Lorvão [...], fl. 172 v

A manifestação do número três é reconhecida, do mesmo modo, pela sua associação a figurações de agentes do bem, quando posicionados num nível transcendente. No fólio $172 \mathrm{v}$ - Colheita e Vindima - este aspecto torna-se claro. São três os anjos representados, encontrando-se claramente posicionados num plano superior a intermédio, tal como são três os vãos na loggia celestial (onde figura um dos anjos) individualizados com a aplicação de cor vermelha. Também 
Ana de Oliveira DiAs, Commentarium in Apocalypsin: o número e a forma geométrica na tradição simbólica das ilustrações do «Beato» de São Mamede de Lorvão

os fólios $86^{197}, 207$ e 217 reflectem uma prática análoga: no primeiro, três anciãos encontram-se junto a São João em êxtase, enquanto que no segundo fólio referido, três almas posicionam-se num plano superior sobre três tronos.

Ainda no fólio 217, destacamos a presença de três anjos no momento final de abnegação e fé do apóstolo de Patmos. Em todos estes casos o número três surge como atributo que relaciona e confirma a natureza celestial e sagrada destas personagens.Visando reforçar esta ideia, cumpre destacar o importantíssimo fólio 198 — Exército do céu ${ }^{198}$ — que se distingue das representações dos restantes «Beatos» pela figuração de somente três cavaleiros. Considerando que nenhuma referência numérica nos é oferecida quer pelo Livro da Revelação, quer pelo Comentário de Beato, a opção da figuração de três cavaleiros associados ao plano e domínio celeste deve-se possivelmente ao conhecimento e à evocação directa destes códigos numéricos transmitidos e herdados das doutrinas agostiniana e isidoriana, que se certamente influenciaram a construção do pensamento simbólico a este nível.

Um outro aspecto que consideramos que não deve ser ignorado quando analisamos a expressão deste número nos «Beatos» é a insistente referência à «terça parte». Essa constante apocalíptica é também verificada iconograficamente neste manuscrito que, por meio do método de divisões pretendeu corresponder fielmente aos episódios referidos nas Escrituras. No fólio 138 - a queima da terça parte da terra - o cálculo efectivo da terça parte é verificado no cuidado que o ilustrador demonstrou em dividir (quase que matematicamente) a área ilustrada em três partes, preenchendo a vermelhão a parcela abrasada.

Também no fólio 139 - o toque da quarta trombeta - a terça parte do sol, da lua e das estrelas é ferida (Ap 8, 12-13). Os dois círculos — símbolos dos dois astros principais- encontram-se, então, correctamente divididos, exibindo a negro (parte ferida) a porção correspondente à sua terça parte. Importante e quiçá sintomático, o já anteriormente referido fólio $153 \mathrm{v}$ apresenta-nos o dragão que com a sua cauda arrasta a terça parte das estrelas do céu (Ap 12,4). O ilustrador desta cópia representou a totalidade de trinta e cinco estrelas nesta iluminura, das quais doze se encontram totalmente cativas pela cauda da besta. Se calcularmos a terça parte do primeiro número $(35: 3=11,7=12)$ concluimos que, por meio do arredondamento por excesso de forma a obtermos um número inteiro (tal como as leis do cálculo determinam), temos precisamente o número doze como quociente. Poderá este aspecto constituir um acto intencional por parte do ilustrador na concepção do programa iconográfico da obra? Apesar de não o podermos afirmar taxativamente, levantamos porém esta questão de se o miniaturista responsável por esta iluminura (ou pelo modelo na sua base) estaria consciente da aproximação matemática, e da concretização rigorosa da divisão, aquando da composição deste episódio.

${ }^{197}$ Do ponto de vista da aplicação da cor constatamos que também neste fólio existe a intenção de evocar o número três através da cor, uma vez que as três áreas em que a estrutura se encontra dividida apresentam cores distintas - veja-se Anexo iconográfico, Fig. 42.

${ }^{198}$ Anexo iconográfico, Fig. 53. 


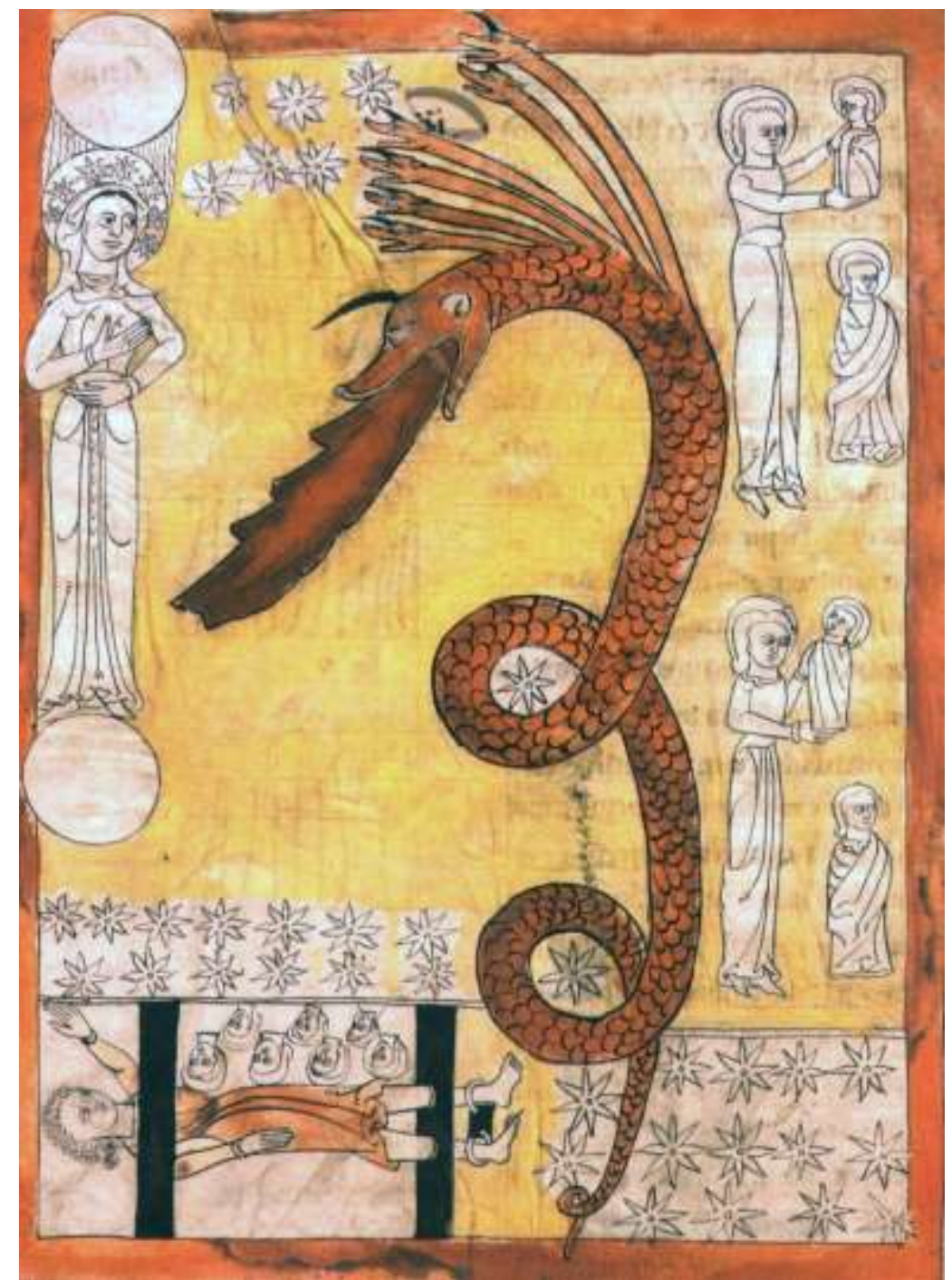

Fig. 11. A Mulher no Sol e o Dragão. Ap. 12, 1-18. BEATO DE LIÉBANA, Commentarium in Apocalypsin; cópia ilustrada do Mosteiro de São Mamede de Lorvão [...], fl. 153 v.

Também o fólio $184 \mathrm{v}$-O sétimo anjo derrama a taça pelo ar - proclama a divisão da grande cidade em três partes (Ap 16, 17-19), sendo esta debuxada de uma forma profundamente esquemática, através da mera separação, em três, dos blocos das muralhas da cidade. Esta ímpar iluminura contraria a tendência conhecida de todos os exemplares do Comentário - visualmente mais complexos e literais - e surge como um precioso testemunho da importância que a analogia numérica deteve na composição e assimilação destas storiae ilustradas, questão esta que retomaremos adiante.

Ressalvamos ainda que, para além dos aspectos mencionados, o número três, à semelhança do seu antecessor, reforça simbolicamente natureza de diversas personagens, objectos ou, até mesmo, de expressões (sonoras ou gestuais). A exaltação perfeita (e eficaz) cumpre uma «dinâmica ternária» e, nesta perspectiva, reinvocamos o fólio 139 que, tal como descrito no Livro do Apocalipse, ilustra foneticamente o som proferido, três vezes, pela águia - «Ve, $V e$, $V e \gg(A p 8,13)$ - através de uma pequena legenda na ilustração.

Num sentido lato, o número três evoca e caracteriza o domínio estritamente celeste e divino - agentes e entes sagrados afectos a um plano transcendente-, 
Ana de Oliveira DiAs, Commentarium in Apocalypsin: o número e a forma geométrica na tradição simbólica das ilustrações do «Beato» de São Mamede de Lorvão

assim como define e organiza estruturalmente o $\operatorname{cosmos}^{199}$, que se divide em três planos distintos, como vimos anteriormente. À luz destes exemplos, o número três assume-se como um conceito, arquétipo ou atributo de grande relevância tanto nesta obra como no imaginário medieval tout court, assumindo, porém, uma função claramente simbólica nestas miniaturas.

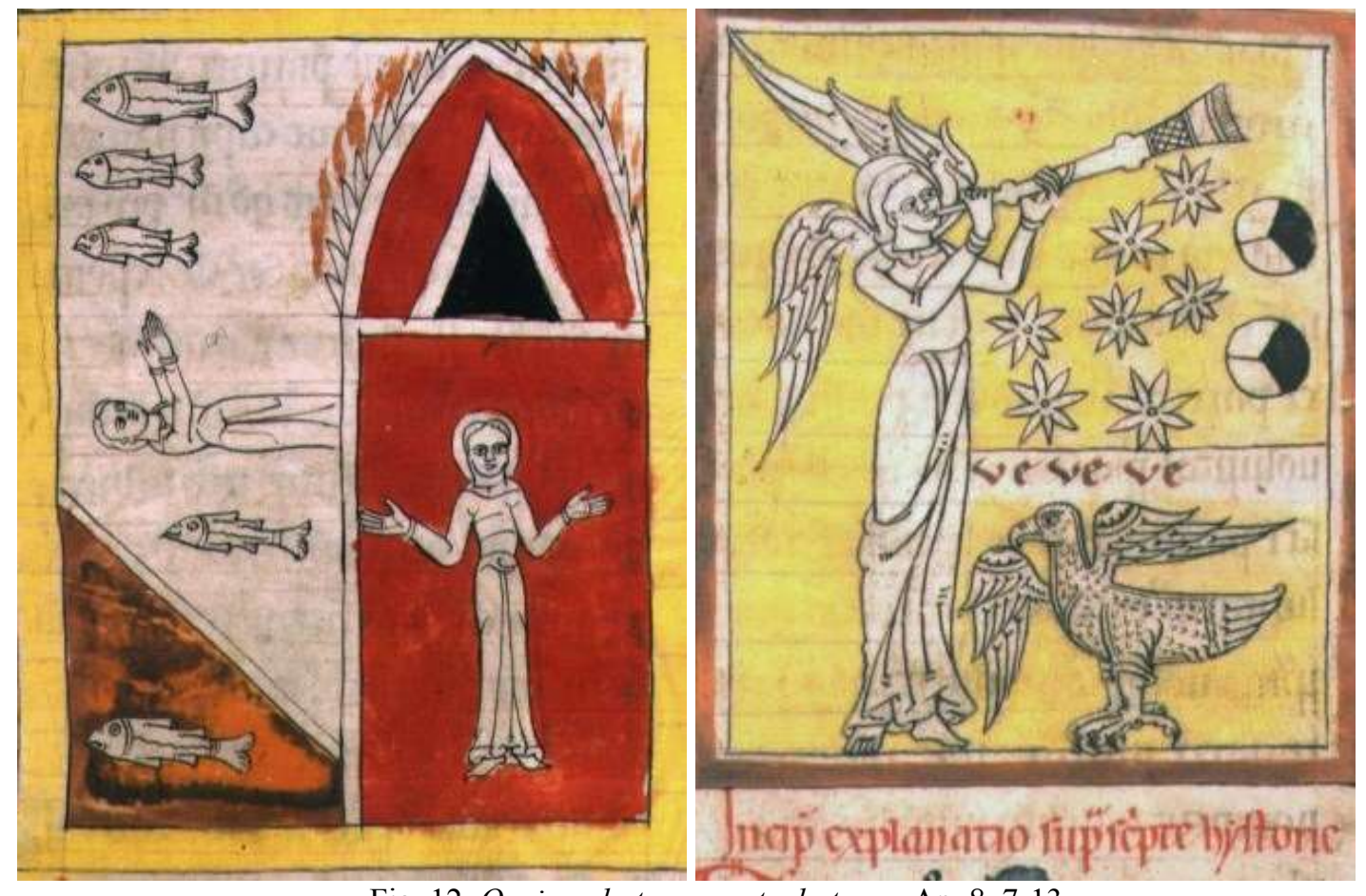

Fig. 12. Queima da terça parte da terra. Ap. 8, 7-13.

Fig. 13. Toque da quarta trombeta. Ap. 8, 7-13. BEATO DE LIÉBANA, Commentarium in Apocalypsin; cópia ilustrada do Mosteiro de São Mamede de Lorvão [...], fl. 138, 139.

\section{De quaternario numero}

É conhecido o sentido tangível ao qual se encontrou associado, desde a Antiguidade, o quarto de todos os números. A sua importância mística e simbólica é, pois, observável não somente no imaginário medieval, como também em diversos contextos espaço-temporais como número estruturante e afecto à ordem natural do mundo. Quatro são os pilares do universo, os elementos naturais (fogo, ar, terra, água), os pontos cardeais, as estações do ano ou os ventos. Quatro são também os humores do homem, os números da Tetráctis pitagórica, os braços da cruz, os rios do Paraíso, os mares, ou mesmo as letras que compõem o nome de Deus: $\mathrm{YHVH}^{200}$

${ }^{199}$ Cumpre salientar que um exemplo da ordenação do microcosmos à semelhança da qualidade numerológica do macrocosmos, constitui a própria organização e entendimento (tripartido) da sociedade medieval: oratores, bellatores e laboratores, como modelo de virtude e harmonia estrutural baseada nas três necessidades prementes da comunidade: oração, defesa e trabalho. Sobre este assunto veja-se George DUBY, As três ordens ou o imaginário do Feudalismo, Lisboa, Editorial Estampa, 1994.

200 Jean CHEVALIER, Alain GHEERBRANT, “Quatro" [...], pp. 554-556, ref. p. 554; ISIDORO HISPALENSIS, Liber Nvmerorvm [...], p. 30. 
Como produto da soma entre a unidade (1) e a trindade (3) - junção da potência criadora com o domínio espiritual - o número quatro representa a próxima dimensão: a terrestre. ${ }^{201} \mathrm{~A}$ sua associação ao domínio material conferelhe, então, esse pendor corpóreo, sensível e perecível, condições características do plano e mundo revelado.

Copiosamente citado no texto bíblico, encontra-se também revestido de um forte sentido de universalidade, sendo tido como arquétipo das realidades concretas. Sublinhamos que são ainda quatro os Evangelhos e os evangelistas, e quatro os cavaleiros que carregam as quatro grandes pragas, em quatro cavalos de quatro cores distintas. Desta forma, este número vincula-se a um plano concreto, físico, sobre o qual o ente divino manifesta e cumpre a sua acção e vontade.

Espelho das qualidades deste número foi de resto o Comentário laurbanense, tal como podemos constatar por meio dos gráficos anteriormente apresentados, onde verificamos que este número detém uma das mais elevadas percentagens de ocorrência. É no primeiro fólio iluminado $(12 \mathrm{v})$ que tomamos consciência da sua manifestação. De acordo com a passagem inicial do Apocalipse (Ap 1, 1), Deus encarregou de transmitir aos seus servos os eventos futuros, comunicando por meio do anjo que enviou a João. Apesar da Escritura não sugerir qualquer vínculo numérico, o anjo mensageiro encontra-se figurado exactamente quatro vezes nesta imagem, como agente do comando divino num plano terreno. ${ }^{202}$

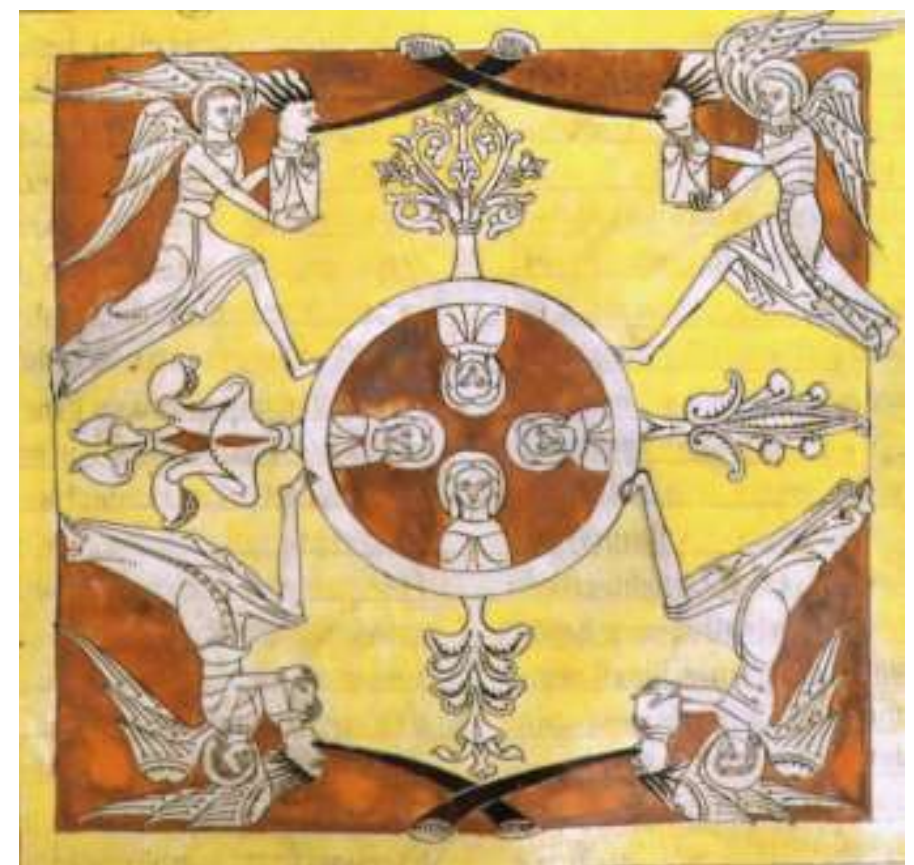

Fig. 14. Quatro anjos seguram os quatro ventos. Ap. 7, 1-3. BEATO DE LIÉBANA, Commentarium in Apocalypsin; cópia ilustrada do Mosteiro de São Mamede de Lorvão [...], fl. 118.

\footnotetext{
${ }^{201}$ Sobre este assunto veja-se Fernando RIGON, "Quadrature del tempo”, pp. 77 - 98.

202 Devemos salientar que esta foi uma opção apenas verificada na cópia de Lorvão, observando-se na grande maioria dos restantes exemplares a representação de apenas três anjos, com excepção dos exemplares de San Millán de Cogolla (um anjo), Turin (dois anjos, Berlin (um anjo), Arroyos (dois anjos).
} 
Ana de Oliveira DiAs, Commentarium in Apocalypsin: o número e a forma geométrica na tradição simbólica das ilustrações do «Beato» de São Mamede de Lorvão

Claro exaltador da dinâmica deste número, também o fólio 118 - Quatro anjos seguram quatro ventos - constitui um exemplo preciso desta questão. Tal como no episódio descrito (Ap 8, 1-3), são quatro os anjos que, assentes sobre os quatro cantos do mundo (que encerram quatro almas), carregam os quatro ventos, de modo a não danificar nem a terra, nem o mar, nem as árvores, igualmente representadas por quatro espécies distintas. Neste fólio, toda a composição alude aos elementos que incorporam a criação terrena (os ventos e as diferentes espécies), sustentada e apresentada pelos quatro enviados angélicos. ${ }^{203}$

Também no supracitado fólio 143, Deus estabeleceu que seriam quatro os anjos cativos sobre a terra (Ap 9, 13-15), reforçando-se novamente a ligação deste número a agentes que se situam sobre este plano e a seu serviço. Esta é uma figuração respeitada pela grande maioria dos «Beatos» remanescentes, dado ilustrar directamente o episódio e referência apocalíptica. ${ }^{204} \mathrm{Na}$ mesma perspectiva, no fólio $200-A$ Besta e os reis- são quatro as personagens identificadas como os reis da terra. ${ }^{205}$

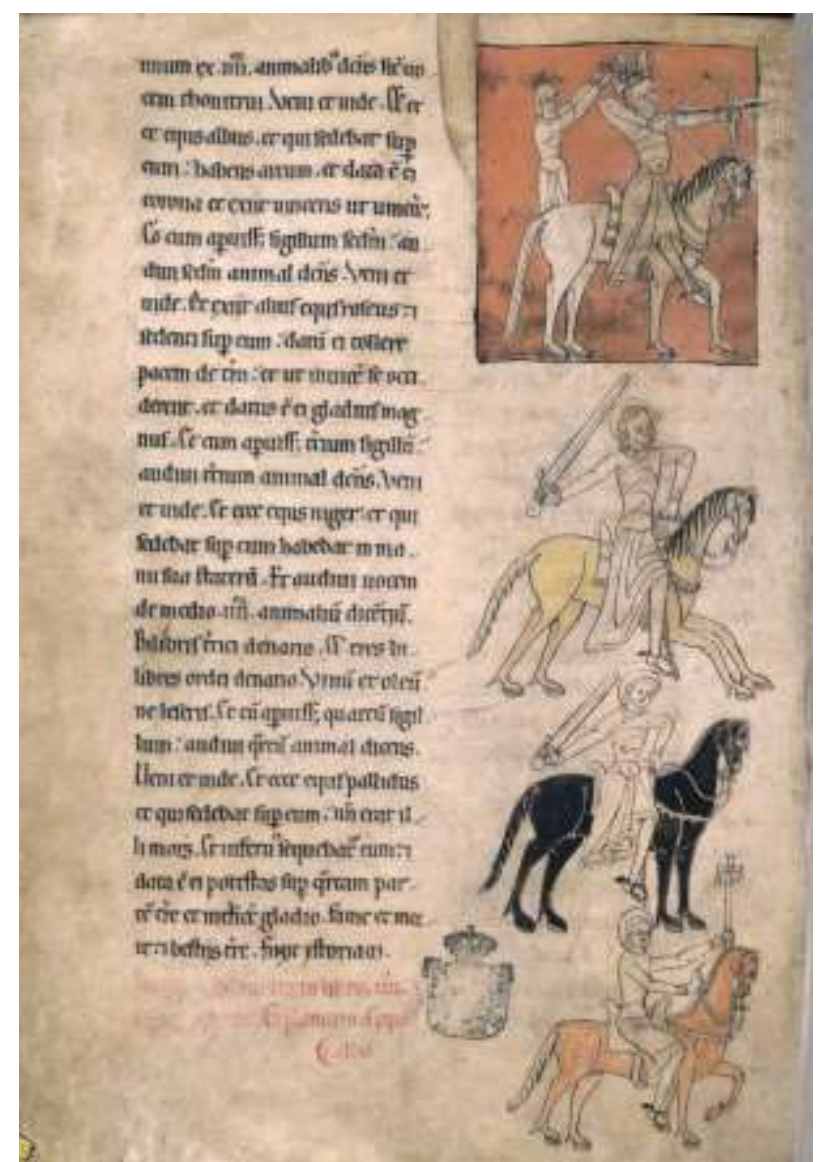

Fig. 15. Os quatro Cavaleiros. Ap. 6, 1-8. BEATO DE LIÉBANA, Commentarium in Apocalypsin; cópia ilustrada do Mosteiro de São Mamede do Lorvão [...], fl. 108v.

\footnotetext{
${ }^{203}$ Sobre este assunto veja-se ISIDORO HISPALENSIS, Liber Numerorum [...], pp. 28 e 30.

${ }^{204}$ Anexo iconográfico, Fig. 50.

${ }^{205}$ Anexo iconográfico, Fig. 54.
} 
Ana de Oliveira DiAs, Commentarium in Apocalypsin: o número e a forma geométrica na tradição simbólica das ilustrações do «Beato» de São Mamede de Lorvão

No entanto, um dos momentos mais enigmáticos da visão de João ganha corpo no fólio $108 \mathrm{v}$, onde figuram os grandes líderes das hostes apocalípticas. Falamos pois dos quatro cavaleiros do Apocalipse, aqueles que mediante a abertura dos quatro primeiros selos se lançam sobre a terra, purgando-a dos pecados da humanidade. ${ }^{206}$ Cremos que se estabelece assim uma clara relação entre o número e a ilustração, funcionado este como atributo das próprias personagens. Frisamos como reforço e exemplo desta ideia, a diferenciação base entre os fólios $108 \mathrm{v}$ e 198 , em que ambos representam um exército, porém, de natureza e propósito distintos, sendo essa mesma natureza declarada através do atributo numérico. $\mathrm{O}$ número três (vinculado então à dimensão celeste), caracteriza assim o exército que combate e existe unicamente nesse plano (fólio 198), enquanto que o número quatro qualifica o exército que actua sobre o plano temporal, ainda que sob ordem manifesta de Deus (fólio 108v).

De resto, no nosso ponto de vista, esta constitui a diferença conceptual entre ambos os números, encontrando-se estes, enquanto atributos, claramente ao serviço da mensagem veiculada nesta obra. Outros exemplos semelhantes, seguidores de um princípio análogo, podem ser identificados nos fólios 142 e 144 (História dos gafanhotos e os Cavalos com cabeças de Leões, respectivamente).

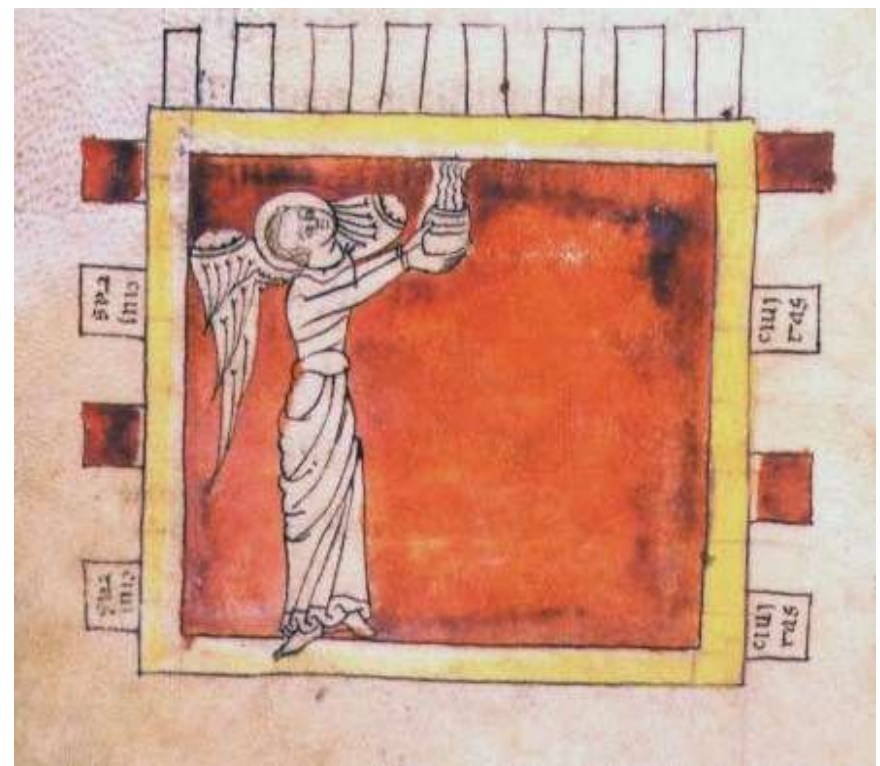

Fig. 16. O sétimo anjo derrama a taça pelo ar. Ap. 16, 17-19. BEATO DE LIÉBANA, Commentarium in Apocalypsin; cópia ilustrada do Mosteiro de São Mamede de Lorvão [...], fl. 184v.

206 Tal como descrito no Livro do Apocalipse e no seu Comentário, a abertura dos quatro primeiros selos é caracterizada pelo aparecimento de quatro cavaleiros, cada qual com as suas respectivas valências, funções e atributos, constituindo esta uma ilustração comum a todas as cópias completas que conhecemos da obra de Beato. Contudo, o exemplar de Lorvão exibe um pormenor que merece ser ressalvado. Apesar das suas semelhanças formais com o «Beato» [O], o códice laurbanense distingue-se então pela inclusão e individualização do primeiro cavaleiro num quadrado laranja. Indo ao encontro do que afirmou Silva Rocha, este facto pode dever-se à necessidade da criação de um contraste cromático (e evidente exaltação das qualidades simbólicas deste cavaleiro) entre a superfície do pergaminho e a figuração do cavalo, visto ser, de acordo com as fontes, o equus albus que representaria a Igreja e a luta pelo seu triunfo na terra (característica que cremos reforçada pelo quadrado) - Jorge da Silva ROCHA, p.247. 
Ana de Oliveira DiAs, Commentarium in Apocalypsin: o número e a forma geométrica na tradição simbólica das ilustrações do «Beato» de São Mamede de Lorvão

De fundamental importância para o entendimento da relevância numerológica neste códice, o fólio $184 \mathrm{v}$ demonstra uma estreita ligação com esta linha interpretativa. Ilustrando a destruição da cidade - baluarte físico de criação humana -, constatamos que o iluminador compôs esta imagem através da inserção do anjo num quadrado vermelho, rodeado por um total de dezasseis blocos divididos em três partes $(8+4+4)$, onde inscreveu quatro vezes (no interior de quatro blocos) a palavra Ciuitas. Por oposição aos restantes exemplares ilustrados da obra de Beato de Liébana - aparatosos, quase cénicos a cópia portuguesa - na sua simplicidade e depuramento - recorre ao número, e a uma composição muito mais simbólica e conceptual, para expressar o significado desta passagem. Numa primeira instância divide rigorosamente os blocos em três partes (tal como mencionado em Ap 16, 17-19), seguindo-se o emprego do código numérico - quatro- para a expressão da natureza dimensional do espaço evocado. ${ }^{207}$

Consideramos por fim, que a constante exaltação deste número no presente manuscrito, deve a sua razão de ser ao próprio carácter do Livro da Revelação e do seu Comentário: o relato e interpretação das visões de São João evangelista acerca dos acontecimentos últimos, e das consequências da cólera e juízo divino sobre o mundo revelado. Assim, considerando o sentido simbólico associado a este número no imaginário cristão, compreendemos que a sua constante evocação nas ilustrações deste manuscrito espelha e transmite essa relação entre a natureza e o significado dos eventos descritos.

\section{De senario numero}

Senarius namque [numerus] qui partibus suis perfectus est, perfectionem mundi quadam numeri [sui] significatione declarat ${ }^{208}$, assim nos apresentou Isidoro de Sevilha o sexto número da primeira dezena, à luz da teologia altomedieval, da qual Beato se considerou herdeiro e cultor.

Seis deve a sua origem e natureza à soma dos factores 1,2 e 3 , ou seja, dos três números primordiais. Entendido como número perfeito -a «perfeição das obras $»^{209}$-, este relaciona-se com o processo geracional, definindo a medida e comprimento de todas as coisas existentes. Frisamos que seis foram os dias e etapas da Criação; que seis corresponde à medida da partição do círculo ${ }^{210}$, tal como a cronometragem cíclica da História do universo (Sexta Idade). Perante esta evidente profundidade espiritual, não nos surpreende a sua presença considerável nas ilustrações deste «Beato», podendo ser observado, enquanto padrão iconográfico, nos fólios $14 \mathrm{v}, 172 \mathrm{v}$ e 199 . Atentando sobre a primeira

\footnotetext{
${ }^{207}$ A ligação ao número quatro e ao plano terrestre é igualmente exaltado na descrição bíblica da Jerusalém Celeste. De acordo com a fonte, esta detinha quatrocentas e quarenta e quatro léguas - o quatro repetido três vezes: 444 - acentuando essa relação da construção e manifestação do desígnio divino sobre o plano terrestre (Ap 22, 16).

${ }^{208}$ ISIDORO HISPALENSIS, Etimologias [...], p. 426.

${ }^{209}$ AGOSTINHO DE HIPONA, A Cidade de Deus [...], pp. 1063 e 1064.

${ }^{210}$ Jean-Pierre BRACH, p. 48.
} 
imagem, são seis os homens figurados sobre o plano terrestre e seis as almas representadas nos céus, ambos em contemplação da imagem de Cristo. Aqui, uma clara dicotomia entre a realidade física e celestial é estabelecida - como espelho - como que em rememoração da totalidade da grande obra divina. Seis é, portanto, o número chave que estabelece essa metáfora, visando distinguir e demarcar o criador das criaturas, o genitor dos produtos da geração.

Seguindo um mesmo discurso, o fólio $172 \mathrm{v}$ exalta essa mesma diferenciação. Esta notável iluminura (que representa o episódio apocalíptico da cólera de Deus e da grande ceifa) exibe uma estrutura tripartida na qual observamos no plano inferior um grupo de seis homens dedicados a actividades agrícolas — ceifa e vindima-, numa interessante representação das técnicas e práticas deste período. A escolha do número de personagens não nos parece portanto casual, pretendendo certamente estabelecer uma relação entre o processo descrito e a obra divina, ou simplesmente remeter e caracterizar - como analogia - o grupo de laboratores como elementos activos do universo criado (em seis etapas), ao serviço de Deus.

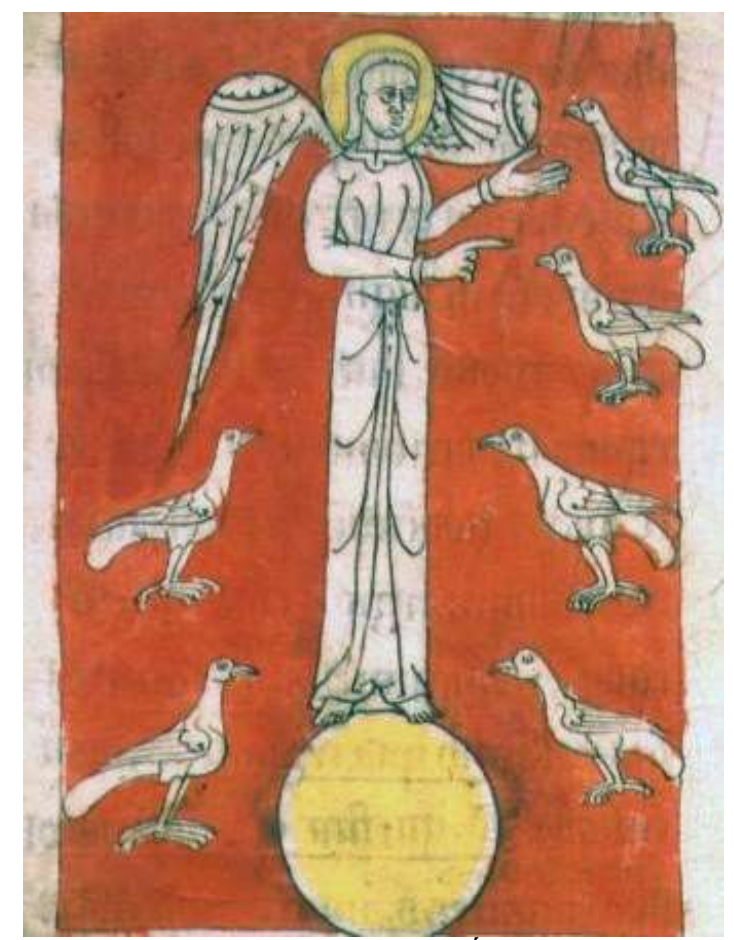

Fig. 17. O anjo sobre o sol. Ap. 19, 17-18. BEATO DE LIÉBANA, Commentarium in Apocalypsin; cópia ilustrada do Mosteiro de São Mamede de Lorvão [...], fl. 199.

O fólio 199 - o anjo sobre o sol— reflecte uma ordem semelhante. O número encontra-se vinculado à periodização de actos e etapas, sendo os seis pássaros debuxados, os agentes de um dos actos «degenerativos» comandados por Deus. Estas aves, aclamadas pelo anjo, reuniram-se assim para o grande banquete; saciar-se-iam com as carnes de todos os infames: reis, generais, poderosos, cavalos, cavaleiros, de todos «livres e escravos, pequenos e grandes» terminando, deste modo, o rol de condenados. Se atentarmos sobre este excerto são seis as nomeações discriminadas, seis os comandos vocais às quais cada ave —uma por uma- deveria obedecer (Ap 19, 19-21). Cumpre referir que esta cópia 
Ana de Oliveira DiAs, Commentarium in Apocalypsin: o número e a forma geométrica na tradição simbólica das ilustrações do «Beato» de São Mamede de Lorvão

demonstra ser única quanto à quantidade de espécies avícolas representadas, parecendo assim demonstrar uma maior fidelidade à fonte e um maior peso atribuído à componente numérica.

Os restantes manuscritos — particularmente das famílias IIa e IIb - para além de uma maior diversificação das espécies apresentadas, não denotam qualquer padrão quanto ao número de elementos na composição. Apenas o «Beato» $[\mathbf{O}]$ se aproxima do modelo [L] (ainda que apenas estilisticamente), não sendo, porém, unânimes na escolha do número de aves.

Assim, estas particularidades iconográficas da cópia de Lorvão podem então constituir evidência de uma maior fidelização a uma tradição e modelo mais antigo, por certo arreigado a um espírito verdadeiramente ascético, mais constrito estilisticamente e próximo dos métodos de Beato e do seu antecessor Isidoro, no tocante à especulação numérica.

Todavia, do mesmo modo que este número se coaduna a um arquétipo de perfeição - a união entre o ente divino e o produto da sua obra - a natureza dual dos símbolos faz com que também se relacione com aspectos contrários à ordem natural e à criação divina. ${ }^{211}$ Se olharmos para o Livro da Revelação, o número seis possui um significado maioritariamente pejorativo, sendo aquele que, exaltando e repetido três vezes, origina o número do Anticristo: 666.

Após uma primeira análise e abordagem, tornou-se necessário o confronto com as fontes textuais e iconográficas de modo a confirmar esse carácter dúplice neste códice. Desta forma, no fólio 182 - Os espíritos imundos - são seis os agentes maléficos representados, tal como seis são os espíritos «semelhantes a rãs» (Ap 16,13-14) que saem das suas bocas. ${ }^{212}$ Cumpre referir que este padrão é também seguido pelos «Beatos» $[\mathbf{E}]$ e $[\mathbf{N}]$.

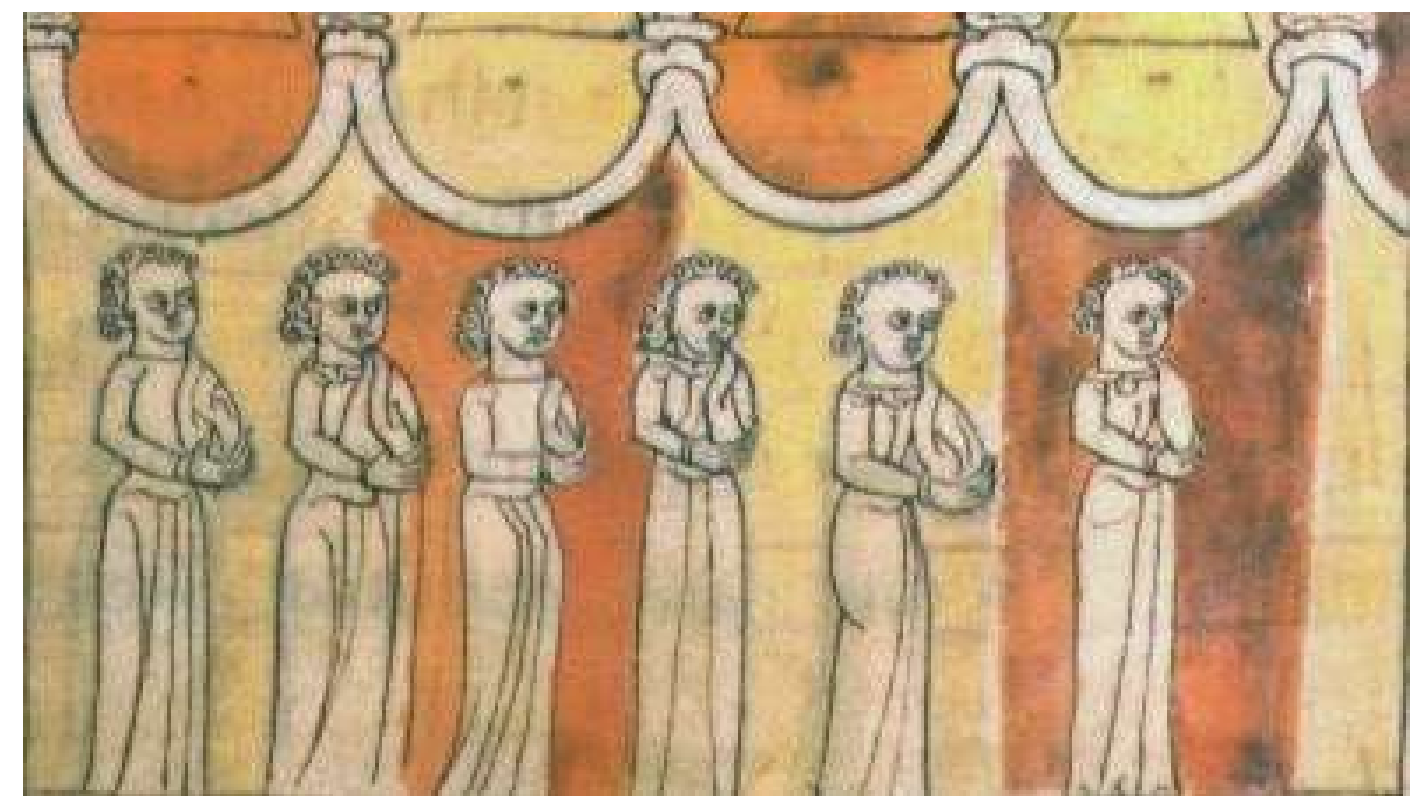

Fig. 18. A queda da Babilónia. Ap. 18, 1-19. BEATO DE LIÉBANA, Commentarium in Apocalypsin, cópia ilustrada do Mosteiro de São Mamede de Lorvão [...], fl. 193.

\footnotetext{
${ }^{211}$ Jean CHEVALIER, Alain GHEERBRANT, “Seis” [...], pp. 591-592, ref. p. 591.

${ }^{212}$ Anexo iconográfico, Fig. 51.
} 
É, de igual modo, seis o número que qualifica os usurpadores figurados no fólio 193, referente ao episódio da queda da Babilónia. Desprovido de qualquer constrangimento espacial, é evidente a intencionalidade do ilustrador (seja da cópia de Lorvão, seja do modelo que esteve na sua origem) na escolha exacta de seis elementos para a figuração dos representantes do mal, à imagem das restantes composições deste carácter.

Uma outra situação semelhante é ainda verificável no fólio 200: a besta, o falso profeta e os quatro reis adoradores ${ }^{213}$ compõem esta ilustração, perfazendo, uma vez mais, a soma de seis personagens. ${ }^{214}$

Compreendemos assim que estas composições, para além de partilharem o mesmo padrão numérico, compartilham, com exactidão, o mesmo teor e carácter: a associação a representações de agentes maléficos. Estabelece-se assim uma correlação e correspondência directa entre este número e o presente arquétipo, levando-nos a compreender e a validar uma dupla natureza associada a este número - de perfeição e mal, de ordem e caos-, como podemos verificar, iconograficamente, no exemplar que nos ocupa.

\section{De septenario numero}

$\mathrm{Da}$ união entre o domínio celeste e terrestre, entre o ímpar e o par «completos» ${ }^{215}(3+4)$ surge o número sete ${ }^{216}$, o quarto de todos primos, que incorpora o estatuto da plenitude e da totalidade universal. Segundo o bispo de Hipona - que diversas considerações teceu em torno deste algarismo, constante na literatura apocalíptica ${ }^{217}$ - , sete mede o tempo total da História e o percurso dos homens na terra: os seis ciclos somados a um ciclo de espera e conclusão, como reflexo do próprio acto da Criação que nos é descrito como o processo de seis dias mais um, para o descanso e distinção de Deus em relação à sua obra. ${ }^{218}$ Seis é, portanto, o número das etapas que, coroado pela unidade $(6+1)$, representa as noções de totalidade e inteireza. ${ }^{219}$

No seu sentido lato, o número sete caracteriza diferentes aspectos da ordem espiritual, moral e física: sete são as virtudes (três teologais, quatro cardeais), o número da ordem angélica, ou dos ciclos lunares. Reúne também em si um sentido de transmutação, finalização e encerramento de ciclos temporais e rituais, constituindo exemplo os episódios bíblicos da libertação e absolvição dos escravos e devedores por cada ciclo de sete anos, ou mesmo a duração da

${ }^{213}$ Proposta iconográfica de Anne d'EGRY, p. 99; Jorge da Silva ROCHAR, p.640.

${ }^{214}$ Verificamos que algumas cópias da família IIa, como (V), (U) e (J) apresentam igualmente o total de seis agentes maléficos representados na ilustração.

${ }^{215}$ AGOSTINHO DE HIPONA, A Cidade de Deus [...], p. 1065.

${ }^{216}$ IDEM, ibidem, p. 1065.

${ }^{217}$ IDEM, ibidem, pp. 1005 e 1006.

${ }^{218}$ Jean CHEVALIER, Alain GHEERBRANT, “Sete” [...], pp. 603-606, ref. p. 603.

${ }^{219}$ ISIDORO HISPALENSIS, Liber Numerorum, p.44. 
Ana de Oliveira DiAs, Commentarium in Apocalypsin: o número e a forma geométrica na tradição simbólica das ilustrações do «Beato» de São Mamede de Lorvão

construção do templo de Salomão (I Reis, 6, 38). ${ }^{220}$ Foi assim tido como um número de lei ${ }^{221}$ que estabelece o percurso para a salvação. ${ }^{222}$

Dada a profundidade do seu discurso místico, diversas foram as vezes que encontramos o «espírito septiforme» ${ }^{223}$ nomeado no Comentário de Beato de Liébana, numa constante exaltação dos septenários divinos. Estreitamente relacionado com agentes e corpos celestiais, tal como com estruturas arquitectónicas divinas, são diversos os fólios iluminados contemplados com a sua presença, sendo entre todos os algarismos considerados neste estudo o que que mais fielmente se relaciona e respeita as fontes textuais.

No «Beato» $[\mathbf{L}]$ observamos o primeiro grupo de septenários no fólio 17 que justamente ilustra uma das primeiras visões do evangelista: os sete candeeiros de ouro, as sete estrelas sobre a mão direita do que se intitula o «primeiro e o último» (Ap 1,20). Sete são também os anjos que, sob o comando da palavra divina, executam as suas sentenças, dando-nos a conhecer os instrumentos e atributos - taças, selos, trombetas - igualmente caracterizados por este número. Os fólios 135 e 175 representam precisamente os objectos mencionados: a hoste dos sete anjos apocalípticos, exibindo as sete trombetas da anunciação dos flagelos (fólio 135) ou as sete taças de ouro (cheias) da cólera de Deus (fólio 175).

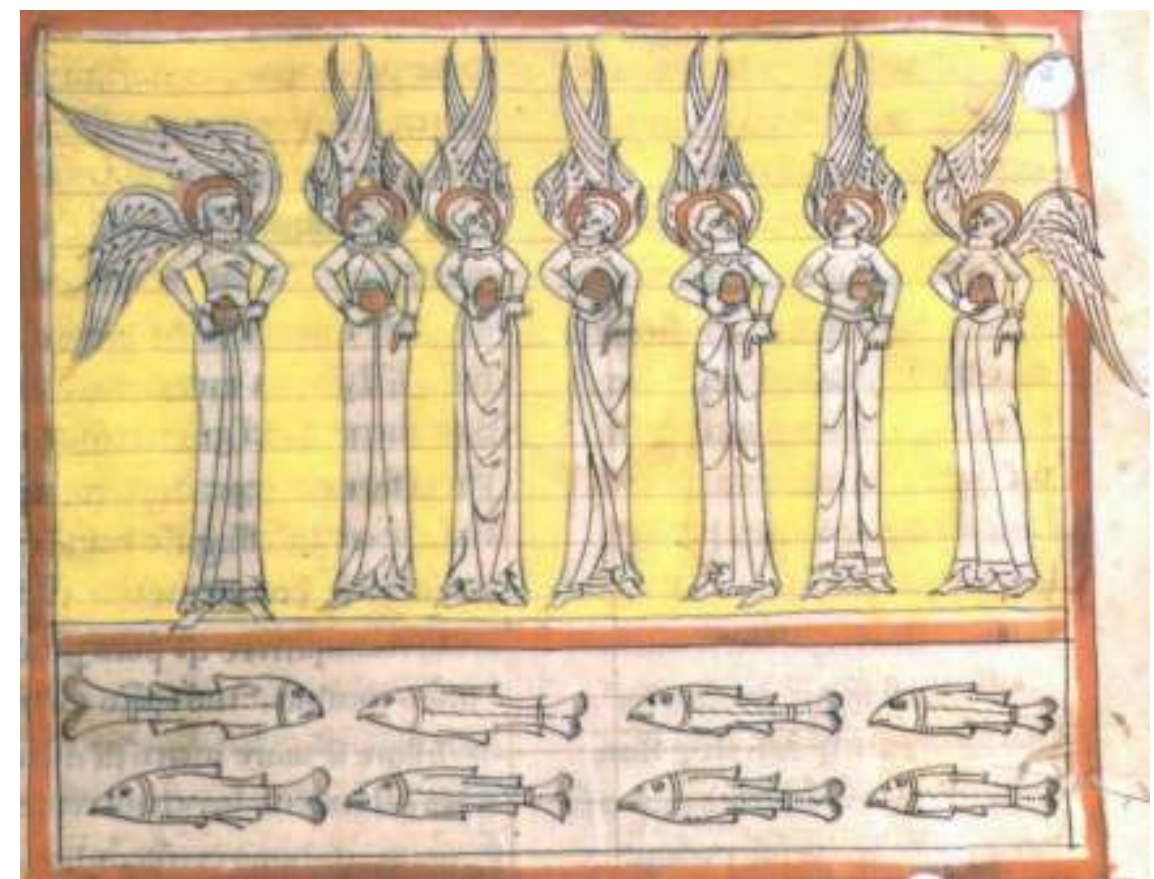

Fig. 19. Sete anjos derramando as taças da cólera de Deus. Ap. 15, 1-8. BEATO DE LIÉBANA, Commentarium in Apocalypsin; cópia ilustrada do Mosteiro de São Mamede de Lorvão [...], fl. 175.

\footnotetext{
${ }^{220}$ IDEM, ibidem, p. 604.

${ }^{221}$ ISIDORO HISPALENSIS, Liber Numerorum [...], p. 42.

${ }^{222}$ Sobre a natureza geral deste número veja-se Fernando RIGON, "Settenari di sintesi”, pp. 117-196.

${ }^{223}$ Termo ou expressão aplicada por Isidoro de Sevilha - ISIDORO HISPALENSIS, Liber Numerorum [...], p. 46.
} 
Ana de Oliveira DiAs, Commentarium in Apocalypsin: o número e a forma geométrica na tradição simbólica das ilustrações do «Beato» de São Mamede de Lorvão

Invocando uma vez mais o fólio 86, e incidindo sobre a banda cromática superior, constatamos que, na impossibilidade da representação dos vinte e quatro anciãos, são sete as personagens figuradas na ilustração laurbanense: seis identificadas como anciãos e Cristo, numa equação que compreende a dinâmica $6+1=7$, constituindo assim este padrão numérico um atributo que atesta e confirma a santidade destas personagens.

No fólio $153 \mathrm{v}$ detectamos um outro fenómeno único e deveras interessante. Para além da representação dos sete anjos cativos juntamente com o demónio, são sete as estrelas que compõe a coroa da Mulher na ilustração laurbanense (Ap 12, 1). Apesar do texto do Livro do Apocalipse mencionar o adorno de doze estrelas em concreto, o ilustrador de Lorvão (ou da cópia que terá constituído o seu modelo) optou claramente pela figuração deste número de elementos na impossibilidade de ilustrar as doze estrelas na coroa da Mulher. Esta, como figura fulcral que dá à luz a Igreja, perfeita e santa, adornada com as sete estrelas divinas afronta, assim, a besta de sete cabeças, num confronto directo, entre as forças do bem e do mal. Este exemplo demonstra como o conteúdo simbólico e escatológico destas iluminuras precede, em diversos momentos, a própria descrição da fonte.

Por outro lado, à semelhança do seu antecessor, o número sete associa-se brevemente ao universo maléfico. Referimo-nos pois à besta apocalíptica com as suas sete cabeças, sendo esta encarada, à luz desta tradição, como fenómeno de imitação ou corruptela da obra divina. Nesta perspectiva também no fólio 43 Mulher sobre a besta - podemos observar sete símbolos (até agora indecifráveis) junto à grande meretriz, filiados certamente ao arquétipo maléfico, dada a natureza iconográfica da ilustração.

Como referimos previamente, encontramos este número ainda associado a estruturas arquitectónicas. No fólio 17 os sete arcos debuxados simbolizam as sete Igrejas da Ásia, cujos nomes surgem figurados sobre cada volta. Verificamos, porém, a mesma tendência na derradeira ilustração no fólio $217 \mathrm{v}$, e ainda que nenhuma relação concreta seja estabelecida com estas Igrejas, o padrão numérico é continuado e são setes os arcos que dividem o céu e a terra nesta ilustração; este aspecto corrobora, uma vez mais, o carácter divino e de plenitude associados a estes número.

Deste modo, este número assume-se no presente manuscrito como o mais fielmente relacionado com as descrições do Apocalipse. A sua extrema importância no «imaginário bíblico» transformam-no num número incontornável, cuja figuração é impreterivelmente cumprida aquando da sua menção textual, não legando margens para interpretações ou desvios por parte dos ilustradores, como constatamos com determinados números anteriormente citados. Salientamos ainda que todas as composições dominadas por este número pertencem, sem excepção, ao grupo de ilustrações que seguem e respeitam a descrição bíblica. ${ }^{224}$ Assim, comum a todas as cópias e fragmentos expressivos, sobreviventes à voragem dos tempos, o sete afirma-se como símbolo inexorável da totalidade e

${ }^{224}$ Como podemos constatar ao observamos os fls. 17 (Ap 1, 10-20), 135 (Ap 8, 2-6), 175 (Ap 15. 1-8), 217v. (Ap 22, 16-20). 
Ana de Oliveira DiAs, Commentarium in Apocalypsin: o número e a forma geométrica na tradição simbólica das ilustrações do «Beato» de São Mamede de Lorvão

do domínio divino, assumindo portanto um papel de compreensível destaque à luz, e no contexto, desta obra e das preocupações quiliásticas vividas pela comunidade de Lorvão.

\section{De duodenario numero}

Apesar de evidenciar uma menor ocorrência, o número doze ocupa indubitavelmente um lugar de particular destaque nos fólios do Comentário laurbanense.

Devendo a sua origem à multiplicação do três pelo quatro -partes constituintes do número sete ${ }^{225}$ —, este é também um número totalizador, que incorpora o estágio final de aglomeração entre as obras celeste e terrestre. ${ }^{226}$ Assim, encontramo-lo de modo genérico associado a um conjunto de realidades também em si totalizantes, como os doze signos do Zodíaco (considerados desde a Antiguidade, ou mesmo os doze meses do ano litúrgico. À semelhança do número sete, este associa-se ao culminar de ciclos, assumindo, porém, um carácter mais permanente e definitivo, como a afirmação de um estágio alcançado pós-término.

Biblicamente, o seu peso é notório. Nomeado múltiplas vezes, este é o número das doze tribos de Israel, dos Patriarcas, dos apóstolos de Cristo ${ }^{227}$, caracterizando-se por um sentido de escolha, de eleição (o número dos Eleitos). Participando também do significado de Igreja, é o número que caracteriza a Jerusalém Celeste e todas as suas qualidades inerentes.

Desta forma, é justamente nas iluminuras referentes a estas passagens e episódios que nos deparamos com este algarismo que, apesar de se manifestar apenas quatro vezes no total das ilustrações, constitui, ainda assim, um padrão assinalável.

No fólio 146 - medição do novo templo pelo apóstolo de Patmos - são representadas as diferentes etapas do processo laboral do visionário. Observamos que são exactamente doze as personagens que compõem esta imagem e - ainda mais interessante e sintomático - a vara de medição com qual o apóstolo mede a altura do templo (do chão até ao limite da estrutura abobadada), encontra-se seccionada em precisamente doze partes. Estes aspectos levam-nos assim a intuir uma relação premeditada entre o conteúdo temático deste episódio e o número associado. ${ }^{228}$ Doze une-se então à ideia de templo, de concretização e triunfo do santuário divino sobre a terra e o céu.

Apenas comum aos «Beatos» [L], [B] e [N], os fólios. 208v e 209 apresentam o lapidário: as doze jóias ou gemas sagradas da Nova Jerusalém - jaspe, safira, calcedónia, esmeralda, sardónica, sárdio, crisólito, berilo, topázio, crisópraso,

\footnotetext{
${ }^{225}$ AGOSTINHO DE HIPONA, A Cidade de Deus [...], p. 1392.

${ }^{226}$ Jean CHEVALIER, Alain GHEERBRANT, “Doze” [...], p. 272, ref. p. 272.

${ }^{227}$ AGOSTINHO DE HIPONA, De A Cidade de Deus [...], p. 1392.

${ }^{228}$ Cumpre referir que esta relação não constitui um padrão ou modelo entre os restantes manuscritos desta natureza. Somente o «Beato» de Girona cumpre precisamente o mesmo número de figuras que a cópia de Lorvão. Veja-se Anexo iconográfico, Fig. 41.
} 
jacinto e ametista. (Ap 21, 18-20). Apesar de divididas por dois fólios, visam ilustrar directamente o texto do Comentário, iniciando os pontos referentes às valências de cada uma das pedras sagradas. Uma vez mais, reconhecemos que o número doze se manifesta neste códice como caracterizador do conceito de Igreja, e por associação às ideias e representações do seu triunfo e júbilo, como podemos verificar no fólio $209 \mathrm{v}$. Este exibe, com toda a sumptuosidade, a Nova Jerusalém que constitui a máxima exaltação deste conceito. Cumprindo a descrição bíblica, desdobra-se e multiplica-se, exibindo doze esferas como as doze portas, em relação com os quatro pontos cardeais - cada três portas por cada ponto -, ou seja a equação $3 \times 4$ (Ap 21, 13). De acordo com a visão do apóstolo, observamos os doze anjos como guardiões das doze portas, representados como personagens não aladas. Assim, envolvido por uma malha quadrangular, constituída por duzentas e vinte quadrículas, o apóstolo mede o templo certificando-se dos seus cento e quarenta e quatro côvados de altura: o quadrado perfeito $12^{2}$ (Ap 21, 17). Devemos ainda ressalvar o pormenor da vara de medição utilizada pelo apóstolo que, à semelhança da que se encontra no fólio 146, foi cuidadosamente dividida em doze secções exactas de modo a transmitir, de forma fiel e rigorosa, a medida sagrada aplicada na concepção destes espaços.

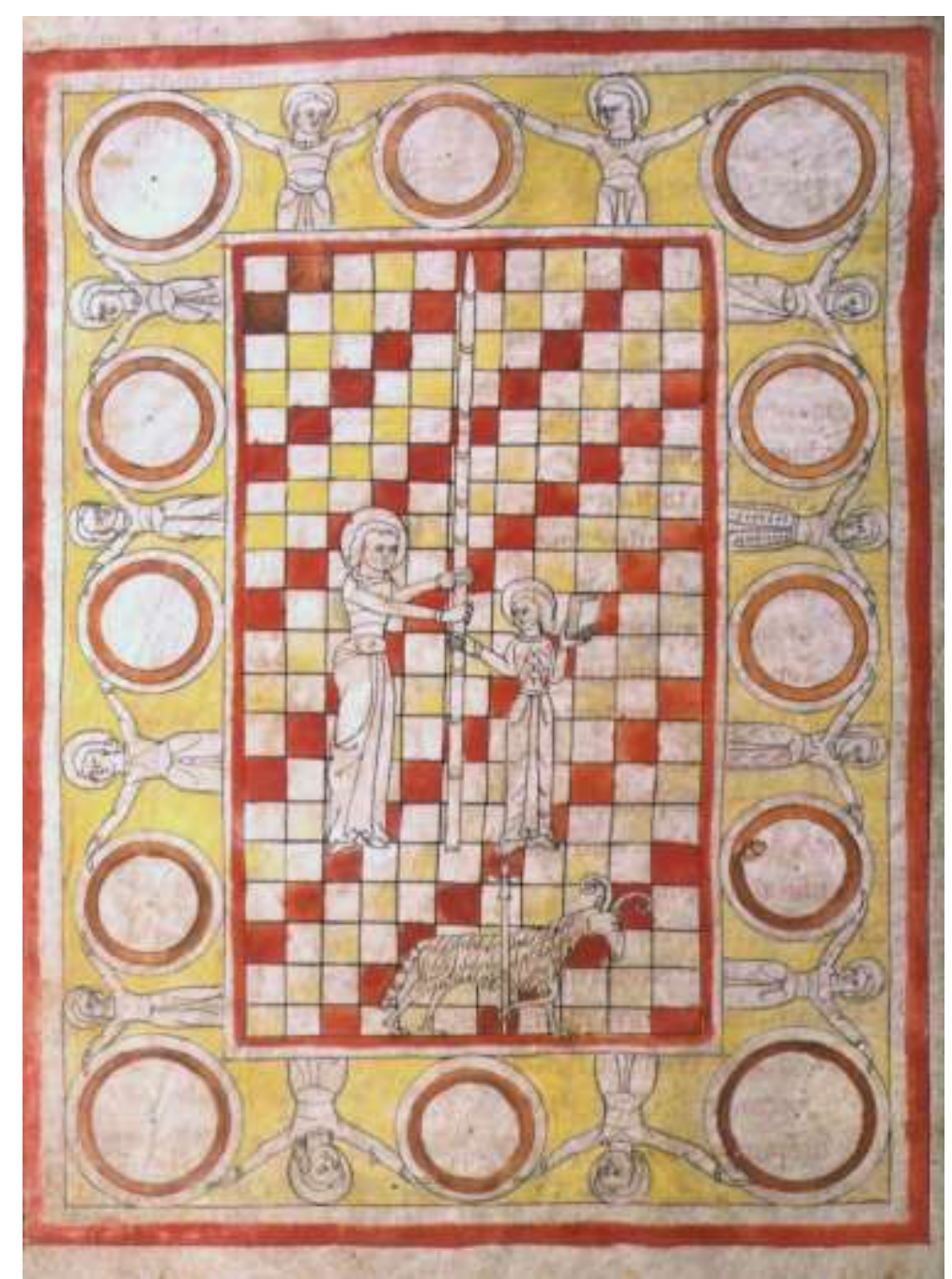

Fig. 20. A Nova Jersalém. Ap. 21, 1-27. BEATO DE LIÉBANA, Commentarium in Apocalypsin; cópia ilustrada do Mosteiro de São Mamede de Lorvão [...], fl. 209 v. 
Ana de Oliveira DiAs, Commentarium in Apocalypsin: o número e a forma geométrica na tradição simbólica das ilustrações do «Beato» de São Mamede de Lorvão

Desta maneira, compreendemos que o número doze denota uma notável riqueza simbólica no seio da espiritualidade cristã, aspecto este espelhado e transmitido, de forma consistente, nos fólios desta cópia. Associado à máxima exaltação do esplendor e glória divina, este número personifica a majestade numérica, o estágio final de êxtase místico e o triunfo do domínio de Deus, manifestando-se como qualificador dos elementos e das estruturas associadas à Igreja vitoriosa e ao início do «Reino dos Céus».

\section{Outros números relevantes no Comentário de Lorvão}

Não obstante as baixas percentagens de ocorrência, contemplamos ainda um conjunto de números nestas ilustrações cuja especificidade merece também nossa atenção. $^{229}$ Números como o cinco, o oito, o dez, o quinze, o dezanove e o setenta, coabitam neste manuscrito num discurso discreto, porém relevante para a confirmação da intencionalidade e do peso da numerologia neste códice.

Classicamente encarado como o número das primeiras ferramentas espirituais $^{230}$ e da virgindade do espírito, o número cinco cumpre a sua função neste manuscrito apenas duas vezes. Correspondendo à junção entre a realidae tangível e a unidade $(4+1)$, este representa numericamente os peixes da terra (debuxados no fólio 138) e o grupo de almas em glória no fólio 149v. A este associado por triangulação $(3 \times 5)$, o número quinze parece reforçar o simbolismo do primeiro número. Vamos curiosamente encontrá-lo, uma vez mais, filiado à figuração dos peixes no mare vitreum (no fólio 86), tal como ao número de almas que compõem a ilustração do fólio 169 , aspecto este que nos sugere de imediato um padrão relacional entre ambos os números (5 e 15) e os elementos iconográficos que caracterizam.

Por outro lado, apesar de identificado oito vezes ao longo deste códice, a ocorrência do número oito não se traduz suficiente para uma clara compreensão da sua expressão simbólica. Descrito como o número da beatitude, do eterno retorno a Deus, de liberação e de paz ${ }^{231}$ - adventista do início da vida após a Criação - coaduna-se, de igual modo, com a representação piscícola: oito são os peixes nos fólios 175 e 195v. (uma das ilustrações consideradas erróneas na relação texto-imagem). Em ambos os casos, a escolha numérica é livre, deliberada, sem «constrangimentos» da fonte literária bíblica ou das restantes cópias. O número oito encontra-se também presente no fólio $150 \mathrm{v}$, sob a forma de almas (no espaço intermédio) ou no fólio 202v. —as almas dos mártirescujos oito pássaros simbolizam as almas dos decapitados (Ap. 20, 4). Podemos, desde já, intuir que no Comentário de Lorvão estes números - cinco, oito, quinze - corroboram então a noção de santidade e pureza: os peixes como símbolo da natureza de Cristo e das suas almas, nas suas diferentes versões

\footnotetext{
${ }^{229}$ Sublinhamos, contudo, que a manifestação destes números não se revela bastante para a constituição de um padrão simbólico.

${ }^{230}$ Jean-Pierre BRACH, p.48.

${ }^{231}$ IDEM, ibidem, p. 48.
} 
Ana de Oliveira DiAs, Commentarium in Apocalypsin: o número e a forma geométrica na tradição simbólica das ilustrações do «Beato» de São Mamede de Lorvão

(humana e animal), num elogio das virtudes espirituais dos agentes que caracterizam.

Extremamente relevante à luz da «ciência numérica», o número dez $-\mathrm{O}$ grande aglutinador ${ }^{232}$ - , estranhamente não evidencia qualquer exuberância nas ilustrações desta cópia, sendo possível identificamo-lo apenas em dois fólios, em três situações. No primeiro dos casos (fólio 150v) são dez as estrelas no plano superior e dez os condenamos do grande terramoto, no inferior. Dez são também os arcos no fólio 176 - Os sete anjos com as sete taças de ouro- em representação do santuário divino (Ap. 15, 5). Encarnando um sentido sagrado desde as primeiras considerações pitagóricas, o dez constitui o reinício - a segunda mónade - a totalidade dos números da unidade à dezena. A sua ocorrência insipiente não nos permite, no entanto, equacionar qualquer sentido simbólico particular para além da sua clara associação a momentos ou espaços votados à perfeição divina e à amplitude da sua obra. ${ }^{233}$

Quanto ao número dezanove - número que caminha para a conclusão da segunda dezena - encontramo-lo expresso nos fólios 207 e 210, revelando-se através do grupo de almas representadas no plano intermédio (fólio 207) e superior (fólio 210). Em relação a este algarismo, sublinhamos o cuidado prestado pelo ilustrador que, visando cumprir a coerência e sequencialidade entre estas ilustrações, mantém rigorosamente o mesmo número de almas em ambos os fólios: no primeiro, estas aguardam a salvação, enquanto no segundo, resplandecem já no seu júbilo.

Ultimando a nossa análise, o número setenta é evocado numa curiosa ilustração debuxada no fólio 119v. Representando os eleitos de Deus, apuramos que não é de todo inocente a sua escolha para esta composição, constituída apenas por uma sequência de bustos nimbados, divididos por seis bandas cromáticas. Como referiu Jorge da Silva Rocha, o Comentário de Beato consagra uma demorada explicação para o número de eleitos bíblicos, evocando incontornavelmente o número doze, a sua metade (seis) e a sua multiplicação por mil e por si mesmo: cento e quarenta e quatro mil eleitos. A evidente importância do papel da numerologia neste episódio e iluminura, leva-nos portanto a discordar deste autor ao afirmar incompreensível - ou produto do erro ou do esquecimento por parte do ilustrador - o número dos eleitos representados ${ }^{234}$,

${ }^{232}$ Dicti autem decem a Graeca etymologia, eo quod ligent et comiungant infra iacentes numeros. «De acordo com a etimologia grega, o número dez é assim chamado dado que compila e aglutina todos os números que o antecedem» - ISIDORO HISPALENSIS, Etimologías [...], p. 424.

${ }^{233}$ AGOSTINHO DE HIPONA, A Cidade de Deus [...], p. 1392.

${ }^{234}$ «Ce souci de la symbolique du nombre est pourtant contredit par la ligne du milieu et du bas qui ne représentent que onze personnages. Un oubli ou un mauvais contrôle de l'espace semble être à l'origine de l'erreur. L'irrégularité, l'hésitation et l'improvisation sont toujours présentes, ici et là, dans le travail de l'artiste du scriptorium du monastère de Lorvão. (...) Dans la représentation des 144000 élus, le moine artiste essaie de compléter le nombre douze sur chaque rangée en introduisant des visages de profil qui semblent entrer en scène par les côtés. $\mathrm{Si}$, apparemment, il s'agit d'un recours graphique pour ajouter un personnage en plus dans l'exiguité de l'espace restant, la procédure reste inexplicable pour la file du haut et pour la 
Ana de Oliveira DiAs, Commentarium in Apocalypsin: o número e a forma geométrica na tradição simbólica das ilustrações do «Beato» de São Mamede de Lorvão

dado não cumprirem, numa lógica espectável, o total de doze elementos por cada barra cromática. No entanto, ao contrário da interpretação de Silva Rocha, esta circunstância reveste-se, no nosso entendimento, de um carácter perfeitamente intencional. Seria deveras inesperado constatar o descuido ou negligência do executante num fólio de tanta expressividade aritmológica, nomeadamente quando é evidente o conjunto de soluções técnicas — como o debuxo de pequenos perfis nos limites do campo de ilustração- de modo a perfazer o número de bustos pretendido. Nesta perspectiva, apesar desta imagem aludir aos eleitos como imagem das doze tribos, o modelo iconográfico parece antes evocar o número dos setenta anciãos de Israel (Ex 24,1-9; Nm 11, 24-25), ou dos filhos de Jacob, ou seja, um número associado aos descendentes e aos eleitos (Ex 1, 5).

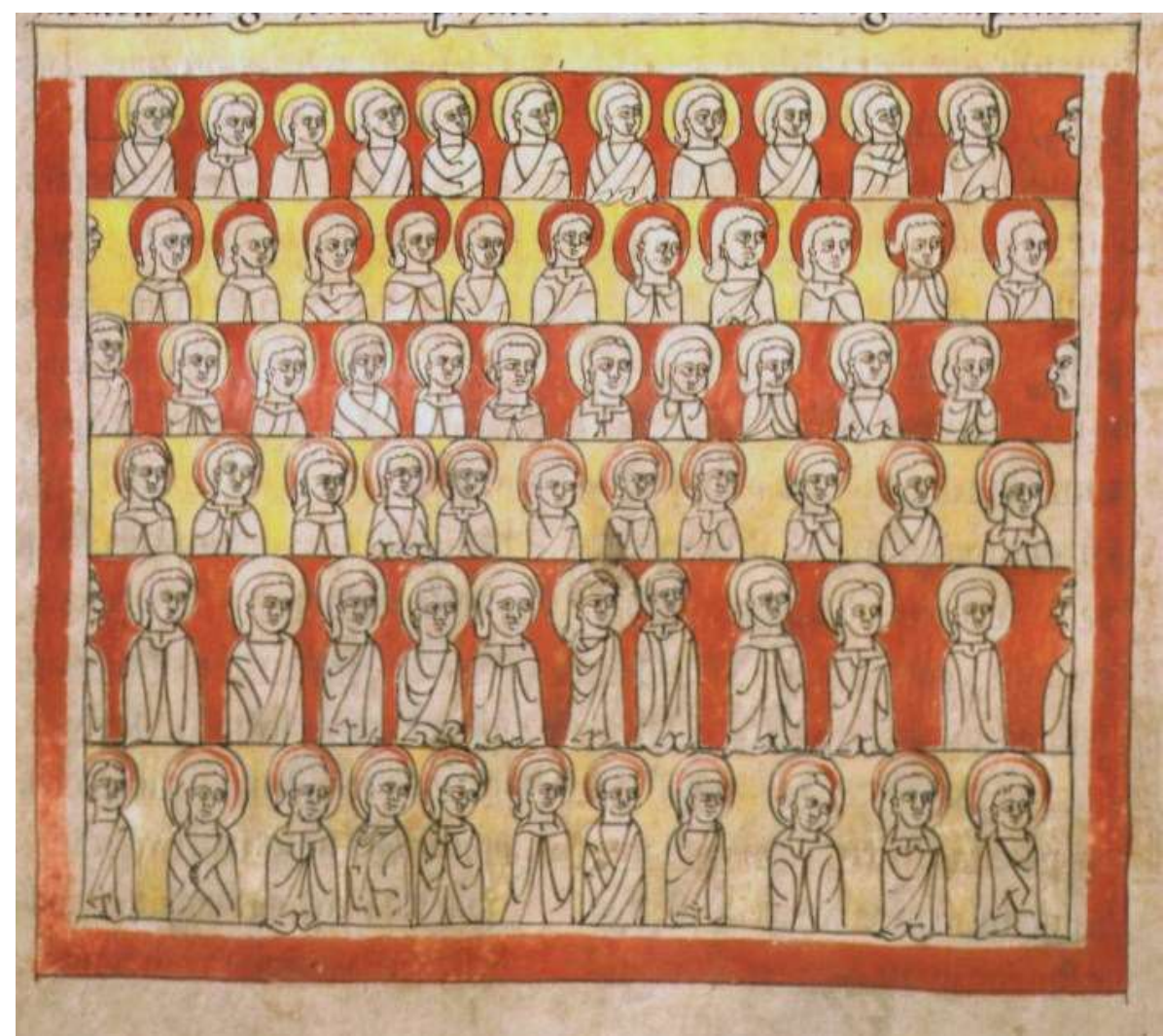

Fig. 21. Os Eleitos do Senhor. Ap. 7, 1-9. BEATO DE LIÉBANA, Commentarium in Apocalypsin, cópia ilustrada do Mosteiro de São Mamede de Lorvão [...], fl. 119 v.

Setenta — número do Antigo Testamento por excelência - constitui assim a multiplicação (no seu estado puro) do sete pelo dez $(7 \times 10=70)$, dois algarismos extremamente relevantes à luz da numerologia clássica e medieval, arquétipos da plenitude e perfeição na relação com o sentido de universalidade. Este resultado simbólico corrobora então a mensagem espiritual deste «Beato»: a representação dos setenta bustos na impossibilidade da figuração dos cento e quarenta e quatro mil eleitos ${ }^{235}$, como testemunhos da magnificência do «Reino dos Céus». Apesar

troisième où l'espace permettrait d'inclure le buste entier d'un douzième personnage.» - Jorge da Silva ROCHA, pp. 284 e 285.

${ }^{235} \mathrm{O}$ número de fiéis $144000=12 \times 1000=12000^{2}$. 
Ana de Oliveira DiAs, Commentarium in Apocalypsin: o número e a forma geométrica na tradição simbólica das ilustrações do «Beato» de São Mamede de Lorvão

da sua singularidade, esta iluminura - e o número que a caracteriza - constitui mais um franco exemplo da intencionalidade e do cuidado com que o programa iconográfico deste modelo foi concebido, recorrendo aos elementos numéricos como auxiliar ao serviço da economia simbólica da obra.

Assim, muito embora diversos dos aspectos conclusivos se encontrarem sucintamente apontados, uma visão de conjunto em torno destes números permite-nos compreender a importância que estes desempenharam na concepção das ilustrações deste manuscrito, revelando fidelidade às suas fontes directas Livro do Apocalipse e Comentário de Beato de Liébana - mas demonstrando, do mesmo modo, um elevado grau de deliberação que necessariamente determinou a diferenciação desta cópia em relação às restantes conhecidas. Como observamos em determinados fólios já citados $(138,139,153 \mathrm{v})$, para além da importância do número no seu sentido lato, confirma-se igualmente uma cuidadosa intenção matemática na concepção destas imagens, perceptível por meio de equações e cálculos «fornecidos» pelas fontes supracitadas e escrupulosamente seguidos (e cumpridos) nas ilustrações desta cópia.

Verificamos ainda que em múltiplas situações - tal como no exemplo do fólio $184 \mathrm{v}$ - , o número assume um papel primordial como veículo transmissor das mensagens espirituais das storiae, evidenciando assim o «Beato» de Lorvão características formais muito mais esquemáticas, estilizadas e vincadamente conceptuais.

Esta análise permitiu-nos também coligir que os números preponderantes neste corpus ilustrativo provam ser os que se prendem, de forma mais estreita, aos desígnios divinos - estruturantes ou finais sobre os planos divino e terreno(como o número três e o quatro), à qualificação e certificação dos códigos maléficos (número seis) ou ao triunfo e à caracterização da Igreja e do «Reino de Deus» (números sete e doze).

Este elemento contrai assim um peso fundamental para a interpretação do programa iconográfico e iconológico desta obra, funcionando como verdadeiro atributo qualificador das diversas personagens, espaços, objectos ou estruturas que compõem estas iluminuras. Afirma-se assim nesta cópia como código espiritual e ritualístico essencial ao imaginário dos criadores deste modelo ilustrativo, denotando igualmente uma clara e importante correspondência com as doutrinas numerológicas agostiniana e isidorina, das quais Beato e os seus continuadores se consideraram descendentes e herdeiros.

\section{A forma geométrica: figuras e tendências geometrizantes nos manuscritos hispânicos}

«Certains historiens ont pensé que les éléments figurés dans les manuscrits mozarabes étaient dispersés arbitrairement à la surface de la page. Telle n'est pas, évidemment notre opinion.». ${ }^{236}$ Assim afirmou Mireille Mentré que, não somente as formas e símbolos representados, como a própria tendência geometrizante dos

${ }^{236}$ Mireille MENTRÉ, pp. 151, 152 e 175 - 176. 
Ana de Oliveira DiAs, Commentarium in Apocalypsin: o número e a forma geométrica na tradição simbólica das ilustrações do «Beato» de São Mamede de Lorvão

enquadramentos nos manuscritos hispânicos alto-medievais, detêm um importante significado para o entendimento dos conteúdos espirituais destas miniaturas. ${ }^{237}$ Partindo, então, da presente premissa, constatamos que a geometria, como produto descendente e auxiliar da «ciência numérica»" ${ }^{238}$, e dividida nos seus quatro pontos fundamentais — plano, extensão numerável, extensão racional e figuras sólidas ${ }^{239}$ - deteve a par do número um papel determinante na concepção e estruturação, quer da gramática decorativa, quer dos programas simbólicos dos manuscritos hispânicos. ${ }^{240}$

Inspirados pelo repto da autora supracitada, e assumindo o peso atribuído pelas doutrinas agostiniana e isidoriana à «ciência da medida e das formas» ${ }^{241}$, procuramos igualmente avaliar se uma mesma preocupação geométrica se verifica e consuma no corpus ilustrativo do Comentário de Lorvão. Nesta perspectiva, dando continuidade ao nosso método de análise, constatamos que tanto do ponto de vista dos enquadramentos, como das próprias figuras geométricas individuais (símbolos ou signos) é possível observar determinados padrões que se manifestam, não apenas como elementos estilísticos, mas como elementos simbólicos ao serviço do programa desta cópia, como analisaremos de seguida.

\subsection{A forma geométrica nas ilustrações do "Beato» de Lorvão: análise quantitativa}

Visando uma análise coerente e sistemática das formas geométricas no «Beato» $[\mathbf{L}]$, incidimos, tal como referido, sobre dois núcleos distintos, separadamente: a) emolduramentos e fundos cromáticos e b) símbolos ou signos geométricos, sendo estes os campos, por excelência, que nos permitem um estudo destas figuras no presente manuscrito. ${ }^{242}$ Assim, uma contabilização

\footnotetext{
${ }^{237}$ IDEM, ibidem, pp. 154 e 155.

${ }^{238}$ ISIDORO HISPALENSIS, Etimologías [...], p. 437.

${ }^{239}$ IDEM, ibidem, p. 436.
}

240 «De quelques analyses que nous avons faites, se dégagent quelques caractères dominants de cette production mozarabe: malgré la tendence à marier l'ornement au symbole, le programme décoratif à la fonction spirituelle, la configuration à la signification (...)»-Mireille MENTRÉ, p. 154. Tal como todo o número tem origem na unidade, o ponto - também este realidade única, total e metafisicamente infinita - dá origem às múltiplas formas geométricas conhecidas, tal como sublinhou Isidoro de Sevilha: Prima autem figura huius artis punctus est, cuius pars nulla est. Secunda linea, praeter latitudinem longitudo (ISIDORO HISPALENSIS, Etimologías [...], p. 438.), tornando-se então clara a comparação que, à imagem da «ciência aritmética», fora estabelecida entre o ponto e a natureza divina. ${ }^{240} \mathrm{O}$ ponto era então tomado como Deus na sua unicidade; a rectitude (ou eixo traçado através desse ponto), era Deus incarnado, a origem da multiplicação de todas as formas. Ainda sobre este assunto veja-se Jacques THOMAS, p. 145.

${ }^{241}$ ISIDORO HISPALENSIS, Etimologías [...], p. 422.

${ }^{242}$ Contudo, tal como refere Mireille Mentré, salientamos, de igual modo, a existência de iluminuras sem qualquer enquadramento ou fundo cromático, debuxadas directamente sobre o pergaminho incolor: «il en existe sans cadres, sans fond de couleur...»-Mireille MENTRÉ, p. 160. 
Ana de Oliveira DiAs, Commentarium in Apocalypsin: o número e a forma geométrica na tradição simbólica das ilustrações do «Beato» de São Mamede de Lorvão

cuidadosa dos diferentes elementos geométricos verificados ao longo dos fólios deste manuscrito, permitiu-nos apurar a existência de uma dinâmica coerente entre os dois grupos que analisamos.

Atentando sobre o primeiro nicho explorado - emolduramentos e fundos cromáticos -, constatamos que na presente cópia são observáveis essencialmente três tipologias formais: quadrilátera (quadrangular e rectangular), circular e emolduramentos com absidíolos em disposição cruciforme (que por questões metodológicas apelidamos de_Ac). ${ }^{243}$ Observamos ainda um conjunto de estruturas estilisticamente variadas que agrupamos num quarto grupo restrito a formas heterogéneas.

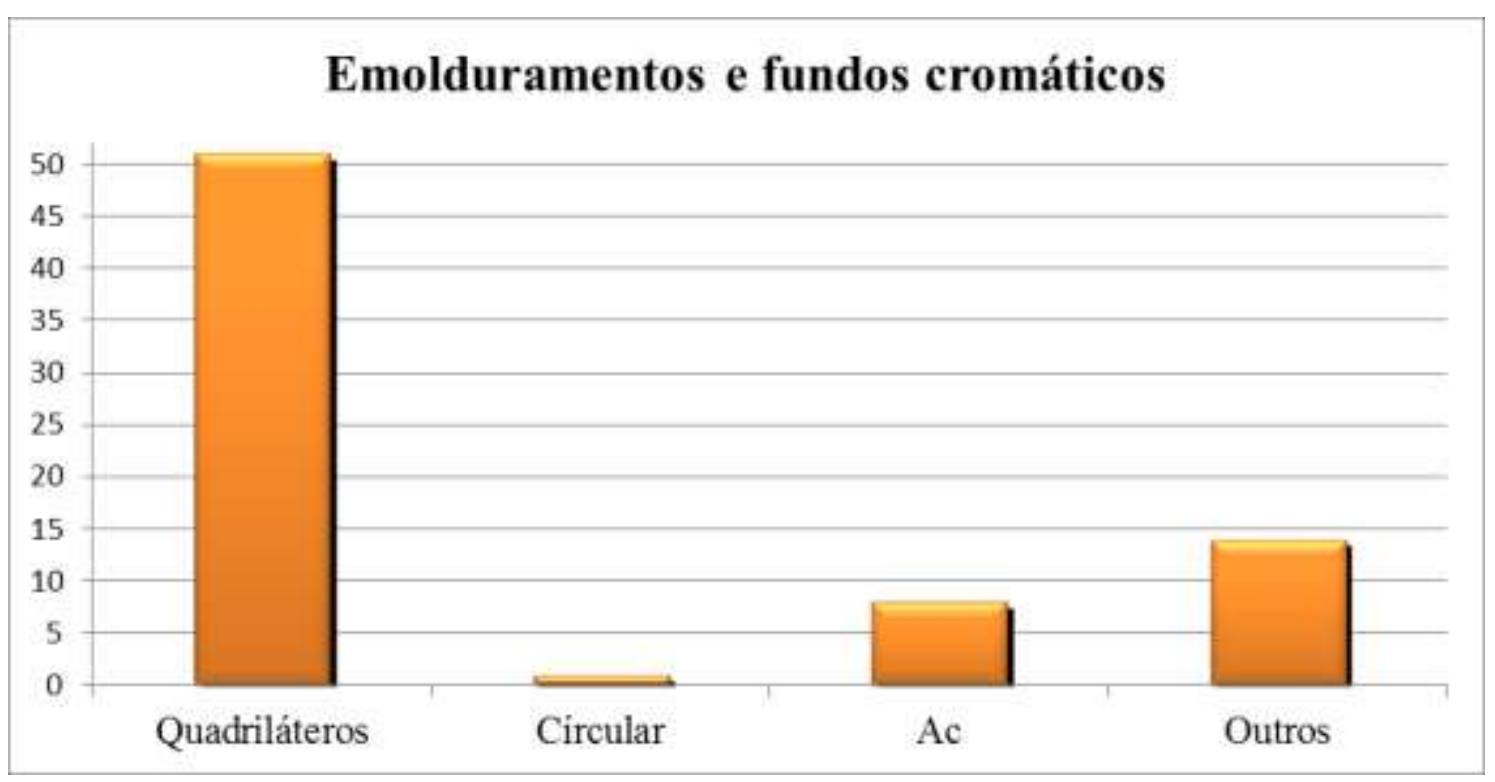

Fig. 22. Formas geométricas nos emolduramentos do Beato de Lorvão.

Num total de sessenta e cinco ilustrações expressivas, testemunhamos então a clara hegemonia das estruturas quadrangulares (51 ocorrências $)^{244}$, seguindo-se os emolduramentos heterogéneos ou «outros» (14), a tipologia Ac (8) e, ultimando a nossa avaliação, o único emolduramento em forma circular representado (1).

\footnotetext{
${ }^{243}$ Cumpre referir que esta tipologia de emolduramentos manifesta-se essencialmente nos primeiros fólios ilustrados, perdendo paulatinamente a sua expressão ao longo do códice. Esta é uma tendência verificada em diversos manuscritos hispânicos do século $\mathrm{X}$, como o caso do próprio «Beato» de Osma [O] - veja-se Anexo iconográfico, Figs. 47 e 48 . Cumpre referir que apelidamos estas estruturas de Ac, em vez de quadrilobadas, visto não cumprirem, efectivamente, este formato.

${ }^{244}$ Para efeitos do presente estudo optámos por considerar a forma quadrangular e rectangular sob a mesma égide, atendendo ao facto de que, no referido período, não se verificavam diferenças de maior quanto à conotação e valência simbólica de ambas as formas geométricas, como podemos constatar em De Figuris Geometriae, nas Etymologiae de Isidoro de Sevilha ISIDORO HISPALENSIS, Etymologiae [...], p. 436. Devemos salientar, porém, a atribuição da máxima perfeição ao quadrilátero cujos lados se apresentassem em medida, rigorosamente, iguais (quadrado).
} 
Ana de Oliveira DiAs, Commentarium in Apocalypsin: o número e a forma geométrica na tradição simbólica das ilustrações do «Beato» de São Mamede de Lorvão

Todavia, ao direccionarmos o nosso olhar para o domínio dos símbolos e signos geométricos, notamos uma total inversão destes resultados. O presente gráfico demonstra que, nesta instância, a forma hegemónica é o círculo (100 ocorrências), seguindo-se os quadriláteros (18) e duas novas formas: o triângulo (7) e o pentágono (2), contemplando este estudo um total de vinte e sete ilustrações expressivas. Estimamos que esta curiosa inversão dos resultados se prende necessariamente às valências alegóricasdas figuras em questão, sugerindo a clara dicotomia entre as duas formas dominantes e fundamentais dos códigos geométricos medievais: o quadrado e o círculo.

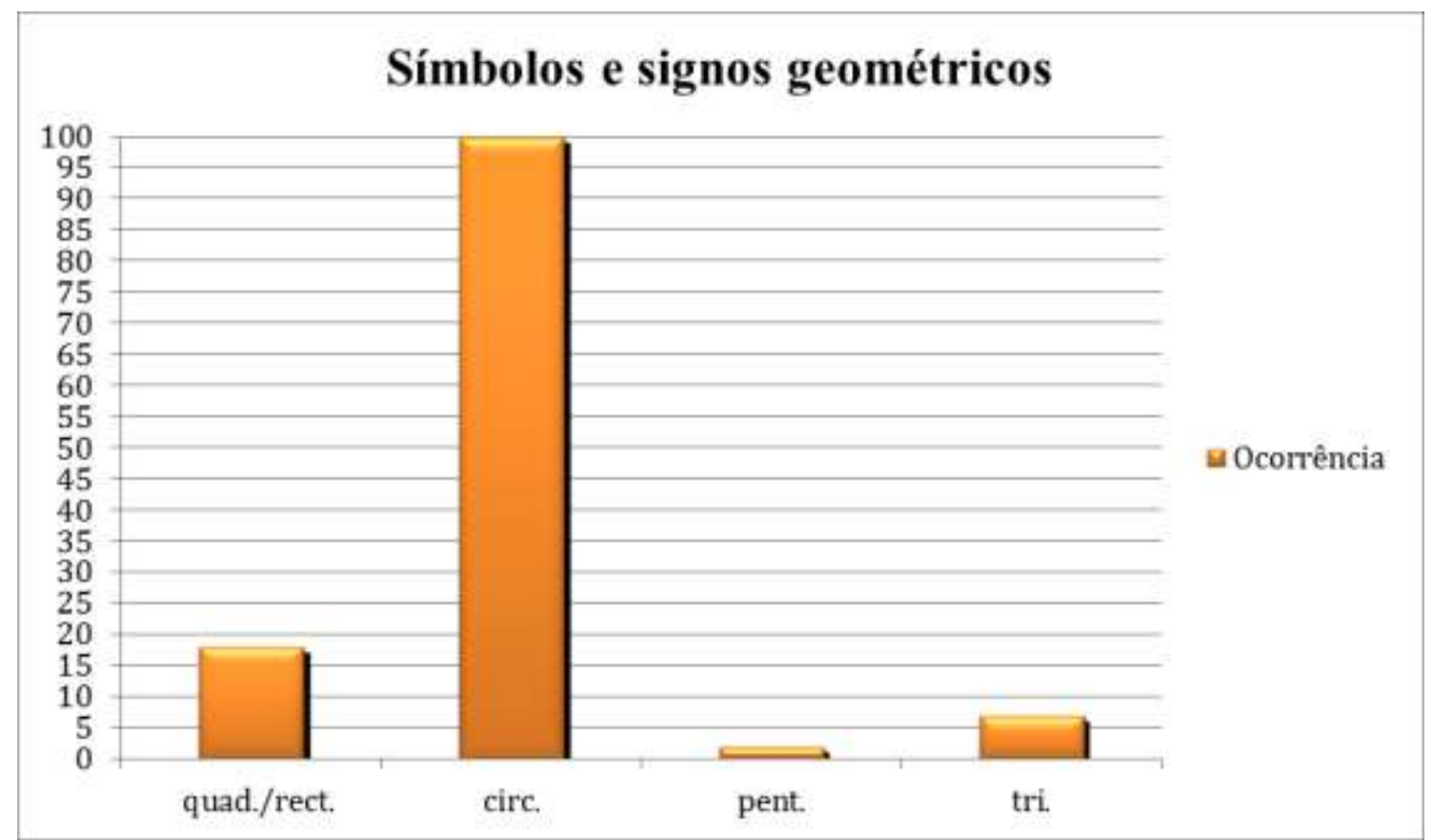

Fig. 23. Símbolos e signos geométricos presentes nas ilustrações do «Beato» de Lorvão

Por conseguinte, estimulados pelas asserções de Mireille Mentré, e mediante os resultados obtidos na nossa pesquisa, foi possível relacionar o códice com a tendência verificada pela autora quanto à linguagem geométrica dos manuscritos hispânicos, verificando que o manuscrito que ora apresentamos se inscreve nesta tipologia, exibindo uma estrutura formal e iconográfica ao serviço da mensagem espiritual.

À imagem do processo de análise encetado em torno dos padrões numéricos, cumpre agora perscrutar o modo como as preocupações de cariz geométrico, em específico, se acomodaram à linguagem estilística e simbólica da cópia laurbanense.

\subsection{A forma geométrica no «Beato» de Lorvão - análise qualitativa}

\section{Quadra}

Forma física correlativa ao número quatro, o quadrado constitui um dos símbolos essenciais da geometria cristã, sendo entendido, nomeadamente por Santo Agostinho, como uma das figuras mais perfeitas, derivada da igualdade das 
Ana de Oliveira DiAs, Commentarium in Apocalypsin: o número e a forma geométrica na tradição simbólica das ilustrações do «Beato» de São Mamede de Lorvão

suas quatro partes constituintes. ${ }^{245}$ Descendente e produto da quaternidade, este assume a mesma natureza matemática e simbólica deste número, funcionando como a sua concretização bidimensional. Desta forma, e uma vez mais, substancia e dá corpo a um plano vincadamente material, evocativo da manifestação divina sobre o plano humano e terrestre. ${ }^{246}$ É precisamente neste sentido que encontramos esta forma — tal como ao rectângulo na sua qualidade de quadrilátero - nas ilustrações dos «Beatos» hispânicos, em particular da cópia que nos ocupa.
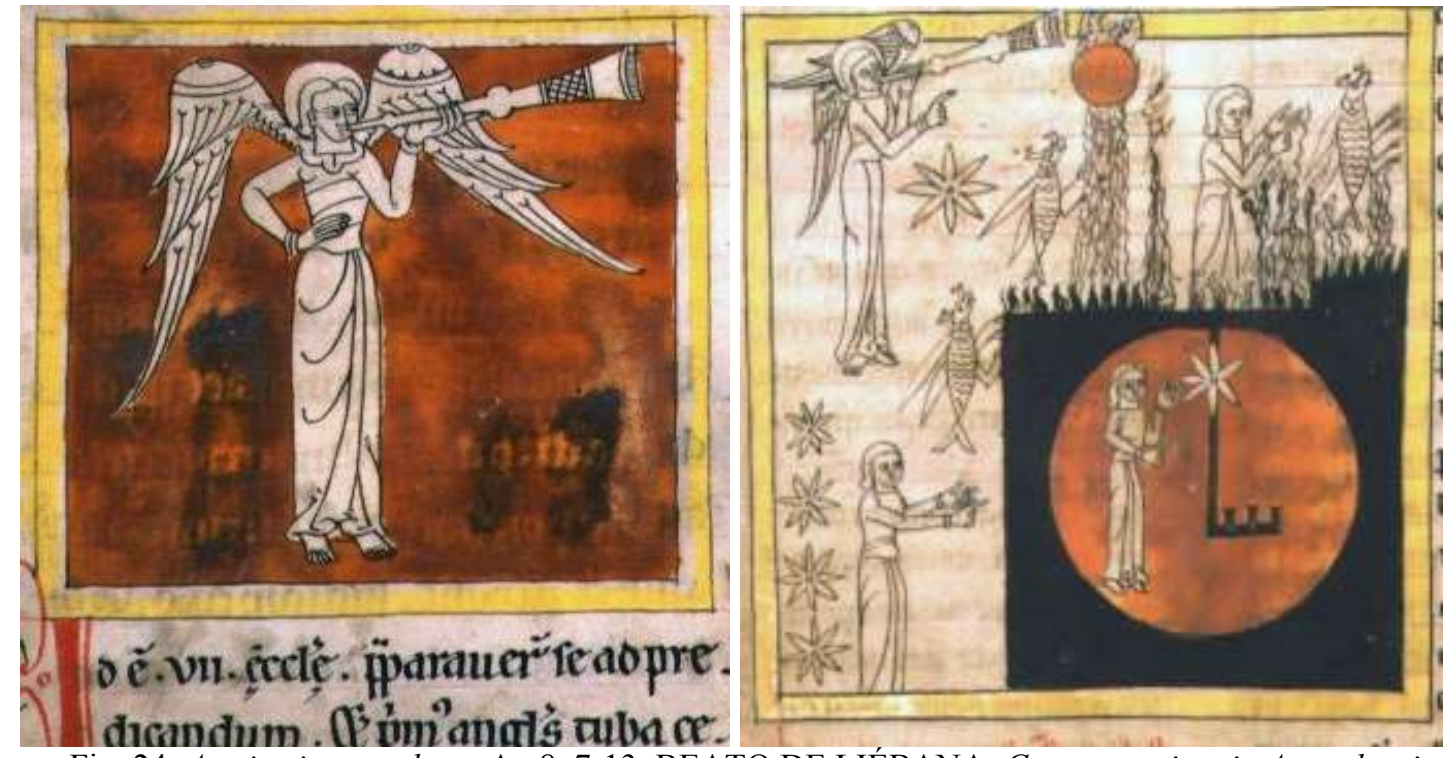

Fig. 24. A primeira trombeta. Ap 8, 7-13. BEATO DE LIÉBANA, Commentarium in Apocalypsin; cópia ilustrada do Mosteiro de São Mamede do Lorvão [...], fl. 136.

Fig. 25. A quinta trombeta. Ap 9, 1-6. BEATO DE LIÉBANA, Commentarium in Apocalypsin; cópia ilustrada do Mosteiro de São Mamede do Lorvão [...], fl. 140 v.

Atentando sobre as considerações da autora supracitada, a recorrência a emolduramentos e fundos cromáticos quadrangulares — tanto nos manuscritos hispânicos alto-medievais (em toda a sua extensão), como nos próprios «Beatos» (em particular) - deve-se possivelmente à necessidade de enquadrar, ilustrar e distinguir campos que, apesar de integrarem agentes celestiais (ou contemplarem planos divinos), representam eventos ou momentos decorrentes num plano temporal. ${ }^{247}$ Assim, através da sondagem das miniaturas laurbanenses, e da sua comparação com exemplares hispânicos (anteriores e coetâneos), foi possível constatar que também esta cópia corrobora a proposta de Mireille Mentré. Como

\footnotetext{
${ }^{245}$ Jacques THOMAS, p. 155; AGOSTINHO DE HIPONA, Obras filosóficas [...], p. 557.

${ }^{246}$ Jean CHEVALIER, Alain GHEERBRANT, “Quadrado”, pp. 548-550.

${ }^{247}$ Mireille MENTRÉ, p. 202. Devemos, porém, salientar que a hegemonia do quadrilátero quanto aos emolduramentos e fundos cromáticos reflecte necessariamente o constrangimento codicológico que, de forma natural, determina a predominância desta estrutura em composições de página inteira. Contudo, à luz dos estudos da autora supracitada e atendendo à verificação de emolduramentos polimórficos neste códice, tais como nos fls. 64, 90, (e à semelhança de outros exemplares hispânicos) concluímos que se confirma uma intencionalidade simbólica latente a estas composições.
} 
Ana de Oliveira DiAs, Commentarium in Apocalypsin: o número e a forma geométrica na tradição simbólica das ilustrações do «Beato» de São Mamede de Lorvão

testemunhos, nomeamos os fólios 118, 136, 138, 138v, 139, 140v, 177 e 184v, ilustradores de acções ou episódios que, apesar de exibirem uma componente interventiva divina, têm lugar sobre um plano vincadamente terrestre, constituindo assim a estrutura quadrilátera — dotada da mesma carga simbólica do número quatro - a caracterizadora da natureza deste plano.

Ao encontro do que acima referimos, também os fólios $86,172 \mathrm{v}, 175,196 \mathrm{v}$, 207 e 210 exibem situações análogas em que, apesar de um plano etéreo se encontrar representado, é sempre concebido numa relação estreita e directa com o plano físico. Muitos dos fólios em que se verifica esta relação são precisamente os que exibem uma estrutura tripartida, sintetizando todos os planos cosmológicos numa única ilustração.

Quanto a símbolos e signos independentes, o quadrado expressa-se de uma forma mais comedida. Testemunhamos a sua ocorrência nos fólios 54, 112, 134, $140 \mathrm{v}, 152,184 \mathrm{v}$ e $209 \mathrm{v}$, visando em todos os casos declarar esse mesmo carácter temporal dos elementos (ou conceitos) que caracteriza. Em ambos os fólios. 112 e 152, verificamos que tanto os altares, como a própria Arca da Aliança, se encontram representados numa forma altamente estilizada, através da simples evocação desta forma. Se notarmos, até mesmo a representação deste último objecto, de reconhecida importância espiritual, é concebido através do desenho de três quadrados concêntricos, rodeados por quatro folhas de acanto, contendo a legenda Arca Testamenti. ${ }^{248}$

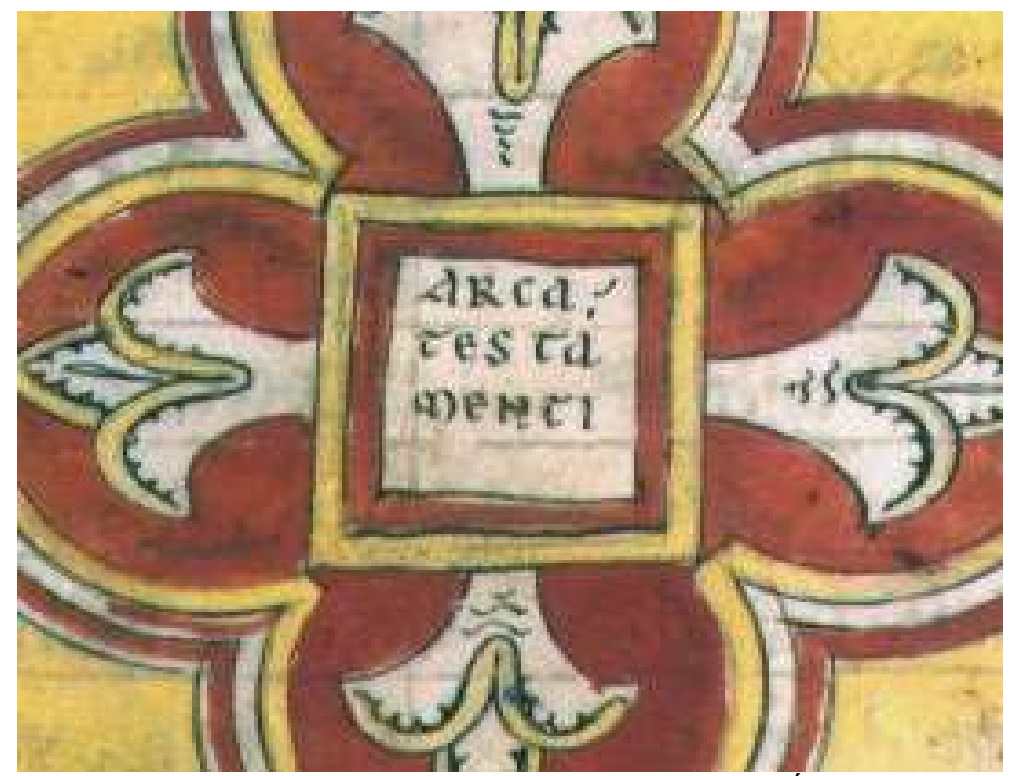

Fig. 26. Arca da Aliança (pormenor). Ap 11, 15-19. BEATO DE LIÉBANA, Commentarium in Apocalypsin; cópia ilustrada do Mosteiro de São Mamede do Lorvão [...], fol. 152.

248 Quanto à representação da Arca Testamenti, podemos verificar um estilo muito mais figurativo e decorativo nos manuscritos das famílias IIa e IIb, em detrimento das cópias da família I - filiadas a uma tradição pictórica mais antiga - cujos elementos se apresentam de forma estilizada em evidência de uma preocupação essencialmente conceptual. Como exemplos salientamos os códices Ms. Vitr. 14-1 (fólio 108), Escorial (fólio 103v.) e de Burgos de Osma (fólio 116v.), bastante próximos da ilustração do manuscrito de Lorvão que reduz este objecto sagrado à sua forma essencial e ao princípio simbólico que pretende transmitir. 
É assim notório o elogio do quadrilátero enquanto forma essencial para a representação de objectos que, apesar de partilharem da natureza divina, se encontram firmados num plano manifestamente sensível. Estes objectos mediadores entre os planos divino e temporal - parecem, então, ser reduzidos às suas formas mais pura e simples, sem qualquer pretensão decorativa, apoiando-se apenas nestas formas que simbolicamente parecem reforçar a sua natureza e função.

Um outro exemplo incontornável é-nos dado no fólio 209v - A Nova Jerusalém - a representação cartográfica da cidade sagrada. ${ }^{249}$ Seguindo o texto da Revelação, uma forma é sugerida: o quadrado «igual no seu comprimento e largura» (Ap 21, 16), indicador da natureza perfeitíssima desta cidade, edificada em plano terrestre. Contudo, ao observarmos a cópia laurbanense constatamos que a ilustração da muralha da grande cidade assume uma forma rectangular, muito provavelmente dada a exigência formal de uma ilustração de página inteira e do constrangimento natural do formato do códice. Devemos, contudo, sublinhar que outros «Beatos trabalharam esta ilustração numa perspectiva mais quadrangular, procurando cumprir com rigor a descrição bíblica.

Assim, a presente composição organiza-se numa estrutura de rectângulos concêntricos, encontrando-se o central preenchido por uma malha quadrangular, onde encontramos o apóstolo com a sua vara de medição, seccionada em doze partes, acompanhado pelo Cordeiro Místico, figuração esta presente na grande maioria das cópias remanescentes.

Desta forma, verificamos a relevância que as estruturas quadrangulares assumem no programa ilustrativo dos «Beatos» hispânicos, em particular da obra que nos ocupa, levando-nos a concluir que a ocorrência mais acentuada destas formas, nas estruturas dos enquadramentos e fundos cromáticos, deve possivelmente a sua razão, por um lado ao evidente formato do códice, mas por outro à procura da demarcação e identificação dos espaços onde decorrem eventos descritos, ou seja, neste caso, no plano do mundo revelado. ${ }^{250}$

\section{Circulus}

Expoente da ideia de perfeição, o círculo — tal como a circunferênciaconstitui uma das formulações geométricas de maior importância na espiritualidade medieva. Participando de algumas das noções comuns ao ponto - unicidade, totalidade indivisibilidade -, esta forma distingue-se, porém, ao assumir um carácter simbólico particular, associado às ideias de consumação da criação, da plenitude e harmonia divina. Neste sentido, o círculo encontra-se relacionado, desde tempos antigos, com essa noção universal de movimento perpétuo, desprovido de início ou fim. É nesta perspectiva que o encontramos associado ao domínio divino e atemporal, numa comparação evidente com a natureza perene e transcendente de Deus e de Cristo $^{251}$. Não nos surpreende

\footnotetext{
${ }^{249}$ Mireille MENTRÉ, p. 196.

${ }^{250}$ Mireille MENTRÉ, p. 202.

${ }^{251}$ IDEM, ibidem, p. 202.
} 
Ana de Oliveira DiAs, Commentarium in Apocalypsin: o número e a forma geométrica na tradição simbólica das ilustrações do «Beato» de São Mamede de Lorvão

assim que as representações do círculo nos fólios do Comentário de Lorvão se coadunem inteiramente com a dimensão divina em toda a sua extensão.

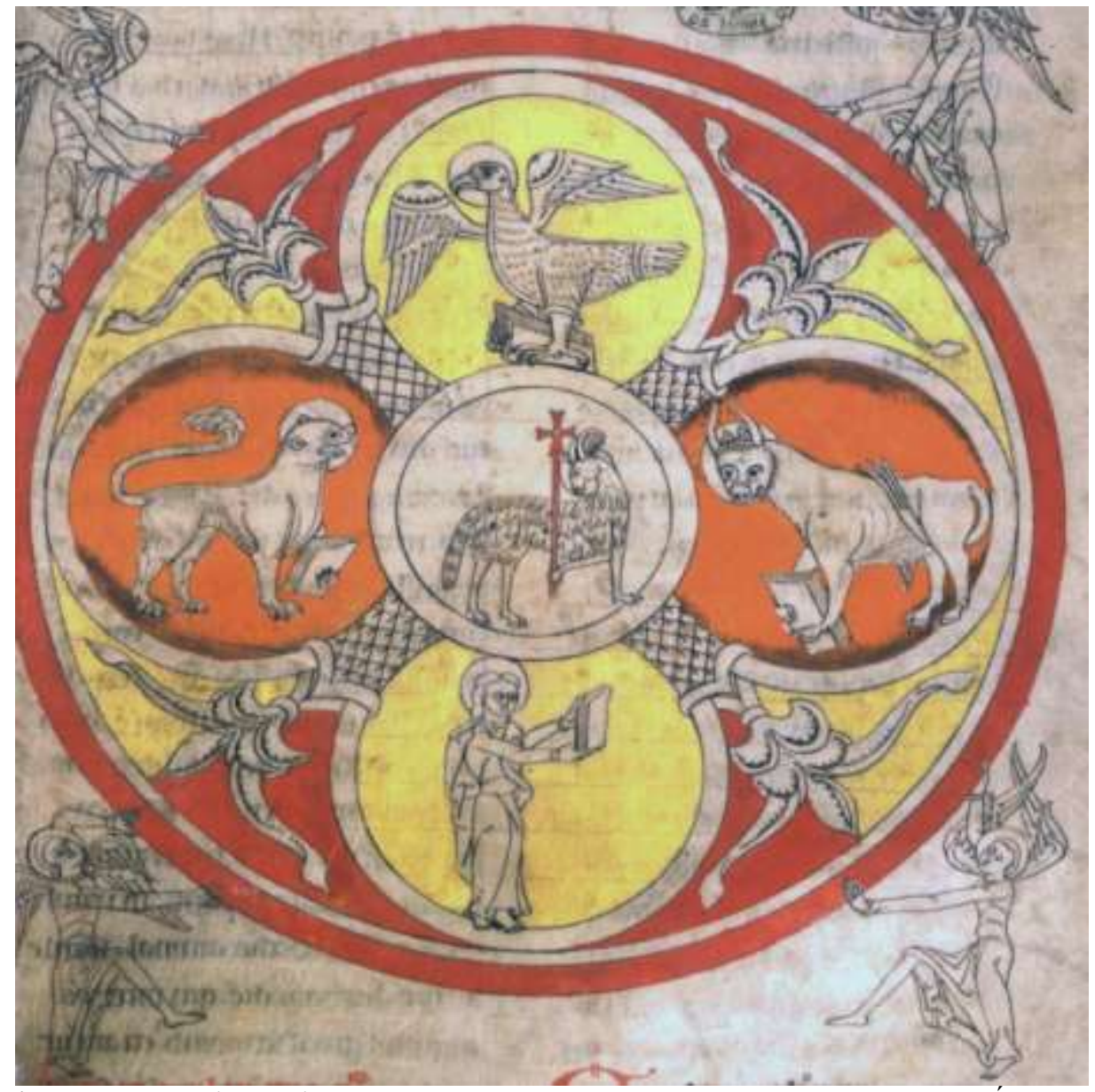

Fig. 27. A visão do Cordeiro e os quatro seres viventes. Ap. 5,6. BEATO DE LIÉBANA

Commentarium in Apocalypsin; cópia ilustrada do Mosteiro de São Mamede do Lorvão [...], fl. 90.

É neste sentido que, uma vez mais, nomeamos os estudos de Mireille Mentré, que na sua análise em torno das formas dos emolduramentos salienta a raridade das estruturas de forma circular nos manuscritos hispânicos, em particular nos «Beatos». No entanto, devemos salientar a excepção do fólio 90 do presente códice que, à semelhança da grande maioria dos exemplares conhecidos ${ }^{252}$, exibe uma estrutura circular enquadrando os quatro seres viventes, acompanhados, no centro da composição, pelo Agnus Dei; o debuxo da figura circular é repetida nove vezes nesta miniatura. ${ }^{253}$ Interpreta então Mentré que as molduras desta tipologia se encontram associadas, sem grandes excepções, a representações exclusivas do Tetramorfo e do Cordeiro místico, na procura de evidenciar o

\footnotetext{
${ }^{252}$ Devemos salientar que os «Beatos» de Burgos de Osma (apesar de muito próximo da cópia laurbanense) e a cópia de Berlim constituem as duas excepções conhecidas a este tipo de representação.

${ }^{253}$ Do ponto de vista metodológico considerámos para a presente contabilização todos os círculos completos (e debuxados com auxílio de compasso), mesmo que apenas para efeito de enquadramento das ilustrações.
} 
Ana de Oliveira DiAs, Commentarium in Apocalypsin: o número e a forma geométrica na tradição simbólica das ilustrações do «Beato» de São Mamede de Lorvão

carácter exclusivamente cósmico e sublime destas personagens, através da sua individualização num espaço qualificador da sua origem divina e transcendente. ${ }^{254}$ Deste modo, encontramo-nos perante a única ilustração que se filia e coaduna com um espaço inteiramente etéreo e atemporal, desprovido de qualquer relação com a dimensão humana e tangível. Podemos então afirmar que a criação da primeira e única iluminura de estrutura circular nestes manuscritos tem possivelmente a intenção de demarcar a um plano visionário e celeste, distinguindo-se das demais ilustrações exactamente pelo campo geométrico em que se insere. Contudo, como vimos, a presença desta forma geométrica no Comentário laurbanense não se restringe a este único exemplo, o círculo ganha pois verdadeira expressão como figura individual neste corpus ilustrativo. Dando continuidade ao princípio simbólico que se associa, podemos então encontrá-lo relacionado com astros (sol e lua), e com elementos portadores, ou conferidores, de luz, todos eles debuxados num estilo perfeitamente estilizado, tal como podemos observar nos fólios. 112, 115, $139 \mathrm{e} 180 \mathrm{v}$.

Constatamos também que o círculo se relaciona com elementos evocativos da presença divina, sendo este princípio verificado nos fólios 196v, 199, 202v, 207, 210 e $217^{255}$, através das representações de halos ou «vias celestes» destinada à manifestação de Deus, ou de Cristo, sobre o plano terrestre. Pretende assim esta solução pictórica demarcar e distinguir — materialmente e espiritualmente- o domínio sacro do profano, o celeste do terrestre, mesmo que inserido numa ilustração do plano tangível. O círculo atesta, portanto, a transcendentalidade do espaço divino em relação às demais personagens representadas.

Focando-nos novamente no extraordinário fólio 134 - Abertura do sétimo selo - este oferece-nos um outro exemplo da evocação da forma circular, encontrando-se neste caso inscrita no quadrado, numa perfeita simbiose entre as duas formas. Esta imagem (exemplo determinante para o que ora defendemos) constitui, portanto, uma construção simbólica de carácter geométrico para a representação episódio da abertura do sétimo selo, sendo concebida no códice laurbanense como uma complexa intersecção de sete circunferências, cujos centros correspondem aos seis pontos divisíveis da circunferência central. ${ }^{256}$ Não negligênciando a legenda septem sigillos sunt (Ap. 8-1), o círculo constitui a figura eleita para a ilustração deste acto divino final: a determinação do silêncio,

254 «Ces peintures circulaires transposent toute la figuration sir le plan du visionnaire. L’espace est transfigure par la celebration fervent dans l'éternité.»-Mireille MENTRÉ, p. 195. Devemos, igualmente, sublinhar a representação de outras estruturas semelhantes noutras cópias, como o caso do fólio $101 \mathrm{v}$ do «Beato» de Osma -Abertura do sétimo selo- que exibe, do mesmo modo, uma estrutura circular, contendo doze estrelas no seu interior. Constitui este fólio a única ilustração deste episódio, cuja natureza geométrica se coaduna com esta forma.

${ }^{255}$ Cumpre referir que diversas cópias ilustradas do Comentário ao Apocalipse recorrem antes a mandorlas ou cartelas ovais ou losangulares para a integração da imagem de Deus ou Cristo. A cópia de Lorvão é, estritamente, circular quanto à apresentação destes elementos. Nomeamos as ilustrações dos «Beatos» de San Millán de Cogolla (fólio 209), de Bugos de Osma (fólio 149) ou mesmo de Navarra (fólio 138), como exemplos dessa diferença formal.

${ }^{256}$ Anexo iconográfico, Fig. 43. 
Ana de Oliveira DiAs, Commentarium in Apocalypsin: o número e a forma geométrica na tradição simbólica das ilustrações do «Beato» de São Mamede de Lorvão

a «suspensão da narração». ${ }^{257}$ Devemos, no entanto, salientar que apesar do códice $[\mathbf{O}]$ exibir igualmente a estrutura circular associada a esta storiae, apenas a cópia portuguesa, entre todos os exemplares, apresenta a forma geométrica por excelência como síntese de um dos episódios narrados.
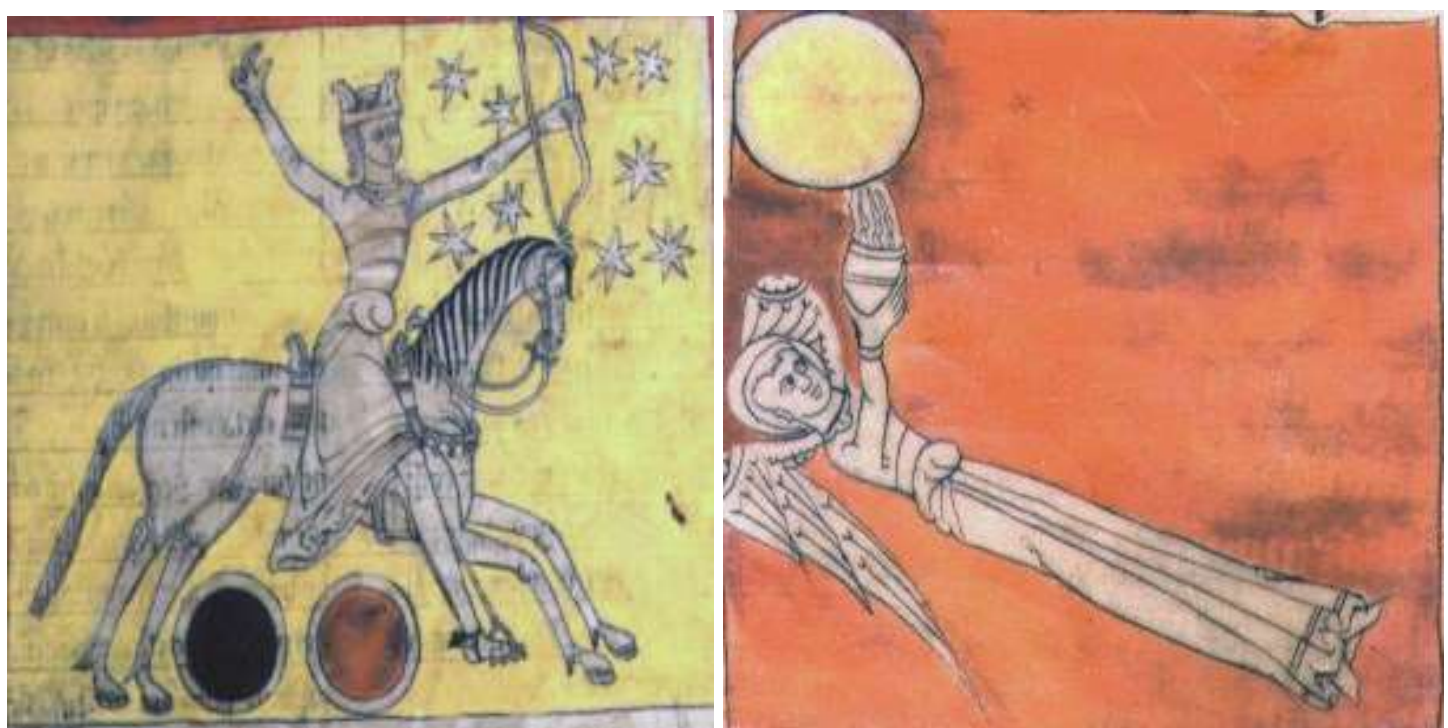

Fig. 28. O grande terramoto. Ap 6, 12-17. BEATO DE LIÉBANA, Commentarium in Apocalypsin; cópia ilustrada do Mosteiro de São Mamede do Lorvão [...], fl. 115.

Fig. 29. Anjo derramando a taça da cólera divina. Ap 16, 2-12. BEATO DE LIÉBANA, Commentarium in Apocalypsin; cópia ilustrada do Mosteiro de São Mamede do Lorvão [...], fl. 180v.

Estes exemplos atestam assim a importância destas formas na concepção das ilustrações do Comentário, demonstrando que existem fortes indícios da utilização da forma circular para a concepção de objectos ou elementos associados ao domínio e à natureza transcendente e divina. Corroborando esta ideia, relembramos ainda os fólios $208 \mathrm{v}$ e 209 , em que as pedras preciosas da Nova Jerusalém são reduzidas a esta forma, como evidência da sua perfeição e condição de atributo espiritual. $\mathrm{O}$ mesmo se verifica na representação desta cidade sagrada (fólio 209v), com figuração completamente geométrica das portas de Jerusalém, reduzidas a três círculos concêntricos apenas.

Depreendemos então a importante carga simbólica que esta figura assume e o modo como é explorada nos fólios do «Beato» laurbanense, numa clara exaltação de todos os elementos do domínio espiritual e celestial — astros, «portadores» de luz, Deus ou Cristo- entes particulares de um universo celestial ou ao seu serviço. O círculo é, portanto, o «pólo essencial» ${ }^{258}$, a forma perfeita, e o código divino por excelência.

\footnotetext{
${ }^{257}$ Jorge da Silva ROCHA, p. 294.

${ }^{258}$ Jacques THOMAS, p. 129.
} 


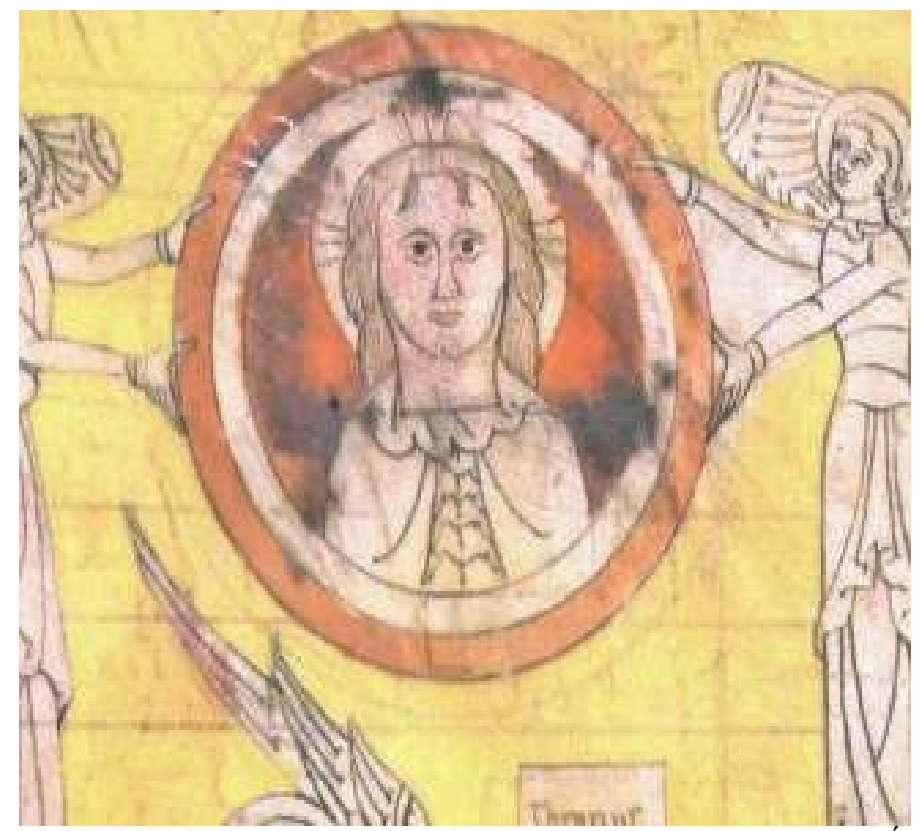

Fig. 30. A despedida de João (pormenor). Ap 22, 6-9. BEATO DE LIÉBANA,

Commentarium in Apocalypsin; cópia ilustrada do Mosteiro de São Mamede do Lorvão [...], fl. 217.

\section{Trigonus}

A forma triangular - correspondente directa e concretização visual do número três - foi entendida, à luz dos princípios simbólicos que ora consideramos, como a expressão geométrica do princípio ${ }^{259}$ e da união entre a ordem divina e humana de Cristo. ${ }^{260}$ Nas suas múltiplas formas, os triângulos — sejam equiláteros, rectângulos, isósceles ou escalenos - assumiram diferentes significados simbólicos aos olhos do homem clássico e medievo, sendo a harmonia, a proporção e o equilíbrio associados ao equilátero (motivados pela igualdade dos seus lados), verificando-se um progressivo afastamento deste arquétipo nos casos dos triângulos rectângulo (divisão do equilátero), isósceles ou escaleno (este último diferente em todos os seus ângulos).

Deste modo, ao longo do presente estudo, verificamos que apesar do seu importante significado, a manifestação desta forma revela-se discreta. Representada apenas sete vezes (somente em três fólios ilustrados), a sua ocorrência insipiente não nos permite, porém, uma profunda e ampla análise das suas valências simbólicas nestas iluminuras.

Observamos, ainda assim, a primeira sugestão no fólio 112 —as almas debaixo do altar -; no segundo registo desta composição, a ligação estabelecida entre o altar rectangular e a figura do apóstolo compõe um triângulo completo,

\footnotetext{
${ }^{259}$ Temos notícia que, mesmo do ponto de vista da análise e estudo das concepções geométricas platónicas, a primeira superfície (e posteriormente sólido) em potência é o triângulo, Jean CHEVALIER, Alain GHEERBRANT, "Triângulo" [...], p. 657.

${ }^{260}$ Jacques THOMAS, p.149. Para além do seu evidente sentido espiritual, o triângulo (na sua relação com o próprio quadrado) deteve um importante lugar (prático e objectivo) na arte medieval - quer na arquitectura, como na pintura ou ilustração - dada a relevante função que o esquadro desempenhou, como instrumento base, no desempenho destes ofícios.
} 
Ana de Oliveira DiAs, Commentarium in Apocalypsin: o número e a forma geométrica na tradição simbólica das ilustrações do «Beato» de São Mamede de Lorvão

invertido, contendo três símbolos (indecifráveis) no seu interior. ${ }^{261}$ Este é um exemplo em que a forma triangular se encontra efectivamente debuxada, porém, observamo-la também, subliminarmente evocada, em toda a relação entre a imagem do altar e a figuração do apóstolo. Contudo, do ponto de vista interpretativo, este constitui um pormenor inconclusivo, pois apesar das semelhanças estruturais entre esta ilustração e as restantes cópias (até mesmo o fragmento de Silos mais próximo estilisticamente desta iluminura laurbanense), a sugestão triangular não se verifica em nenhum outro manuscrito conhecido, parecendo-nos ser assim uma mera coincidência composicional.

Numa mesma perspectiva, no fólio 150 observamos, uma vez mais, uma discreta alusão a esta forma. A estrutura triangular é aqui sugerida através da disposição de três entidades etéreas. No registo superior, as duas personagens sobre os dois tronos, que exibem o busto de Cristo, propõem uma formação $\operatorname{triangular}^{262}$, possivelmente evocando o sentido de harmonia hierárquica. No entanto, à semelhança do exemplo no fólio 112 , esta poderá ser também uma simples questão compositiva.

Contudo, nos fólios 138 e 193, o triângulo encontra-se representado num sentido distinto e de particular interesse. No primeiro fólio, o incêndio que assola a «terça-parte» da terra é representado por meio de dois triângulos que formam o «coração» da chama. Parece-nos, assim, evidente a deliberada utilização desta forma geométrica (possivelmente ditada por um modelo anterior) em detrimento de ilustrações mais detalhadas e naturalistas do elemento fogo, como podemos observar nos restantes «Beatos». Ao olharmos para o fólio 193, representando a Queda da Babilónia, compreendemos, então, que os quatro triângulos isósceles representados corroboram esta alusão às chamas e ao incêndio da cidade. Assim, a estrutura arquitectónica simboliza a grande Babilónia, onde observamos o anjo num plano celestial (separado da cidade por um grupo de blocos de pedra e quatro ramos de acanto - símbolo da virgindade do espírito) e o restante espaço: «antro de demónios e guarida de espíritos imundos» (Ap 18, 2). Indo ao encontro da própria descrição apocalíptica «Por isso, num só dia cairão sobre ela os flagelos que merecia: morte, luto, fome; e o fogo a destruirá.» (Ap 18, 8), constatamos que os presentes triângulos, à imagem do fólio anteriormente citado, pretendem efectivamente representar as chamas que consomem a grande cidade $^{263}$, constituindo este pormenor apanágio do modelo ilustrativo laurbanense, uma vez que apenas este manuscrito recorre ao triângulo como solução iconográfica para este elemento natural.

Voltando-nos novamente para a Antiguidade, foram as considerações pitagóricas, imortalizadas a posteriori pelos filósofos platónicos, que relacionaram o triângulo com o elemento fogo, dada a semelhança formal entre este elemento e a chama incandescente; comparação esta também atestada por Isidoro de Sevilha nas suas Etymologiae em relação ao sólido correspondente a

\footnotetext{
${ }^{261}$ Anexo iconográfico, Fig. 44.

${ }^{262}$ Anexo iconográfico, Fig. 45.

${ }^{263}$ Jorge da Silva ROCHA, pp. 601 e 602.
} 
esta figura, a pirâmide ${ }^{264}$; por conseguinte, este seria possivelmente um código vigente e familiar de Beato, dos ilustradores seus contemporâneos e, até mesmo, dos seus seguidores, como de resto comprova o presente manuscrito.
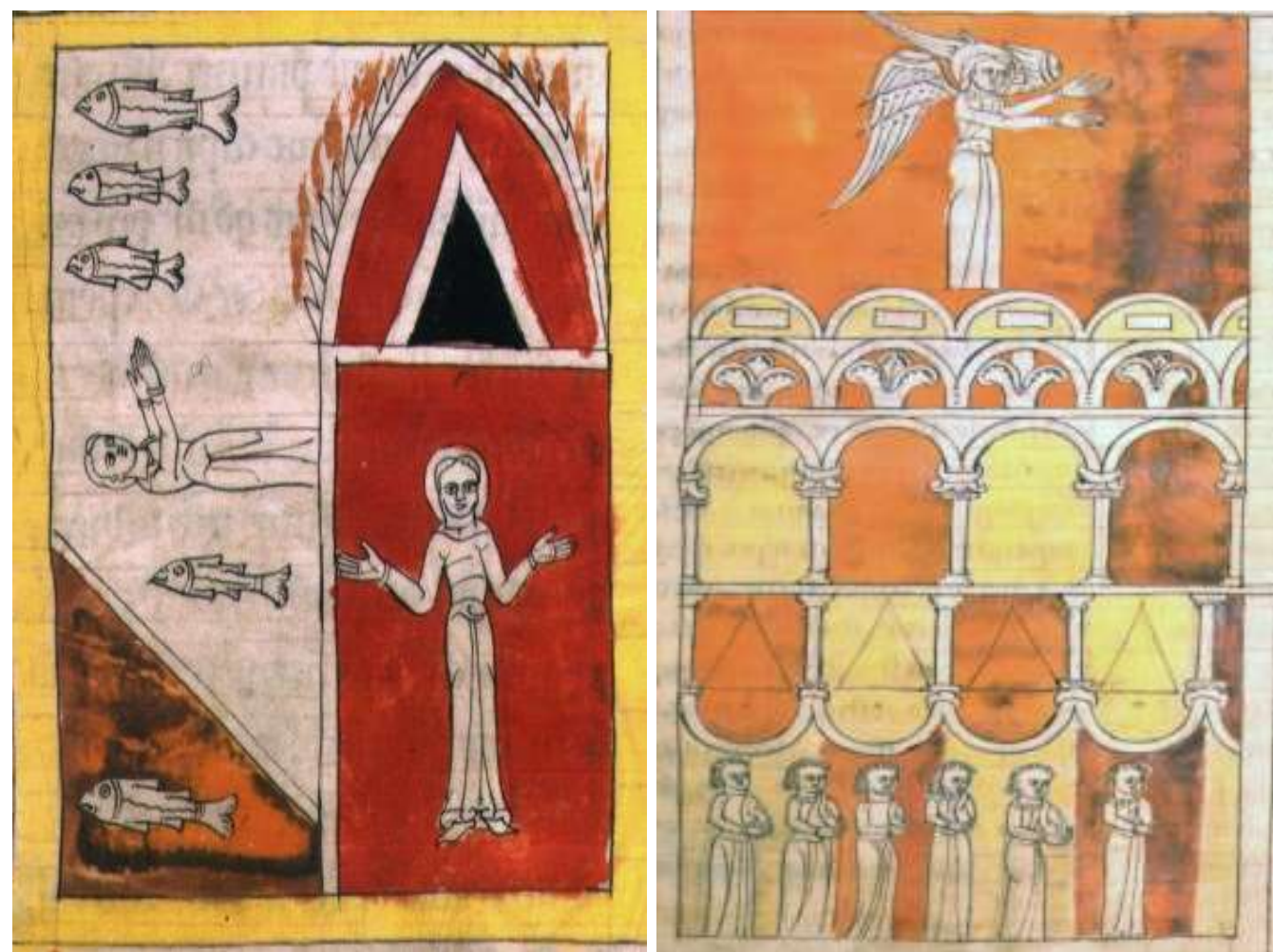

Fig. 31. A primeira e a segunda trombeta. Ap 8, 7-9. BEATO DE LIÉBANA, Commentarium in Apocalypsin; cópia ilustrada do Mosteiro de São Mamede do Lorvão [...], fl. 138.

Fig. 32. A queda da Babilónia. Ap 18, 1-19. BEATO DE LIÉBANA, Commentarium in Apocalypsin; cópia ilustrada do Mosteiro de São Mamede do Lorvão [...], fl. 90.

Concluímos, desta forma, que apesar do baixo índice de ocorrência nestas ilustrações, o triângulo desempenha uma função bastante sui generis, demonstrando a sua associação (e a continuidade) às noções platónicas que estabeleceram a relação entre as figuras geométricas e os elementos naturais (água, fogo, terra, ar), demonstrando, assim, a actualidade dos conceitos matemático-filosóficos clássicos, não somente no período alto-medieval, como mesmo posteriormente.

Apuramos ainda que não se verifica (à partida) a presença de triângulos equiláteros, confirmando que, neste códice, a função simbólica do triângulo se coaduna tendencialmente à conceptualização do elemento natural fogo.

\section{Outras formas geométricas relevantes no Comentário de Lorvão}

Apesar da verificação de três formas dominantes nas ilustrações do Comentário [L] — quadrado, círculo e triângulo- cumpre ressalvar a expressão

\footnotetext{
264 «Pyramis est figura, quae in modum ignis ab amplo in acumen con surgit; ignis enim apud Graecos "pyr" appellatur»-ISIDORO HISPALENSIS, Etymologiae [...], p. 438. « A pirâmide é uma figura que como o fogo de eleva desde a base até terminar em ponta de lança, entre os gregos o fogo é chamado de "pyr".» (tradução nossa).
} 
Ana de Oliveira DiAs, Commentarium in Apocalypsin: o número e a forma geométrica na tradição simbólica das ilustrações do «Beato» de São Mamede de Lorvão

de algumas outras de particular interesse, ocorrentes tanto a nível dos emolduramentos, como das figuras geométricas independentes.

Quanto aos emolduramentos e fundos cromáticos, encontramos o conjunto de estruturas, anteriormente denominadas «Ac», cuja formulação consiste na inclusão de semicírculos trabalhados a compasso (como que absidíolos) numa estrutura quadrilátera, tipologia esta relativamente comum nos manuscritos hispânicos do século X, sendo passível de observar, entre os próprios «Beatos», no exemplar [O] do século XI.

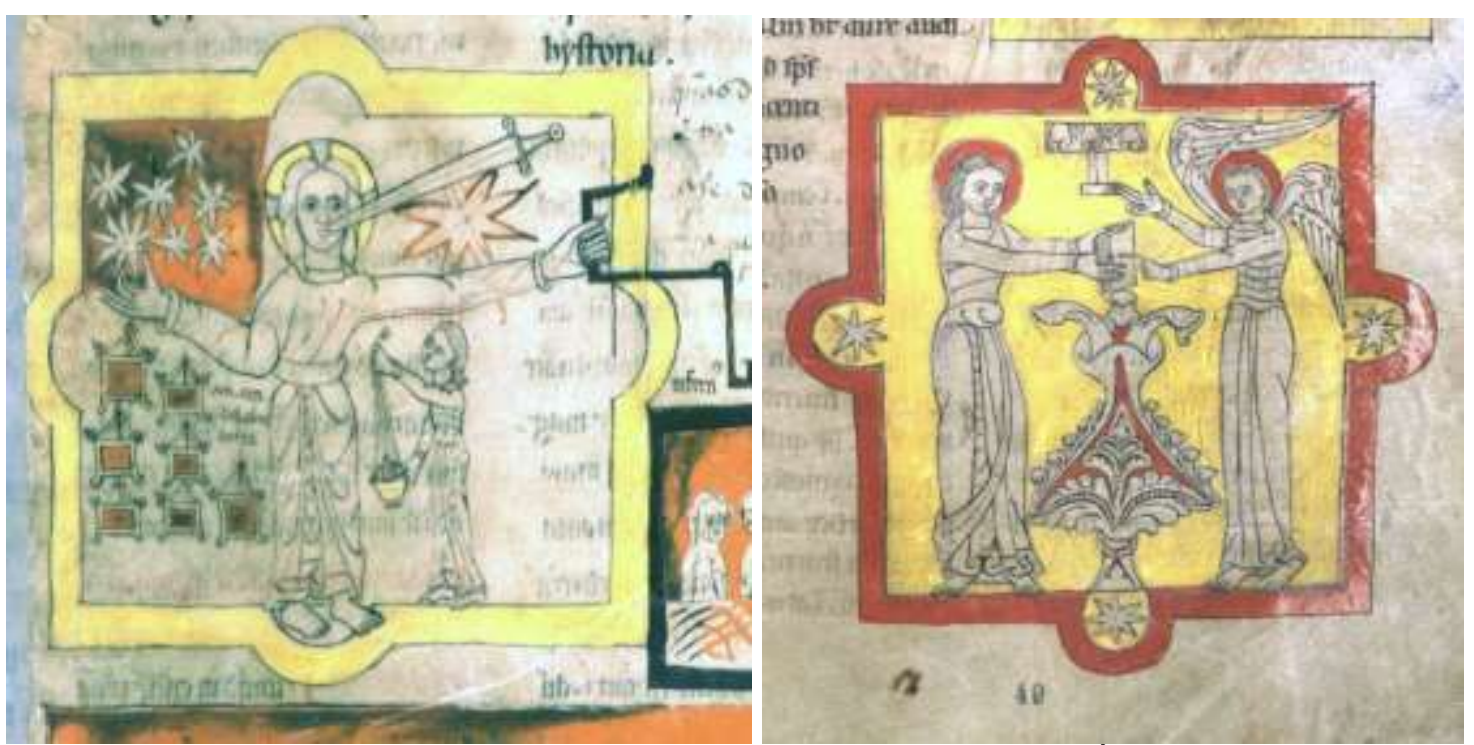

Fig. 33. O mistério das sete estrelas (pormenor). Ap 1, 10-20. BEATO DE LIÉBANA, Commentarium in Apocalypsin; cópia ilustrada do Mosteiro de São Mamede de Lorvão [...], fl. 17.

Fig. 34. Mensagem a Efeso. Ap 2, 1-7. BEATO DE LIÉBANA, Commentarium in Apocalypsin; cópia ilustrada do Mosteiro de São Mamede de Lorvão [...], fl. 49.

Curiosamente, no códice de Lorvão este modelo de enquadramento é somente observado nos primeiros onze fólios ilustrados, não demonstrando continuidade nas restantes iluminuras. Constitui portanto uma tarefa árdua deslindar a existência de um padrão ou significado simbólico a estes associado, sendo, no entanto, aparente a sua relação com cenas de «aparições» ou passagem de testemunho entre um ente celeste e terrestre - porventura pretendendo figurar essa fusão momentânea entre um plano temporal e espiritual, dados os episódios com os quais se relaciona? $\mathrm{Na}$ verdade, a sua expressão revela-se insipiente, não nos proporcionando uma leitura coerente e profunda o suficiente das relações entre este tipo de emolduramento e os episódios iconográficos. Podemos, contudo, encontrarmo-nos perante um simples exercício de estilo, presente no modelo base, desprovido de qualquer sentido alegórico.

Uma outra estrutura relevante - e única no seu género na cópia laurbanense pode ser observada no fólio 64. Representando a Mensagem a Tiatira, a presente iluminura procura contemplar dois episódios distintos: a passagem da mensagem do anjo a João e a representação de Jezabel e seus amantes (Ap 2, 18-28). Para além de ilustrar os dois momentos da storia, demarca assertivamente os diferentes planos de ocorrência destes acontecimentos por meio da sua construção geométrica. Inserida num campo visual quadrangular, vislumbramos 
a grande prostituta e os seus seguidores, acontecimento esse relatado e consumado num plano temporal. Contudo, encimando a «moldura» quadrangular, um arco —evocação da estrutura abobadada - serve de enquadramento para a ilustração da passagem da palavra divina entre anjo e o apóstolo - fundindo ambos os momentos descritos numa única iluminura -, adoptando, porém, a estratégia de distinção da natureza de ambas as representações e dos seus intervenientes.

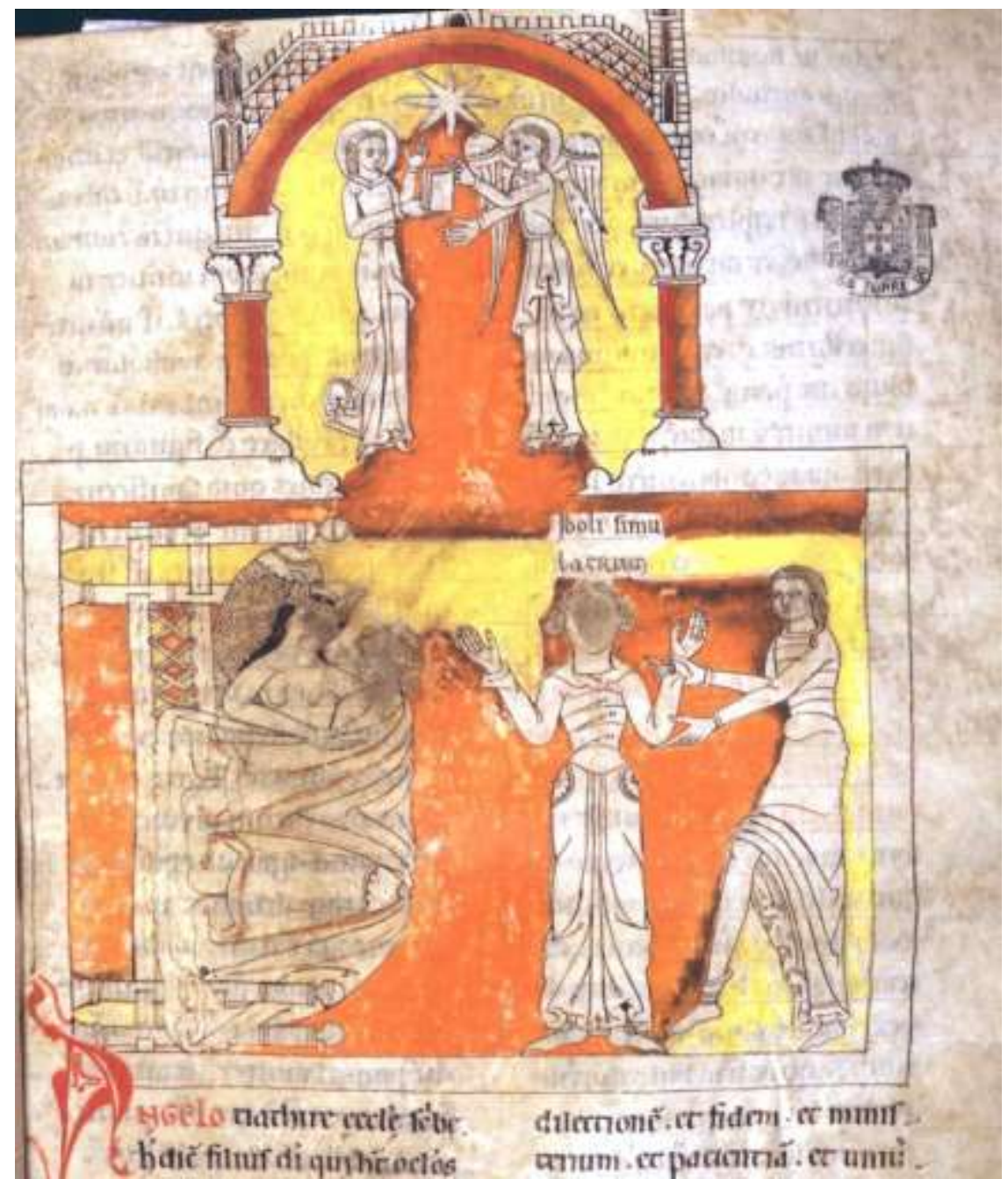

Fig. 35. Mensagem a Tiatira. Ap 2, 18-29. BEATO DE LIÉBANA, Commentarium in Apocalypsin; cópia ilustrada do Mosteiro de São Mamede do Lorvão [...], fl. 64.

Por conseguinte, a fusão entre os enquadramentos quadrangular e semicircular parece demarcar e denunciar essas mesmas diferenças. Inseridos no emolduramento quadrilátero, observamos os acontecimentos relacionados com um plano físico e humano enquanto, por seu lado, o arco enquadra os agentes e o processo da mediação divina, à semelhança do que cremos constatar nos emolduramentos de tipo Ac (porém, neste caso, evidenciando uma estrutura mais descritiva e figurativa por oposição às composições verdadeiramente sintéticas que verificamos associadas e emolduramentos desta tipologia).

Assim, tal como o cruzeiro da igreja medieval — que se eleva e concluí na grande abóbada - esta estrutura parece corresponder e evocar, de certo modo, a 
Ana de Oliveira DiAs, Commentarium in Apocalypsin: o número e a forma geométrica na tradição simbólica das ilustrações do «Beato» de São Mamede de Lorvão

essa mesma equação: a relação distinta, mas complementar, entre quadrado e o círculo, entre o domínio temporal e o espiritual, constituindo o arco abobadado a materialização simbólica deste processo.

Quanto aos símbolos e signos geométricos, encontramos no fólio $120-A$ adoração do Cordeiro - os dois únicos pentágonos presentes neste códice. Esta representação atípica, surge unicamente como nicho para a figuração do Agnus $D e i$, da cruz e das duas figuras que a sustentam. Na presente imagem, o pentágono tem como função o notório destacamento e «mise-en-scène» da imagem do Cordeiro Místico em relação aos demais representados, numa evidente procura da exaltação e demarcação espacial desta personagem (evidenciado até pelo pigmento aplicado sobre esse fundo). O pentágono foi entendido, lato sensu, como forma da harmonia universal no domínio dos planos - encontrando-se na base da proportio divina ${ }^{265}$ - e, deste modo, símbolo da sublimação etérea e das ferramentas espirituais, à semelhança do número que the é correspondente, o número cinco. Dada a percentagem igualmente baixa de representação desta figura geométrica, não podemos então determinar com segurança a existência de uma função simbólica a esta associada na presente cópia, para além da irrevogável ligação ao ente divino, como observamos nos fólios supracitados.

Merece ainda a nossa atenção o fólio $140 \mathrm{v}-A$ quinta trombeta - ao exibir um interessante debuxo geométrico onde, em conformidade com o fólio 134, repete o princípio da inserção do círculo no quadrado, na representação do abismo - governado pelo anjo Apolion (Ap. 9, 11) - trespassado pelos gafanhotos ao toque da quinta trombeta. A forma circular do abismo é semelhante na grande maioria das cópias conhecidas, principalmente da família $\mathrm{II}^{266}$, contudo apenas o «Beato» de Lorvão inscreve o círculo no quadrado. Esta imagem constitui assim mais um exemplo da recorrência à forma geométrica para caracterizar a natureza dos espaços representados.

Consideramos, deste modo, que à semelhança do que se verifica com a componente numérica, o Comentário de Lorvão apresenta uma importante estrutura de elementos geométricos ao serviço da criação, leitura e interpretação dos seus códigos simbólicos. Seguindo o modelo tipológico dos manuscritos hispânicos, a recorrência a molduras e fundos geométricos cumpre a tendência advogada por Mireille Mentré, de uma intencionalidade latente aos emolduramentos que, na grande maioria dos casos, correspondem a formas geométricas simples, alternantes, essencialmente, entre o quadrado e círculo. ${ }^{267}$ Nesta perspectiva, foi possível um enquadramento da cópia laurbanense nestes parâmetros de análise, constatando que a recorrência aos emolduramentos quadriláteros pretende declarar a qualidade do espaço terrestre onde as storiae têm acção. Constitui excepção o fólio 90, única evocação de um espaço

\footnotetext{
${ }^{265}$ Sobre a ideia de Proportio Divina veja-se Jacques THOMAS, pp. 163-171.

${ }^{266}$ Sobre este assunto veja-se Jorge da Silva ROCHA, p. 344.

${ }^{267}$ Mireille MENTRÉ, p. 202.
} 
Ana de Oliveira DiAs, Commentarium in Apocalypsin: o número e a forma geométrica na tradição simbólica das ilustrações do «Beato» de São Mamede de Lorvão

puramente transcendente e celestial, que deste modo exibe um emolduramento circular.

Quanto às figuras geométricas avulsas integradas nestas iluminuras, foi igualmente possível apurar a expressividade da sua função na composição dos episódios relatados. Neste ponto de análise (contrariamente ao anterior) a hegemonia da forma circular é evidente, facto que se relaciona, estreitamente (e por inversão) com o domínio do quadrilátero do ponto de vista dos emolduramentos e fundos. Como tratamos, o círculo surge como atributo espiritual e como síntoma da presença divina ou celestial sobre o plano terrestre e humano.

Vislumbramos ainda a curiosa recorrência às formas geométricas para a evocação de conceitos ou elementos naturais, como podemos verificar quanto à forma triangular, em que o ilustrador deste modelo pictórico terá recorrido a esta forma para a representação das chamas apocalípticas, reminiscência da geometria platónica e neo-platónica que outrora associou as figuras e os sólidos geométricos aos elementos naturais, característica esta somente verificável no presente exemplar.

É possível então constatar uma maior simplificação das formas deste «Beato» que, uma vez mais, parece assumir um carácter muito mais ascético e conceptual, do que literal ou ilustrativo. ${ }^{268}$

Assim, a Geometria - como extensão formal dos princípios numéricosrevela-se um campo determinante de estudo no Comentário de Lorvão, uma vez que corrobora e sublinha a importância que a numerologia deteve na concepção e transmissão dos conteúdos iconográficos e iconológicos destas ilustrações, tal como nos permite sugerir o enquadramento do presente manuscrito numa tradição figurativa bastante anterior ao seu período de produção, dado o seu evidente comprometimento (sem paralelo entre os restantes «Beatos») e recorrência aos princípios geométricos clássicos para dar corpo aos sinais e mensagens presentes nesta obra.

\footnotetext{
${ }^{268}$ Cumpre igualmente referir que apesar da geometria do códice de Lorvão não se demonstrar, por vezes, precisa e rigorosa, é evidente a recorrência e a importância assumida pelos instrumentos de trabalho do ilustrador que, mais do que meros utensílios práticos, possuíam uma função ritual como ferramentas alegóricas para a concepção do objecto de devoção e exercício ascético. O esquadro, tal como o compasso, constituíram os principais utensílios para a execução do regramento e da própria «mise-en-page», numa interessante relação analógica evocada por Jacques Thomas - entre o esquadro (pólo substancial e símbolo do plano terrestre) e o compasso (pólo essencial, afecto à ordem celestial), num verdadeiro processo de intelectualização dos objectos ao serviço dos copistas e ilustradores para a elaboração destes códices. No Comentário de Lorvão, para além de empiricamente reconhecermos a recorrência a estes meios, é possível observar a sua presença efectiva na concepção destas iluminuras. Diversas linhas e marcas de compasso são ainda hoje visíveis sobre a superfície do velino, levando-nos a constatar a recorrência efectiva a estes instrumentos para a criação das importantes estruturas geométricas deste exemplar. Sobre este assunto veja-se Jacques THOMAS, pp. 129-140.
} 
Ana de Oliveira DiAs, Commentarium in Apocalypsin: o número e a forma geométrica na tradição simbólica das ilustrações do «Beato» de São Mamede de Lorvão

\section{Conclusão}

Ao longo deste percurso de demorada análise das ilustrações do «Beato» de São Mamede de Lorvão, visámos atentar sobre valências simbólicas específicas, intrínsecas à concepção destas iluminuras e, assim, compreender a importância que este sistema de códigos assumiu, quer na elaboração do programa iconográfico, quer necessariamente na recepção e propósitos desta cópia.

Nesta dissertação procurámos então incidir sobre um campo específico e de extrema relevância em toda a extensão do imaginário medievo: o número e, consequentemente, a forma geométrica, como descendente da dita «ciência aritmética» e sua concretização bidimensional. Como referimos, a especulação numérica constituiu uma base fundamental de meditação ontológica, e um suporte para o exercício hermenêutico, sendo porém um terreno interpretativo verdadeiramente complexo, transmissor não somente das verdades divinas ou da mensura mundi, como também de todo um conjunto de importantes sinais quiliásticos, direccionados para os espíritos - conscientes e atentos- na eminência do término do primeiro ciclo terreno.

Ressalvamos, porém, que o estudo e conhecimento destes domínios do pensamento medieval continuam a ser um nicho de análise disperso e exigente, sendo apenas através de um conjunto de parcos documentos artístico-literários (como únicas fontes remanescentes) que nos é permitida uma aproximação ainda que de um modo fragmentrário - destes conceitos e asserções de marcada importância da espiritualidade e imaginário medieval.

Neste sentido, e sob esta égide, procuramos encetar uma análise - nunca antes levada a cabo sobre o corpus dos códices medievais portugueses- atinente neste particular exemplar dos «Beatos» hispânicos (e tesouro bibliográfico nacional), tendo sido o nosso objectivo primeiro substanciar uma metodologia centrada na perscrutação e no reconhecimento da relevância destes níveis intelectuais nos manuscritos e na arte medievais e, consequentemente, dedicarmo-nos à leitura e reconstituição (possível e plausível) dos códigos numéricos, geométricos e da sua significação na economia simbólica da presente cópia. Nesta perspectiva, iniciámos o presente trabalho com a revisitação dos aspectos que consideramos chave para o entendimento dos factos e vicissitudes históricas que estiveram na origem da obra primordial, atribuída a Beato de Liébana. Procurámos, de seguida, atentar sobre os contextos de produção do scriptorium de Lorvão e desta obra em particular, ainda que, por vezes, num esforço infrutífero, considerando que o estudo das possíveis influências e relações radiais com outras casas monásticas (no sentido de apurar eventuais empréstimos, circulação de homens e manuscritos, ou «contaminações» de um imaginário vernacular) continua a constituir um trilho enevoado, cujas contingências temporais trataram de ocultar entre os estratos da memória.

Salientamos, além disso, a importância de uma reflexão em torno dos contextos históricos, sociais e espirituais da comunidade monástica, que poderá ter sido responsável pelo programa — ou pela escolha do modelo - na base deste códice. Assim, através de um exercício afim ao da codicologia quantitativa (componente analítica desta dissertação), procurámos penetrar primeiramente nos 
Ana de Oliveira DiAs, Commentarium in Apocalypsin: o número e a forma geométrica na tradição simbólica das ilustrações do «Beato» de São Mamede de Lorvão

padrões numéricos e geométricos que se demonstram sintomáticos ao longo deste manuscrito, na tentativa de deslindar a motivação que se encontra por detrás destas ocorrências, e as suas relações iconográficas. Através deste processo contabilístico, começámos por constatar a hegemonia dos números da primeira dezena - claro indício da continuada relevância deste grupo numérico que, já desde a Antiguidade, era entendido como o «cofre» do conhecimento universal (contido entre a primeira e a segunda mónade) — tal como a predominância das formas geométricas simples e essenciais, como o quadrado, o círculo e o triângulo, numa evidente analogia cénica para com os domínios celeste, terrestre e os arquétipos naturais, evocados nestas iluminuras.

Nesta perspectiva, a componente qualitativa e sintética da nossa análise buscou uma aproximação interpretativa da ligação que se verifica entre estes números e os diferentes episódios figurados, num diligente esforço de reconhecimento da relação entre os códigos numerológicos observados e a sua efectiva função no programa iconográfico e iconológico do manuscrito em questão. Sublinhamos, como paradigma exemplificativo, a constante exaltação do quaternário -número quatro e os quadriláteros-, aspecto que simbolicamente se encontra comprometido, quer na literatura apocalíptica, quer no «Beato» de Lorvão (como em nenhum outro exemplar congénere), com a expressão dos desígnios divinos sobre o plano revelado, corroborando assim a própria essência narrativa do Livro da Revelação e do seu Comentário.

Os resultados da presente análise demonstram, de forma semelhante, uma conexão estreita entre a manifestação aritmológica nesta cópia e as considerações dos Padres da Igreja latina, como Agostinho de Hipona e Isidoro de Sevilha reconhecidos pelos seus incontornáveis exercícios exegéticos e ontológicos com base no número e na «ciência das formas» - cujas obras sabemos terem influído, de forma determinante, na construção do pensamento alto-medieval e, em particular, na concepção do texto original de Beato. Desta forma, através do confronto dos resultados obtidos no presente estudo com as fontes mais próximas e directas do Comentário do monge de Liébana, foi possível concluir que as ilustrações do «Beato» [L] funcionam, ainda que não premeditadamente, como uma clara «mise-en-scéne» e reveneração destes princípios numerológicos. Todavia, a par deste processo, foi necessário um constante exercício comparativo com as restantes cópias remanescentes, de modo a apurar as verdadeiras especificidades do exemplar de Lorvão face aos restantes manuscritos desta tradição.

Começamos assim por constatar a existência de um grau consideravelmente elevado de divergência iconográfica (31\%) face ao cânone ilustrativo geral, influindo este aspecto, necessariamente, na especificidade dos conteúdos imagéticos e simbólicos veiculados neste códice. Incidindo sobre essas primeiras divergências, começamos, desta forma, por reconhecer que mesmo nos códices afectos à família I (do stemma codicum de Peter Klein) — na qual figura o manuscrito laurbanense - não se verifica a mesma relevância ou rigor no cumprimento dos padrões numéricos observados no «Beato» [L], levando-nos a depreender que, mesmo as cópias consideradas seguidoras de uma tradição ilustrativa mais antiga, parecem não apresentar o mesmo comprometimento 
Ana de Oliveira DiAs, Commentarium in Apocalypsin: o número e a forma geométrica na tradição simbólica das ilustrações do «Beato» de São Mamede de Lorvão

simbólico que constatamos neste exemplar. ${ }^{269}$ É justamente nesta discrepância que assenta a originalidade do modelo de Lorvão, que assim acreditamos encontrar-se muito mais centrado e ao serviço dos sentidos morais, exegéticos e ascéticos do ofício divino, do que ao fulgor do fantástico e à exuberância figurativa observada em muitas das cópias do Comentário ao Apocalipse, em particular nas pertencentes às famílias IIa e IIb. Deste modo, é no seu esquematismo primitivo e aparente simplicidade formal que reside a real profundidade destas ilustrações, revelando-se verdadeiramente conceptuais e devocionais. Parece assim evidente o papel que o número desempenhou na construção dos múltiplos códigos espirituais que compõem o programa desta cópia, como podemos observar nas iluminuras presentes nos fólios $119 \mathrm{v}, 134$, $139,153 \mathrm{v}, 184 \mathrm{v}, 193$ ou $209 \mathrm{v}$, que constituem, entre outros, indícios claros do que ora defendemos, e evidenciam essa qualidade de transmissor dos sentidos das storiae que o número assume (declinando a tendência para uma representação descritiva, literal ou de carácter meramente decorativo).

Este facto, associado às ideias advogadas por Peter Klein, da constatação de um primitivismo estilístico incomparável nestas ilustrações ${ }^{270}$, leva-nos, portanto, a crer - com maior conviç̧ão - que a cópia do mosteiro de Lorvão segue efectivamente um cânone figurativo mais antigo e, por conseguinte - dados os seus comprometimentos formais e características alegóricas- possivelmente mais próximo e reminiscente da imagética das primeiras edições ilustradas do Comentário de Beato de Liébana. ${ }^{271}$ Este aspecto pode então ser legitimado pelo notório estilo arcaizante das suas iluminuras, mas também pelos conteúdos simbólicos sem paralelo, que demonstram uma ligação mais imediata e directa às doutrinas aritmológicas agostinianas e isidorianas. Assim, cremos que a função espiritual desta cópia precede irrefutavelmente as qualidades plásticas da ilustração e, deste modo, apesar de constituir um dos exemplares mais tardios na tradição dos «Beatos» hispânicos, pode revelar-se na realidade um «missing link» para a estética e propósitos dos primeiros exemplares do Comentário ilustrado, cujos debuxos se afirmaram certamente como verdadeiros veículos para a meditação activa, eclesiológica e escatológica, e gestos rituais de sublimação divina e de combate.

\footnotetext{
${ }^{269}$ Através da análise e comparação das ilustrações dos restantes manuscritos das famílias I, IIa e $\mathrm{IIb}$, apurámos que o «Beato» [L] demonstra, incontestavelmente, um programa numerológico muito mais vincado do que as restantes cópias remanescentes. Contudo, notamos igualmente traços de uma preocupação numérica em determinados códices, tendo como exemplo: fólio 20v. do «Beato de San Millán, fólio 46 do «Beato» de Fernando I, fólio 23 do «Beato» de Burgos de Osma - referentes à visão das sete estrelas (fl.17v. no «Beato» [L]) ou, ainda, os fólio 117 «Beato» de Valladolid, fólio 153 «Beato» de Girona, fólio 94v. «Beato» de Escorial, fólio 168 «Beato» de Fernando I - referentes ao Toque da quarta trombeta (folio 139 no «Beato» [L]). Estes constituem, apenas, alguns dos casos em que verificamos intenção aritmológica, constatando-se, na sua maioria, em ilustrações cujo símbolo numérico é sugerido pela fonte apocalíptica.

${ }^{270}$ Sobre este assunto veja-se John WILLIAMS, "The illustrated Commentary" [...], p. 53; Peter KLEIN, Beato de Liébana: la ilustración [...], pp. 37 e 41.
}

${ }^{271}$ Peter KLEIN, Beato de Liébana: la ilustración [...], pp. 37 e 41. 
Ana de Oliveira DiAs, Commentarium in Apocalypsin: o número e a forma geométrica na tradição simbólica das ilustrações do «Beato» de São Mamede de Lorvão

Posto isto, a grande questão com que ultimamos o nosso estudo consiste na avaliação da possível intencionalidade ou premeditação, por parte da comunidade monástica laurbanense na escolha deste modelo ilustrativo, ou averiguar se terá apenas constituído uma replicação fortuita, ditada pelo acesso a um exemplar mais antigo que circulava nesta região, ou que se encontrava no armarium de Lorvão neste período. Apesar dos delicados pilares sobre os quais se edifica a biografia dos tempos recuados deste mosteiro, ao reconhecermos as suas raízes assentes sobre a prática de uma vida espiritual de acordo com as tradições do monaquismo ibérico ${ }^{272}$, não nos é estranho um exercício de cópia centrado nas obras de referência da Igreja Hispanica, como sejam os exemplares de Passionarium Hispanicum, Enarrationes in Psalmos de Santo Agostinho ou o próprio Commentarium in Apocalypsin, replicados (estima-se) entre 1176 e 1189 , no scriptorium de Lorvão. ${ }^{273}$ Este aspecto, considerando a cronologia, pode então constituir não somente o reflexo evidente de uma regra firmada no culto e perpetuação dos textos patrísticos, mas essencialmente indício de uma postura de distinção identitária - enquanto comunidade herdeira e depositária de uma longa tradição espiritual - face ao proselitismo do rito reformista, que segundo Aires do Nascimento, foi hostilizado por esta comunidade nos seus últimos anos de resistência cultural.

Não devemos, porém, ignorar a possível influência que as depredações almóadas terão desempenhado na efervescência de uma mentalidade apocalíptica. Temos notícia que o eremítico vale de Lorvão fora também uma região fortemente assolada pela ofensiva muçulmana, podendo este facto encontrar-se na base das motivações para a cópia do Comentário ao Apocalipse $^{274}$, como declaração - ou sinal de alerta para a preparação para a

${ }^{272}$ Como referimos anteriormente neste estudo, estima-se que a comunidade de Lorvão tenha sido devota a um culto de edificação e reveneração dos textos patrísticos, sobre os quais se edificava as regras (plurais) observadas na tradição do monaquismo hispânico - regula mixta. Sobre este assunto veja-se José MATTOSO, "O monaquismo ibérico e Cluny" [...], pp. 55-77.

${ }^{273}$ Sobre este assunto veja-se Aires Augusto do NASCIMENTO, "O mosteiro de Lorvão: A História possível dos seus tempos" [...], pp. 104,107 e 108. Este autor afirma que a extinção definitiva da comunidade masculina de São Mamede de Lorvão, na viragem do século XIII, poderá ter tido origem na animosidade face à introdução da reforma regular operada na Igreja ocidental, que podemos constatar, precisamente, através da cópia de diversas obras comprometidas com a tradição do monaquismo hispânico.

${ }^{274}$ Apesar de não encontrarmos referências quanto aos propósitos exactos quer do texto, quer das
ilustrações do Comentário de Beato de Liébana, verificamos que esta terá sido uma obra cujo
significado se manteve actual durante cerca de cinco séculos. Comentários anteriores, como o
do donatista africano Ticónio, terão sido redigidos na decorrência de períodos hostis e de
perseguição à Igreja, como o caso da guerra entre as facções donatista e ortodoxa da Igreja
africana, experienciado pelo autor supracitado. Tal como o Livro do Apocalipse que se estima
ter sido redigido como declaração das perseguições dos cristãos no Império romano, o
Comentário de Beato de Liébana poderá ter-se assumido, ao longo de séculos de replicação,
como uma obra de apelo e esperança na resistência cristã face à ocupação muçulmana na
Península Ibérica, sendo claros os paralelismos traçáveis entre os agentes apocalípticos e os
grandes símbolos do mundo muçulmano de então - Babilónia: Roma/Córdova, besta
apocalíptica: Império romano/Califado - Henri STIERLIN, p. 81 . Sobre este assunto veja-se 
Ana de Oliveira DiAs, Commentarium in Apocalypsin: o número e a forma geométrica na tradição simbólica das ilustrações do «Beato» de São Mamede de Lorvão

Parusia - da derradeira perseguição e batalha da Cristandade. Cremos, portanto, que a irrupção muçulmana, apesar de não directamente nomeada como razão para replicação desta obra poderá ter sido um elemento intensificador das preocupações escatológicas dos monges de Lorvão; devemos, contudo, ressalvar contudo o avanço positivo da Reconquista nesta cronologia.

Perante esta dupla ameaça - interna (rito romano) e externa (Islão) - a evocação do Apocalipse, por meio do seu Comentário, poderá ter funcionado como paralelo da própria condição social (e espiritual) desta comunidade, e como importante força motriz, e «válvula irradiadora das forças subconscientes» ${ }^{275}$, na qual baseavam as suas crenças salvíficas. Mais do que a cópia de uma obra fundamental da tradição hispânica — reflectora das evidentes preocupações quiliásticas da comunidade - cremos que a recorrência a um cânone ilustrativo, por certo descendente de uma tradição figurativa mais antiga e tradutor de um carácter verdadeiramente ascético e conceptual, poderá advir da necessidade de reveneração e exaltação dos valores morais, espirituais e de memória póstuma desta comunidade ${ }^{276}$, através da cópia de um exemplar mais antigo e mais próximo da estética e comprometimento simbólico que os primeiros exemplares ilustrados do Comentário de Beato de Liébana poderão ter demonstrado. Permanece, no entanto, a questão se este terá constituído um acto intencional por parte desta comunidade, visando a demarcação de uma postura de exaltação dos valores identitários e de resiliência - física e anímica - face à eminente deposição da sua tradição espiritual ou mesmo da própria vida terrena dos monges de Lorvão; esta é, porém, uma questão que permanecerá em aberto.

A visível ênfase colocada num programa simbólico (desta cópia ou do modelo na sua base) assente na analogia numérica poderá ter constituído assim uma opção consciente face à necessidade de um exercício exegético profundo e da preparação para a interpretação dos sinais derradeiros ${ }^{277}$, não nos surpreendendo, deste modo, que os números hegemónicos no programa deste manuscrito sejam exactamente os que se coadunam com comandos e desígnios divinos (número três), com os efeitos finais da vontade de Deus sobre a terra (número quatro),

Bernard MCGINN, "Introduction: John's Apocalypse and the apocalyptic mentality" [...], pp. 3-19; John WILLIAMS, "Purpose and imagery in the Apocalypse Commentary of Beatus of Liébana" [...], pp. 217- 233.

${ }^{275}$ Henri STIERLIN, p. 81.

${ }^{276}$ Mário de Gouveia apurou que, em relação à produção analística, os textos conservados do fundo de Lorvão pautam-se por uma dinâmica de reprodução da memória de um passado distante desta casa religiosa, levando-nos, portanto, a concluir que, tanto a nível da produção documental como literária, a preservação dos princípios e valores da tradição constituíram uma preocupação essencial para estes monges - Mário de GOUVEIA, p. 92.

${ }^{277}$ Mário de Gouveia, na sua dissertação de mestrado, refere brevemente a importância que terá sido concedida ao cálculo e à medição do tempo e dos ciclos terrenos, por parte dos clérigos moçárabes, numa dinâmica de mediação entre o mundo terrestre e celeste. Constatamos assim a relevância efectivamente atribuída à equação e analogia numérica por partes destas comunidades monásticas, nas quais a ordem masculina de Lorvão se inscreve como descendente. Sobre este assunto veja-se Mário de GOUVEIA, p. 92. 
com o reconhecimento dos códigos maléficos (números seis) ou números reflectores da esperança salvífica e triunfo do Reino dos Céus (números sete e doze). Também as formas geométricas - cumprindo os princípios enunciados pelo número- constituíram campos de reflexão em torno das qualidades do espaço espiritual e temporal, funcionando assim todos estes códigos como verdadeiros enunciados para a meditação e contemplação do momento final.

Apesar da complexidade da interpretação destes conceitos e códigos operativos, consideramos que os diversos factores e dados que podemos retirar do nosso primeiro (e humilde) estudo, constituem relevantes pistas para a compreensão, não apenas da importância da investigação nos domínios do imaginário medievo - centrados numa nova reinterpretação da história dos objectos, como ramo extremamente válido para a reconstrução de uma História das mentalidades-, mas essencialmente para a aproximação do modus vivendi $\mathrm{e}$ experiência espiritual desta distante comunidade monástica, e das possíveis razões que conduziram à replicação de um exemplar com as presentes características no mosteiro de São Mamede de Lorvão, nos finais do século XII.

\section{Anexo Iconográfico}

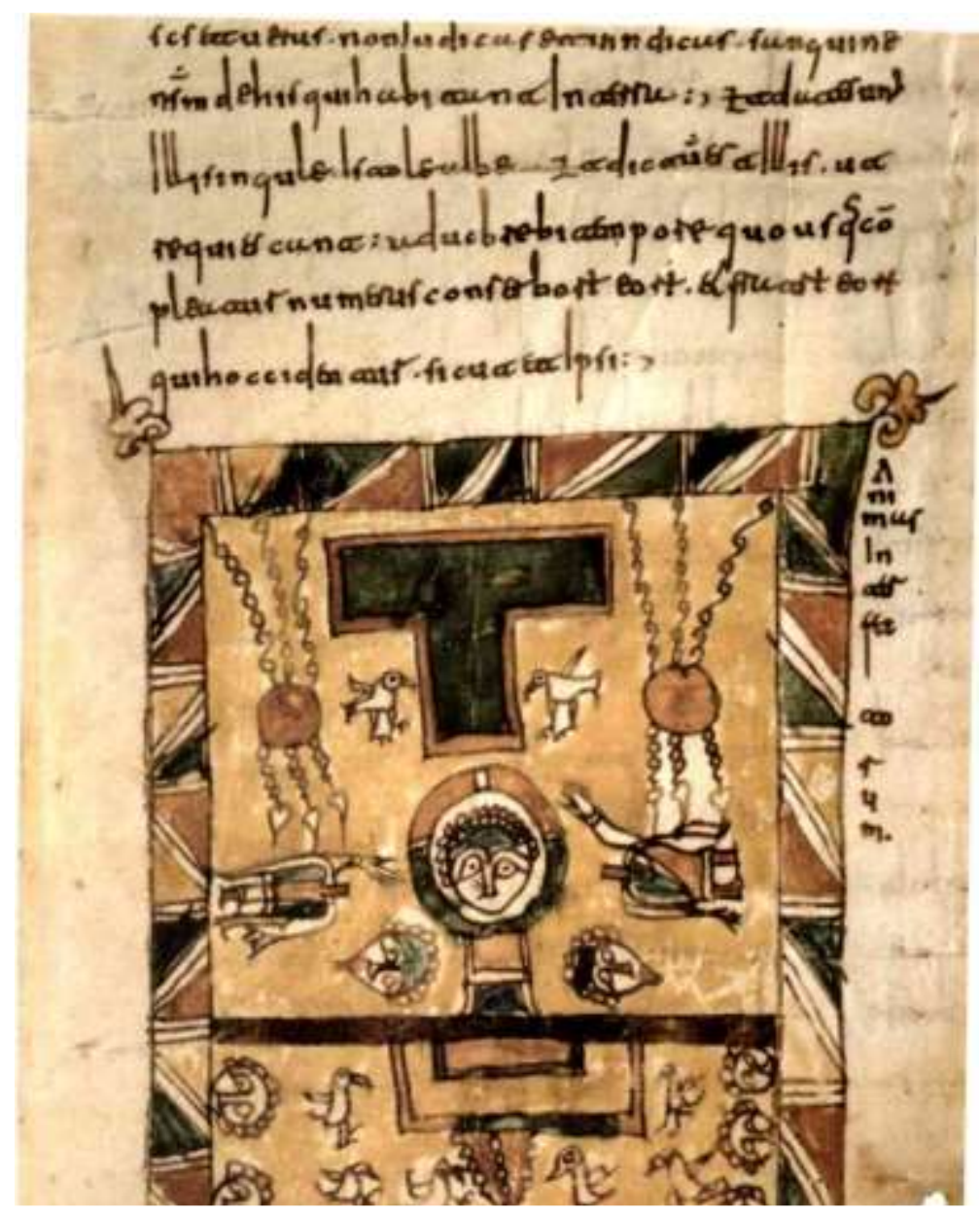

Fig.36. Fragmento [Fc] do Mosteiro de São Domingos de Silos, in http://es.wikipedia.org/wiki/Archivo:SilosBeatusFragmentAltarWithSoulsMartyrs.jpg 
Ana de Oliveira DiAs, Commentarium in Apocalypsin: o número e a forma geométrica na tradição simbólica das ilustrações do «Beato» de São Mamede de Lorvão

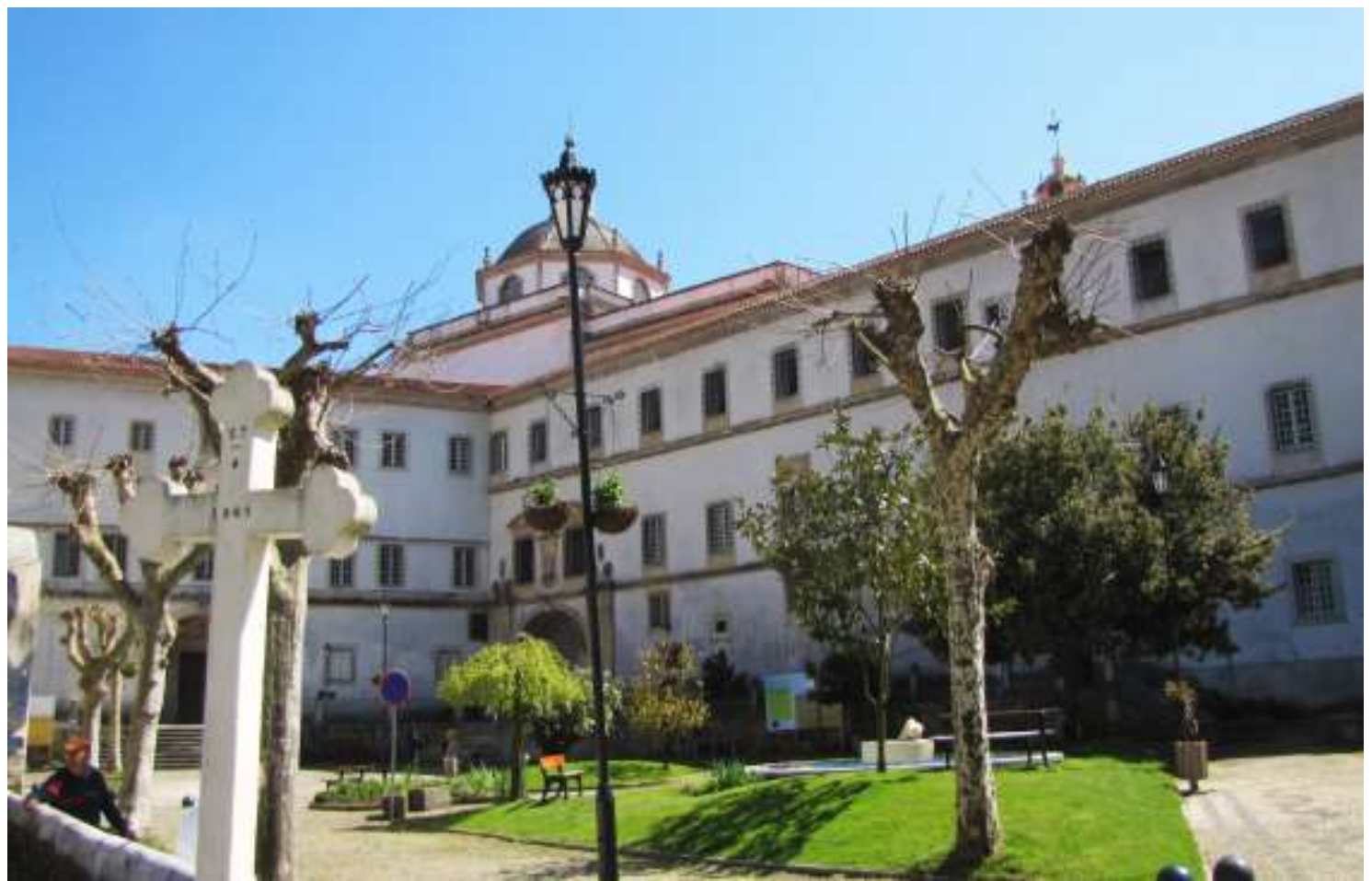

Fig. 37. Mosteiro de Santa Maria de Lorvão. Fotografia Ana de Oliveira Dias, 2011.
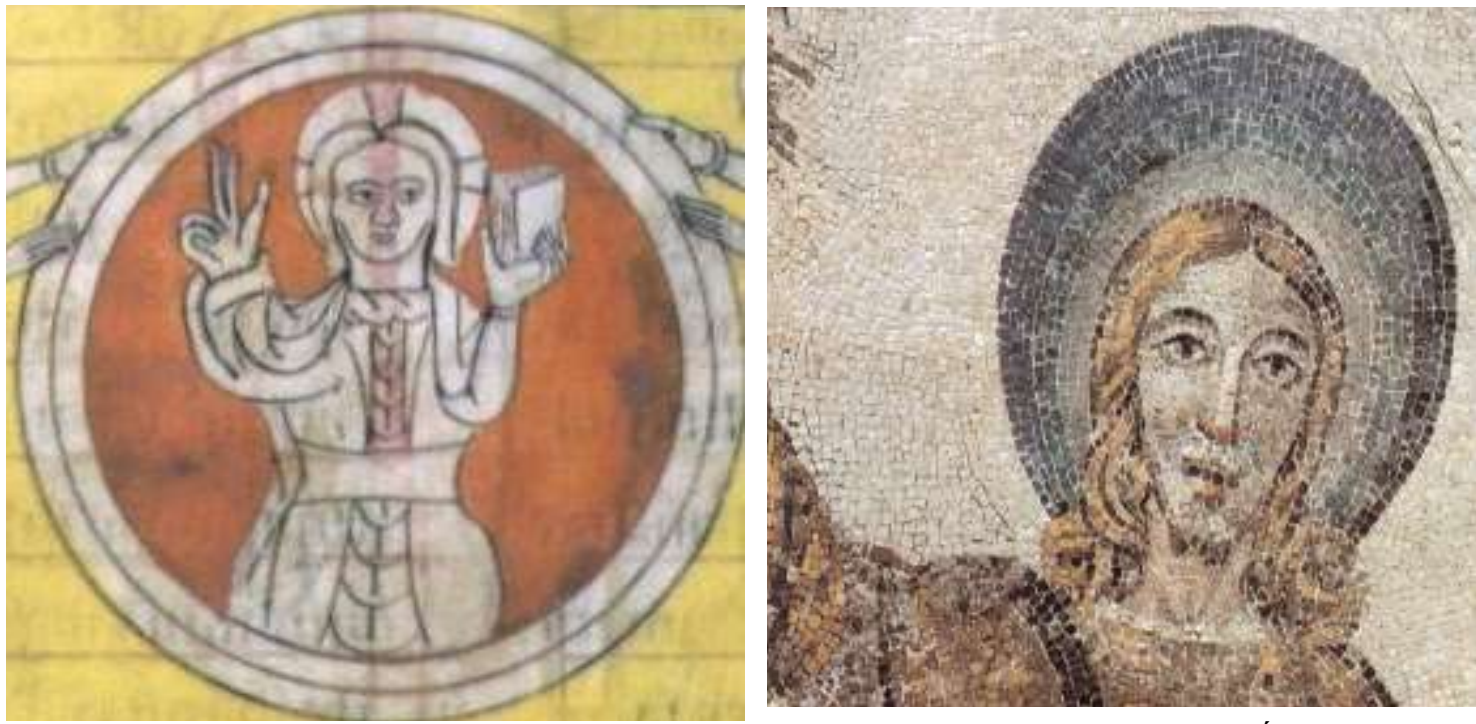

Figs. 38 e 39. A glorificação de Deus (pormenor da ilustração). BEATO DE LIÉBANA,

Commentarium in Apocalypsin; cópia ilustrada do Mosteiro de São Mamede de Lorvão [...], fl. 196v.

(imagem 38); Traditio Legis (pormenor do mosaico), Mausoleu de Santa Constanza, Roma, fotografia de Ana de Oliveira Dias, 2011 (imagem 39). 
Ana de Oliveira DiAs, Commentarium in Apocalypsin: o número e a forma geométrica na tradição simbólica das ilustrações do «Beato» de São Mamede de Lorvão
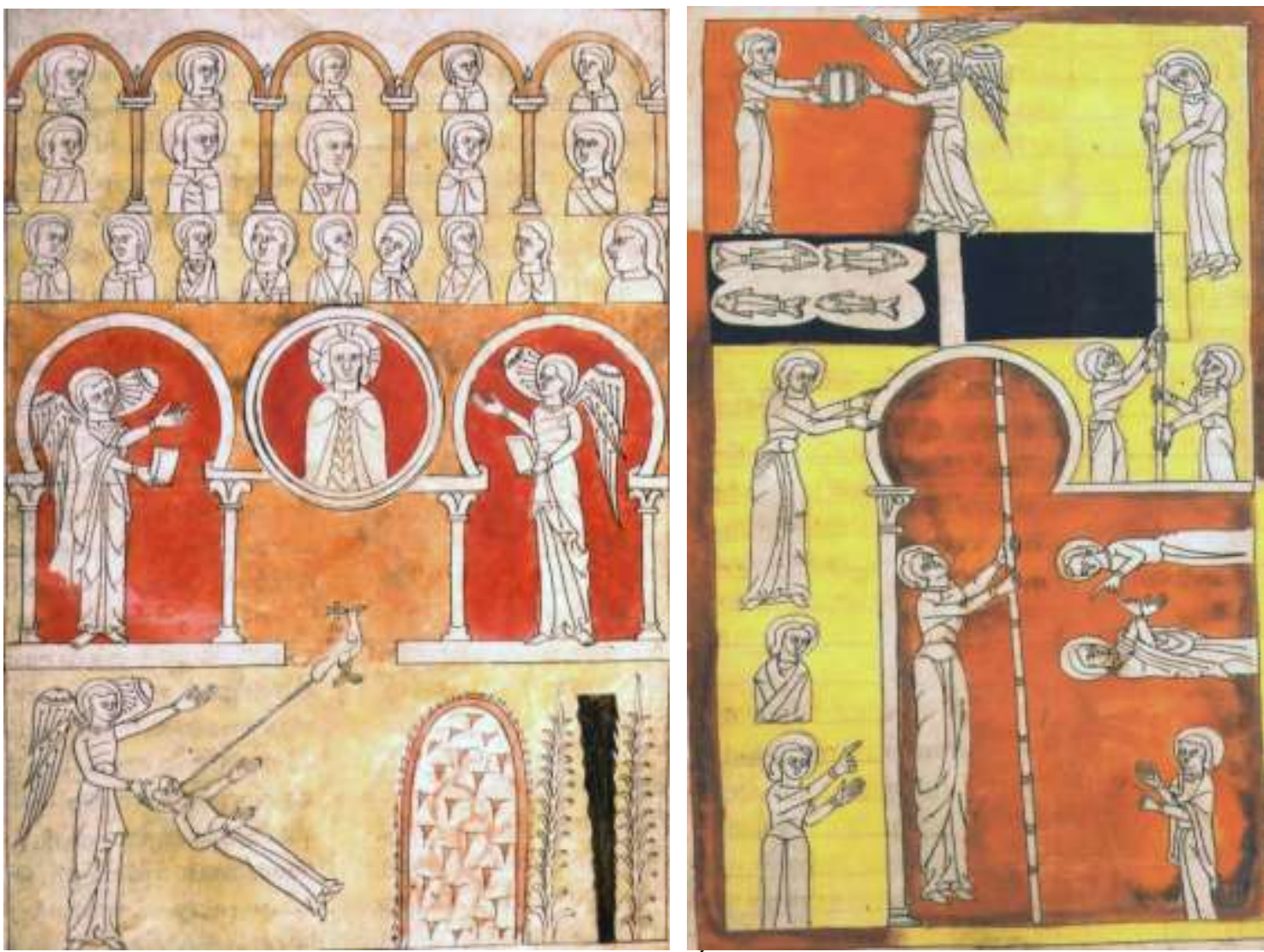

Fig. 40. A água e a árvore da vida. BEATO DE LIÉBANA, Commentarium in Apocalypsin, cópia ilustrada do Mosteiro de São Mamede de Lorvão [...], fl. 210

Fig. 41. A medição do Templo Novo. BEATO DE LIÉBANA, Commentarium in Apocalypsin; cópia ilustrada do Mosteiro de São Mamede de Lorvão [...], fl. 146.
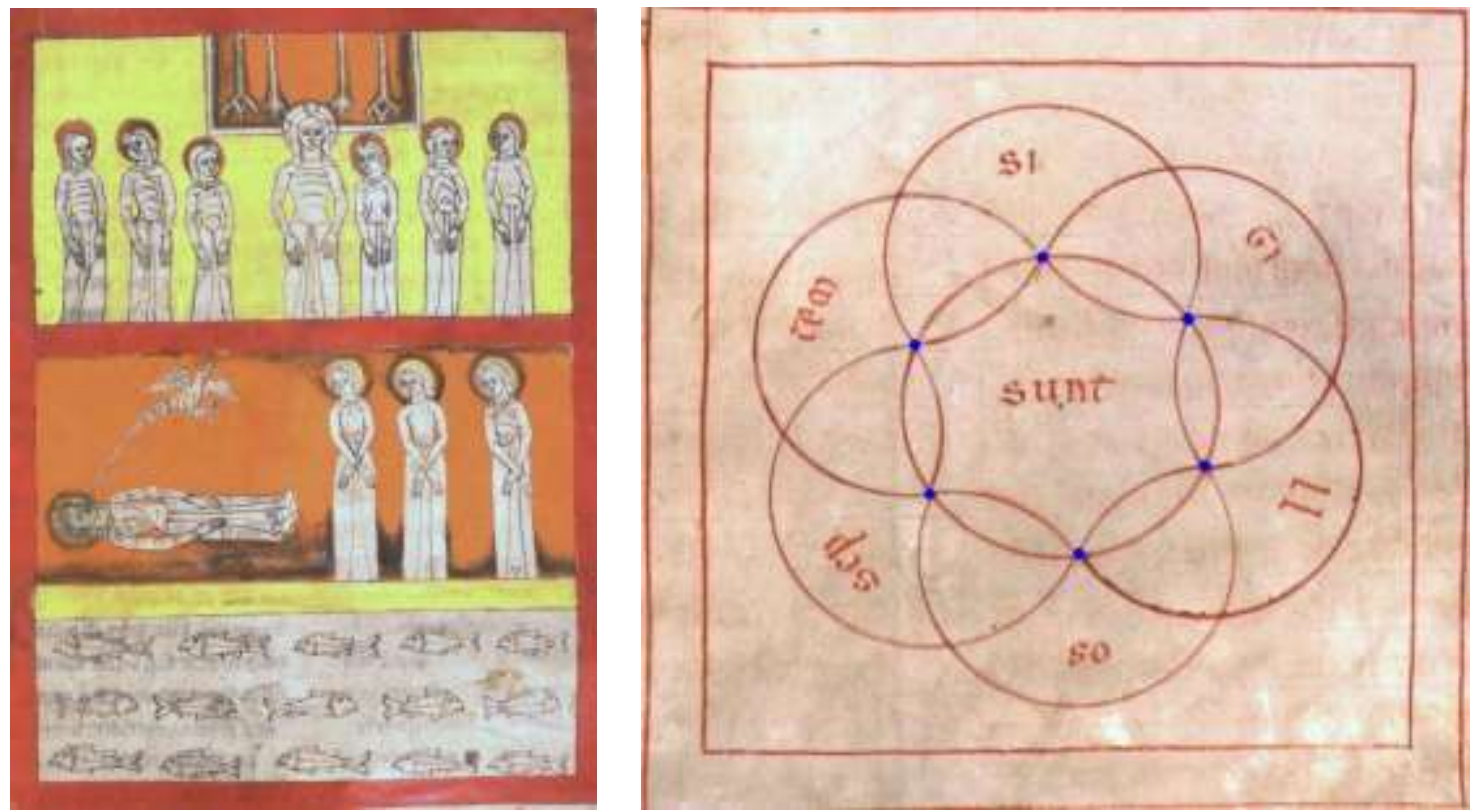

Fig. 42. Visão do trono de Deus. BEATO DE LIÉBANA, Commentarium in Apocalypsin; cópia ilustrada do Mosteiro de São Mamede de Lorvão [...], fl. 86.

Fig. 43. O silêncio no céu (manipulação nossa) BEATO DE LIÉBANA, Commentarium in Apocalypsin; cópia ilustrada do Mosteiro de São Mamede de Lorvão [...], fl. 134 
Ana de Oliveira DiAs, Commentarium in Apocalypsin: o número e a forma geométrica na tradição simbólica das ilustrações do «Beato» de São Mamede de Lorvão

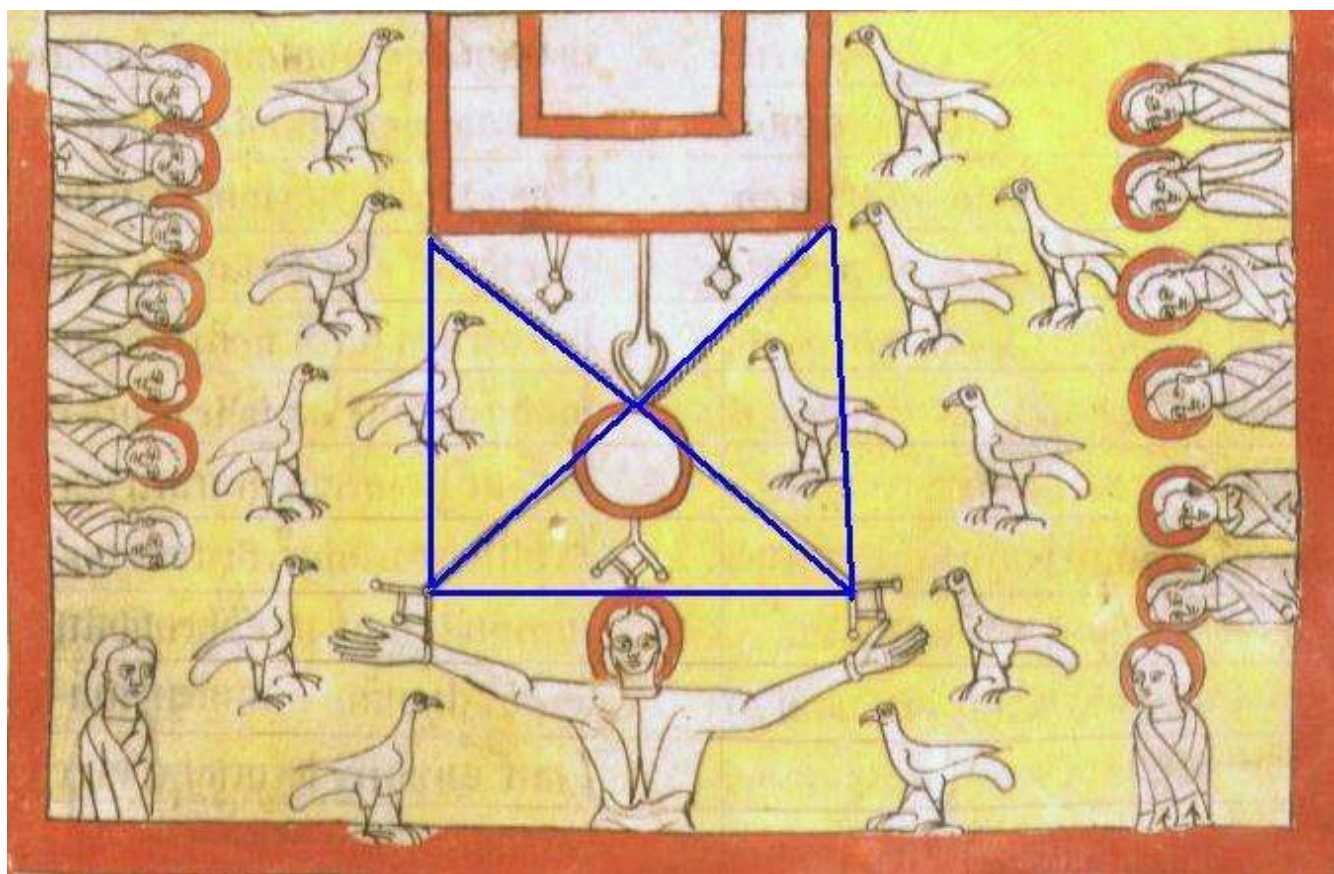

Fig. 44. As almas debaixo do altar (manipulação nossa) BEATO DE LIÉBANA, Commentarium in Apocalypsin; cópia ilustrada do Mosteiro de São Mamede de Lorvão[...], fl. 112.

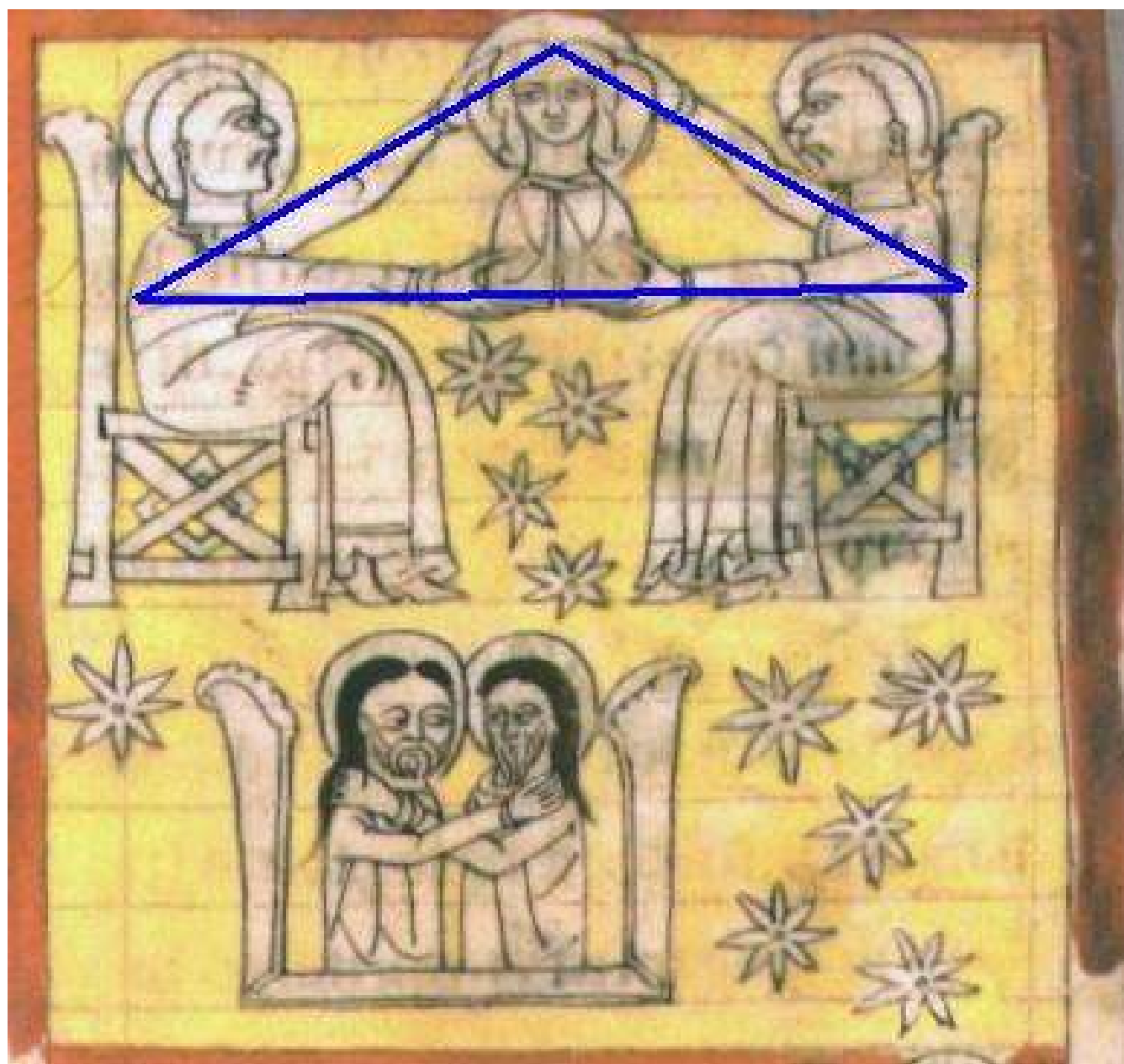

Fig. 45. As duas testemunhas (pormenor de ilustração manipulação nossa) BEATO DE LIÉBANA, Commentarium in Apocalypsin; cópia ilustrada do Mosteiro de São Mamede de Lorvão [...], fl. 150v. 
Ana de Oliveira DiAs, Commentarium in Apocalypsin: o número e a forma geométrica na tradição simbólica das ilustrações do «Beato» de São Mamede de Lorvão

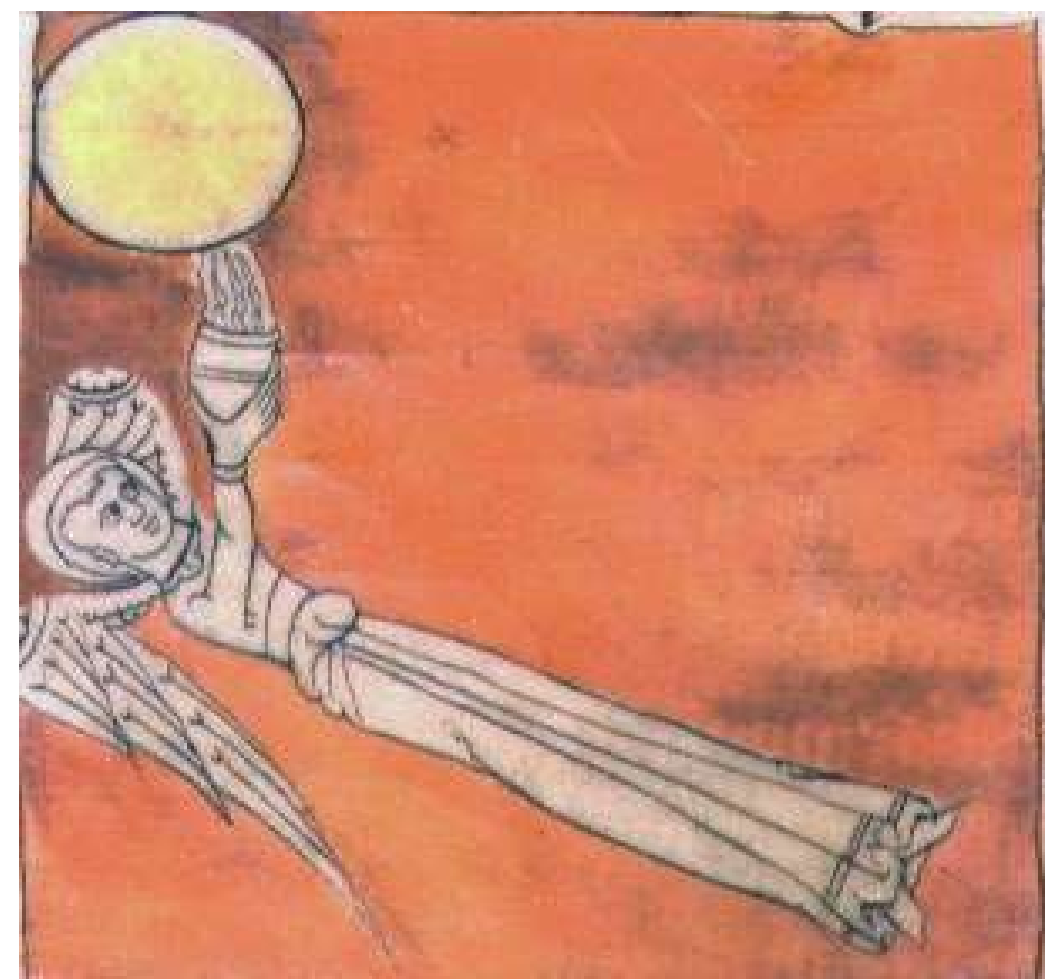

Fig. 46. A quinta trombeta. BEATO DE LIÉBANA, Commentarium in Apocalypsin; cópia ilustrada do Mosteiro de São Mamede de Lorvão [...], fl. 140v.
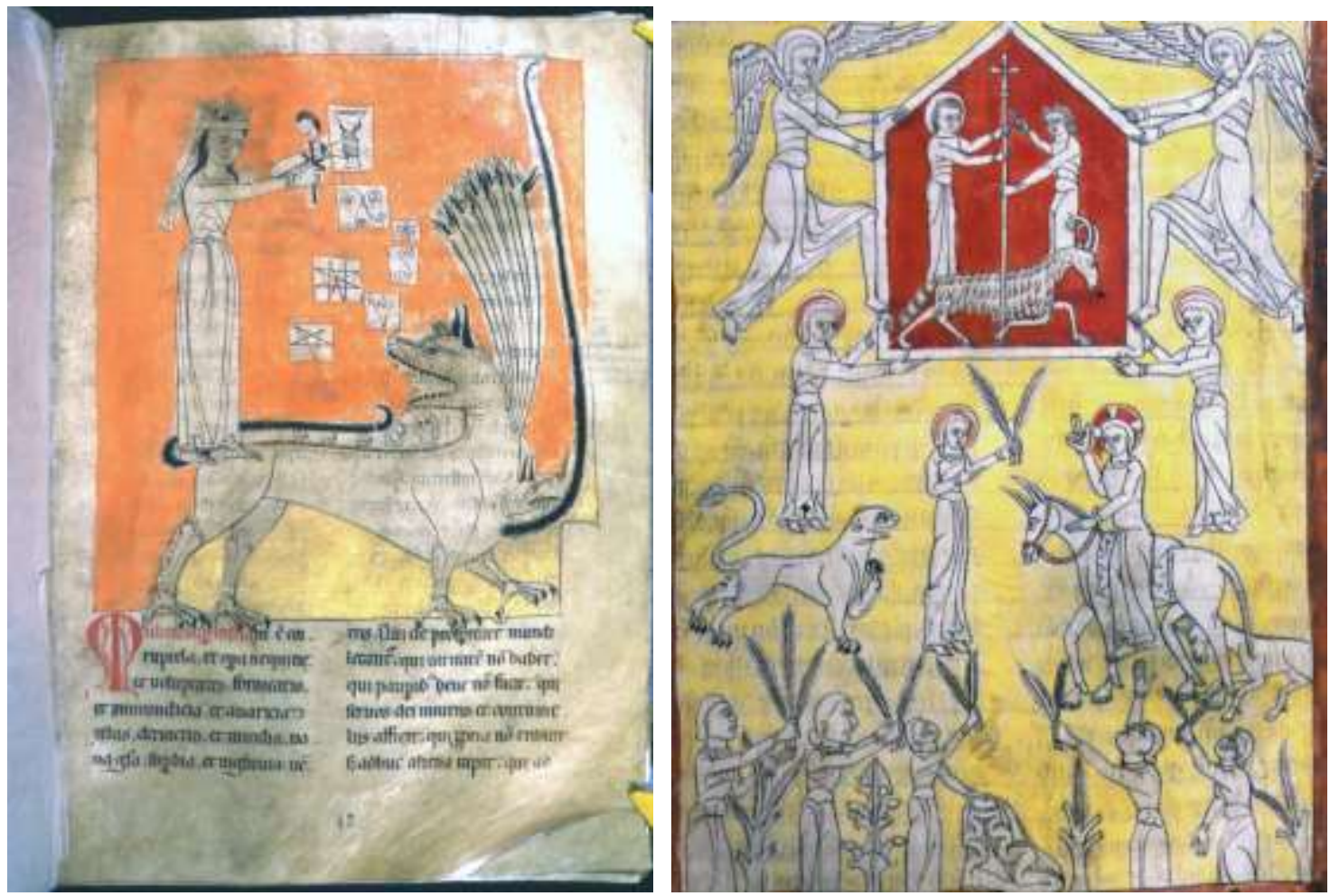

Fig. 47. A Mulher sobre a Besta.BEATO DE LIÉBANA, Commentarium in Apocalypsin; cópia ilustrada do Mosteiro de São Mamede de Lorvão [...], fl. 43.

Fig. 48. A Adoração do Cordeiro. BEATO DE LIÉBANA, Commentarium in Apocalypsin; cópia ilustrada do Mosteiro de São Mamede de Lorvão [...], fl. 120 
Ana de Oliveira DiAs, Commentarium in Apocalypsin: o número e a forma geométrica na tradição simbólica das ilustrações do «Beato» de São Mamede de Lorvão

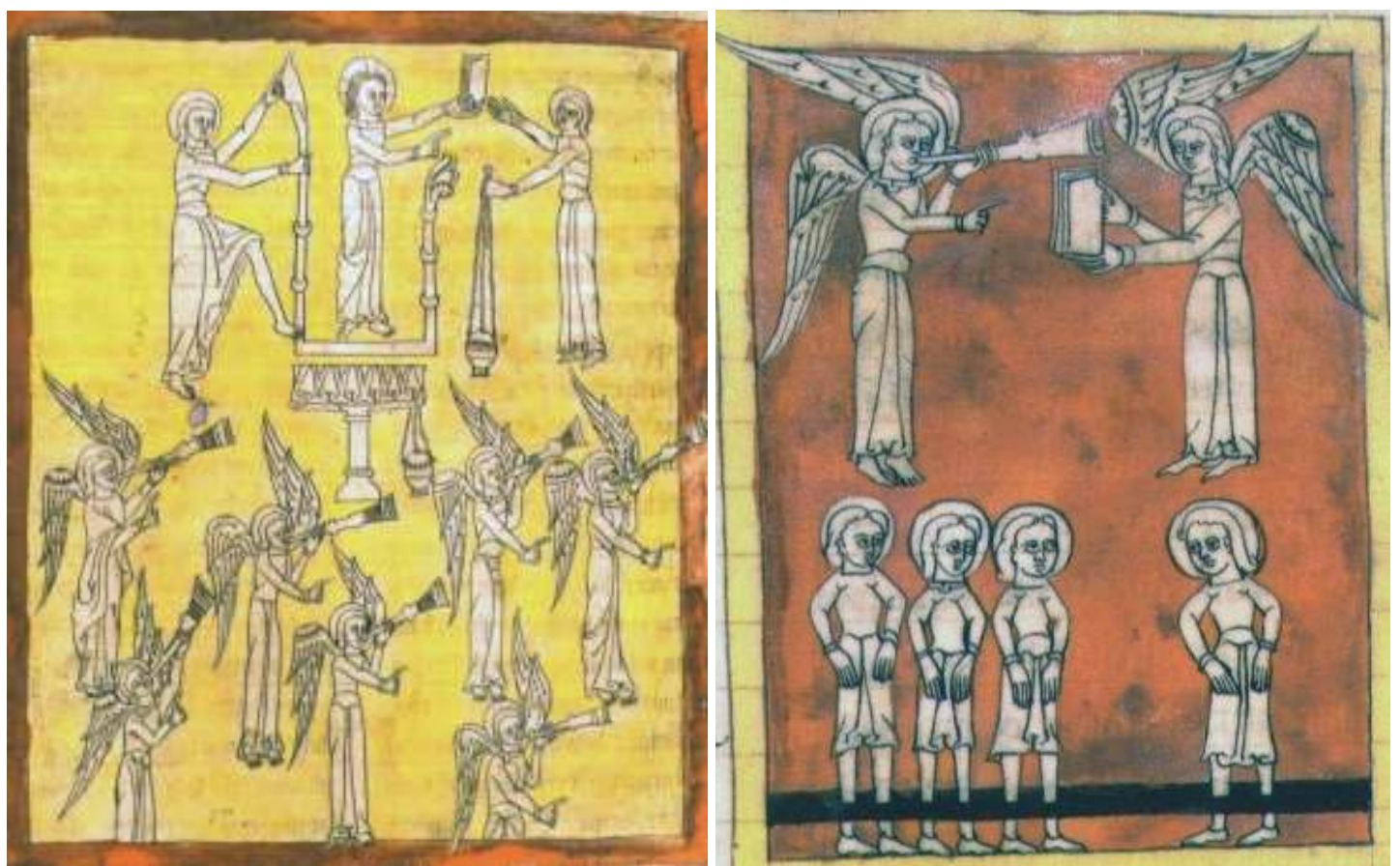

Fig. 49. Os sete anjos trombeteiros. BEATO DE LIÉBANA, Commentarium in Apocalypsin; cópia ilustrada do Mosteiro de São Mamede de Lorvão [...], fl. 135.

Fig. 50. A sexta trombeta. BEATO DE LIÉBANA, Commentarium in Apocalypsin; cópia ilustrada do Mosteiro de São Mamede de Lorvão [...], fl. 143.
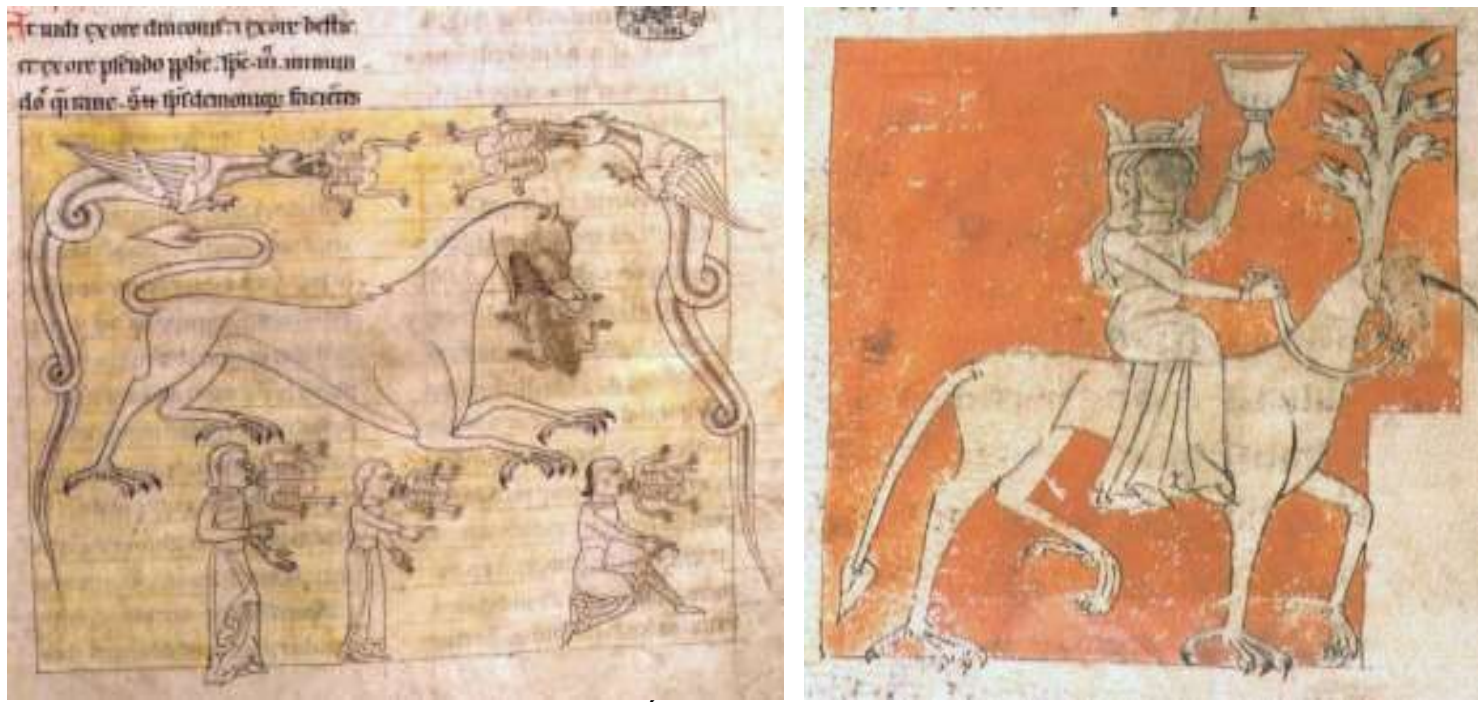

Fig. 51. O espiritos imundos. BEATO DE LIÉBANA, Commentarium in Apocalypsin; cópia ilustrada do Mosteiro de São Mamede de Lorvão [...], fl. 182.

Fig. 52. O Julgamento da Meretriz.BEATO DE LIÉBANA, Commentarium in Apocalypsin; cópia ilustrada do Mosteiro de São Mamede de Lorvão [...], fl. 186v. 
Ana de Oliveira DiAs, Commentarium in Apocalypsin: o número e a forma geométrica na tradição simbólica das ilustrações do «Beato» de São Mamede de Lorvão
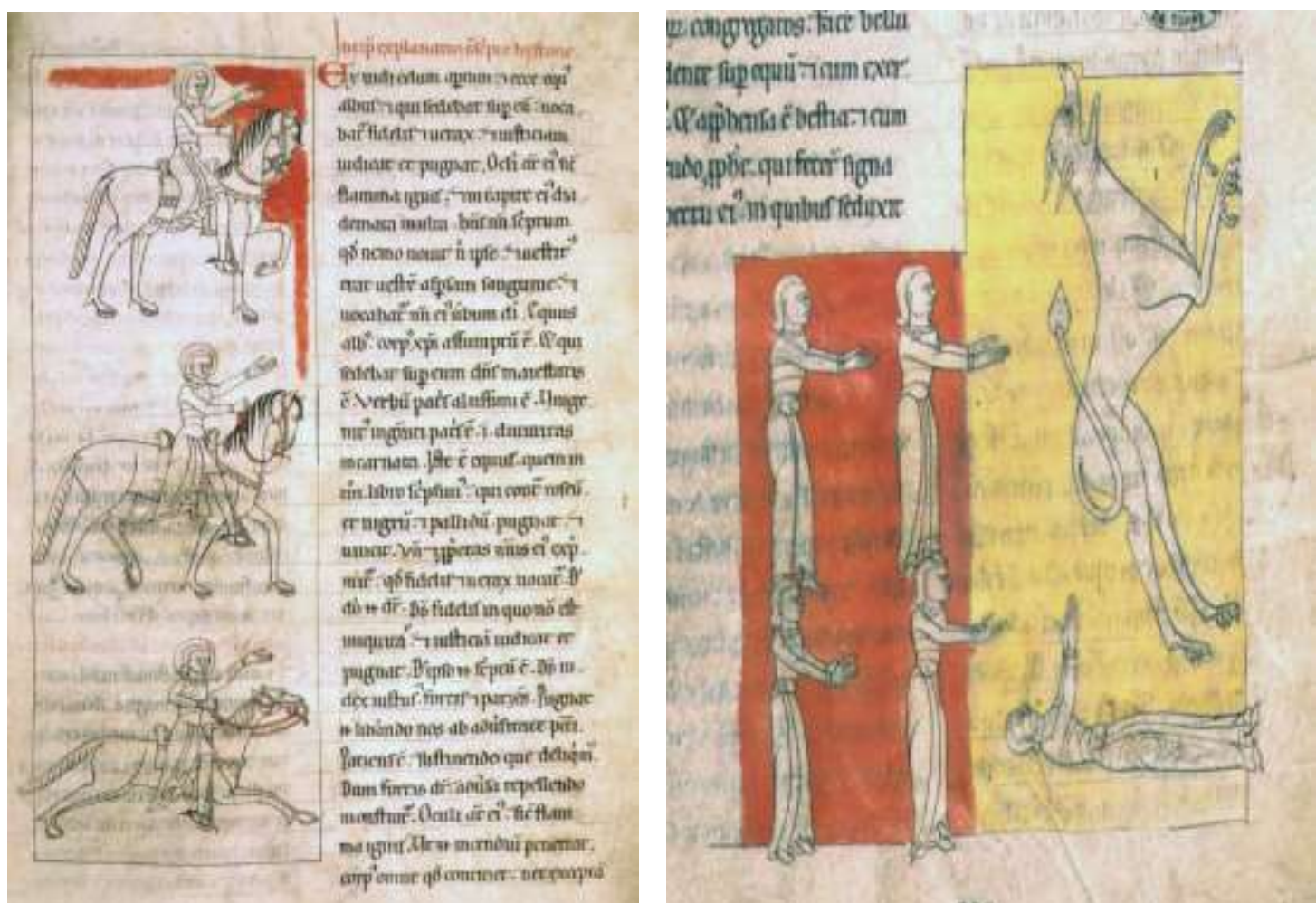

Fig. 53. O Exército do Céu. BEATO DE LIÉBANA, Commentarium in Apocalypsin; cópia ilustrada do Mosteiro de São Mamede de Lorvão [...], fl. 198.

Fig. 54. A Besta e os Reis. BEATO DE LIÉBANA, Commentarium in Apocalypsin; cópia ilustrada do Mosteiro de São Mamede de Lorvão [...], fl. 200.
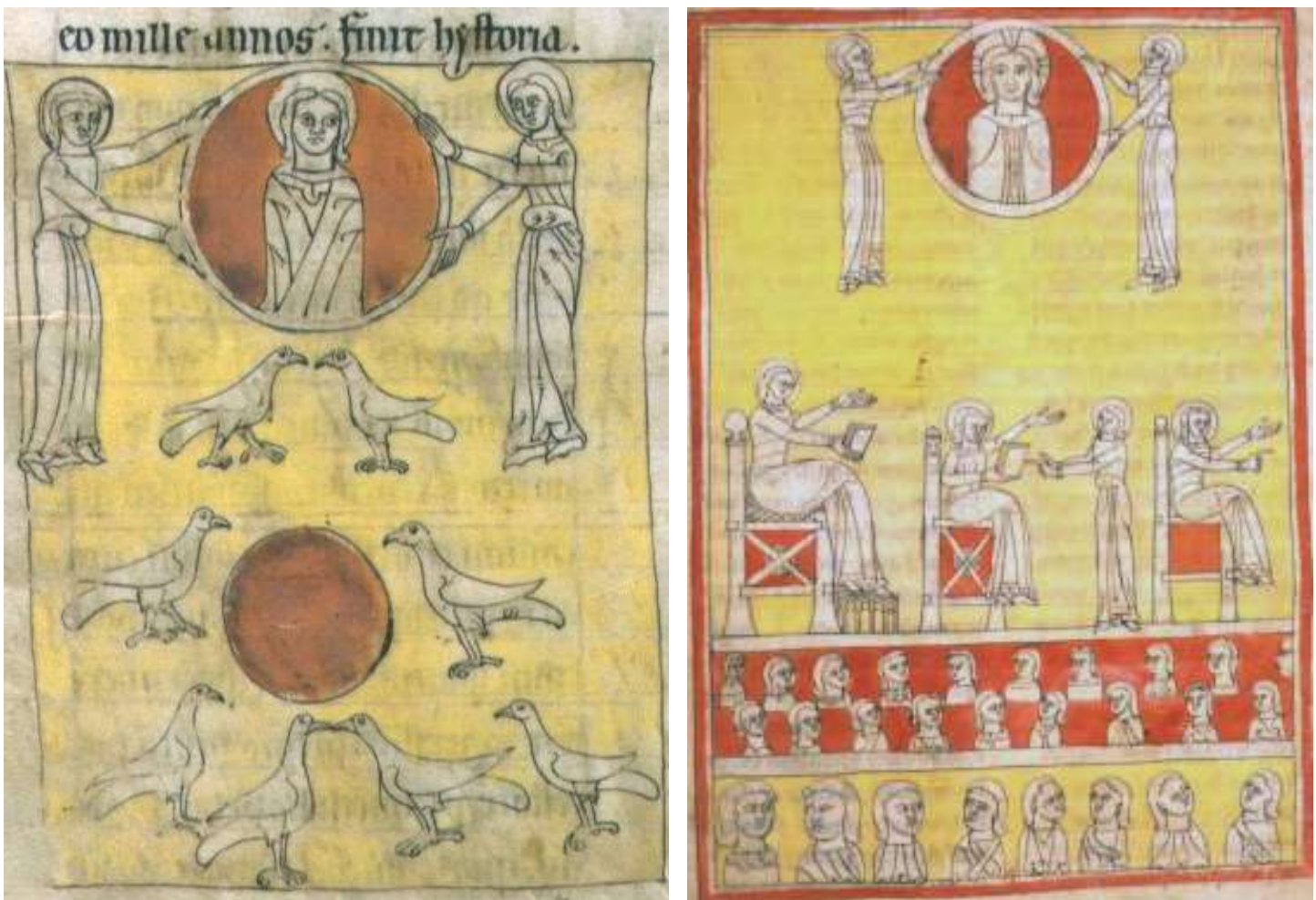

Fig. 55. As almas dos mártires. BEATO DE LIÉBANA, Commentarium in Apocalypsin; cópia ilustrada do Mosteiro de São Mamede de Lorvão [...], fl. 202v.

Fig. 56. O Juízo Final. BEATO DE LIÉBANA, Commentarium in Apocalypsin; cópia ilustrada do Mosteiro de São Mamede de Lorvão [...], fl. 207. 
Ana de Oliveira DiAs, Commentarium in Apocalypsin: o número e a forma geométrica na tradição simbólica das ilustrações do «Beato» de São Mamede de Lorvão
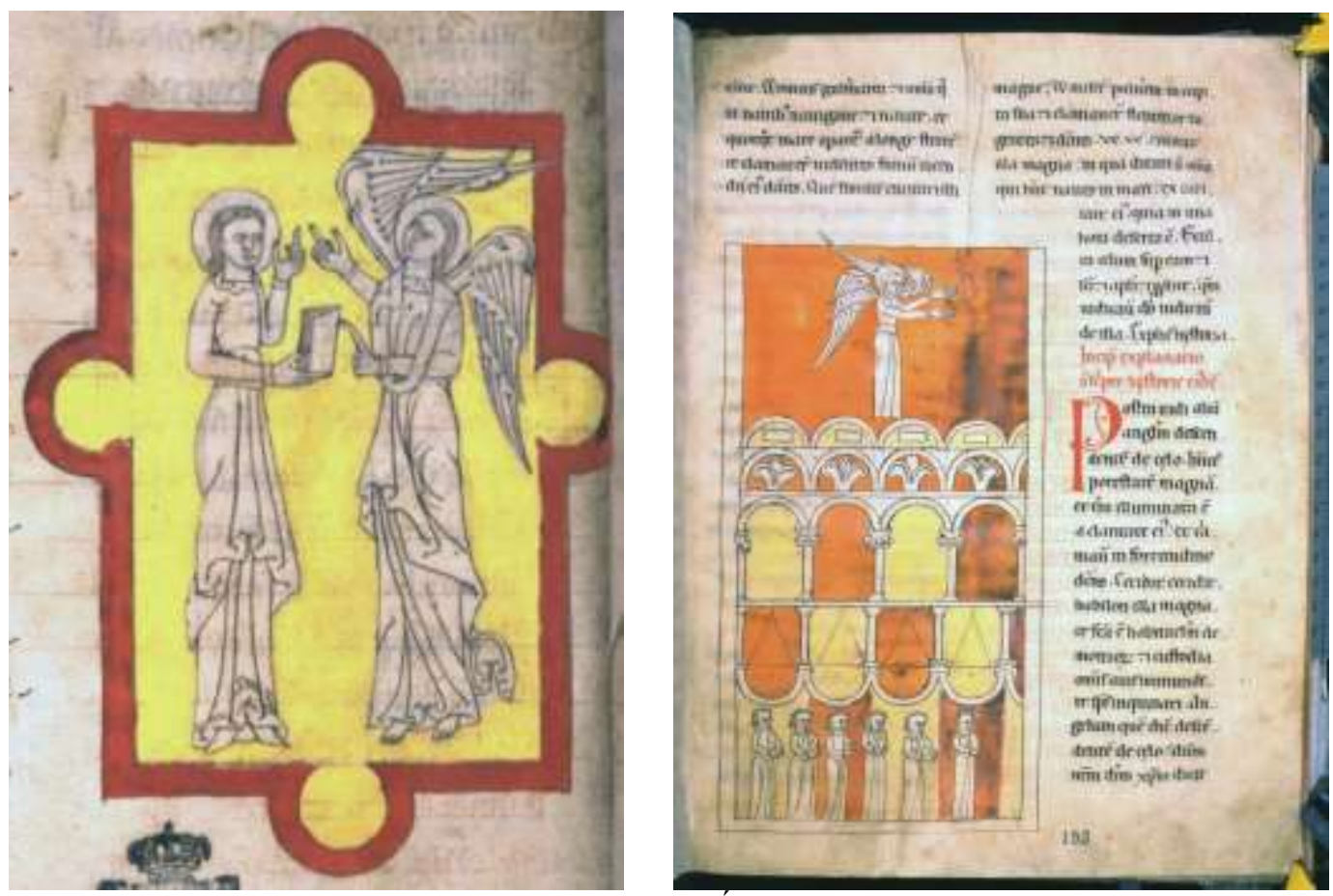

Figs. 57. Mensagem à Igreja de Sardes. BEATO DE LIÉBANA, Commentarium in Apocalypsin; cópia ilustrada do Mosteiro de São Mamede de Lorvão [...], fl.68.

Fig. 58. A queda da Babilónia. BEATO DE LIÉBANA, Commentarium in Apocalypsin; cópia ilustrada do Mosteiro de S. Mamede de Lorvão [...], fl.193.
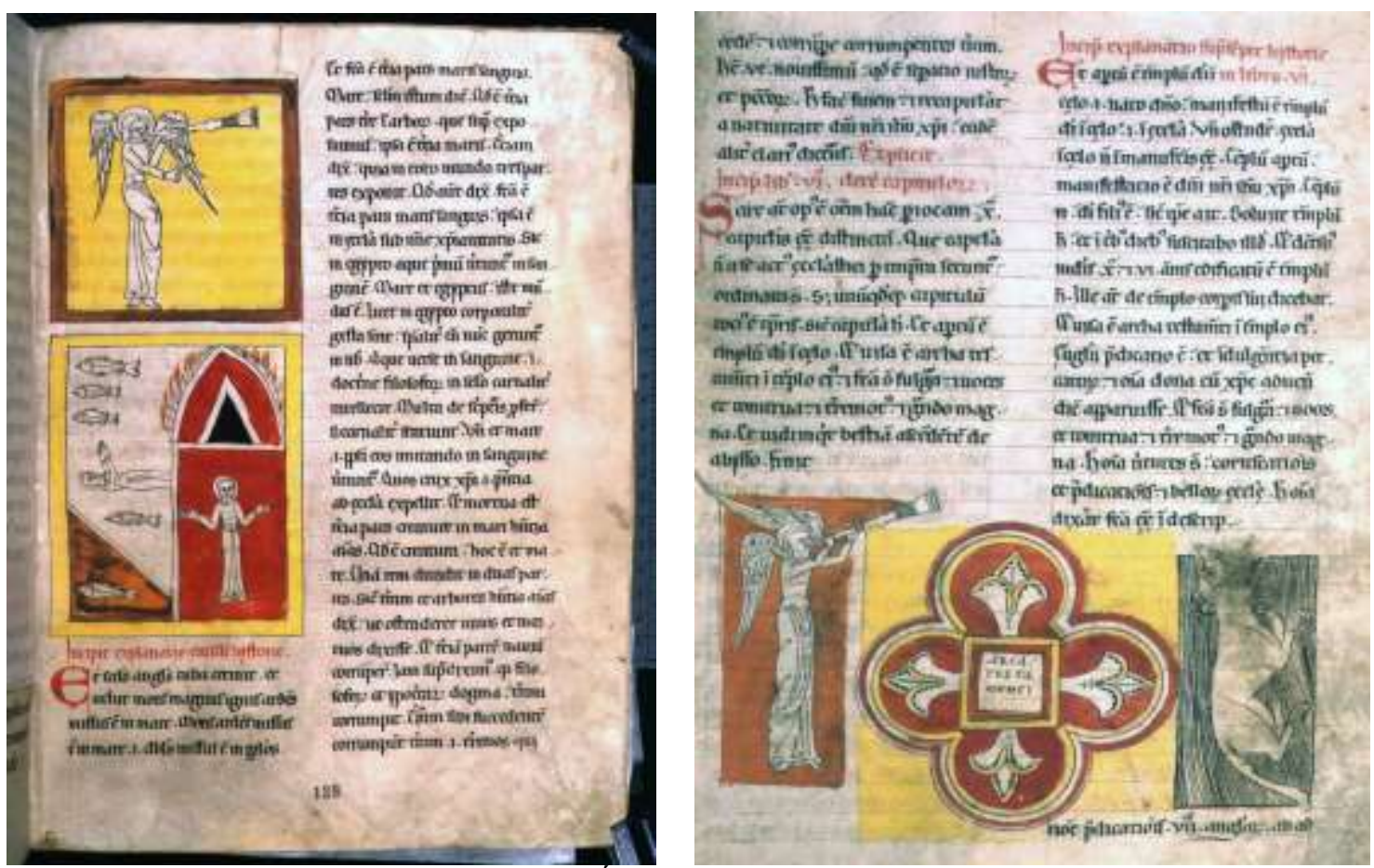

Fig. 59. A segunda trombeta. BEATO DE LIÉBANA, Commentarium in Apocalypsin; cópia ilustrada do Mosteiro de S. Mamede de Lorvão [...], fl. 138.

Fig. 60. A Arca da Aliança. BEATO DE LIÉBANA, Commentarium in Apocalypsin; cópia ilustrada do Mosteiro de São Mamede de Lorvão [...], fl. 152 
Ana de Oliveira DiAs, Commentarium in Apocalypsin: o número e a forma geométrica na tradição simbólica das ilustrações do «Beato» de São Mamede de Lorvão

\section{Fontes e Bibliografia}

\section{Fontes}

\subsection{Fontes Manuscritas}

Direção-Geral de Arquivos/Arquivo Nacional da Torre do Tombo (DGARQ/ANTT). Casa- Forte:

Ordem de Cister, Mosteiro de São Mamede de Lorvão,

BEATO DE LIÉBANA, Commentarium in Apocalypsin; cópia ilustrada do Mosteiro de S. Mamede do Lorvão, Livro 44 (C.F. 160).

HUGUE DE FOUILLOY, De Avibus, cópia ilustrada do Mosteiro de S. Mamede de Lorvão, Livro 5 (C.F 90).

\subsection{Fontes Impressas}

BEATO DE LIÉBANA, "Commentarium in Apocallyspin", in Obras completas y complementarias (ed. de Juan ECHEGARAY, et. al), Madrid, Biblioteca de Autores Cristianos, 2004.

Biblia Sagrada (coord. de Herculano ALVES e José Augusto RAMOS) Lisboa, Difusora Bíblica, 2003.

GIL, Juan (ed.), Corpus scriptorum muzarabicorum, II vols., Madrid, Instituto Antonio Nebrija, 1973.

FERNÁNDEZ CATÓN, José (dir.), Liber testamentorum coenobii laurbanensis, II vols., Léon, Centro de Estudios e investigación «San Isidoro», Caja España de Inversiones, Archivo histórico diocesano, 2008.

FLÓREZ, Henrique (ed.), Viage de Ambrosio de Morales por orden del rey D. Felipe II a los reinos de León y Galicia y principado de Asturias para reconocer las reliquias de santos, sepulcros reales y libros manuscritos de las catedrales y monasterios, Madrid, Antonio Martin, 1765.

ISIDORO HISPALENSIS, Etymologiae, (ed. de Jose RETA OROZ e Manuel MARCOS CASQUERO), vol. I, Madrid, Biblioteca de Autores Cristianos, 1993.

IDEM, Liber Nvmerorvm, (ed. de Jean-Yves GUILLAUMIN), Paris, Les Belles Lettres, 2006.

AGOSTINHO DE HIPONA, A Cidade de Deus, (trad. de J. Dias PEREIRA), III vols., Lisboa, Fundação Calouste Gulbenkian, 1993.

IDEM, Obras filosóficas (ed. bilingue de Fr. Victorino CAPAGANA, et. al.), Madrid, Biblioteca de Autores Cristianos, 1947.

MIGNE,J-P. (ed.), Patrologiae cursus completus:ommium SS. Patrum, Doctorum scriptorum ecclesiasticorum, sive latinorum, vol. XLVI, Turnhoult, Brepols, 19701985.

IDEM, Patrologiae cursus completus : ommium SS. Patrum, Doctorum scriptorum ecclesiasticorum, sive latinorum, vol. CI, Turnhoult, Brepols, 1970-1985.

\section{Bibliografía}

\subsection{Obras de carácter geral}

AZEVEDO, Carlos Moreira (dir.), História religiosa de Portugal, vol. I, Lisboa, Temas \& Debates, 2004.

BOGAERT, Pierre Maurice, et.al. (dir.), Dictionnaire encyclopedique de la Bible, Turnhoult, Brepols, 2002.

CHEVAliER, Jean, GHEERBRANT, Alain (dir.), Dicionário dos Símbolos - Mitos, 
Ana de Oliveira DiAs, Commentarium in Apocalypsin: o número e a forma geométrica na tradição simbólica das ilustrações do «Beato» de São Mamede de Lorvão

sonhos, costumes, gestos, formas, figuras, cores, números, Lisboa, Teorema, 1982.

CHRISTE, Yves, L`Apocalypse de Jean, Paris, Picard Éditeur, 1996. DONALD, J. M.

C. (dir.), New Catholic Encyclopedia, vol. I, Washington, McGrow-

Hill Book Company, 1967.

GOMES, Saul, "A religião dos clérigos: vivências espirituais, elaboração doutrinal e transmissão cultural", in História Religiosa de Portugal - Formação e limites da Cristandade (dir. de Carlos Moreira de AZEVEDO), vol. I, Lisboa, Temas \& Debates, 2004, pp. 339-421.

KENNA, S. J. M. C., “Adoptionism”, in New Catholic Encyclopedia, (dir. de J. M. C. DONALD), vol. I, Washington, McGrow-Hill Book Company, 1967, pp. 140-141.

MATTOSO, José (dir.), História de Portugal, vol. II - A Monarquia Feudal (10961480), Lisboa, Círculo de Leitores, 1993.

PEREIRA, Paulo (dir.), História da Arte Portuguesa, vol. I, Lisboa, Círculo de Leitores, 1995.

ROSA, Maria de Lurdes, "A religião no século, vivência e devoções dos leigos", in História Religiosa de Portugal - Formação e limites da Cristandade (dir. de Carlos Moreira de AZEVEDO), vol. I, Lisboa, Temas \& Debates, 2004, pp. 423-544.

SARTORE, Domenico, TRIACCA, Achille (dir.), Dictionnaire encyclopédique de la liturgie, II vols., Turnhoult, Brepols, 1992.

\subsection{Estudos}

Actas del Simpósio para el Estúdio de los Códices del "Comentário al Apocalipsis" de

Beato de Liébana, III vols., Madrid, Joyas Bibliográficas, 1978-1980. AILLET, Cyrille (dir.), Existe una identidad mozárabe? Historia, lengua y cultura de los cristianos de al-Andalus (siglos IX-XII), Madrid, Casa de Velázquez, 2008.

ANDRADE, Amélia Aguiar, SILVA, José Custódio Vieira da, Estudos medievais: quotidiano medieval - imaginário, representação e práticas, Lisboa, Livros Horizonte, 2004.

AZEVEDO, Ruy de, "O mosteiro de Lorvão na Reconquista cristã", in Arquivo Histórico de Portugal, 1, 1932 [separata, Lisboa, 1933], pp. 5 - 61.

BARRUCAND, Marianne, "Les Enluminures de l'époque almohade: frontispices et 'Unwan-s"in, Los Almohades: Problemas y Perspectivas (dir. Patrice CRESSIER, et. $a l)$, vol. I, Madrid, Consejo Superior de Investigaciones Científicas, 2005, pp. 71121.

BORGES, Nelson Correia, Arte monástica em Lorvão - sombra e realidade - das origens a 1737 (dissertação de doutoramento em História da Arte apresentada à Faculdade de Letras da Universidade de Coimbra), vol. I, Lisboa, Fundação Calouste Gulbenkian, Fundação para a Ciência e Tecnologia, 2002.

BORGES, Thiago José, Do texto ao traçado cartográfico: as representações das Sortes Apostolorum nos mapa-múndi dos Beatos - séculos X-XIII - (dissertação de mestrado apresentada à Faculdade de Letras da Universidade de Lisboa), Lisboa, 2010, exemplar mimeografado.

BRACH, Jean-Pierre, Il simbolismo dei numeri, Roma, Edizione Arkeios, 1999.

BRANCO, Maria João, "Reis, condes, mosteiros e poderes: o mosteiro de Lorvão no contexto político do reino de Leão (sécs. IX-XII) ", in Liber Testamentorum coenobii laurbanensis (dir. de José FERNÁNDEZ CATÓN), volume de estudos, Léon, Centro de Estudios e Investigación «San Isidoro», Caja España de inversiones, Archivo Histórico Diocesano, 2008, pp. 27-77.

BROWN, Michelle P., Understanding Illuminated Manuscripts - a guide to technical terms, Londres, British Library, 1994. 
Ana de Oliveira DiAs, Commentarium in Apocalypsin: o número e a forma geométrica na tradição simbólica das ilustrações do «Beato» de São Mamede de Lorvão

BROWN, Peter, Augustin of Hippo - a biography, Berkeley, University of California Press, 2000.

CAMPOS, Sergio Álvarez, "Fuentes literarias de Beato de Liébana", in Actas del Simposio para el estudio de los códices del «Comentario al Apocalipsis» de Beato de Liébana, vol. I, Madrid, Joyas Bibliográficas, 1978, pp. 117-162.

CHRISTE, Yves, "The Apocalypse in the monumental art of eleventh trough thirteenth centuries", in The Apocalypse in the Middle Ages (dir. de Richard K. EMMERSON e Bernard MCGINN), Ithaca, Cornell University Press, 1992, pp. 234-258.

COCKSHAW, Pierre (comissariado científico e geral de), Los Beatos, catálogo de exposição bibliográfica, Chapelle de Nassau, Bibliothèque Royal Albert I ${ }^{\text {er }}, 1985$.

CRESSIER, Patrice, et. al, Los Almohades: Problemas y Perspectivas, vol. I, Madrid, Consejo Superior de Investigaciones Científicas, 2005.

DIAS, Ana de Oliveira, "Os «mischwesen» nas Tentações de Santo Antão de Hieronymus Bosch - as estruturas do imaginário medieval nos alvores da ÉpocaModerna", in Seminário Internacional Tarouca e Cister: O Imaginário e o património de Cister no Douro, Tarouca, Câmara Municipal de Tarouca, (no prelo).

DÍAZ Y DÍAZ, Manuel C., Códices visigóticos en la monarquia leonesa, Léon, Centro de estudios e investigación San Isidoro, 1983.

IDEM, "La tradición del texto de los Comentarios al Apocalipsis", in Actas del Simposio para el estudio de los códices déComentario al Apocalipsis 'de Beato de Liébana, vol. I, Madrid, Joyas Bibliográficas, 1978, pp. 165- 191.

IDEM, "Le texte de «Los Beatos»", in Los Beatos, catálogo de exposição bibliográfica, (comissariado científico e geral de Peter COCKSHAW), Chapelle de Nassau, Biblioteca real Alberto I, 1985, pp. 9-17.

IDEM, "Los mozárabes. Una minoría combativa", in Existe una identidad mozárabe? Historia, lengua y cultura de los cristianos de al-Andalus (siglos IX-XII), (dir. de Cyrille AILLET), Madrid, Casa de Velázquez, 2008, pp. 1-8.

DUBY, Georges, As três ordens ou o imaginário do Feudalismo, Lisboa, Editorial Estampa, 1994.

IDEM, O Ano Mil, Lisboa, Edições 70, 2002.

ECHEGARAY, Joaquín González, "Beato de Liébana y los terrores del año 800”, in Milenarismos y milenaristas en la Europa Medieval, IX Semana de Estudios Medievales, Nájera, 1999, pp. 87-100.

ECO, Umberto, VÁZQUEZ DE PARGA, Luis, Miniaturas del "Beato" de Fernando I y Sancha (Manuscrito B. N. Madrid Vit. 14-2), Milão, Franco Maria Ricci Editore, 1983.

EGRY, Anne de, Um estudo de O Apocalipse do Lorvão e a sua relação com as ilustrações medievais do Apocalipse, Lisboa, Fundação Calouste Gulbenkian, 1972.

EMMERSON, Richard K., "The Apocalypse in Medieval Culture", in The Apocalypse in the Middle Ages (dir. de Richard K. EMMERSON e Bernard MCGINN), Ithaca, Cornell University Press, 1992, pp. 293-332.

FAUVARQUE, Bertrand, "L`Apocalipyse en Espagne (VII-VIII siécles)", in Mélanges de la Casa de Velázquez, vol. XXXII, s.1, 1996, pp. 217-236.

FERRER GRENESCHE, Juan-Miguel, Curso de liturgia hispano-mozárabe, Toledo, Estudio Teológico de San Ildefonso, 1995.

FLANIGAN, C. Clifford, "The Apocalypse and the Medieval Liturgy", in The Apocalypse in the Middle Ages (dir. de Richard K. EMMERSON e Bernard MCGINN), Ithaca, Cornell University Press, 1992, pp. 333-351.

FONTAINE, Jacques, El mozárabe, Madrid, Encuentro, 1984. 
Ana de Oliveira DiAs, Commentarium in Apocalypsin: o número e a forma geométrica na tradição simbólica das ilustrações do «Beato» de São Mamede de Lorvão

IDEM, "Fuentes y tradiciones paleocristianas en el método espiritual de Beato", in Actas del Simposio para el estudio de los códices del «Comentario al Apocalipsin» de Beato de Liébana, vol. I, Madrid, Joyas Bibliográficas, 1978, pp. 77- 101.

IDEM, Isidore de Séville: genèse et originalité de la culture hispanique au temps des Wisigoths, Turnhoult, Brepols, 2000.

IDEM, L'art préroman hispanique 1, Paris, Zodiaque, 1973-1977.

FREEMAN, Leslie G., "Elementos simbolicos en la obra de Beato", in Beato de Liébana: Obras completas y complementarias (ed. de Juan ECHEGARAY, et. al), Madrid, Biblioteca de Autores Cristianos, 2004, pp. 33-56.

GIL, Juan, "Los terrores del año 800", in Actas del Simpósio para el estudio de los códices del "Comentário al Apocalipsis" de Beato de Liébana, vol. I, Madrid, Joyas Bibliográficas, 1978, pp. 215- 247.

GHYKA, Matilda, Le nombre d'or et rythmes pythagoriciens dans le développement de la civilization ocidentale, Paris, Gallimar, 2000.

GOUVEIA, Mário de, O limiar da tradição no moçarabismo conimbricense: os anais de Lorvão e a memória monástica do território de fronteira (sécs. XI e XII), (dissertação de mestrado apresentada à Faculdade de Ciências Sociais e Humanas da Universidade Nova de Lisboa), Lisboa, 2008, exemplar mimeografado.

HAMEL, Christopher de, Manuscript illumination - history and techniques, Londres, British Library, 2001.

KLEIN, Peter K., Beato de Liébana: la ilustración de los manuscritos de Beato y el Apocalipsis de Lorvão (trad. de Beatriz Mariño), Valéncia, Patrimonio Ediciones, 2004.

IDEM, "Introducion: The Apocalypse in Medieval Art", in The Apocalypse in the Middle Ages, (dir. de Richard K. EMMERSON e Bernard MCGINN), Ithaca, Cornell University Press, 1992, pp. 159-199.

IDEM, "La tradición pictórica de los Beatos", in Actas del Simpósio para el estudio de los códices déCOmentário al Apocalipsis` de Beato de Liébana, vol. II, Madrid, Joyas Bibliográficas, 1980, pp. 83- 106.

LE GOFF, Jacques, O Imaginário medieval, Lisboa, Estampa, 1994. IDEM, $O$ maravilhoso e o quotidiano no Ocidente medieval, Lisboa, Estampa, 1983.

LUACES YARZA, Joaquin, La Miniatura Medieval en la Peninsula Ibérica, Murcia, Nausícaa, 2007.

MACEDO, Francisco Pato de, O Apocalipse do Lorvão e os "beatos" peninsulares, (Relatório de aula teórico-prática para prestação de provas de aptidão pedagógica e capacidade científica apresentada à Faculdade de Letras da Universidade de Coimbra), Coimbra, 1988, exemplar mimeografado.

MARTINS, Armando Alberto, Os Moçárabes na génese da cultura portuguesa: alguns aspectos, (provas de aptidão pedagógica e capacidade científica apresentada à Faculdade de Letras da Universidade de Lisboa), Lisboa, 1989, exemplar mimeografado.

MATTER, E. Ann, "The Apocalypse in early medieval exegesis", in The Apocalypse in the Middle Ages, (dir. de Richard K. EMMERSON e Bernard MCGINN), Ithaca, Cornell University Press, 1992, pp. 38-50.

MATTOSO, José, Religião e cultura na Idade Média portuguesa, Lisboa, Imprensa Nacional Casa da Moeda, 1997.

IDEM, "A introdução da Regra de S. Bento na Península Ibérica", in Religião e cultura na Idade Média portuguesa, Lisboa, Imprensa Nacional Casa da Moeda, 1997, pp. 73- 90.

IDEM, "O imaginário da iluminura medieval", in A iluminura em Portugal. Identidade 
Ana de Oliveira DiAs, Commentarium in Apocalypsin: o número e a forma geométrica na tradição simbólica das ilustrações do «Beato» de São Mamede de Lorvão

e Influências, catálogo de exposição bibliográfica (comissariado científico e geral de Maria Adelaide MIRANDA), Lisboa, Ministério da Cultura - Biblioteca Nacional, 1999, pp. 25-37.

IDEM, Poderes invisíveis: o imaginário medieval, Lisboa, Círculo dos Leitores, 2001.

IDEM,"Sobrevivências do monaquismo frutuosiano em Portugal durante a Reconquista", in Religião e cultura na Idade Média portuguesa, Lisboa, Imprensa Nacional Casa da Moeda, 1997, pp. 11- 28.

MCGINN, Bernard, "Introduction: John's Apocalypse and the Apocalyptic mentality", in The Apocalypse in the Middle Ages, (dir. de Richard K. EMMERSON e Bernard MCGINN), Ithaca, Cornell University Press, 1992, pp. 3-19.

MENTRÉ, Mireille, RICHÉ Pierre, et. al. Illuminated manuscripts of medieval Spain, Londres, Thames \& Hudson, 1996.

IDEM, La peinture mozárabe, Paris, Presses Universitaires de Paris Sorbornne, 1984. MESCHKOWSKI, Herbert, Ways of thought of great mathematicians: an approach to the history of mathematics, São Francisco, CA, Holden-Day, 1964.

MIRANDA, Maria Adelaide, "A iluminura românica em Portugal", in A iluminura em Portugal. Identidade e Influências, catálogo de exposição bibliográfica (comissariado científico e geral de Maria Adelaide MIRANDA), Lisboa, Ministério da Cultura - Biblioteca Nacional, 1999, pp. 127-142.

MOLÉNAT, Jean- Pierre, "La fin des chrétiens arabisés d'al- Andaluz. Mozarabes de Tolède et du Gharb au XII ${ }^{\mathrm{e}}$ siècle.”, in Existe una identidad mozárabe? Historia, lengua y cultura de los cristianos de al-Andalus - siglos IX-XII - (dir. de Cyrille AILLET), Madrid, Casa de Velázquez, 2008, pp. 287- 297.

NASCIMENTO, Aires Augusto, "A iluminura hispânica primitiva: fragmentos de um universo cultural", in A iluminura em Portugal. Identidade e Influências, catálogo de exposição bibliográfica (comissariado científico e geral de Maria Adelaide MIRANDA), Lisboa, Ministério da Cultura - Biblioteca Nacional, 1999, pp. 111125.

IDEM, “A mise-en-page, base operativa de reflexão codicológica: dados e problemas de fundos medievais portugueses", in Actas del VIII Coloquio del comité internacional de paleografía latina - Estudos y ensaios, Madrid, Joyas Bibliográficas, 1990, pp. 139- 147.

IDEM, "[Commentarium in Apocalypsin / Beato de Liébana]", in A iluminura em Portugal. Identidade e Influências, catálogo de exposição bibliográfica (comissariado científico e geral de Maria Adelaide MIRANDA) Lisboa, Ministério da Cultura - Biblioteca Nacional, 1999, pp. 166-169.

IDEM, "Mosteiro de Lorvão: A História possível dos seus tempos antigos", in Liber Testamentorum coenobii laurbanensis, (dir. de José FERNÁNDEZ CATÓN), volume de estudos, Léon, Centro de estudios e investigación «San Isidoro», Caja España de inversiones, Archivo histórico diocesano, 2008, pp. 81-156.

IDEM, "O «scriptorium» medieval, instituição matriz do livro", in A iluminura em Portugal. Identidade e Influências, catálogo de exposição bibliográfica (comissariado científico e geral de Maria Adelaide MIRANDA), Lisboa, Ministério da Cultura - Biblioteca Nacional, 1999, pp. 53-108.

NEUSS, Wilhelm, O comentário ao Apocalipse de Lorvão e suas iluminuras, Coimbra, Faculdade de Letras da Universidade de Coimbra, 1929.

PEIXEIRO, Horácio Augusto, Um olhar sobre a iluminura do Apocalipse do Lorvão, (Dissertação para Prof. Coordenador do Instituto Politécnico de Tomar), Tomar, 1998, exemplar mimeografado.

PINELL, Jordi, Liturgia hispánica, Barcelona, Biblioteca Liturgica, 1998. 
Ana de Oliveira DiAs, Commentarium in Apocalypsin: o número e a forma geométrica na tradição simbólica das ilustrações do «Beato» de São Mamede de Lorvão

REYNOLDS, Leighton D., WILSON, Nigel G., Copisti e Filologi - La tradizione dei classici dall Antichità ai Tempi Moderni, Pádua, Editrice Antenore, 1987. RIGON, Fernando, Arte dei numeri - letture iconografiche, Milão, Skira, 2006.

PASTOUREAU, Michel, Une Histoire Symbolique du Moyen Age Occidental, Paris, Édition de Seuil, 2004.

IDEM, "Quadrature del tempo", in Arte dei Numeri - letture iconografiche, Milão, Skira, 2006, pp. 77-98.

IDEM,"Settenari di sintesi", in Arte dei Numeri - letture iconografiche, Milão, Skira, 2006, pp.117-196.

IDEM, "Sole e luna, il binomio del cielo", in Arte dei Numeri - letture iconografiche, Milão, Skira, 2006, pp. 33-50.

RINCÓN ÁlVAREZ, Manuel, Mozárabes y Mozarabias, Salamanca, Ediciones Universidad de Salamanca, 2003.

ROCHA, Jorge da Silva, L'Image dans le Beatus de Lorvão: Figuration, composition et visualité dans les enluminures du commentaire à l'Apocalypse attribué au scriptorium du monastère de São Mamede de Lorvão - 1189, IV vol., (tese de doutoramento apresentada à Université Libre de Bruxelles, Faculté de Philosophie et Lettres), Bruxelas, 2007/2008, exemplar mimeografado.

RUÍZ ASENCIO, José Manuel, "Los copistas del Liber Testamentorum", in Liber Testamentorum coenobii laurbanensis, (dir. de José FERNÁNDEZ CATÓN), volume de estudos, Léon, Centro de Estudios e Investigación «San Isidoro», Caja España de inversiones, Archivo Histórico Diocesano, 2008, pp. 193-242.

RUIZ, Elisa, Manual de Codicologia, Madrid, Fundación Germán Sánchez Ruiperez, 1988.

SILVA, José Custódio Vieira da, "A iluminura medieval / algumas reflexões", in $A$ iluminura em Portugal. Identidade e Influências, catálogo de exposição bibliográfica (comissariado científico e geral de Maria Adelaide MIRANDA), Lisboa, Ministério da Cultura - Biblioteca Nacional, 1999, pp. 39-48.

STIERLIN, Henri, Le livre de Feu. L'apocalypse et l'art mozarabe, Paris, Bibliothèque des arts, 1978.

IDEM, Los Beatus de Liébana y el arte mozárabe, Madrid, Editora Nacional, 1983. THOMAS, Jacques, La Divine Porportion \& l'art de la géométrie - Études de symbolique chrétienne, Paris, Archè Edidit, 1993.

WILLIAMS, John, "22. The Lorvão Beatus (L)", in John WILLIAMS, The illustrated Beatus. A corpus of the illustrations of the Commentary on the Apocalypse, vol. V (The 12th and 13th Centuries), Londres, Harvey Miller Publishers, 1994, pp. 31-34.

IDEM, "Beatus of Liébana", in John WILLIAMS, The illustrated Beatus. A corpus of the illustrations of the Commentary on the Apocalypse, vol. I, Londres, Harvey Miller Publishers, 1994, pp. 13-17.

IDEM, "Le Commentaire illustré", in Los Beatos, catálogo de exposição bibliográfica, (comissariado científico e geral de Peter COCKSHAW), Chapelle de Nassau, Bibliothéque Royal Albert I, 1985, pp.19-21.

IDEM, "Purpose and imagery in the Apocalypse Commentary of Beatus of Liébana" The Apocalypse in the Middle Ages, (dir. de Richard K. EMMERSON e Bernard MCGINN), Ithaca, Cornell University Press, 1992, pp. 217-233.

IDEM, "The Beatus Text", in John WILLIAMS, The illustrated Beatus. A corpus of the illustrations of the Commentary on the Apocalypse, vol. I, Londres, Harvey Miller Publishers, 1994, pp. 19-29.

IDEM, "The Commentary and Islamic Art", in John WILLIAMS, The illustrated Beatus. A corpus of the illustrations of the Commentary on the Apocalypse, vol. I, 
Ana de Oliveira DiAs, Commentarium in Apocalypsin: o número e a forma geométrica na tradição simbólica das ilustrações do «Beato» de São Mamede de Lorvão

Londres, Harvey Miller Publishers, 1994, pp. 143-157.

IDEM, The illustrated Beatus. A corpus of the illustrations of the Commentary on the Apocalypse, V vols., Londres, Harvey Miller Publishers, 1994.

IDEM, "The Illustrated Commentary", in John WILLIAMS, The illustrated Beatus. A corpus of the illustrations of the Commentary on the Apocalypse, vol. I, Londres, Harvey Miller Publishers, 1994, pp. 31-101.

IDEM, "The uses of the Commentary and its Imagery", in John WILLIAMS, The illustrated Beatus. A corpus of the illustrations of the Commentary on the Apocalypse, vol. I, Londres, Harvey Miller Publishers, 1994, pp. 103-141.

WOOLFRANDEN, Graham, Daily prayer in Christian Spain - a study of the mozarabic office, Londres, SPCK, 2000.

VÁZQUEZ DE PARGA, Luis, "Beatus de Liébana et «Los Beatos»", in Los Beatos, catálogo de exposição bibliográfica (comissariado científico e geral de Peter COCKSHAW), Chapelle de Nassau, Bibliothéque Royal I ${ }^{\text {er }}$, 1985, pp. 3-8.

VÁZQUEZ DE PARGA, Luis, "Beato y el ambiente cultural de su época", in Actas del Simposio para el estudio de los códices del'Comentario al Apocalipsis de Beato de Liébana, vol. I, Madrid, Joyas Bibliográficas, 1978, pp. 35-45.

VIGUERA MOLINS, María Jesús, «Existe una identidad mozárabe?» A modo de conclusión, in Existe una identidad mozárabe? Historia, lengua y cultura de los cristianos de al-Andalus (siglos IX-XII), (dir. de Cyrille AILLET), Madrid, Casa de Velázquez, 2008, pp. 299 -314. 